\title{
EFEITOS CEFALOMÉTRICOS DO APARELHO EXTRABUCAL CONJUGADO (SPLINT MAXILAR) E DO BIONATOR, NO TRATAMENTO DA MÁ OCLUSÃO DE CLASSE II, $1^{\text {a }}$ DIVISÃO
}

\section{RENATA RODRIGUES DE ALMEIDA-PEDRIN}

Tese apresentada à Faculdade de Odontologia de Bauru, da Universidade de São Paulo, como parte dos requisitos para obtenção do título de Doutor em Odontologia, área de Ortodontia.

(Edição Revisada)

BAURU

2003 


\section{EFEITOS CEFALOMÉTRICOS DO APARELHO EXTRABUCAL CONJUGADO (SPLINT MAXILAR) E DO BIONATOR, NO TRATAMENTO DA MÁ OCLUSÃO DE CLASSE II, $1^{\text {a }}$ DIVISÃO}

\section{RENATA RODRIGUES DE ALMEIDA-PEDRIN}

Tese apresentada à Faculdade de Odontologia de Bauru, da Universidade de São Paulo, como parte dos requisitos para obtenção do título de Doutor em Odontologia, área de Ortodontia.

(Edição Revisada)

Orientador: Prof. Dr. Arnaldo Pinzan

BAURU

2003 


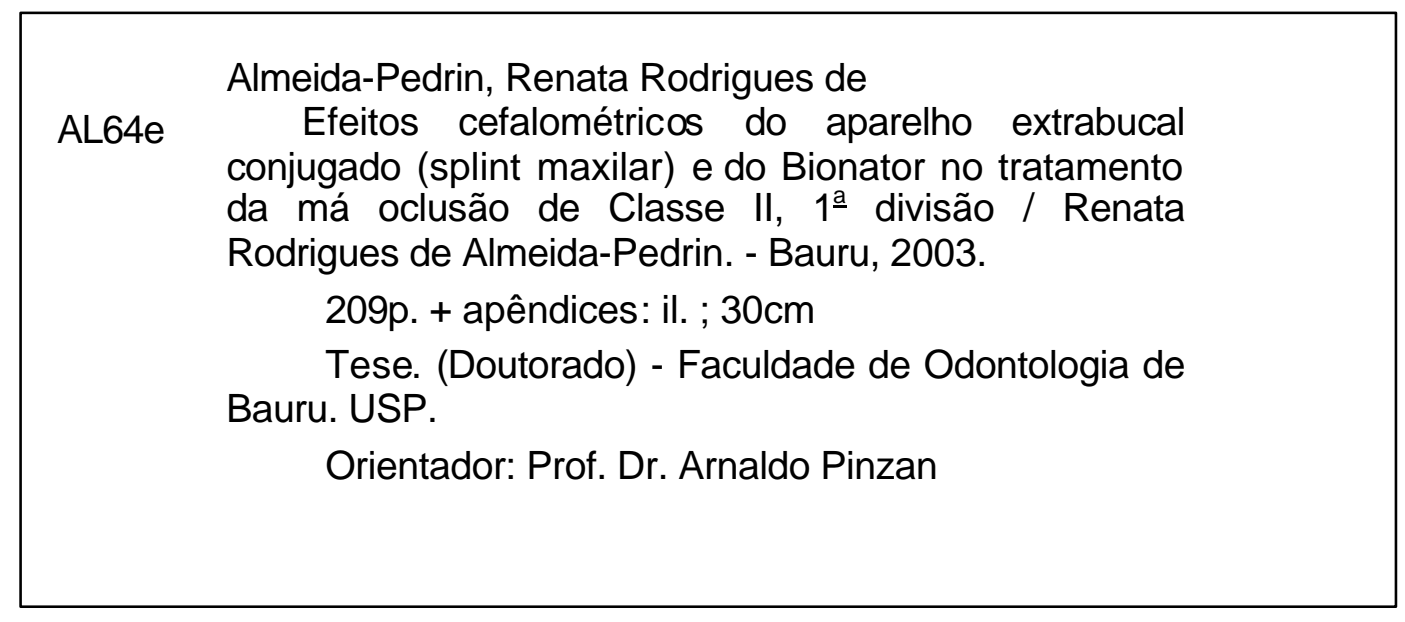
Autorizo, exclusivamente para fins acadêmicos e científicos, a reprodução total ou parcial desta tese, por processos fotocopiadores e outros meios eletrônicos.

Assinatura do autor (a):

Data: 


\section{RENATA RODRIGUES DE ALMEIDA-PEDRIN}

17 de dezembro de 1973

Bauru - SP

1992-1995

1996

1996

1998-1999

2001

Associações
Nascimento

Curso de Odontologia na Faculdade de Odontologia de Lins.

Professora Assistente da Faculdade de Odontologia de Lins, Disciplina de Ortodontia.

Curso de Especialização em Radiologia, na Faculdade de Odontologia de Bauru da Universidade de São Paulo.

Curso de Pós-Graduação em Ortodontia, ao nível de Mestrado, na Faculdade de Odontologia de Bauru da Universidade de São Paulo.

Curso de Pós-Graduação em Ortodontia, ao nível de Doutorado, na Faculdade de Odontologia de Bauru da Universidade de São Paulo.

ABOR - Associação Brasileira de

Ortodontia e Ortopedia Facial

APEO - Associação Paulista de Especialistas em Ortodontia e Ortopedia Facial 


\section{A Deus}

Vós que estivestes ao men lado a cada passo desta jornada; nada daría tão certo se não fosse por TiSenhor; por isso sempre pronuncio:

"O Senhor é meu pastor e nada me faltará.

Emverdes pastos me faz repousar, conduz-me até às fontes tranqüilas e reanima minha vida.

Guia-me pelas veredas da justiça por causa do Seu nome. Ainda que ew andasse por um vale tenebroso, não temeria mal algum, porque Tw estás comigo;

O Teubordão e Teu cajado me confortam.

Diante de mimpreparas a mesa, bem à vista dos mens inimigos, unges minha cabeça com óleo,

e men cálice transborda.

Certamente, que a bondade e a misericórdia me seguirão todos os dias de minha vida; e habitarei na casa do Senhor por longos dias."

Salmo 23

Obrigada men DEUS 


\section{Dedicatóría}

À minha maravithosa familia,

"Se você tem uma familia, não precisa inventar outra: é só escrever sobre ela."

Thomas Mann

À minha amada fitha,

Rafacla, que desde já, faz transbordar nossos coraçóes de alegria e modifica o sentido de nossas vidas.

Ao mew querido marido,

Fernando, pelo companheirismo, afeto e atenção que sempre dispensou a mim e por estar sempre ao men lado em todos os momentos.

Aos mensqueridos pais,

Renato e Odete, que me deram a vida e me ensinaram a vivê-la com dignidade, exemplos de infinita doação de amor, que 
direcionaram todos os mens caminhos, oferecendo-me carinho e compreensão durante mais esta etapa de minha vida.

Ao meuquerido irmão e sua familia,

Marcio, por ser meu guru na árdua tarefa de pesquisadora, orientando e incentivando-me sempre.

À minha cunhada Paty e minhas sobrinhas Marcella e Mariana pelo carinho ealegria contagiante.

Aos mens queridos tios, avós e primos,

À minha tia Celina que me ensinow e acompanhou com paciência, carinho e dedicação os primeiros passos na Ortodontia e continua brindando-me com sua companhia diariamente. Ao meu tio Junior e mens primos Natália e Marcelo pela prazerosa convivência

Aos mens avós Generoso e Benita, mens tios Fátima e José Américo e minha mais nova prima Maria Eduarda que me mesmo um pouco distantes me incentivame alegram minha vida.

A todos vocês, com amor, dedico este trabalho. 
Agradecimento Especial,

Ao meu pai e professor Dr. Renato-Rodrigues de Almeida, exemplo de humildade e dedicação, que além de transmitir seus conhecimentos na Ortodontia contribuindo para o aprimoramento de minha formação docente, sempre esteve presente nos momentos de decisão aconselhando e orientando-me a galgar degraus mais altos na minha formação pessoal $e$ profissionat.

A minha eterna gratidão. 
Agradecimento Especiat,

Ao mew irmão Marcio, pela incansável ajuda, imenso carinho e paciência dispensada na elaboração desta pesquisa. A sua perseverança e garra em buscar constantemente a perfeição e novor desafios nesta carreira o fazem um grandioso pesquisador.

A sinceridade de minha gratidão 
Agradecimento Especial,

Ao inestimável mestre Professor Dr. Arnaldo Pinzan, eximio orientador desta pesquisa, pela compreensão, incentivo, paciência e confiança em mim depositada e também à sua esposa tia Célia e suas fithas em especial a Celinha que me brindam com uma amizade sincera.

Minha admiração e meu reconhecimento 


\section{Agradecimentos}

Aos Professores Doutores e suas respectivas familias, Décio Rodrigues Martins, Guitherme dos Reis Pereira Janson, José Fernando Castanha Henriques e Marcos Roberto de Freitas, pelos ensinamentos criteriosos transmitidos, pela minha formação docente na ciência ortodôntica e pela amizade e apoio constante durante todos estes anos de convívio.

Ao Diretor da Faculdade de Odontologia de Lins UNIMEP, Professor Doutor Carlos Werner, por ter acreditado na minha formação docente e possibilitado a concretização deste ideal.

À Professora Doutora María Fidela de Líma Navarro Diretora da Faculdade de Odontologia de Bauru e ao Professor Doutor José Carlos Pereira, Presidente da Comissão de Pós-Graduação da Faculdade de Odontologia de Baurw, pela oportunidade que me foi concedida. 
Ao Professor Doutor José Fernando Castanha Henriques, Coordenador do Curso de Pós-Graduação em Ortodontia, ao nivel de Doutorado pelos conhecimentos transmitidos e pela cessão da amostra utilizada neste trabalho.

A todos os familiares do mew marido Fernando que de forma direta ou indireta contribuiram para minha formação, em especial meu sogro Sr. Ney e minha sogra Dona Cleuza que sempre se preocuparam em me proporcionar momentos alegres e gratificantes, incentivando-me mais uma vez nesta etapa e ajudando-me a concretizar este sonho.

À amiga Maria Helena Ferreira Vasconcelos, pela amizade e companheirismo nas muitas horas de convívio e trabalho diário. 
Aos amigos Dani e Danito pela sinceridade de suas amizades em todos esses anos de convivência, pela paciência, carinho e atenção a mim dedicada durante todo o curso de graduação e de pós.

Às amigas Claudia e Tatiana, que me acompanham desde a adolescência, e continuam presentes sem deixar que as barreiras da vida dispersem nossa amizade.

Aos amigos do Curso de Doutorado, Adriano, Ana Carla, Ana Cláudia, Daniela, Fausto, Karina, Karyna e Paulo, , pela estima e colaboração durante o curso e aos "agregados" César, Continho, Alemão, Veridiana, Mauro e Vanessa pelos prazerosos momentos de convívio durante todos estes anos.

Aos amigos mineirinhos José Norberto e Tatiana que mesmo distantes me auxitiaram nesta jornada e me incentivam ofertando sua amizade. 
Aos alunos do CORA e do Curso de Especialização em Ortodontia da Faculdade de Odontologia de LinsUNIMEP, pelo reconhecimento como amiga e professora.

Aos Colegas das turmas de Mestrado, Adriana, Célia, Claudia, Daniele, Denise, Fábio, Fabricio, Fernanda, José Eduardo, Karina, Maria Fernanda, Rejane, Sandra, Anatu, Ângela, Celso, Cristina, Daniela, Karina, Leniana e Rodrigo, pela amizade e convívio no departamento.

Aos Funcionários da Disciplina de Ortodontia, Sérgio, Tía Maria, Cristina e em especial à Verinha, que sempre me acotheram e me ajudaram dispensando atenção, carinho e amizade. E ao Daniel que auxiliou, sempreque preciso, com a informática.

Aos funcionários da biblioteca, especialmente à Rita, Vera e à Valéria, pelas constantes orientações e pelo zelo nos serviços prestados. 
Aos funcionários da Pós-Graduação Giane, Margareth, Graciane e Jefferson pela constante cordialidade.

Às funcionárias do CORA, Élida, Cléo, Regiane e Viviane pela presteza em tornar nosso dia-a-dia mais agradável.

À CAPES pela concessão da bolsa de estudo. 
SUMÁRIO 


\section{SUMÁRIO}

LISTA DE FIGURAS …………………………….................................. XVI

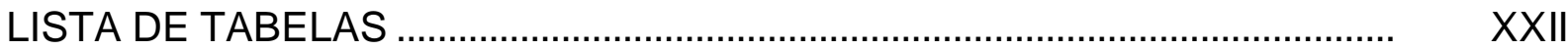

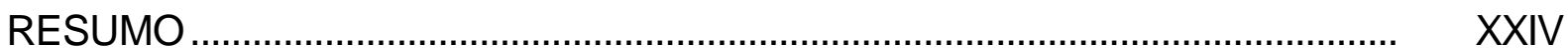

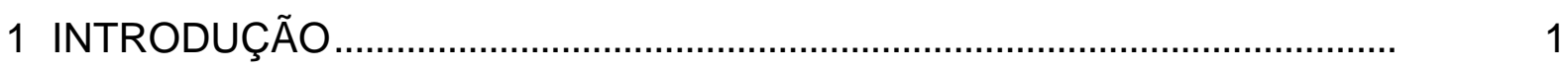

2 REVISÃO DE LITERATURA …………………………................................

2.1 Características da má oclusão de Classe II, 1ㄹ divisão............................................. 6

2.2 Tratamento da má oclusão de Classe II, $1^{\underline{a}}$ divisão com o aparelho extrabucal conjugado (splint maxilar)............................................................................ 25

2.3 Tratamento da má oclusão de Classe II, 1를 divisão com o Bionator........................ 37

3 PROPOSIÇÃO

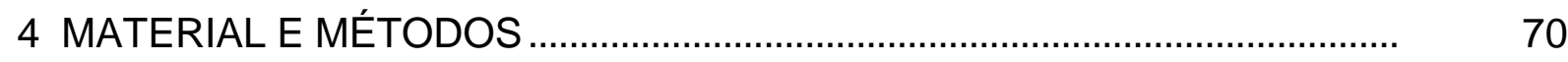

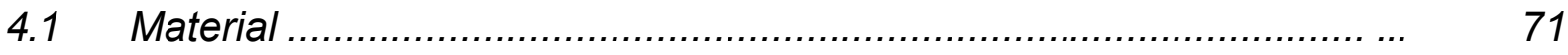

4.1.1 Obtenção da amostra ....................................................................

4.1.2 Descrição dos aparelhos utilizados nos grupos experimentais........................ 73

4.1.2.1 Aparelho extrabucal conjugado................................................................

4.1.2.2 Aparelho do tipo Bionator.........................................................................

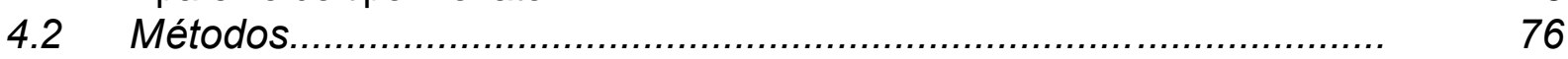

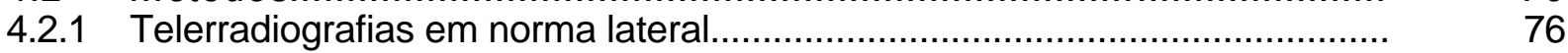

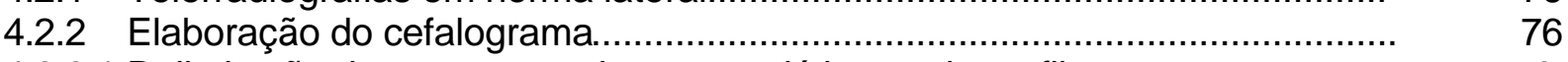

4.2.2.1 Delimitação das estruturas dentoesqueléticas e do perfil tegumentar.............. 78

4.2.2.2 Demarcação dos pontos cefalométricos de referência.................................... $\quad 80$

4.2.2.3 Planos e linhas de referência..................................................................... 84

4.2.2.4 Mensuração das grandezas angulares e lineares...................................... 87

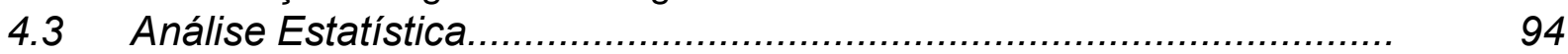

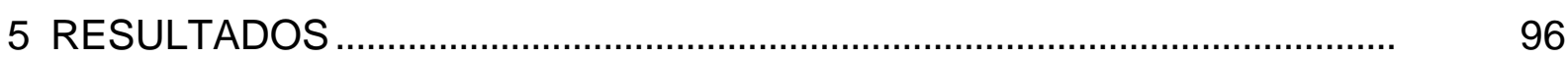

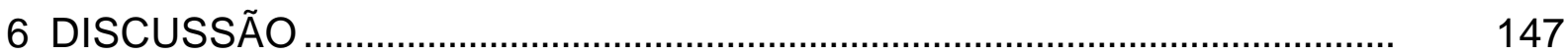

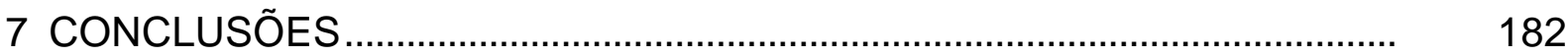

REFERÊNCIAS BIBLIOGRÁFICAS ................................................................. 186

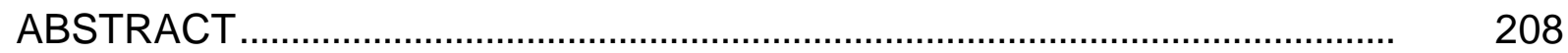




\section{LISTA DE FIGURAS}

FIGURA A- AEB conjugado - vista oclusal superior $\quad 74$

FIGURA B- Paciente com o aparelho (AEB conjugado) 74

FIGURA C- Bionator de Balters modificado (ASCHER) 75

FIGURA 1- Desenho anatômico das estruturas dentoesqueléticas e do perfil tegumentar 79

FIGURA 2- Pontos cefalométricos utilizados 83

FIGURA 3- Planos e linhas de referência 86

FIGURA 4- Grandezas angulares $\quad 89$

FIGURA 5- Grandezas lineares esqueléticas $\quad 91$

FIGURA 6- Grandezas lineares dentárias e tegumentares 93

FIGURA 7- Valores médios iniciais e finais para os três grupos da $\begin{array}{ll}\text { grandeza Co-Gn } & 107\end{array}$

FIGURA 8- Valores médios iniciais e finais para os três grupos da grandeza Go-Gn 107

FIGURA 9- Valores médios iniciais e finais para os três grupos da $\begin{array}{ll}\text { grandeza SN.GoGn } & 108\end{array}$

FIGURA 10- Valores médios iniciais e finais para os três grupos da $\begin{array}{ll}\text { grandeza SN.PP } & 108\end{array}$

FIGURA 11- Valores médios iniciais e finais para os três grupos da grandeza AFAI

FIGURA 12- Valores médios iniciais e finais para os três grupos da grandeza S-Go

FIGURA 13- Valores médios iniciais e finais para os três grupos da grandeza 6-PP

FIGURA 14- Valores médios iniciais e finais para os três grupos da grandeza ANL 
FIGURA 15- Valores médios iniciais e finais da grandeza SNA para os grupos 1 e 2

FIGURA 16- Valores médios iniciais e finais da grandeza Nperp-A para os grupos 1 e 2

FIGURA 17- Valores médios iniciais e finais da grandeza Co-A para os grupos 1 e 2

FIGURA 18- Valores médios iniciais e finais da grandeza SNA para os grupos 1 e 3

FIGURA 19- Valores médios iniciais e finais da grandeza Nperp-A para os grupos 1 e 3

FIGURA 20- Valores médios iniciais e finais da grandeza Co-A para os grupos 1 e 3

FIGURA 21- Valores médios iniciais e finais da grandeza SNA para os grupos 2 e 3

FIGURA 22- Valores médios iniciais e finais da grandeza Nperp-A para os grupos 2 e 3

FIGURA 23- Valores médios iniciais e finais da grandeza Co-A para os grupos 2 e 3

FIGURA 24- Valores médios iniciais e finais da grandeza SNB para os grupos 1 e 2

FIGURA 25- Valores médios iniciais e finais da grandeza Nperp-P para os grupos 1 e 2

FIGURA 26- Valores médios iniciais e finais da grandeza SNB para os grupos 1 e 3

FIGURA 27- Valores médios iniciais e fnais da grandeza Nperp-P para os grupos 1 e 3

FIGURA 28- Valores médios iniciais e finais da grandeza SNB para os grupos 2 e 3

FIGURA 29- Valores médios iniciais e finais da grandeza Nperp-P para os grupos 2 e 3 
FIGURA 30- Valores médios iniciais e finais da grandeza ANB para os grupos 1 e 2

FIGURA 31- Valores médios iniciais e finais da grandeza NAP para os grupos 1 e 2

FIGURA 32- Valores médios iniciais e finais da grandeza ANB para os grupos 1 e 3

FIGURA 33- Valores médios iniciais e finais da grandeza NAP para os grupos 1 e 3

FIGURA 34- Valores médios iniciais e finais da grandeza ANB para os grupos 2 e 3

FIGURA 35- Valores médios iniciais e finais da grandeza NAP para os grupos 2 e 3

FIGURA 36- Valores médios iniciais e finais da grandeza 1.NA para os grupos 1 e 2

FIGURA 37- Valores médios iniciais e finais da grandeza 1-NA para os grupos 1 e 2

FIGURA 38- Valores médios iniciais e finais da grandeza $\underline{6}-\mathrm{FHp}$ para os grupos 1 e 2

FIGURA 39- Valores médios iniciais e finais da grandeza 1.NA para os grupos 1 e 3

FIGURA 40- Valores médios iniciais e finais da grandeza 1-NA para os grupos 1 e 3

FIGURA 41- Valores médios iniciais e finais da grandeza $\underline{6}-\mathrm{FHp}$ para os grupos 1 e 3

FIGURA 42- Valores médios iniciais e finais da grandeza 1.NA para os grupos 2 e 3

FIGURA 43- Valores médios iniciais e finais da grandeza 1-NA para os grupos 2 e 3

FIGURA 44- Valores médios iniciais e finais da grandeza $\underline{6}-\mathrm{FHp}$ para os grupos 2 e 3 
FIGURA 45- Valores médios iniciais e finais da grandeza $\overline{1}$.NB para os grupos 1 e 2

FIGURA 46- Valores médios iniciais e finais da grandeza IMPA para os grupos 1 e 2

FIGURA 47- Valores médios iniciais e finais da grandeza 1 .NB para os grupos 1 e 3

FIGURA 48- Valores médios iniciais e finais da grandeza IMPA para os grupos 1 e 3

FIGURA 49- Valores médios iniciais e finais da grandeza $\overline{1}$.NB para os grupos 2 e 3

FIGURA 50- Valores médios iniciais e finais da grandeza IMPA para os grupos 2 e 3

FIGURA 51- Valores médios iniciais e finais da grandeza 1-NB para os grupos 1 e 2

FIGURA 52- Valores médios iniciais e finais da grandeza $\overline{6}-\mathrm{FHp}$ para os grupos 1 e 2

FIGURA 53- Valores médios iniciais e finais da grandeza $\overline{6}$-GoMe para os grupos 1 e 2

FIGURA 54- Valores médios iniciais e finais da grandeza i-NB para os grupos 1 e 3

FIGURA 55- Valores médios iniciais e finais da grandeza $\overline{6}-\mathrm{FHp}$ para os grupos 1 e 3

FIGURA 56- Valores médios iniciais e finais da grandeza $\overline{6}$-GoMe para os grupos 1 e 3

FIGURA 57- Valores médios iniciais e finais da grandeza 1 -NB para os grupos 2 e 3

FIGURA 58- Valores médios iniciais e finais da grandeza $\overline{6}-\mathrm{FHp}$ para os grupos 2 e 3 
FIGURA 59- Valores médios iniciais e finais da grandeza $\overline{6}$-GoMe para os grupos 2 e 3

FIGURA 60- Valores médios iniciais e finais da grandeza Ls-Pog'Sn para os grupos 1 e 2

FIGURA 61- Valores médios iniciais e finais da grandeza Ls-Pog'Sn para os grupos 1 e 3

FIGURA 62- Valores médios iniciais e finais da grandeza Ls-Pog'Sn para os grupos 2 e 3

FIGURA 63- Valores médios iniciais e finais da grandeza Li-Pog'Sn para os grupos 1 e 2

FIGURA 64- Valores médios iniciais e finais da grandeza Li-Pog'Sn para os grupos 1 e 3

FIGURA 65- Valores médios iniciais e finais da grandeza Li-Pog'Sn para os grupos 2 e 3

FIGURA 66- Alterações do ângulo SNA nos três grupos

FIGURA 67- Alterações da medida Nperp-A nos três grupos

FIGURA 68- Alterações do comprimento efetivo da maxila Co-A nos três grupos

FIGURA 69 Alterações do ângulo SNB nos três grupos

FIGURA 70 Alterações da medida Nperp nos três grupos 158

FIGURA 71- Alterações da medida Go-Gn nos três grupos

FIGURA 72- Alterações do comprimento efetivo da mandíbula (Co-Gn) nos três grupos

FIGURA 73- Alterações do ângulo ANB nos três grupos 
FIGURA 75- Alterações do ângulo SN.GoGn nos três grupos

FIGURA 76- Alterações do ângulo SN.PP nos três grupos

FIGURA 77- Alterações da altura facial ântero-inferior (AFAl) nos três grupos

FIGURA 78- Alterações da altura facial posterior (S-Go) nos três grupos 166

FIGURA 79- Alterações do ângulo 1.NA nos três grupos 168

FIGURA 80- Alterações da medida 1-NA nos três grupos 169

FIGURA 81- Alterações da medida 6-PP nos três grupos 170

FIGURA 82- $\quad$ Alterações da medida $\underline{6}-\mathrm{FHp}$ nos três grupos 170

FIGURA 83- Alterações do ângulo 1.NB nos três grupos 172

FIGURA 84- Alterações da medida 1̄-NB nos três grupos 172

FIGURA 85- Alterações do ângulo IMPA nos três grupos 173

FIGURA 86- Alterações da medida $\overline{6}$-GoMe nos três grupos 173

FIGURA 87- Alterações da medida $\overline{6}$-FHp nos três grupos

FIGURA 88- Alterações do lábio superior (Ls-Pog'Sn) nos três grupos

FIGURA 89- Alterações do lábio inferior (Li-Pog'Sn) nos três grupos

FIGURA 90- Alterações do ângulo nasolabial nos três grupos 


\section{LISTA DE TABELAS}

TABELA 1- Média das idades iniciais e finais dos jovens nos 3 grupos e o tempo médio de avaliação

TABELA 2- $\quad$ Análise de Variância (ANOVA) entre as médias das idades iniciais e finais dos jovens nos 3 grupos e do tempo médio de avaliação

TABELA 3- Cálculo do erro do método intra-examinador. Diferença entre a primeira e a segunda mensuração (milímetros ou graus), desvio-padrão das medidas, erro casual (Dahlberg) e erro sistemático (teste "t”)

TABELA 4- Análise de Variância (ANOVA) entre os 3 grupos dos valores médios das medidas iniciais

TABELA 5- Teste de Tukey entre os grupos 1 e 2 para comparação das medidas iniciais das variáveis estatisticamente significantes verificadas pela análise de variância.

TABELA 6- Teste de Tukey entre os grupos 1 e 3 para comparação das medidas iniciais das variáveis estatisticamente significantes verificadas pela análise de variância.

TABELA 7- Teste de Tukey entre os grupos 2 e 3 para comparação das medidas iniciais das variáveis estatisticamente significantes verificadas pela análise de variância.

TABELA 8- Análise de Variância (ANOVA) entre os 3 grupos das diferenças das médias das alterações iniciais e finais

TABELA 9- Comparação das médias das alterações entre os grupos 1 e 2 
utilizando o teste de Tukey para as grandezas estatisticamente significantes verificadas pela análise de variância

TABELA 10- Comparação das médias das alterações entre os grupos 1 e 3 utilizando o teste de Tukey para as grandezas estatisticamente significantes verificadas pela análise de variância

TABELA 11- Comparação das médias das alterações entre os grupos 2 e 3 utilizando o teste de Tukey para as grandezas estatisticamente significantes verificadas pela análise de variância 


\section{RESUMO}




\section{RESUMO}

Este estudo cefalométrico objetivou avaliar as alterações dentárias, esqueléticas e tegumentares, em jovens com má oclusão de Classe II, 1a divisão, tratados com o aparelho extrabucal conjugado (splint maxilar) e com o Bionator. Estes dois grupos experimentais foram comparados a um grupo de jovens portadores da mesma má oclusão que não receberam tratamento, pareados pelo gênero, idade, tempo de observação e grandezas cefalométricas iniciais. A amostra constou de 180 telerradiografias em norma lateral de 90 jovens, divididos em três grupos de 30 , sendo 15 do gênero masculino e 15 do feminino. Os jovens do grupo 1 foram mantidos como controle e apresentaram uma idade inicial média de 10,02 anos e foram observados pelo período médio de 1,49 anos. O grupo 2, foi submetido ao tratamento utilizando o aparelho extrabucal conjugado (splint maxilar), com idade inicial média de 10,02 anos e tempo de observação de 1,78 anos. O grupo 3 , foi tratado com o Bionator por um tempo médio de 1,52 anos e os jovens apresentavam idade inicial média de 10,35 anos. A comparação entre as variáveis cefalométricas iniciais evidenciou grande similaridade entre os três grupos possibilitando comparações diretas entre eles. A análise dos resultados mostrou que o tratamento da má oclusão de Classe II, 1a divisão com o AEB conjugado e com o Bionator resultou de efeitos específicos e inerentes a cada aparelho. Os resultados patentearam que o deslocamento anterior da maxila foi restringido significantemente pelo tratamento com o AEB conjugado. O Bionator promoveu um aumento significante na protrusão mandibular, enquanto que o AEB conjugado mostrou efeitos esqueléticos menos evidentes. No entanto, ambos os aparelhos estudados produziram um aumento nos comprimentos efetivo e do corpo da mandíbula, com valores maiores para o grupo 2. A relação maxilomandibular melhorou significantemente nos grupos tratados em comparação ao grupo controle. A análise do padrão de crescimento craniofacial e das alturas faciais não revelou alteração significante entre os grupos. Em relação às alterações dentoalveolares ambos aparelhos provocaram inclinação para lingual e retrusão dos incisivos superiores, porém os efeitos do AEB conjugado foram significantemente mais intensos. Os incisivos inferiores foram afetados de maneira distinta pelos aparelhos. No grupo 
tratado com o AEB conjugado, os incisivos lingualizaram e retruíram enquanto que o grupo tratado com o Bionator apresentou inclinação para vestibular e protrusão destes dentes. Os molares inferiores apresentaram um maior desenvolvimento vertical e horizontal nos grupos 2 e 3 . Os primeiros molares superiores distalizaram no grupo tratado com o AEB conjugado enquanto nos grupos 3 (Bionator) e controle houve mesialização. Em relação ao perfil tegumentar constatou-se que o ângulo nasolabial não foi afetado pelo tratamento. Os referidos aparelhos promoveram uma retrusão do lábio superior. Observou-se uma protrusão do lábio inferior no grupo tratado com o Bionator e retrusão desta estrutura com o emprego do AEB conjugado. Deste modo, verificou-se que ambos os protocolos de tratamento propiciaram alterações esqueléticas, dentárias e tegumentares, distintas e clinicamente relevantes para a correção da má oclusão de Classe II, 1a divisão. 
1 INTRODUÇÃO 


\section{INTRODUÇÃO}

A má oclusão de Classe II foi definida por ANGLE $^{13}$ como uma relação mesiodistal deficiente dos arcos dentários, com todos os dentes inferiores ocluindo distalmente em relação ao padrão normal, propiciando uma desarmonia acentuada na região dos incisivos e nas linhas faciais. No entanto, esta classificação baseavase essencialmente nas posições dentoclusais e não considerava as discrepâncias nos sentidos vertical, horizontal e transversal, e nem as relacionava com as estruturas esqueléticas adjacentes.

Atualmente, sabe-se que a má oclusão de Classe II tem um envolvimento das bases ósseas no sentido sagital, vertical e transversal, caracterizada, morfologicamente, por uma discrepância maxilomandibular, por um mau relacionamento dos arcos superior e inferior, ou por uma combinação destes fatores.

Avaliando as alterações sagitais da Classe II, observa-se que esta pode estar relacionada à presença isolada ou à combinação do prognatismo maxilar, do retrognatismo mandibular, com retrusão dos dentes inferiores e protrusão dos superiores, sendo o retrognatismo mandibular considerado como um dos maiores responsáveis por esta má oclusão ${ }^{107}$. Pode também existir uma combinação destes fatores com um excesso vertical da maxila ou uma deficiência transversal desta base óssea, denotando a presença de alterações nos três planos: horizontal, vertical e transversal. Esta má oclusão pode também estar acompanhada de uma função anormal dos lábios e de alguma forma de obstrução nasal e respiração bucal ${ }^{14}$.

A má oclusão de Classe II pode comprometer a harmonia facial em diversos graus, de acordo com a intensidade da sobressaliência (overjet) dentária e de sua interação com as estruturas adjacentes de tecidos moles, interferindo na imagem e auto-estima do paciente ${ }^{105,157}$, assim, o tratamento desta má oclusão é importante para a ressocialização do paciente e de grande interesse para os ortodontistas sendo que a demanda pelo tratamento é significante na clínica ortodôntica uma vez que esta má oclusão representa o maior percentual nas clínicas ortodônticas de todo o mundo alcançando índices de $55 \%{ }^{59}$. 
O protocolo de tratamento da Classe II depende da idade do paciente, do comprometimento estético e oclusal. A interceptação da má oclusão de Classe II constitui um dos assuntos mais estudados e controversos da Ortodontia Contemporânea, em função dos diferentes tipos de aparelhos disponíveis e da época ideal para o início do tratamento, destacando-se o tratamento em uma única fase (aparelhos fixos) e em duas fases (aparelhos ortopédicos e fixos). Os aparelhos ortopédicos visam corrigir a discrepância maxilomandibular nos sentidos ânteroposterior e transversal, contribuindo para uma melhora na relação das bases apicais, uma oclusão com estabilidade e harmonia do perfil facial. No entanto, o tratamento com aparelhos ortopédicos deve ser indicado para jovens em fase de crescimento e desenvolvimento craniofacial, com a finalidade de alterar espacialmente a forma e o posicionamento das bases ósseas, redirecionando o crescimento da maxila $e$ liberando o da mandíbula, gerando uma nova situação mais estável e equilibrada.

Muitos estudos 3,4,5,37,38,41,61,75,112,115,128,157,163 compararam os efeitos de aparelhos ortopédicos funcionais como o Bionator, o Fränkel, o Herbst e os ativadores, na correção da má oclusão de Classe II, 1a divisão. Porém há poucos trabalhos 45,88,105,164 comparando as alterações promovidas por aparelhos ortopédicos mecânicos como o AEB (aparelho extrabucal) ou AEB conjugado (splint maxilar) com aparelhos ortopédicos funcionais, gerando muita controvérsia em relação ao modo de ação destes aparelhos.

Há um consenso na literatura $3,4,5,41,45,75,88,105,128,157,164$ no que diz respeito à efetividade destes aparelhos na correção da má oclusão de Classe II, 1a divisão sendo que as alterações mais evidentes são o reposicionamento ântero-posterior das bases apicais, melhora da relação molar e redução do overjet. Entretanto, existe uma polêmica em relação ao mecanismo de ação destes aparelhos no sentido ântero-posterior. O efeito mais evidente e de maior consenso entre os pesquisadores é a restrição do crescimento anterior da maxila promovida pelo AEB 6,8,33,56,67,69,70,100,105,145,148,156. Alguns estudos 45,64,77,94,121,123,147,150,151,160 indicam que os ativadores também inibem o deslocamento anterior da maxila, mas todos concordam que o AEB é mais efetivo. O efeito destes aparelhos no posicionamento 
mandibular é um ponto mais controverso sendo que muitos estudos $19,20,25,27,36,41,44,45,57,60,61,71,77,78,79,88,94,101,105,109,111,119,144,147,150,153,154$ mostraram efeitos positivos na mandíbula com o uso de ativadores e até mesmo com o AEB $18,56,67,68,70,88,100,105,145,156$, e outras pesquisas 33,64,65,115,121,160 não verificaram influência destes aparelhos na base apical inferior, no entanto, a controvérsia ainda existe. E a questão polêmica permanece sem resposta definida. Será que os aparelhos ortopédicos, sejam eles mecânicos ou funcionais, produzem alterações significantes no crescimento mandibular?

Outra questão relevante envolve as alterações dentárias decorrentes da utilização destes aparelhos ortopédicos, principalmente no sentido vertical, pois poucos estudos randômicos avaliaram tais efeitos ${ }^{88}$. A distalização dos molares superiores com o uso do AEB é ponto pacífico entre os pesquisadores; o mesmo não se pode extrapolar para os aparelhos funcionais, ocorrendo muita discórdia. Por outro lado, existe uma dicotomia de opinião, referente ao posicionamento destes dentes no sentido vertical e em relação aos efeitos sobre os incisivos.

Ainda hoje, a literatura ortodôntica mostra-se controversa quanto aos efeitos esqueléticos e dentários decorrentes dos aparelhos ortopédicos. Conseqüentemente às alterações dentoesqueléticas, seriam os aparelhos ortopédicos capazes de melhorar significantemente o perfil facial do paciente?

Diante destas considerações e à luz das divergências dos resultados, 0 objetivo deste trabalho consistiu em avaliar comparativamente os efeitos dentários, esqueléticos e tegumentares decorrentes do tratamento da má oclusão de Classe II, $1^{\text {a }}$ divisão com o AEB conjugado (splint maxilar) e com o Bionator, uma vez que a literatura compulsada denota poucos estudos comparativos realizados com uma metodologia acurada, na qual se utilizam grupos semelhantes e pareados, tratados com aparelhos ortopédicos mecânico e funcional e grupo de jovens que não receberam nenhum tipo de tratamento (grupo controle). 
2 REVISÃO DE LITERATURA 


\section{REVISÃO DE LITERATURA}

A revisão de literatura discorre uma perspectiva histórica sobre os estudos concernentes à má oclusão de Classe II, destacando os seguintes tópicos:

2.1 Características da má oclusão de Classe II, 1a divisão;

2.2 Tratamento da má oclusão de Classe II, 1a divisão com o Aparelho extrabucal conjugado (splint maxilar);

2.3 Tratamento da má oclusão de Classe II, 1a divisão com o Bionator.

\subsection{CARACTERÍSTICAS DA MÁ OCLUSÃO DE CLASSE II, 1a DIVISÃO}

As más oclusões dentárias apresentam diversas formas de classificação. No entanto, a mais conhecida e utilizada até os dias de hoje, teve como precursor ANGLE $^{13}$. Em 1899, o pai da Ortodontia, publicou na revista Dental Cosmos o primeiro método científico para o diagnóstico e classificação das más oclusões que baseava-se essencialmente nas posições dentoclusais, onde definiu que o primeiro molar superior era imutável em relação ao inferior e a partir daí determinou os três tipos de más oclusões no sentido ântero-posterior. Contudo, apesar de ser muito prática, a classificação de ANGLE $^{13}$ não leva em consideração as discrepâncias nos sentidos vertical, horizontal e transversal, e nem as relaciona com as estruturas esqueléticas adjacentes. Assim, a Classe II, $1^{\text {a }}$ divisão segundo a classificação de Angle foi definida como uma relação mesiodistal deficiente dos arcos dentários, com todos os dentes inferiores ocluindo distalmente em relação ao padrão normal, propiciando uma desarmonia acentuada na região dos incisivos e nas linhas faciais.

Em 1907, o mesmo pesquisador ${ }^{14}$ observou que os casos de Classe I, $1^{a}$ divisão, caracterizavam-se por uma relação distal da mandíbula em relação à maxila e geralmente com tamanho menor. Ele afirmou também que a maxila apresentavase maior que o normal e, freqüentemente atrésica, e os incisivos superiores 
encontravam-se vestibularizados e os inferiores lingualizados. Notou ainda que esta má oclusão geralmente encontrava-se acompanhada de uma função anormal dos lábios e de alguma forma de obstrução nasal e respiração bucal.

Buscando caracterizar a má oclusão de Classe II, HELLMAN ${ }^{66}$ (1922) constatou que a mandíbula encontrava-se subdesenvolvida, assim como a maxila.

LUNDSTRÖM $^{96}$, em 1925, após compulsar a literatura sobre a natureza da Classe II, observou a existência de um padrão esquelético, de origem hereditária, que dificulta o tratamento ortodôntico, e um padrão dentário de fácil tratamento.

Concordando com o relato de HELLMAN ${ }^{66}$, em 1928 OPPENHEIM $^{120}$ observou que na maioria das más oclusões de Classe II, ocorre uma falta de desenvolvimento mandibular. Em seu estudo comparou medidas antropométricas de 18 crânios com características normais e 18 exibindo má oclusão de Classe II. Concluiu que a Classe II não se caracterizava por um excesso de crescimento para anterior da maxila, verificado pelo ponto Próstio, mas que na grande maioria dos casos de distoclusão, este ponto encontra-se posicionado posteriormente. $\mathrm{O}$ autor comentou ainda que o tratamento desta má oclusão deveria consistir no estímulo do crescimento e desenvolvimento mandibular.

ANDERSON ${ }^{11}$, em 1946, apresentou um trabalho onde discutiu diferentes casos clínicos e demonstrou que em muitos deles, a mandíbula apresentava-se bem posicionada e a maxila protruída, gerando uma distoclusão aparente dos molares inferiores e, desta forma, exigindo uma alteração no plano de tratamento.

Em 1948, DRELICH ${ }^{48}$ estudou o padrão facial de 24 jovens com má oclusão de Classe II, $1^{\text {a }}$ divisão e observou que o mento localizava-se mais para posterior, a base do crânio encontrava-se aumentada e o comprimento da mandíbula diminuído. Afirmou ainda que, a maioria da amostra apresentou um desenvolvimento insuficiente da altura facial póstero-inferior resultando em um plano mandibular mais 
inclinado e que os incisivos superiores encontravam-se acentuadamente inclinados para vestibular.

No mesmo ano, estudando uma amostra composta por jovens com más oclusões de Classe I, Classe II, 但 divisão e Classe II, $2^{2}$ divisão, RENFROE ${ }^{129}$, comparou as alterações cefalométricas dos 3 grupos. Por meio de 95 telerradiografias em norma lateral, concluiu que a mandíbula encontrava-se posicionada posteriormente nos jovens com más oclusões de Classe II, $1^{\mathrm{a}}$ e $2^{\underline{a}}$ divisões, porém verificou que o comprimento mandibular apresentava-se similar ao dos jovens com Classe I. Afirmou ainda que o ângulo mandibular denotava um maior aumento nos jovens com Classe I e que a maxila, avaliada pelo ponto ENA encontrava-se protruída nos casos de Classe I e de Classe II, 1a divisão.

NELSON; HIGLEY'16, em 1948, compararam o comprimento do corpo mandibular em 250 jovens dos 7 aos 14 anos de idade, sendo 153 com oclusão normal e má oclusão de Classe I, e 97 jovens com Classe II, 1a divisão. Utilizaram medidas cefalométricas lineares para determinar o comprimento da mandíbula. Após a interpretação das mensurações cefalométricas, os resultados apontaram um menor comprimento do corpo mandibular nos casos de Classe II, 1a divisão.

Objetivando caracterizar a má oclusão de Classe II, 1a divisão, SALZMANN ${ }^{137}$, em 1949 relatou diversas variações desta má oclusão, onde observou maxila protruída, retrusão mandibular e ainda a combinação destes fatores.

No ano seguinte, FISCHER ${ }^{54}$ classificou a má oclusão de Classe II, 1a divisão em três tipos: dentária, dentofacial e facial.

GILMORE $^{62}$, em 1950, avaliou diversas medidas cefalométricas lineares e angulares de 128 pacientes, adultos de ambos os gêneros, sendo 61 com oclusão normal e 67 com má oclusão de Classe II, 1a divisão. Concluiu que as mandíbulas do grupo com Classe II, 1a divisão, apresentavam-se significantemente menores 
com relação ao grupo de oclusão normal; no entanto, não observou alteração significante na posição ântero-posterior da mandíbula, considerando as medidas angulares nos casos de Classe II, $1^{\frac{a}{}}$ divisão.

Com o objetivo de determinar as diferenças existentes entre os padrões esqueléticos faciais da Classe I e da Classe II, 1a divisão, CRAIG ${ }^{40}$, em 1951, comparou um grupo de 34 pacientes Classe I com 12 anos de média de idade, com um grupo de 33 pacientes Classe II, 1a divisão, com média idade de semelhante. Concluiu, por meio de sobreposições, utilizando um sistema gráfico de coordenadas, que ambos os grupos apresentaram um padrão esquelético similar, porém o grupo da Classe II, $1^{a}$ divisão apresentou um menor corpo mandibular, verificado pela distância linear Go-Gn.

Para verificar a posição espacial da maxila e da mandíbula em relação à base do crânio nos diferentes tipos de má oclusão, RIEDEL ${ }^{131}$, em 1952, realizou uma pesquisa com telerradiografias. A amostra constituiurse de 52 adultos com oclusões normais, na faixa etária dos 18 a 36 anos; 24 jovens com oclusões normais e idades de 7 aos 11 anos; 38 casos com Classe II, 1a divisão, 10 casos com Classe II, $2^{\underline{a}}$ divisão e 9 com Classe III. Concluiu que as alterações mais significantes encontravam-se no posicionamento ântero-posterior da mandíbula, avaliado pelo ângulo SNB e na relação maxilomandibular, quando verificada pelo ângulo ANB. Nos casos de Classe II, 1a divisão, a mandíbula apresentourse mais retruída em comparação com o grupo de oclusão normal.

Um ano mais tarde, FISK et al. ${ }^{55}$ identificaram que o complexo dentofacial da Classe II variava em pelo menos seis situações: maxila e dentes superiores posicionados anteriormente em relação ao crânio; dentes superiores protruídos em suas bases ósseas; mandíbula subdesenvolvida; mandíbula com tamanho normal, mas posteriormente localizada; dentes inferiores retruídos na base óssea ou qualquer combinação dos fatores anteriormente citados. 
Os componentes dentofaciais horizontal e vertical da má oclusão de Classe II, 1a divisão, foram objeto de estudo de ALTEMUS $^{9}$ (1955). O autor avaliou telerradiografias de jovens do gênero feminino e concluiu que a maxila apresentavase anteriormente posicionada, assim como os molares superiores em relação ao grupo controle.

Estudando a morfologia facial, MARCONDES ${ }^{102}$, em 1955, comparou cefalometricamente um grupo de pacientes com Classe II, 1a divisão, com um grupo controle com oclusão normal. Verificou que a mandíbula no primeiro grupo, apresentava um menor tamanho, embora apresentasse uma similaridade com 0 grupo controle quanto aos componentes das grandezas angulares.

Em 1957, HENRY ${ }^{73}$ propôs uma classificação para a má oclusão de Classe II, $1^{\text {a }}$ divisão, dividindo-a em quatro tipos: protrusão maxilar alveolar, protrusão maxilar basal, deficiência do tamanho mandibular e retrusão mandibular.

Pesquisando as características faciais em telerradiografias de jovens com Classe II, 1a divisão e com oclusão normal, $\operatorname{KEAN}^{87}$ (1958) verificou nos casos com Classe II, que a mandíbula encontrava-se posicionada mais anteriormente em relação ao limite posterior da base craniana, porém apresentava-se com um tamanho menor do que a média, e que o trespasse horizontal acentuado resultava da posição mais para anterior dos incisivos superiores.

Com o intuito de verificar as características da Classe II e compará-las com um grupo de oclusão normal, MARTIN ${ }^{103}$, em 1958, realizou um estudo com telerradiografias de 60 jovens, sendo 20 jovens com oclusão normal e 40 com Classe II, $1^{\text {a }}$ divisão. $\mathrm{O}$ autor evidenciou que a mandíbula dos pacientes com Classe II apresentourse menor e com um posicionamento mais posterior em relação aos pacientes com oclusão normal. Os resultados revelaram também que, a espinha nasal anterior e a borda incisal do incisivo central superior localizavam-se projetadas para anterior nos casos de Classe II; da mesma forma, o ponto A posicionou-se mais anteriormente nestes casos. 
DE CASTRO ${ }^{43}$, em 1960, enfatizou que geralmente na má oclusão de Classe II, $1^{\text {a }}$ divisão a mandíbula apresenta-se retruída, necessitando de um estímulo e/ou redirecionamento de seu centro de crescimento, em vez da aplicação de forças extrabucais para retração da maxila, quando na maioria das vezes, esta se encontra bem posicionada.

Objetivando determinar as relações dentoesqueléticas de 50 jovens com Classe II, $1^{\text {a }}$ divisão, com idades variando de 8 a 15 anos, MAJ; LUZI; LUCCHESE ${ }^{99}$ (1960) verificaram que, na maioria dos casos, ocorreu uma desarmonia entre as bases apicais, com um posicionamento anterior da maxila e posterior dos côndilos mandibulares, porém o comprimento mandibular total não apresentou grandes variações. Em 78\% dos casos, observaram uma inclinação acentuada para vestibular dos incisivos superiores. Deduziram, deste modo, que a Classe II, 1 a divisão, resultou de variações dentárias e esqueléticas, com tendência para a protrusão maxilar e um aumento do trespasse horizontal, devido a posição dos dentes anteriores.

Contrariando os resultados de MAJ; LUZI; LUCCHESE ${ }^{99}$, em 1962 KING $^{89}$ ao comparar amostras de Classe I e Classe II, de adultos de ambos os gêneros, evidenciou que no grupo de Classe II, 1a divisão, a mandíbula apresentourse retrognática em relação à base do crânio, enquanto que os incisivos superiores mostraram uma maior inclinação para vestibular. Analisando a posição espacial da maxila, não encontrou diferença significante entre os dois grupos.

Investigando os tipos faciais relacionados à má oclusão de Classe II, 1a divisão, SASSOUNI ${ }^{142}$ (1970) observou 128 tipos de variações esqueléticas da maxila e mand íbula, nos sentidos horizontal e vertical.

Em 1971, ROTHSTEIN ${ }^{135}$ analisou e comparou as características morfológicas e o crescimento facial de jovens com oclusão normal e com má oclusão de Classe II, 1a divisão. Para tanto, utilizou uma amostra de 273 jovens portadores

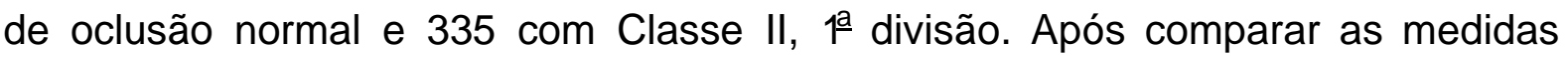


cefalométricas, concluiu que a amostra de Classe II, 1 ạ divisão apresentou uma maxila maior do que o normal, um plano palatino inclinado no sentido anti-horário e uma mandíbula bem posicionada e com tamanho e formas normais.

Estudando algumas características mandibulares quanto à posição e dimensões na Classe I e Classe II, 1a divisão, VIGORITO ${ }^{161}$, em 1973, constatou que a mandíbula apresentou uma posição mais retruída em relação à base do crânio, nos casos de Classe II, 1a divisão; a borda inferior do corpo mandibular mostrou tendência para exibir maior inclinação nos casos de Classe II e que nestes casos, o comprimento mandibular apresentou-se menor.

Com o objetivo de aprimorar a classificação das más oclusões SERVOSS ${ }^{146}$, em 1975, acrescentou quatro termos à classificação de Angle. Os termos prognatismo ou retrognatismo referem-se ao posicionamento anterior ou posterior, respectivamente, das bases ósseas em relação ao esqueleto craniofacial. Adicionalmente, os termos protrusão ou retrusão descrevem o posicionamento anterior e posterior dos dentes em relação às bases ósseas. Estas condições são distintas, porém podem apresentar-se combinadas. Concluiu que a Classe II, $1^{\underline{a}}$ divisão, pode resultar de uma protrusão dos dentes superiores, um prognatismo maxilar, uma retrusão do arco dentário inferior, um retrognatismo mandibular ou mais freqüentemente, de uma combinação destes fatores.

PFEIFFER; GROBÉTY123, em 1975, afirmaram que a má oclusão de Classe II provém da combinação de alterações dentoesqueléticas, e que na maioria dos casos, a maxila apresenta-se bem posicionada e os incisivos superiores protruídos. Entretanto, a característica mais freqüentemente observada foi a retrusão da mandíbula com os incisivos inferiores bem posicionados. Os autores alertaram ainda para a importância de um correto diagnóstico diferencial para a Classe II, indicando os mais diversos aparelhos para a sua correção.

$\mathrm{Na}$ década de 80, vários pesquisadores investigaram as características morfológicas da má oclusão de Classe II e propuseram novas classificações. 
A classificação proposta por WOODSIDE ${ }^{166}$ (1980) para definir a má oclusão de Classe II incluiu três tipos, dentoalveolar, esquelética e muscular, e foi dividida em 7 subtipos: 1) face harmoniosa com Classe II dentoesquelética; 2) protrusão do complexo nasofaríngeo e mandíbula bem posicionada; 3) complexo nasofaríngeo normal e mandíbula retruída; 4) complexo nasofaríngeo normal, mandíbula muito retruída e perfil facial bastante convexo; 5) complexo nasofaríngeo e maxila protruídos com mandíbula retruída; 6) relação maxilomandibular adequada com obstrução nasal ocasionando retrusão da mandíbula quando em repouso e 7) variação do subtipo 1 com espaço funcional livre muito aumentado.

Ainda em 1980, MOYERS et al. ${ }^{113}$ utilizaram uma combinação de programas computadorizados para descrever uma série de tipos de Classe II, com características verticais e horizontais bem definidas. Identificaram seis tipos horizontais: uma "Pseudo-classe II" ou Classe II dentária; quatro síndromes de Classe II esqueléticas graves; e um caso moderado de Classe II esquelética, com uma variedade de sintomas. Encontraram também cinco tipos verticais, o primeiro apresentava o plano mandibular acentuadamente inclinado para baixo; no segundo, os planos mandibular, oclusal e palatino encontravam-se quase paralelos entre si; o terceiro mostrava o plano palatino inclinado para cima; no quarto, os planos mandibular, oclusal e palatino apresentavam-se acentuadamente inclinados para baixo; e no quinto, os planos mandibular e oclusal denotavam normalidade, e o plano palatino encontrava-se inclinado para baixo. Por meio da marcante relação entre os dois padrões, vertical e horizontal, identificaram quinze subtipos com características bem definidas. Ressaltaram que os indivíduos de um mesmo tipo de Classe II, com uma aparência e um padrão de crescimento semelhantes, necessitavam de tratamentos similares e provavelmente deveriam responder da mesma forma.

Para obter um correto planejamento para a correção da Classe II torna-se necessário identificar a morfologia desta má oclusão. Com a finalidade de verificar a natureza e a freqüência com que ocorrem as principais características envolvidas na má oclusão de Classe II, McNAMARA JúNIOR ${ }^{107}$, em 1981, investigou 
cefalometricamente uma amostra de 277 jovens, sendo 153 do gênero masculino e 124 do feminino, com média de idade de 9 anos, incluindo tanto a Classe II, 1 a divisão como a Classe II, $2^{\underline{a}}$ divisão. Com este estudo, observou que esta má oclusão não é uma entidade clínica única, podendo resultar de inúmeras combinações de componentes dentários e esqueléticos. O autor verificou que, em média, a maxila apresentourse bem posicionada, ou até mesmo retruída enquanto que a retrusão mandibular foi a característica mais evidenciada na amostra de Classe II. Além disso, os pacientes apresentaram uma marcante variação no desenvolvimento vertical, e pelo menos na metade da amostra, observou um excessivo desenvolvimento vertical. A avaliação dentária revelou que os incisivos superiores apresentavam-se inclinados para vestibular e os inferiores bem posicionados, na maioria dos casos.

No ano seguinte, BASS $^{18}$ (1982) destacou a grande influência da musculatura bucofacial no desenvolvimento da face e no posicionamento dentário, possibilitando inclusive, alterações no crescimento das estruturas faciais. Avaliando os componentes dentoesqueléticos da má oclusão de Classe II, 1a divisão, o autor observou uma protrusão da maxila e retrusão mandibular ou ainda, em alguns casos, a maxila apresentava-se retruída e a mandíbula acentuadamente retruída.

Correlacionando a altura da base do crânio e a dimensão craniofacial na má oclusão de Classe II, 1a divisão, ANDERSON; POPOVICH ${ }^{12}$, em 1983 avaliaram jovens com idades entre 8 e 16 anos. Observaram que nesta má oclusão o ângulo da base do crânio e a altura da base craniana superior encontram-se aumentados enquanto que a altura da base craniana inferior apresenta-se diminuída. A maxila localiza-se suavemente para posterior e a mandíbula acentuadamente.

Avaliando cefalometricamente as estruturas dentoesqueléticas de 50 pacientes de ambos os gêneros, com Classe II, 1a divisão, VALE ${ }^{159}$, em 1985, concluiu que: a posição da maxila apresentou-se variável, com uma suave tendência para a protrusão; os incisivos superiores demonstraram uma tendência excessiva para a protrusão; a análise da posição mandibular, utilizando três grandezas 
cefalométricas, não permitiu uma conclusão definitiva, quando comparados entre si. Entretanto, afirmou que, uma grande porcentagem dos casos apresentou uma posição mandibular variando do normal para o retrognatismo; os incisivos inferiores apresentaram uma posição mais retrusiva; não foi observado dimorfismo genérico, e ocorreu uma acentuada predisposição para o desenvolvimento vertical excessivo do complexo craniofacial, com conseqüente aumento da altura anterior da face.

As alterações dentofaciais em jovens com más oclusões de Classe II, 1a divisão não tratados, foram pesquisadas por CARTER $^{34}$, em 1987. O autor avaliou estudos cefalométricos que compararam os valores médios para indivíduos com má oclusão de Classe II, 1a divisão com padrões cefalométricos normais. Concluiu que, nos jovens com Classe II, a maxila apresenta-se bem posicionada em relação à base do crânio e a mandíbula moderadamente retruída, e os incisivos superiores mostraram-se protruídos, quando comparados com amostras controle. $O$ autor ressaltou ainda que o aumento médio nas dimensões lineares foi quase três vezes maior nos jovens do gênero masculino, comparado ao feminino. Não obstante tenha verificado uma considerável variação individual, houve uma maior tendência de redução do trepasse horizontal nos jovens do gênero masculino, não observado no gênero feminino.

Objetivando estudar o comportamento da mandíbula na má oclusão de Classe II, $1^{a}$ divisão, BUSCHANG et al. ${ }^{32}$, em 1988, compararam o crescimento deste osso em 42 jovens do gênero feminino e 71 do masculino, dos 6 aos 15 anos de idade, com Classe II, 1 a divisão, não tratados, com um grupo de jovens possuindo oclusão normal. Os resultados demonstraram um menor crescimento da mandíbula nos pacientes com Classe II. O ângulo SN.Gn, nestes jovens apresentou um maior aumento, quando comparando com o grupo de oclusão normal, onde a mandíbula exibiu uma rotação no sentido anti-horário.

Buscando caracterizar a má oclusão de Classe II, 1a divisão PROFFIT ${ }^{126}$ (1993) afirmou que os principais componentes desta má oclusão são definidos pela 
deficiência do crescimento mandibular, por um crescimento maxilar excessivo ou ainda por uma combinação dos fatores supracitados.

Uma vez mais o objetivo de alguns estudos se concentrou no componente mandibular da má oclusão de Classe II, 1a divisão. Objetivando avaliar cefalometricamente os componentes dentoesqueléticos de jovens com más oclusões de Classe II com mandíbula bem posicionada ou retruída, SARHAN; HASHIM ${ }^{141}$, em 1994, verificaram, nos jovens com mandíbula retruída, uma retrusão maxilar œm o ângulo SNA mostrando-se diminuído, os ângulos dos planos mandibular, palatino e oclusal normalmente apresentaram-se aumentados bem como a altura facial total, e os incisivos inferiores denotaram uma inclinação correta. Por outro lado, nos jovens com mandíbulas de tamanho normal, evidenciaram uma protrusão maxilar com o ângulo SNA aumentado, os ângulos dos planos mandibular, palatino e oclusal mostraram-se diminuídos e os incisivos inferiores inclinados para vestibular.

No mesmo ano, KARLSEN ${ }^{85}$ (1994) avaliou a morfologia craniofacial na má oclusão de Classe II, $1^{\underline{a}}$ divisão, em dois grupos compostos por 24 jovens com mordida aberta e 22 com mordida profunda. Um outro grupo com 25 jovens apresentando oclusão "normal" foi mantido como grupo controle. Os resultados mostraram que os jovens com má oclusão de Classe II apresentavam um comprimento mandibular diminuído e um retrognatismo, caracterizando a principal causa da relação de distoclusão. A altura facial ântero-inferior apresentou-se maior nos jovens com mordida aberta, bem como o ângulo do plano mandibular, em comparação ao grupo controle. Nos jovens com mordida profunda, a altura facial ântero-inferior mostrou-se diminuída, em comparação com o grupo controle.

ROSENBLUM ${ }^{134}$, em 1995, se propôs a identificar os componentes esqueléticos da má oclusão de Classe II. Para o estudo, o autor utilizou telerradiografias de 103 jovens com má oclusão de Classe II e analisou 4 medidas cefalométricas para avaliação da maxila e outras 4 para a mandíbula. Os resultados demonstraram uma ampla variedade de protrusão maxilar e retrusão mandibular. De acordo com o ângulo facial de Downs, notou que $27 \%$ da amostra apresentou 
retrusão mandibular, enquanto que o ângulo NA.FH (linha NA com o plano horizontal de Frankfort) demonstrou uma protrusão maxilar em $56,3 \%$ dos jovens analisados. Assim, concluiu que o padrão predominante destes jovens foi o de protrusão maxilar com uma mandíbula normal.

Com o objetivo de comparar as características morfológicas entre a Classe I, II e III de Angle, DIBBETS ${ }^{46}$, em 1996, avaliou 170 jovens antes de receberem tratamento ortodôntico. Verificou que algumas diferenças entre a Classe I, II e III concentram-se nas dimensões da face média e base do crânio. O ângulo da base do crânio é mais fechado e as porções anterior (S-N) e posterior (S-Ba) são mais curtas na má oclusão de Classe II. O tamanho mandibular não apresentou diferença entre as más oclusões. O autor salientou que a base do crânio propicia condições para o desenvolvimento maxilar, e que a face média é a principal responsável pelas características da Classe II.

Um ano mais tarde, com o intuito de comparar longitudinalmente as alterações dentofaciais em jovens com Classe II, 1a divisão e jovens com oclusão normal, BISHARA et al. ${ }^{26}$ (1997), utilizaram dois grupos que foram estudados durante a fase de dentadura decídua à dentadura permanente. O primeiro grupo constituiurse de 30 jovens, com Classe II, $1^{\underline{a}}$ divisão, sendo 15 do gênero masculino e 15 do feminino. O grupo 2 (grupo controle) apresentava 35 jovens, com oclusões normais, sendo 20 do gênero masculino e 15 do gênero feminino. Para avaliação e comparação dos resultados, foram tomadas telerradiografias em norma lateral em três estágios diferentes, destacando-se: um primeiro estágio, dentadura decídua completa (5,5,anos); um segundo estágio, quando da total irrupção dos primeiros molares permanentes (8 anos); e por fim um terceiro estágio, dentadura permanente completa (12 anos), com exceção dos terceiros molares. Após a obtenção das grandezas cefalométricas e da análise estatística, concluíram, por meio da comparação transversal das amostras, que as diferenças no comprimento e na posição da mandíbula entre os jovens com Classe II e jovens com oclusão normal, foram significantes somente no primeiro estágio, porém não significantes no terceiro estágio. O comprimento mandibular, investigado pela grandeza linear Ar-Pog, 
encontrava-se diminuído no grupo com Classe II, em ambos os gêneros, quando da comparação com o grupo controle no primeiro estágio. Isto indica que o crescimento mandibular nos jovens com Classe II, 1a divisão, pode ocorrer num período mais tardio de desenvolvimento (segundo ou terceiro estágios), alcançando o desenvolvimento normal da mandíbula em jovens com oclusão normal. Observaram, pela comparação longitudinal dos grupos, que o padrão de crescimento esqueléticofacial praticamente não sofre alteração, com exceção da protrusão do lábio superior. A comparação da magnitude de crescimento, apontada por diferenças significantes nas grandezas cefalométricas, indicou grandes alterações na convexidade esquelética e facial dos jovens com Classe II, 1a divisão, acompanhadas por uma tendência à retrusão mandibular. O crescimento da base do crânio ocorreu similarmente em ambos os grupos, porém nos jovens com Classe II, o ângulo de convexidade esquelética diminuiu com o crescimento, enquanto que o ângulo de convexidade facial aumentou.

Na mesma linha de pesquisa do estudo anterior, BACCETTI et al. ${ }^{16}$, em 1997 utilizaram dois grupos que foram avaliados longitudinalmente (2 anos e 6 meses) desde a fase de dentadura decídua à dentadura mista. Os grupos constituíam-se de 25 jovens com má oclusão de Classe II e 22 jovens com oclusão "normal". Os autores observaram que a relação de Classe II apresentada inicialmente, se manteve ou se tornou ainda pior durante o período avaliado. $O$ padrão esquelético da Classe II caracterizourse por uma retrusão mandibular significante, por uma deficiência no comprimento efetivo da mandíbula e uma rotação deste osso no sentido horário. Por outro lado, a maxila apresentou um crescimento para anterior significante. Concluíram que os sinais clínicos da má oclusão de Classe II são evidentes na dentadura decídua e persistem na dentadura mista.

Ensejando determinar as características de jovens com Classe II, para estabelecer protocolos de tratamentos, URSI; McNAMARA JUNIOR ${ }^{158}$, em 1997, realizaram um estudo com um grupo de 29 jovens com Classe II e outro grupo (30 jovens) com oclusão normal. Comparando os grupos, verificaram uma semelhança no posicionamento da maxila e uma retrusão mandibular no grupo com Classe II. 
Quanto aos dentes, os incisivos e molares superiores apresentaram-se mais extruídos e os incisivos inferiores mais protruídos e extruídos nos jovens com Classe II.

Mais um estudo investigou as principais características da má oclusão de Classe II, $1^{\underline{a}}$ divisão, no ano de 1997. NGAN; BYCZEK; SCHEICK ${ }^{117}$ avaliaram longitudinalmente as alterações esqueléticas desta má oclusão comparando-a com as alterações em jovens com Classe I. A amostra constituiu-se de 40 jovens do gênero feminino entre as idades de 7 e 14 anos, dividida em 2 grupos de 20 jovens cada, sendo um composto por jovens com Classe I e outro por indivíduos com Classe II, $1^{\underline{a}}$ divisão. Os resultados demonstraram que não houve diferença significante entre os dois grupos na dimensão da base do crânio. A maxila apresentou-se bem posicionada em relação à base do crânio (SNA) nos jovens com Classe II. Entretanto, verificou-se uma retrusão mandibular, (SNB) e um comprimento mandibular (Ar-Gn) e do corpo mandibular (Go-Gn) diminuídos, quando da comparação entre os grupos. O ângulo do plano mandibular e o eixo "Y" de crescimento encontraram-se aumentados na Classe II, contribuindo para uma retroposição da mandíbula. A relação maxilomandibular (ANB) mostroutse significantemente maior na amostra de Classe II aos 7 anos e se manteve aumentada até a puberdade. Concluindo, os autores sugeriram que o padrão esquelético da Classe II se estabelece precocemente e se mantém até a puberdade, se não submetido à intervenção ortodôntica.

A escassez de pesquisas abrangendo grupo controle motivou HENRIQUES et al. ${ }^{72}$, em 1998, a estudarem as características dentoesqueléticas da má oclusão de Classe II, $1^{\text {a }}$ divisão, em jovens não tratados ortodonticamente. A amostra foi constituída de 25 jovens com idade inicial de 9 anos e 4 meses, que foram acompanhados longitudinalmente por 3 anos e 4 meses. Os resultados demonstraram que em $75 \%$ dos casos a mandíbula apresentou-se retruída, enquanto a maxila variou entre retruída, bem posicionada e protruída. O padrão de crescimento denotou variabilidade, com distribuição uniforme de indivíduos com predominância de crescimento vertical, horizontal e equilibrado. A altura facial 
ântero-inferior aumentou em decorrência do crescimento facial. A relação maxilomandibular não mostrou melhora significante, mantendo a discrepância esquelética da má oclusão de Classe II, $1^{a}$ divisão. Em relação ao componente dentário, verificaram que os molares e incisivos superiores acompanharam 0 crescimento maxilar, apresentando mesialização e extrusão; enquanto os inferiores também extruíram, porém com a mesialização apenas dos molares e retrusão dos incisivos agravando o trepasse horizontal.

Com o intento de estudar cefalometricamente as características da Classe II, $1^{\text {a }}$ divisão, MAIA et al. ${ }^{98}$, em 1998, utilizaram 100 jovens (50 do gênero masculino e 50 do feminino) com idades variando de 6 anos e 11 meses a 14 anos e 3 meses. A avaliação dos resultados obtidos permitiu 0 estabelecimento das seguintes conclusões: (1) predomínio de um vetor de crescimento vertical; (2) dominância do perfil facial convexo, com a maxila normal ou protruída e a mandíbula com definida tendência retrusiva e (3) os incisivos superiores e inferiores apresentaram-se inclinados para vestibular e protruídos, enquanto que 0 trepasse horizontal encontrava-se aumentado e o vertical, normal.

Também em 1998, BISHARA ${ }^{24}$ avaliou longitudinal e transversalmente as alterações mandibulares em jovens com Classe II, 1a divisão, não tratados. Para o estudo, utilizou a mesma amostra e metodologia do seu trabalho publicado em 1997. Após a análise dos resultados, concluiu que as diferenças no comprimento e na posição da mandíbula entre os jovens com Classe II e jovens com oclusão normal, foram mais significantes na dentadura decídua. A comparação da magnitude de crescimento, apontada por diferenças significantes nas grandezas cefalométricas, indicou grandes alterações na convexidade esquelética e facial dos jovens com Classe II, $1^{\text {a }}$ divisão, acompanhadas por uma tendência à maior retrusão mandibular.

As características dentofaciais e craniofaciais da má oclusão de Classe II, $1^{\text {a }}$ divisão, foram objeto de estudo de ROTHSTEIN; YOON-TARLIE ${ }^{136}$, no ano de 2000. Para a pesquisa, avaliaram 613 telerradiografias em norma lateral, sendo 278 de jovens com oclusão normal e 335 de jovens com má oclusão de Classe II, não 
tratados. Os resultados demonstraram que a mandíbula apresentou o mesmo tamanho, forma e posicionamento entre os grupos, enquanto que a maxila apresentou-se mais protruída no grupo com Classe II, assim como os incisivos e os molares superiores, que se encontraram posicionados mais mesialmente em relação ao grupo controle.

Com o objetivo de comparar as dimensões maxilomandibulares entre jovens com má oclusão de Classe II, 1a divisão, não tratados e jovens com oclusão normal, GURGEL; ALMEIDA; PINZAN ${ }^{63}$ desenvolveram, em 2000, um estudo cefalométrico. Os autores verificaram que em relação ao ponto $A$, não houve diferença significante entre os grupos, indicando que a protrusão maxilar, muitas vezes associada à má oclusão de Classe II, $1^{\text {a }}$ divisão não se manifestou neste estudo. Não obstante, os valores das medidas horizontais da mandíbula mostraram uma significante diferença e por outro lado, os valores verticais não apresentaram valores equiparáveis entre os grupos. Assim, os autores concluíram que a diferença mais evidente restringiu-se as dimensões ântero-posteriores da mandíbula, enquanto que a maxila equiparourse nos sentidos horizontal e vertical. Entretanto, o posicionamento da maxila apresentou uma variabilidade, sendo possível encontrá-la protruída ou retruída em diferentes casos.

Destacando a importância da análise facial como exame auxiliar no diagnóstico e planejamento ortodôntico, em 2001, BRANDÃO; DOMINGUEZRODRÍGUEZ; CAPELOZZA FILHO ${ }^{28}$ avaliaram as características da má oclusão de Classe II, $1^{\underline{a}}$ divisão, observadas nas telerradiografias e compararam com as características morfológicas da face, verificadas na análise facial subjetiva. A amostra constou de 30 jovens, de ambos os gêneros, com idades entre 12 e 16 anos. A análise cefalométrica mostrou perfil ósseo convexo, maxila bem posicionada e mandíbula retruída em relação à base do crânio, incisivos superiores e inferiores protruídos nas bases ósseas, trespasse horizontal acentuado e vertical moderado. 0 exame facial subjetivo mostrou um envolvimento da maxila em 3 casos (10\%); da mandíbula em 13 casos (43,3\%); associação da maxila e mandíbula em 43,3\% (13 casos) e maxila e mandíbula consideradas bem posicionadas em apenas 1 caso 
(3,3\%). Assim, concluíram que a avaliação subjetiva apresentou uma razoável coerência, comparada aos valores obtidos na análise cefalométrica.

No mesmo ano, YOU et al. ${ }^{167}$ avaliaram as alterações dentoalveolares relacionadas ao crescimento mandibular em jovens com má oclusão de Classe II. A amostra constou de 40 jovens com Classe II, não tratados, que foram comparados a uma amostra de oclusão normal de Bolton. Os autores não observaram diferenças estatísticas no crescimento mandibular entre as duas amostras. No grupo com má oclusão de Classe II o complexo dentoalveolar posicionou-se para anterior em relação à maxila (ponto $A$ ) e para posterior em relação à mandíbula (ponto $P$ ). Os resultados indicaram que 0 crescimento para anterior da mandíbula e, conseqüentemente, o posicionamento dos dentes inferiores no mesmo sentido contribuem para a correção da Classe II. Os autores afirmaram que a base biológica fundamental para o tratamento desta má oclusão consiste numa terapia que desoclui os dentes, por meio de levantamento do plano oclusal e desta forma, libera o crescimento da mandíbula.

Em 2002, KLOCKE; NANDA; KAHL-NIEKE ${ }^{91}$ estudaram longitudinalmente as características esqueléticas da má oclusão de Classe II. A amostra constou de 23 jovens com Classe II, que foram observados dos 5 aos 12 anos de idade e divididos em dois grupos de acordo com o comportamento do ângulo ANB. Um grupo de 13 jovens que apresentou uma diminuição do ângulo ANB (pelo menos 1,5 grau) durante o período de avaliação foi denominado como grupo de crescimento favorável. No outro grupo, denominado de crescimento desfavorável, os 10 jovens apresentaram um aumento dos ângulos ANB, SN.PP, do ângulo goníaco e da distância N-Me, e uma diminuição da proporção das alturas faciais posterior e anterior. Os autores afirmaram que a melhora no relacionamento maxilomandibular no grupo de crescimento favorável ocorreu devido ao posicionamento da mandíbula. No outro grupo, a rotação posterior (aumento da altura facial posterior) parece ocorrer devido a um mecanismo de compensação adaptativo pelo subdesenvolvimento da mandíbula. 
Recentemente, ALARASHI et al. $^{2}$ (2003), objetivaram avaliar as características dentoesqueléticas da Classe II, no sentido transversal. Para o estudo utilizaram radiografias póstero-anterior de 49 jovens com Classe II, não tratados, que foram comparadas com 50 jovens com Classe I, também não tratados ortodonticamente. Os resultados demonstraram uma atresia da maxila, tanto esquelética como dentoalveolar, e um estreitamento da base do nariz no grupo com Classe II. Os autores asseguraram que a constrição maxilar associou-se com um aumento vertical da maxila.

Com o objetivo de determinar alguns parâmetros cefalométricos de uma amostra brasileira portadora de má oclusão de Classe II e adicionalmente incrementar o diagnóstico ortopédico-ortodôntico, BERTOZ et al. ${ }^{23}$, em 2003, realizaram uma pesquisa. Utilizaram para o estudo 55 telerradiografias de 31 jovens do gênero feminino e 24 do masculino, com média de idade variando entre 6 e 11 anos. Os resultados revelaram que em mais da metade da amostra a maxila encontrou-se bem posicionada ou ainda retruída, e a mandíbula apresentou retrusão em relação à base do crânio. Com relação ao padrão de crescimento verificaram que $60 \%$ a $70 \%$ apresentou crescimento vertical. Os incisivos superiores encontraram-se inclinados para vestibular excessivamente e protruídos; e os inferiores, em cerca de $50 \%$ da amostra, estavam vestibularizados, sendo que na outra metade da amostra apresentavam-se bem posicionados e protruídos. Os autores afirmaram que no tratamento da Classe II deve-se considerar as características pertinentes a cada paciente.

Ainda em 2003, mais um estudo, desenvolvido por SANTOS ${ }^{139}$ contribuiu para a caracterização cefalométrica da má oclusão de Classe II, $1^{a}$ divisão, esquelética. A amostra desta pesquisa consistiu de 55 jovens brasileiros, leucodermas, de ambos os gêneros, com média de idade de 13 anos e 6 meses. Os resultados mostraram a maxila bem posicionada e a mandíbula retruída, em relação à base do crânio. Em relação à proporcionalidade das bases apicais, evidenciou-se a mandíbula com dimensão pequena e a maxila normal. O padrão facial demonstrou 
um comportamento de crescimento vertical. Os incisivos superiores e inferiores apresentaram-se inclinados para vestibular.

Sintetizando o tópico a respeito das características morfológicas da má oclusão de Classe II, $1^{\underline{a}}$ divisão observou-se uma extensa variabilidade dos componentes envolvidos em sua caracterização. Sabe-se que a má oclusão de Classe II tem um envolvimento das bases ósseas no sentido sagital, vertical e transversal, caracterizada, morfologicamente, por uma discrepância maxilomandibular, por um mau relacionamento dos arcos superior e inferior, ou por uma combinação destes fatores. Avaliando as alterações sagitais da Classe II, observa-se que esta pode estar relacionada à presença isolada ou à combinação do prognatismo maxilar, do retrognatismo mandibular, com retrusão dos dentes inferiores e protrusão dos superiores, sendo o retrognatismo mandibular considerado como um dos maiores responsáveis por esta má oclusão. Pode também existir uma combinação destes fatores com um excesso vertical da maxila ou uma deficiência transversal desta base óssea, denotando a presença de alterações nos três planos: horizontal, vertical e transversal. Mesmo com uma maior tendência a um retrognatismo mandibular, a maioria das pesquisas ressalta a grande variação de apresentações dentárias e esqueléticas. Assim, é imprescindível o conhecimento acerca do crescimento craniofacial e da morfologia da má oclusão no intento de diagnosticar e instituir um tratamento adequado. 


\subsection{TRATAMENTO DA MÁ OCLUSÃO DE CLASSE II, $1^{a}$ DIVISÃO COM O APARELHO EXTRABUCAL CONJUGADO (SPLINT MAXILAR)}

Observa-se na literatura uma miríade de estudos concernentes ao aparelho extrabucal com tração cervical e/ou occipital. No entanto, poucos são as pesquisas referentes à utilização do aparelho extrabucal conjugado ("splint" maxilar). Neste tópico serão revisados apenas os artigos sobre o aparelho extrabucal modificado, contudo, um breve histórico faz jus à tão importante aparelho.

\section{Histórico}

No inicio do século XIX, surgiu pela primeira vez o uso da força extrabucal, quando CELLIER ${ }^{35}$ desenvolveu um dispositivo de ancoragem extrabucal para prevenir a luxação da mandíbula, durante as extrações dentárias.

O pioneiro a utilizar forças extrabucais com finalidade ortodôntica foi KINGSLEY ${ }^{90}$, que em 1875, popularizou a utilização da ancoragem occipital, seguido logo depois por $\operatorname{FARRAR}^{52}$ (1886), que a utilizou para retração dos dentes ântero-superiores.

Em 1893, BAKER ${ }^{17}$ introduziu o uso de elásticos intermaxilares, nos quais o arco superior era ligado ao arco inferior. Surgiu então a chamada ancoragem intermaxilar, que se tornou muito popular nesta época.

Entretanto, com a grande aceitação da filosofia não extracionista de Angle, somada ao advento da ancoragem intermaxilar de Baker, os aparelhos extrabucais perderam sua popularidade, durante aproximadamente quatro décadas. 
Após este longo período o aparelho extrabucal foi novamente reconhecido por OPPENHEIM ${ }^{120}$, na década de 30 (na Europa) e por BRODIE ${ }^{29}$ (EUA) como meio eficaz de ancoragem, evidenciando seus efeitos ortodônticos e ortopédicos.

Com os resultados dos estudos de TWEED ${ }^{155}$ (1966), indicando freqüentemente extrações dentárias para a correção das más oclusões, o emprego das forças extrabucais definitivamente voltou a ter popularidade.

\section{Revisão dos estudos em ordem cronológica}

McCALIN ${ }^{106}$, em 1953, foi o pioneiro em utilizar um aparelho extrabucal inserido em tubos soldados aos grampos de aparelhos removíveis. No entanto, em 1961, PLINT ${ }^{124}$ verificou que ocorriam distorções dos grampos destes aparelhos em função da força excessiva e propôs a bandagem dos molares onde o arco facial seria inserido e o aparelho removível apresentaria grampos em forma de "C" nos molares, abraçando a banda por cima, evitando assim tais problemas.

Em 1965, COUSINS; CLARK ${ }^{39}$ descreveram outro aparelho cujos tubos eram incorporados no acrílico do aparelho removível, na distal dos incisivos centrais superiores e com levantamento de mordida.

THUROW $^{148}$ expressou, em 1975, sua preocupação com os efeitos secundários indesejáveis e a sobrecarga que os molares sofriam em virtude das forças extrabucais intensas e identificou alguns desses problemas: (1) o componente vertical das forças produzem inclinações colaterais vestibulolinguais dos dentes de ancoragem; (2) o nível de aplicação da força é limitada pela tolerância e a resposta dos tecidos de suporte destes dentes e (3) a movimentação dos molares é a alteração dentária predominante. Observando essas considerações, desenvolveu um aparelho destinado à correção das más 
oclusões de Classe II, 1a divisão, cujo diagnóstico apontava para uma protrusão maxilar ou dentoalveolar. O aparelho consistia de uma placa de acrílico que recobre o palato, as superfícies oclusais dos dentes posteriores, estendendo-se até $2 / 3$ das superfícies vestibulares desses dentes e as superfícies palatinas, incisais e vestibulares dos incisivos superiores. O braço interno do arco extrabucal é incorporado no acrílico e percorre as superfícies oclusais dos dentes posteriores. Observando os efeitos de seu novo aparelho, verificou que a desoclusão promovida pelo recobrimento oclusal, facilitou tanto a movimentação dentária como a correção de deslocamentos funcionais da mandíbula, porque eliminou as interferências existentes. Esse recobrimento possibilitou ainda uma distribuição uniforme da força por todo o arco dentário, promovendo um controle vertical eficiente. Como resultado, obteve uma distalização dos dentes posteriores, um controle de inclinação dos dentes anteriores conforme são deslocados para lingual e, a inclinação distal dos caninos. Evidenciou também uma restrição do deslocamento ântero-inferior do complexo maxilar, com conseqüente restrição da rotação mandibular no sentido horário, que advém do crescimento vertical desproporcional da maxila.

Com o propósito de realizar pequenos ajustes na inclinação dos incisivos superiores, que freqüentemente apresentam-se vestibularizados nas más oclusões de Classe II, $1^{\text {a }}$ divisão, JOFFE; JACOBSON ${ }^{82}$, em 1979, desenvolveram um aparelho similar ao de $\mathrm{THUROW}^{148}$. Os autores incorporaram um arco vestibular à placa de acrílico e verificaram como efeito do aparelho uma retração em massa do arco dentário superior, com algum grau de restrição de crescimento maxilar. Observaram também uma melhora no trespasse horizontal e da relação molar.

BASS $^{18}$, em 1982, desenvolveu um outro tipo de "splint"maxilar, que consistia em uma placa de acrílico cobrindo o palato e preso aos dentes posteriores por meio de grampos. Lateralmente à área dos primeiros molares, foram posicionados tubos que permitiram a colocação do arco extrabucal. Um parafuso expansor para 
ajustes laterais, conforme o arco superior é deslocado posteriormente, foi introduzido. A tração foi direcionada para o centro de resistência maxilar e, como os dentes transmitem a força extrabucal para os ossos, e desses para as suturas que os articulam ao esqueleto facial, argumentou que foi a compressão dessas suturas que levou à restrição do crescimento nesse nível, inibindo o deslocamento para frente da maxila. Enquanto o crescimento maxilar é inibido, uma redução da discrepância da base dentária deve ocorrer. As forças agindo em uma direção vertical para cima na dentadura superior, pela ação do encapsulamento dos dentes posteriores, tenderam a retardar a erupção destes e esse efeito é vantajoso na correção da relação molar de Classe II, uma vez que os molares inferiores estão livres para irromper para frente e para cima. Essa correção posteriormente foi auxiliada por uma conseqüente redução na tendência da mandíbula rotar no sentido horário durante o tratamento, um efeito adverso, freqüentemente visto com a terapia extrabucal convencional. O movimento distal em massa, de todo o arco dentário superior constituiu em outro efeito benéfico observado. Os resultados cefalométricos mostraram a manutenção do valor do ângulo SNA e o aumento do SNB, gerando uma redução do ângulo ANB de 2,50, em média.

Interessado em associar a força extrabucal ao aparelho removível, FERGUSON ${ }^{53}$, em 1983, propôs a inserção do arco extrabucal na altura dos molares, soldando um tubo em um fio de $0,9 \mathrm{~mm}$ sobre os grampos de Adams. Afirmou que desta forma não há perigo de distorção dos grampos, além da vantagem de não ser necessário bandar os molares e da praticidade do arco facial poder ser retirado, mantendo-se o aparelho removível na boca.

Com o objetivo de avaliar cefalometricamente as alterações promovidas pelo "splint" maxilar, CALDWELL; HYMAS; TIMM ${ }^{33}$, em 1984, realizaram uma pesquisa. A amostra constou de dois grupos com Classe II, sendo um grupo de 47 jovens tratados com o aparelho extrabucal associado ao removível e outro grupo de 52 jovens com a mesma má oclusão que não receberam tratamento 
ortodôntico. Os resultados mostraram uma restrição do crescimento maxilar para frente e para baixo, com diminuição do ângulo SNA e uma melhora significativa na relação maxilomandibular. Não houve alterações significantes no padrão de crescimento, porém observourse um aumento da altura facial ântero-inferior. Com relação às alterações dentárias, constataram uma redução do trespasse vertical e horizontal, lingualização dos incisivos superiores e distalização dos molares superiores, enquanto os inferiores verticalizaram, mesializaram e extruíram.

Outro estudo, realizado por FOTIS et al. ${ }^{56}$, em 1989, objetivou avaliar os efeitos do "splint" maxilar. O aparelho utilizado diferia do "splint" original, pois os tubos para o arco extrabucal eram inseridos diretamente no acrílico, na região dos molares. Verificaram que, em todos os casos, houve uma redução no trespasse horizontal. O crescimento da maxila apresentou uma restrição no sentido sagital (SNA) e vertical e a mandíbula protruiu (SNB). Os incisivos superiores e inferiores inclinaram para lingual, os molares superiores distalizaram e os inferiores extruíram e mesializaram.

No ano seguinte (1990), SEÇKIN; SURUCU ${ }^{145}$ avaliaram os efeitos produzidos por um "splint" maxilar semelhante ao de THUROW ${ }^{148}$, porém com o acrílico recobrindo apenas as superfícies oclusais, vestibulares e linguais, deixando a mucosa palatina livre. A amostra constitui-se de 15 pacientes com má oclusão de Classe II, 1a divisão com protrusão maxilar. Os resultados mostraram uma restrição do crescimento maxilar com diminuição do ângulo SNA e mínima alteração no posicionamento da mandíbula. No sentido vertical observaram um suave aumento dos ângulos SN.PP, SN.GoGn e FMA. Os incisivos superiores retruíram e inclinaram para lingual e o trepasse horizontal apresentou melhora significante.

A incorporação de uma mola do tipo Coffin nos aparelhos que associam placas removíveis à tração extrabucal, foi recomendado por ROCK ${ }^{133}$, em 1990, 
para prevenir o cruzamento da mordida na região posterior, à medida que os molares superiores são distalizados.

O "splint" maxilar de THUROW ${ }^{148}$ sofreu algumas modificações no ano de 1991, quando HENRIQUES et. al. ${ }^{69}$ incorporaram ao aparelho um parafuso expansor para ajustes laterais e um arco vestibular para pequenos movimentos de inclinação dos incisivos superiores. Além disso, grampos de Adams foram utilizados para melhorar a retenção, e o arco extrabucal foi inserido na região dos pré-molares. Convencionaram chamar este aparelho de AEB conjugado e com ele obtiveram um efeito de restrição do deslocamento anterior da maxila, traduzido por uma diminuição do ângulo SNA e manutenção do seu comprimento efetivo. Houve um avanço da mandíbula anteriormente, mostrando um aumento do ângulo SNB e do seu comprimento efetivo. Os incisivos superiores inclinaram para lingual, enquanto os incisivos inferiores vestibularizaram moderadamente. $O$ controle vertical pôde ser demonstrado pelas alterações insignificantes no padrão de crescimento e no pequeno aumento observado da altura facial ântero-inferior.

Enfatizando o tratamento ortopédico dos problemas esqueléticos, durante a fase de crescimento, HENRIQUES; FREITAS; SANTOS PINTO ${ }^{68}$, em 1991, apresentaram um caso clínico de correção de uma má oclusão de Classe II, 1 a divisão utilizando o AEB conjugado. A paciente com 8 anos de idade exibia cefalometricamente, um perfil ósseo convexo, crescimento vertical, incisivos superiores e inferiores vestibularizados e um ângulo nasolabial normal. A relação maxilomandibular apresentava-se deficiente, mas a mandíbula encontrava-se bem posicionada, os comprimentos efetivos da maxila e da mandíbula normais, porém a altura facial ântero-inferior estava aumentada. Os valores cefalométricos obtidos após o tratamento revelaram que a má oclusão foi corrigida em decorrência da redução da velocidade de crescimento maxilar, enquanto as demais estruturas do complexo craniofacial mantiveram seu curso normal de desenvolvimento. A maxila teve seu comprimento efetivo aumentado (Co-A) durante todo o período do tratamento, porém o comprimento mandibular efetivo 
aumentou ainda mais (Co-Gn), resultando com isso uma redução significativa do ângulo ANB. No sentido vertical, um ligeiro aumento do ângulo do plano palatino e da altura facial ântero-inferior foi constatado, porém o ângulo do plano mandibular com a base do crânio diminuiu, exibindo tendência de rotação no sentido antihorário.

HENRIQUES ${ }^{67}$, em 1993, comparou o AEB conjugado com outros dois tipos de aparelhos de tração extrabucal. A amostra constou de 75 jovens divididos em três grupos de 25 cada: grupo I tratado com ancoragem extrabucal cervical, grupo II tratado com AEB conjugado e grupo III tratado com ativador associado à ancoragem extrabucal. Os resultados demonstraram restrição significante do crescimento da maxila nos três grupos, crescimento discreto da mandíbula nos grupos I e II e crescimento significante no grupo III, o que levou à diminuição do ângulo ANB, melhorando a relação maxilomandibular. Concluiu que o padrão de crescimento não foi alterado, baseado no comportamento da medida SN.GoMe, apresentando apenas um pequeno aumento da inclinação do plano palatino e da altura facial ântero-inferior. Os incisivos superiores inclinaram para lingual e os inferiores não foram influenciados pelo tratamento. Os molares superiores distalizaram nos três grupos.

Com o objetivo de estudar cefalometricamente os efeitos de um "splint" maxilar modificado combinado com uma tração extrabucal anterior alta, ÜNER; EROGLU ${ }^{156}$, em 1996, avaliaram 13 pacientes tratados com este aparelho. Observaram uma melhora significante dos trespasses horizontal e vertical. A protrusão maxilar diminuiu, enquanto que a mandíbula protruiu. Os molares superiores distalizaram, os inferiores mesializaram e os incisivos superiores inclinaram para vestibular. Verticalmente, a altura dentoalveolar da maxila diminuiu significantemente e o ângulo do plano mandibular não se alterou.

Objetivando descrever, comparativamente, os resultados de duas modalidades de interceptação da má oclusão de Classe II, $1^{\text {a }}$ divisão, 
MARTINS ${ }^{105}$, em 1997, desenvolveu uma pesquisa. A amostra constou de 58 jovens, sendo 23 tratados com o aparelho extrabucal removível, 18 tratados com o bionator de Balters e 17 jovens apresentando a mesma má oclusão foram mantidos como controle. Os resultados mostraram que as duas modalidades de tratamento exibiram alterações dentoalveolares e esqueléticas diferentes. $O$ autor relatou que no grupo tratado com o aparelho extrabucal removível houve uma restrição do crescimento anterior da maxila, com diminuição do ângulo SNA, apesar de seu comprimento efetivo ter demonstrado um ligeiro aumento; crescimento mandibular verificado tanto pelo aumento do ângulo SNB, como pelo comprimento efetivo demonstrado pela medida Co-Gn. O ângulo ANB diminuiu, resultado do crescimento diferencial entre maxila e mandíbula; o padrão de crescimento mostrou-se inalterado, enquanto a altura facial ântero-inferior aumentou. Houve extrusão e inclinação para lingual dos incisivos superiores, distalização dos molares superiores, aumentando a inclinação distal. Já os incisivos inferiores extruíram, protruíram e acentuaram a inclinação para vestibular, e os molares inferiores mesializaram e extruíram. Concluiu que as respostas mais significativas nos grupos tratados foram alterações dentoalveolares. Enquanto o aparelho extrabucal removível promoveu a correção ântero-posterior por alterações dentoalveolares na maxila, o Bionator promoveu $68 \%$ de alterações dentoalveolares e $32 \%$ de alterações esqueléticas, com um mecanismo de ação predominantemente na face inferior.

Com o objetivo de comparar as alterações dentoesqueléticas da má oclusão de Classe II, 1a divisão sem tratamento com as tratadas por dois tipos de aparelhos ortodônticos, MALTAGLIATI ${ }^{100}$, em 1997, avaliou 75 pacientes. A amostra constou de 150 telerradiografias em norma lateral, sendo uma inicial e outra final de um grupo controle (grupo 1) e de dois experimentais. Os pacientes dos grupos experimentais foram tratados com o AEB conjugado (grupo 2) e com aparelho fixo associado ao AEB cervical (grupo 3). A análise dos resultados revelou que há pouca alteração no padrão de crescimento e que a altura facial ântero-inferior aumentou em todos os grupos. Não houve melhora significante da relação maxilomandibular no grupo controle, enquanto que, nos grupos tratados, 
a maxila foi retruída e, conseqüentemente, 0 ângulo ANB diminuiu significantemente. As alterações dentoalveolares demonstraram que o aparelho utilizado no grupo 2 (AEB conjugado) foi eficiente no controle vertical do crescimento maxilar e na extrusão dos dentes superiores posteriores e anteriores. Estes, em ambos os grupos tratados, foram movimentados para distal e lingual, respectivamente, conduzindo à uma relação molar normal e à redução do trespasse horizontal aumentado. No grupo controle, no entanto, os dentes superiores e inferiores desenvolveram-se em uma direção ântero-inferior, mantendo as características da má oclusão de Classe II, 1a divisão.

A utilização de aparelhos extrabucais constitui uma alternativa para o tratamento das más oclusões de Classe II, principalmente nos casos com protrusão maxilar e/ou dentoalveolar. Observa-se na literatura diversos trabalhos apresentando os efeitos do aparelho extrabucal removível em casos clínicos individuais, principalmente no período do final da década de 90 e início deste século.

Um caso clínico de paciente que apresentava Classe II, 1a divisão e sobremordida profunda tratado com um aparelho removível conjugado à ancoragem extrabucal, modificado no ponto de aplicação da força extrabucal, transportando-no para uma região mais anterior, entre os incisivos laterais e caninos superiores, foi relatado por HENRIQUES et al. ${ }^{70}$, em 1997. Com a mudança, a linha de ação da força passava à frente do centro de resistência da maxila, gerando um componente de intrusão da porção anterior do arco dentário. A diminuição dos valores do comprimento efetivo da maxila e do ângulo SNA, denotou uma estrição do crescimento anterior da maxila. Apesar do discreto crescimento mandibular, o ângulo ANB diminuiu, melhorando o relacionamento maxilomandibular. A sobremordida profunda foi atenuada em $1 \mathrm{~mm}$ e os incisivos superiores intruíram e vestibularizaram. O plano palatino apresentou um ligeiro aumento do ângulo com a base do crânio, interpretado como uma manifestação do padrão de crescimento do paciente. 
Com o intuito de investigar as alterações dentárias e esqueléticas de jovens com má oclusão de Classe ॥, KEELING et al. ${ }^{88}$, em 1998, utilizaram os aparelhos Bionator e extrabucal com plano de mordida para o tratamento precoce da Classe II. Estudaram 3 grupos, sendo um controle composto de 81 jovens que não receberam tratamento, outro com 78 jovens tratados com o Bionator e ainda um grupo com 90 jovens tratados com o aparelho extrabucal. Utilizaram telerradiografias em norma lateral para a comparação entre os grupos, obtidas ao início, após a correção da relação molar de Classe II, e 2 anos pós-tratamento. Verificaram, nos dois grupos tratados, uma correção da relação molar de Classe II, uma redução do trespasse horizontal e da discrepância maxilomandibular, bem como uma inclinação posterior dos dentes póstero-superiores. No entanto, ambos os aparelhos utilizados não afetaram o crescimento maxilar, mas propiciaram um aumento no crescimento anterior da mandíbula. As alterações esqueléticas mostraram-se estáveis um ano após o término do tratamento, enquanto que as alterações dentárias apresentaram recidiva.

Em 2001, SANTOS PINTO et al. ${ }^{140}$ apresentaram um caso clínico com má oclusão de Classe II, 1a divisão tratado com o AEB conjugado. Inicialmente, o paciente apresentava a maxila protruída e a mandíbula bem posicionada em relação à base do crânio, um aumento da altura facial ântero-inferior e tendência de crescimento vertical. Quanto ao padrão dentário, os incisivos apresentavam-se bem posicionados e os inferiores protruídos na base óssea. Na análise facial, verificaram uma convexidade do perfil mole. Os resultados do tratamento sobre as estruturas dentárias e esqueléticas evidenciaram a correção da má oclusão por meio da restrição do crescimento maxilar no sentido ântero-posterior e vertical, crescimento mandibular mais para frente que para baixo (rotação anti-horária) e controle de erupção dos molares e dos incisivos.

Por meio de um caso clínico, ALMEIDA et al. ${ }^{6}$, em 2002, descreveram o uso do aparelho extrabucal conjugado no tratamento da má oclusão de Classe II, 1a divisão destacando seus efeitos sobre o complexo dento-esquelético-facial. As 
medidas cefalométricas iniciais da paciente mostravam uma maxila protruída, suave deficiência mandibular e uma discrepância maxilomandibular acentuada. Os incisivos superiores e inferiores encontravam-se vestibularizados e protruídos. Após o tratamento, evidenciaram uma restrição do crescimento anterior da maxila, bem como a liberação do crescimento mandibular, proporcionando a correção na relação sagital das bases ósseas. Os incisivos superiores e inferiores foram inclinados para lingual e o ângulo nasolabial aumentou, melhorando sensivelmente o posicionamento do lábio superior.

Preocupados com a correção precoce da má oclusão de Classe II, 1a divisão ALMEIDA et al. $^{8}$, em 2002, apresentaram outro caso clínico mostrando a efetividade da terapêutica ortodôntica em duas fases. Na primeira etapa, o paciente que estava na fase de dentadura mista tardia (segundo período transitório) utilizou o AEB conjugado para correção da discrepância na relação maxilomandibular. Numa segunda etapa, instituiu-se o aparelho ortodôntico fixo para corrigir ou melhorar o posicionamento dos dentes. Os autores afirmaram que a intervenção precoce com aparelho ortopédico mecânico objetiva a correção dos problemas esqueléticos e dentários, modificando 0 relacionamento maxilomandibular, bem como movimentando os dentes para suas posições ideais nas bases ósseas, buscando um bom perfil facial.

Em 2002, WHEELER et al. ${ }^{164}$ avaliaram a efetividade do tratamento precoce da má oclusão de Classe II, $1^{\text {a }}$ divisão com os aparelhos bionator e AEB com plano de mordida e compararam com um grupo não tratado. Em relação aos objetivos alcançados com o tratamento, verificou-se um índice de $83 \%$ para 0 grupo tratado com o Bionator, $100 \%$ para o grupo do AEB com plano de mordida e $14 \%$ para o grupo controle. Os autores relataram que ambos os aparelhos produzem alterações dentoesqueléticas que corrigem a má oclusão de Classe II, 1ㅡㅡ divisão, sendo que as alterações esqueléticas são estáveis e as dentárias tendem a recidivar. Concluíram que o tratamento precoce com o AEB com plano de mordida parece ser mais efetivo que a terapêutica com o Bionator. 
No mesmo ano (2002), JACOBS; SAWAENGKIT ${ }^{76}$ também avaliaram a eficácia de dois aparelhos ortopédicos, Bionator e o AEB com plano de mordida, no tratamento da má oclusão de Classe II, 1a divisão. O estudo incluiu a avaliação dos pesquisadores da Universidade da Flórida (UFLORIDA) e da Carolina do Norte (UNC). Os grupos tratados foram comparados a um grupo controle não tratado. Os resultados demonstraram que $13 \%$ dos casos não tratados, $38 \%$ dos casos tratados com Bionator e 50\% do grupo de AEB com plano de mordida apresentaram correção da relação molar. Os grupos experimentais mostraram redução equivalente do ANB. Apenas $32 \%$ dos casos não tratados apresentaram melhora na relação maxilomandibular, enquanto que nos grupos tratados o índice foi de $80 \%$. Os autores observaram que o Bionator corrigiu satisfatoriamente $30 \%$ dos casos e 0 AEB com plano de mordida $40 \%$ da amostra. 


\subsection{TRATAMENTO DA CLASSE II, 1a DIVISÃO COM O BIONATOR}

Os aparelhos ortopédicos para o tratamento da má oclusão de Classe II, 1a divisão têm sido utilizados desde o século XIX. Inúmeros tipos de dispositivos foram desenvolvidos para a correção desta má oclusão. Neste tópico serão revisados os estudos científicos concernentes ao tratamento da Classe II, com o Bionator e/ou Ativador.

\section{Considerações sobre o Bionator}

O Bionator é um aparelho funcional derivado do ativador de Andresen que foi introduzido na década de cinqüenta por Wilhelm Balters $\left(E I R E W^{49}\right)$. Para compreender adequadamente as características e o mecanismo de ação do Bionator, torna-se de fundamental importância o conhecimento da filosofia de seu criador, visto que o aparelho é o produto desta filosofia. Assim, Balters considerou que as más oclusões originavam-se da falta de equilíbrio da função muscular, postura anormal e da relação espacial da face fora dos padrões de normalidade. $O$ sistema de tratamento com o aparelho incluía a associação de exercícios posturais, ginástica e dieta alimentar. Os seguidores desta filosofia de tratamento foram orientados a instalar anteparos para a língua e aparelhos de exercícios em suas clínicas, para supervisão e guia de treinamento postural nos pacientes. Os objetivos do tratamento com o Bionator eram, segundo EIREW ${ }^{49}$ : (1) permitir o selamento labial e promover o contato do dorso lingual com o palato mole; (2) eliminar o trauma na mucosa, provocado pela mordida profunda; (3) corrigir a retrusão mandibular e a má posição da língua; (4) corrigir a curva de Spee, se necessário, pela ação do aparelho que impede a interposição da língua e mucosa jugal entre os arcos dentários.

De acordo com a filosofia de Balters (ASCHER ${ }^{15}$, 1977), os pontos essenciais para um tratamento adequado, são: (1) permitir o selamento labial e promover o contato do dorso lingual com o palato mole; (2) aumentar o espaço bucal e treinar a função muscular; (3) propiciar uma mordida topo-a-topo dos incisivos; (4) promover 
um aumento mandibular, que por sua vez, aumenta o espaço bucal, tornando possível uma melhor posição da língua; (5) conseguir um melhor relacionamento dos maxilares, da língua e da dentição, como também dos tecidos moles circunjacentes.

Na tentativa de alcançar estes objetivos, Balters desenvolveu o Bionator, que posteriormente foi modificado por Ascher, tornando-o menor em tamanho que 0 Ativador original de Andresen, possibilitando seu uso contínuo (diurno e noturno) e mais adequado principalmente durante a fala. Não obstante o aparelho se tornou menor e mais leve, continuou estável e eficaz, podendo ser movimentado livremente pelo paciente dentro da cavidade buca ${ }^{83}$.

\section{Revisão dos estudos em ordem cronológica}

Um dos primeiros estudos cefalométricos sobre a ação do Bionator foi publicado em 1966 por $\mathrm{MEACH}^{109}$. O autor avaliou e comparou as alterações do perfil esquelético em três grupos de jovens; dois que receberam o tratamento da Classe II, $1^{\underline{a}}$ divisão por meio de forças extrabucais e aparelhos funcionais e um utilizado como controle. O grupo tratado com o ativador, semelhante ao Bionator, constituiurse de 30 jovens, de ambos os gêneros, com idade inicial média de 10 anos e 3 meses, enquanto que o grupo tratado com o aparelho extrabucal foi composto por 46 jovens, de ambos os gêneros, e média de idade de 9 anos e 4 meses. Utilizou um grupo controle, composto por 34 jovens de ambos os gêneros e média de idade de 9 anos e 6 meses. Observou que o aparelho funcional influenciou favoravelmente a posição do pogônio para anterior, promovendo uma diminuição do ângulo FMA e aumento do ângulo facial. Deste modo, o autor verificou uma melhora no perfil esquelético, devido à normalização do processo de crescimento da Classe II, por meio da alteração dos componentes verticais e horizontais do complexo dentofacial, principalmente na região do côndilo mandibular.

Um ano após, FREUNTHALLER ${ }^{60}$ propôs verificar as alterações advindas da utilização do ativador em jovens com Classe II, 1a divisão com retrusão mandibular. A amostra constou de 35 jovens de ambos os gêneros, sendo 18 do gênero feminino 
e 17 do masculino, com idades variando entre 9 e 15 anos. Verificou que as maiores alterações ocorreram pela combinação de fatores dentoalveolares, do crescimento e deslocamento anterior da mandíbula.

POSEN ${ }^{125}$, em 1968, considerou o monobloco como um adjunto útil no tratamento da Classe II, 1a divisão. Indicou este aparelho para pacientes em crescimento, podendo ser utilizado preferencialmente a outros métodos, desde que, os arcos superior e inferior apresentem-se alinhados e sem diastemas, e uma postura normal do lábio superior. Nos casos de má oclusão severa de Classe II tratados com outros tipos de aparelhos, indicou também o monobloco como aparelho de contenção, durante o período noturno. Afirmou que o monobloco pode ser utilizado associado aos aparelhos fixos na Classe II, uma vez que proporciona a correção do relacionamento maxilomandibular.

Ao estudarem a resposta morfogenética ao tratamento com o ativador, HARVOLD; VARGERVIK ${ }^{64}$, em 1971, observaram que os músculos retratores da mandíbula, transmitem suas forças à maxila, mantendo ortopedicamente a sua posição. Assim, constataram uma redução do crescimento anterior da maxila, por meio do ângulo SNA. Por outro lado, concluíram que não houve aumento significante no comprimento mandibular. Verificaram um aumento significante na altura do processo alveolar na região dos molares.

Com o intuito de descrever o alcance e as limitações do tratamento com 0 ativador, TULLEY ${ }^{151}$, em 1972, observou que as alterações mais significantes produzidas pelo aparelho localizavam-se na região dentoalveolar. Notificou que ocorre uma contração e estiramento dos músculos da mastigação, proporcionando uma tração no arco superior, causando um efeito semelhante ao que ocorre com a utilização da ancoragem extrabucal, porém com menor intensidade. O autor contraindica o ativador nos casos de Classe II com mordida aberta anterior não relacionada com hábitos de sucção ou posicionamento lingual atípico. 
O ativador destina-se principalmente, segundo JORGENSEN ${ }^{83}$ (1974), para casos de má oclusão de Classe II que não necessitam de extrações e com retrusão mandibular. Sugeriu como vantagem do tratamento, a possibilidade de iniciá-lo por volta dos 9 anos de idade, durante a fase de dentadura mista. Advogou a grande efetividade nas más oclusões influenciadas pela sucção digital, interposição labial, respiração bucal e outros hábitos. Recomendou ainda a instituição precoce deste aparelho numa fase preliminar e posteriormente como contenção. Concluiu que os ativadores não apresentam efetividade nas más oclusões que envolvem rotações, inclinações excessivas e más posições dentárias individuais.

Estudando os efeitos do tratamento com o ativador nas más oclusões de Classe II, na fase de dentadura mista, WIESLANDER; LAGERSTRÖM ${ }^{165}$, em 1979, compararam um grupo de pacientes tratados e outro com a mesma má oclusão, porém não tratados. Os critérios para seleção e equiparação dos pacientes dos dois grupos basearam-se na idade, gênero, má oclusão e tempo de observação. O grupo experimental e o grupo controle apresentaram 30 pacientes cada, de ambos os gêneros. Obtiveram telerradiografias em norma lateral, no início e final do tratamento e após um ano de contenção. Verificaram, após a análise e comparação cefalométrica entre os grupos, que a região dentoalveolar sofreu maior efeito durante o tratamento, principalmente na posição dos incisivos superiores, que inclinaram-se para lingual e os inferiores que apresentaram suave intrusão, sem experimentar protrusão significante. Os efeitos ortopédicos na maxila foram limitados, apesar de alguns casos apresentarem respostas bastante satisfatórias. Observaram uma melhora significante na relação ântero-posterior maxilomandibular, com um aumento na altura facial inferior e pequeno incremento no plano mandibular.

Com a finalidade de averiguar e comparar os efeitos dentoesqueléticos do Bionator, quando utilizado nas fases pré-pubertária e pubertária, JANSON ${ }^{78,79}$ publicou, em 1977 e 1978, uma seqüência de dois estudos cefalométricos. A amostra constou de 207 jovens com Classe II, sendo 134 tratados e 73 não tratados, que serviram como grupo controle. Obteve telerradiografias ao início e ao final do tratamento, que durou de 12 a 18 meses, após a obtenção de uma relação molar de 
Classe I e um trespasse vertical de $2 \mathrm{~mm}$. Utilizou radiografias carpais para analisar em qual fase (pré-pubertária e pubertária) o paciente se encontrava. Os resultados demonstraram que as alterações dentoalveolares foram mais pronunciadas durante o estágio pré-pubertário, enquanto que as alterações esqueléticas foram durante o estágio pubertário. Os efeitos dentoalveolares incluíram protrusão dos incisivos inferiores e retrusão dos superiores. Por outro lado, verificou efeitos esqueléticos significantes durante o estágio pubertário, ocorrendo um aumento no comprimento mandibular.

PFEIFFER ${ }^{122}$, em 1980, correlacionou o crescimento craniofacial com o ativador no tratamento da Classe II. Afirmou que o crescimento pode favorecer ou limitar o tratamento nos pacientes jovens, e que este nem sempre pode ser utilizado de maneira favorável ou na época adequada, em função de outros fatores. Considerou inapropriado postergar o início do tratamento ortodôntico até a época do surto máximo de crescimento craniofacial, devido: a um decréscimo rápido da adaptação dos tecidos tegumentares neste período; à possibilidade do paciente apresentar problemas psicológicos, resultando na diminuição da cooperação do mesmo; maior possibilidade de extrações; à erupção dos segundos molares, dificultando a distalização dos primeiros molares; e ao comprometimento da estabilidade a longo prazo, em razão da menor adaptabilidade da musculatura bucofacial. Assim, concluiu que o tratamento com aparelhos ortopédicos, os quais os efeitos excedem o crescimento normal, deve ser iniciado em jovens do gênero feminino acerca dos 10 anos de idade e finalizá-lo próximo aos 13 anos e, nos pacientes do gênero masculino, aos 11 anos e 6 meses, terminando aos 14 anos. Desta forma, inicia-se o tratamento ortopédico antes do surto de crescimento, finalizando-o um ano após o mesmo.

Apresentando detalhes de construção, bem como de manipulação clínica do Bionator, EIREW ${ }^{4}$, em 1981, enfatizou os 4 principais objetivos desta terapia: (1) eliminação da pressão do lábio e da relação anormal entre lábios e incisivos; (2) eliminação de trauma à mucosa palatina em decorrência de sobremordida profunda; (3) correção da retrusão mandibular e da má posição da língua e (4) correção da 
curva de Spee, se necessário, pela ação do aparelho que impede a interposição da língua e mucosa jugal entre os arcos dentários.

Em 1982, SCHULHOF; ENGEL ${ }^{144}$ propuseram reavaliar cefalometricamente os resultados obtidos com os aparelhos funcionais e com o tratamento fixo Edgewise no tratamento da Classe II, $1^{1}$ a divisão. Examinaram 4 tipos de aparelhos funcionais: Bionator, Bimler, Ativador e Fränkel. O grupo tratado com a técnica Edgewise constou de 33 jovens, sendo 15 do gênero masculino e 18 do gênero feminino, com média de idade de 12 anos e 9 meses. Os resultados mostraram que o Bionator proporcionou um estímulo para o crescimento mandibular e aumento do eixo condilar e do corpo mandibular maior que o crescimento normal, enquanto que o ângulo goníaco e o eixo facial não alteraram significativamente. Observaram ainda uma inclinação significante dos incisivos superiores para lingual, uma vestibularização dos incisivos inferiores, e uma mesialização dos molares inferiores, diante da comparação com o grupo controle. Identificaram um crescimento mandibular maior ros grupos que utilizaram aparelhos funcionais. O padrão das alterações dentoesqueléticas mostraram-se independentes do tipo de aparelho eleito, porém todos os aparelhos funcionais estudados promoveram um aumento no padrão facial no sentido vertical e a correção da má oclusão de Classe II, $1^{\text {a }}$ divisão.

A utilização do Bionator em jovens durante a fase de dentadura mista tardia propicia a correção da Classe II, por meio do estímulo do crescimento mandibular e pelas alterações dentárias e no perfil facial, além de proteger os dentes ânterosuperiores de possíveis fraturas. Neste contexto, TSAMTSOURIS; VEDRENNE ${ }^{150}$, em 1983, descreveram o aparelho com suas diversas modificações e apresentaram os efeitos que o Bionator proporciona sobre as estruturas dentoalveolares, esqueléticas e tegumentares. Os autores destacaram algumas possibilidades do mecanismo de ação do aparelho, sendo: (1) retração maxilar obtida por forças recíprocas diagonais entre os arcos, advindas por meio do reposicionamento anterior da mandíbula; (2) expansão transversal da maxila; (3) deslocamento distal dos dentes superiores; (4) deslocamento mesial dos dentes inferiores e inclinação anterior dos incisivos inferiores; (5) reposicionamento anterior mandibular; (6) 
irrupção passiva dos dentes com aumento da altura dos processos alveolares que contribuem para abertura da mordida e aumento da altura facial inferior; (7) rotação do plano oclusal e nivelamento da curva de Spee; e (8) correção da relação molar de Classe II por meio da prevenção da irrupção dos molares superiores, propiciada pela cobertura de acrílico sobre estes dentes. A ausência de contato do acrílico com os molares inferiores permite o deslocamento mesial destes, corrigindo a relação molar.

JANSON; HASUND ${ }^{81}$, em 1983, descreveram os resultados de um estudo com jovens pré-adolescentes e adolescentes tratados com o Bionator, do tipo adaptado por Ascher (1977), analisando o comportamento das mensurações esqueléticas e dentoalveolares. O grupo controle constava de 73 jovens, divididos em dois subgrupos de ortognatas e retrognatas, da mesma forma que o grupo experimental. Além disso, os jovens foram divididos em pré-pubertários e pubertários. Os resultados mostraram que não houve alterações esqueléticas significantes, enquanto que as alterações dentoalveolares predominaram no grupo experimental. Verificaram uma diminuição do ângulo interincisivos, decorrente da inclinação para lingual dos incisivos superiores e inclinação para vestibular dos inferiores. As alterações esqueléticas foram mais significantes na fase pubertária para ambos os grupos tratados e grupo controle. $O$ aparelho promoveu maior efeito dentoalveolar durante o período pré-pubertário, possibilitando sua indicação precoce em casos com má oclusão severa.

Advogando que a má oclusão de Classe II esquelética pode ser considerada como uma falha do processo de coordenação responsável pela harmonia do sistema estomatognático, BASS ${ }^{19,20}$, em 1983, desenvolveu uma técnica ortopédica e um sistema de aparelhos, com o fim precípuo de melhorar os fatores responsáveis pelo desenvolvimento da mencionada má oclusão, na fase inicial de tratamento. A melhora ocorreria pela restrição e redirecionamento do crescimento maxilar para anterior e um aumento na velocidade do crescimento mandibular. Assim, o tratamento eliminaria ou melhoraria as influências adversas do tecido mole. Subseqüentemente, instalaria o aparelho fixo da técnica Edgewise, para a finalização da correção da má oclusão. Deste modo, o autor descreveu os efeitos da 
restrição do crescimento maxilar e as alterações dentárias promovidas por uma placa de acrílico removível associada à ancoragem extrabucal. Devido às limitações desta forma de tratamento, utilizou também um aparelho ortopédico funcional, semelhante ao ativador, objetivando uma intensificação do crescimento mandibular. Com a fase ortopédica, BASS ${ }^{19,20}$ observou algumas vantagens no tratamento da Classe II esquelética, como uma aparência facial mais agradável, alcançada pela coordenação do crescimento maxilomandibular, uma coordenação precoce da musculatura bucofacial, uma diminuição ou minimização de cirurgias ortognáticas, o início do tratamento fixo numa época mais precoce, uma redução de casos com necessidade de extrações e uma alteração na relação muscular com os incisivos inferiores, permitindo que estes dentes movimentem-se para uma posição de equilíbrio, reduzindo o risco de uma subseqüente recidiva.

As limitações das análises cefalométricas proporcionam grandes controvérsias quanto a natureza das alterações decorrentes do tratamento com o ativador, pois dificultam a mensuração e a quantificação dos componentes envolvidos, se dentários ou esqueléticos. Assim sendo, PANCHERZ ${ }^{121}$, em 1984, propôs um método de análise cefalométrica para averiguar o mecanismo de correção da Classe II, utilizando o ativador. A amostra constou de 30 jovens, sendo 15 do gênero masculino e 15 do feminino, com média de idade de 10 anos e 10 meses, apresentando uma má oclusão de Classe II, 仾 divisão, tratados com 0 ativador. Como grupo controle, utilizou 16 jovens do gênero masculino e 16 do gênero feminino, todos com oclusão normal (padrão Bolton) aos 11 e 14 anos. Os resultados obtidos derivaram de telerradiografias em norma lateral, posicionando o paciente em relação cêntrica, antes e após o tratamento. Verificou que a correção das relações oclusais ântero-posteriores decorreram de modificações dentárias e esqueléticas em proporções similares, entretanto, com ampla variação individual. $A$ correção do trespasse horizontal ocorreu principalmente pelo maior crescimento mandibular em relação à maxila, e pela movimentação para lingual dos incisivos superiores. Comparando-se o grupo tratado e o grupo controle, observou que o tratamento induziu uma inibição do crescimento maxilar, uma verticalização dos incisivos superiores, mesialização dos molares inferiores e vestibularização dos 
incisivos inferiores. O crescimento mandibular parece não ter sido afetado pelo tratamento.

Estudando radiograficamente as alterações promovidas pelo tratamento com o ativador, o aparelho de Fränkel e o aparelho fixo da técnica Edgewise combinado com a ancoragem extrabucal, nas correções da Classe II, 1a divisão, REMMER et al. ${ }^{128}$, em 1985, selecionaram 3 amostras de 25 pacientes de acordo com cada aparelho utilizado. Os grupos tratados com o ativador e o aparelho de Fränkel incluíram jovens com idade inicial média de 10 anos e 3 meses, enquanto o grupo tratado com aparelho fixo combinado com a ancoragem extrabucal apresentou jovens com idade inicial média de 12 anos e 1 mês. Após a interpretação dos resultados concluíram que o avanço mandibular foi similar entre os grupos, sendo discretamente maior no grupo tratado com o ativador, porém com uma maior rotação da mandíbula no sentido posterior no grupo tratado com aparelho fixo. Este último grupo, também mostrou um efeito restritivo no avanço da maxila, efeito este, não visualizado nos outros dois grupos. Notaram ainda uma inclinação para lingual dos incisivos superiores, promovida pelos aparelhos funcionais, enquanto que o aparelho fixo propiciou um maior movimento de corpo dos incisivos superiores considerando a mesma direção referida. O perfil tegumentar experimentou pouca influência oriunda dos 3 aparelhos, exceto pela posição do lábio superior, que mostrou-se retruído no grupo com aparelho fixo, enquanto que no grupo tratado com aparelho de Fränkel, o lábio sofreu uma suave protrusão, apesar da inclinação dos incisivos superiores para lingual.

Acreditando que a harmonia do crescimento entre maxila e mandíbula pode ser obtida pela terapia com o Bionator de Balters nos casos de Classe II, ALTUNA; NIEGEL ${ }^{10}$, em 1985, descreveram os procedimentos para se obter uma correta mordida construtiva, asseverando ainda que este passo é o mais importante durante o tratamento ortopédico funcional. Demonstraram a manipulação clínica do Bionator, enfatizando os efeitos dos componentes do aparelho e a forma de desgastes do acrílico. Segundo os autores, deve-se iniciar os desgastes assim que os dentes decíduos forem esfoliados, entretanto na região anterior o acrílico deve ser mantido 
prevenindo a irrupção destes dentes. Finalizaram indicando o Bionator para jovens em crescimento apresentando má oclusão de Classe II com sobremordida, ou altura facial ântero-inferior normal e retrusão da mandíbula.

No mesmo ano, ROBERTS ${ }^{132}$, alicerçado na filosofia de Balters, destacou que a má oclusão de Classe II resulta da posição posterior da língua, gerando deglutição atípica e respiração bucal. Acreditava que o objetivo do tratamento consistia em avançar a língua por meio do avanço mandibular, estimulando a região posterior do dorso lingual pelo contato da alça palatina. Indicava o aparelho em jovens na fase de dentadura mista associada aos hábitos e função anormal da língua. Além disso, defendeu a utilização do aparelho como contenção noturna, após aparelhagem fixa e tratamento com o aparelho de Herbst.

Por meio de um estudo cefalométrico de 83 jovens, VARGERVIK; HARVOLD $^{160}$, em 1985, selecionaram 52 jovens tratados apenas com o ativador e 31 jovens tratados com o ativador numa primeira etapa e com o aparelho fixo numa fase subseqüente. As médias de idades encontravam-se numa faixa entre 10 anos e 7 meses para o gênero masculino e 10 anos e 2 meses para o gênero feminino. Verificaram, em ambos os grupos, a correção da Classe II, a verticalização dos incisivos superiores, uma redução significante no crescimento para anterior da maxila, um aumento da altura facial ântero-inferior, não havendo diferença significante no aumento do comprimento mandibular nem no reposicionamento do côndilo para anterior, entre os dois grupos tratados.

Com o desiderato de analisar o tratamento da Classe II, BOLMGREN; MOSHIRP7, em 1986 estudaram uma amostra de 20 casos tratados com o Bionator e finalizados com aparelho fixo, comparando-os com amostras de casos não tratados e um outro grupo, tratado somente com aparelho fixo. A amostra tratada com o Bionator apresentou 12 jovens do gênero masculino e 8 jovens do feminino, com idades variando de 9 a 14 anos. Os pacientes apresentavam má oclusão de Classe II, $1^{\text {a }}$ divisão com retrognatismo ou deficiência mandibular. Foram utilizadas duas amostras controle, sendo uma derivada da pesquisa de Riolo et al. composta 
por jovens de ambos os gêneros que não receberam tratamento e outra tratada somente com aparelho fixo. O tempo médio de tratamento com o Bionator foi de 12,7 meses, seguido de uma segunda fase com aparelho fixo que durou em média 15,9 meses. Os resultados demonstraram que não houve diferenças significantes entre as amostras, quanto às alterações esqueléticas da maxila, porém verificou-se um suave retrusão maxilar no grupo que utilizou o Bionator. Analisando-se a posição dos incisivos superiores, notourse uma verticalização e uma retrusão destes com a terapia do Bionator. Por outro lado, no grupo controle não se verificou estas alterações. Não houve alterações significantes quando da comparação dos 4 grupos para as medidas dos incisivos inferiores, porém ressalta-se que a cobertura de acrílico sobre os incisivos no grupo do Bionator preveniu a inclinação para vestibular destes dentes. De acordo com a manipulação clínica do Bionator, o ângulo do plano mandibular aumentou, devido à irrupção dos molares inferiores, enquanto que no grupo controle houve uma diminuição do ângulo do plano mandibular. $O$ comprimento mandibular do grupo do Bionator foi maior, comparado ao grupo tratado somente com aparelho fixo. A altura facial anterior aumentou quase duas vezes mais no grupo do Bionator que o aumento ocorrido no grupo não tratado. Verificou-se um maior aumento da altura dentária póstero-inferior no grupo do Bionator, comparado ao grupo não tratado, enquanto que o aumento observado no grupo do aparelho fixo não denotou diferença significante com o grupo tratado com o Bionator. Nenhuma diferença significante foi encontrada na altura dentária superior.

Em 1989, BISHARA; ZIAJA ${ }^{25}$ compulsaram extensamente a literatura pertinente ao tratamento das más oclusões de Classe II, 1a divisão, com os ativadores, os reguladores de função e os aparelhos fixos, segundo o mecanismo de ação, bem como a efetividade destes aparelhos. Após a pesquisa bibliográfica, ressaltaram que: 1- o aparelho funcional é apenas uma das modalidades efetivas no tratamento da Classe II; 2- os casos de Classe II, 1a divisão, ideais para a utilização de aparelhos funcionais seriam aqueles em que os pacientes se encontrassem na fase de crescimento, nos quais as extrações dentárias prejudicariam a estética facial, com os incisivos superiores protruídos e inferiores retruídos, com trespasse vertical acentuado, e com uma inclinação do plano mandibular de média a plana, e 
retrusão mandibular esquelética; 3- o sucesso do tratamento ortopédico depende da cooperação do paciente e da sua duração nos períodos de crescimento craniofacial; 4- os aparelhos ortopédicos devem ser utilizados por um período de tempo prolongado, geralmente de um ano e meio a dois anos, para assegurar uma completa adaptação condilar após o deslocamento inicial na cavidade glenóide; e 5a despeito do tipo de aparelho funcional utilizado, afirmaram que a correção da má oclusão ocorreria de maneira semelhante, ou seja, estimulando o crescimento mandibular, redirecionando o crescimento maxilar, inclinando os incisivos superiores para lingual, vestibularizando os incisivos inferiores, bem como promovendo uma erupção mesial e vertical dos molares inferiores e inibindo a erupção mesial dos molares superiores. A combinação dos efeitos dentoalveolares (60 a 70\%) e ortopédicos (30 a 40\%) permite a correção efetiva da má oclusão de Classe II. Além disso, a associação da tração alta extrabucal com os ativadores propicia um maior controle do crescimento vertical da maxila, melhorando conseqüentemente, 0 crescimento mandibular no sentido horizontal.

Interessados na avaliação dos efeitos do tratamento com o ativador em pacientes com Classe II, 1a divisão, com retrusão mandibular esquelética, CHANG et al. ${ }^{36}$, em 1989, selecionaram uma amostra de 9 pacientes do gênero masculino e 6 do gênero feminino, com média de idade de 9 anos e 5 meses. Utilizaram um grupo controle de 21 jovens do gênero masculino e 14 jovens do feminino com má oclusão similar a amostra anterior, e com média de idade de 9 anos e 6 meses. Os pacientes utilizaram o ativador num período de 14 horas por dia. Os autores evidenciaram uma redução dos trespasses horizontal e vertical, melhorando o perfil facial. Não verificaram alterações no complexo maxilar, avaliadas pelo ângulo SNA e pela medida A-NP. Os pacientes tratados com o ativador experimentaram um maior aumento dos ângulos Ar.GoMe e SNB e das medidas lineares Ar-Gn, AFAl e N-Me, indicando uma maior abertura do ângulo goníaco, um maior crescimento anterior da mandíbula, bem como um aumento das alturas faciais ântero-inferior e anterior total. Os ângulos ANB e NAP diminuíram sensivelmente melhorando o relacionamento maxilomandibular no grupo tratado. Os incisivos superiores e inferiores 
apresentaram-se, respectivamente, verticalizados e vestibularizados no grupo que recebeu o tratamento.

THÜER; INGERVALL; BÜRGIN ${ }^{147}$, em 1989, elaboraram um estudo objetivando identificar as possíveis alterações nas posições e nos movimentos mandibulares resultantes do uso do ativador. Utilizaram uma amostra composta por 21 jovens com média de idade de 10 anos e 1 mês, com má oclusão de Classe II, $1^{a}$ divisão, tratados com 3 tipos de ativadores: um ativador do tipo Herren, um ativador combinado com a ancoragem extrabucal e o ativador do tipo Andresen. A seleção destes tipos de ativadores ocorreu aleatoriamente para o grupo de pacientes. Para a verificação dos movimentos mandibulares e da posição de repouso dos contatos dentários durante a mastigação, utilizaram magnetos posicionados na superfície vestibular da margem gengival dos incisivos centrais inferiores. As mensurações das posições e dos movimentos mandibulares ocorreram antes e após um ano de tratamento. Após 245 dias do início do tratamento, observaram, por meio de telerradiografias em norma lateral, uma redução dos ângulos SNA e ANB de 0,3 e 0,9 graus, respectivamente e um aumento do ângulo SNB de 0,7 graus. Os incisivos superiores foram verticalizados, enquanto que os inferiores inclinaram-se para vestibular. Concluíram que o tratamento não provoca um posicionamento anterior da mandíbula nos períodos em que os ativadores não estão sendo utilizados. A posição ântero-posterior da mandíbula em repouso foi constante, mas o espaço funcional livre aumentou durante o tratamento.

A mordida construtiva desperta grande interesse nos pesquisadores quanto a quantidade de avanço realizado, e sua associação com um possível avanço condilar na fossa mandibular. Na literatura observa-se grande controvérsia sobre o assunto, sendo que alguns estudiosos asseveram um avanço mandibular progressivo, enquanto outros preconizam uma propulsão única, mantendo os incisivos de topo-atopo. Para avaliar os efeitos da mordida construtiva sobre o tratamento da Classe II, OP HEIJ et al. ${ }^{119}$, em 1989, estudaram uma amostra de jovens com Classe II, $1^{\text {a }}$ divisão utilizando o Bionator de Balters. Utilizaram 27 jovens, agrupados de acordo com a idade, gênero e tipo de má oclusão, sendo ainda subdivididos em 2 grupos de 
acordo com o tipo de mordida construtiva realizada. O primeiro grupo (Be) consistiu de 14 jovens que utilizaram um aparelho obtido em uma relação de topo-a-topo dos incisivos, e com uma abertura anterior de 2 a $4 \mathrm{~mm}$. O segundo grupo (Bmax) constituiurse de 13 jovens tratados com o Bionator construído em mordida de máxima protrusiva, ou seja, máximo avanço mandibular em que o paciente se sente confortável. Por meio de telerradiografias obtidas ao início e ao final de um ano de tratamento, os grupos foram comparados cefalometricamente. Observaram que a relação de topo-a-topo, foi superior à máxima protrusão, no que diz respeito ao crescimento do ramo ascendente mandibular. A diferença no crescimento do corpo da mandíbula relacionourse com o fator gênero, sendo maior nos jovens do gênero masculino. Após o tratamento, a posição do côndilo mandibular encontrava-se mais inferior e, possivelmente mais anterior, considerando-se o ponto $\mathrm{S}$ como referencial em ambos os grupos. O maior deslocamento do côndilo, verificado no grupo de avanço máximo da mordida pode explicar, parcialmente, o aumento no ângulo SNB e na altura facial anterior. A maior altura no ramo mandibular observada no grupo de avanço topo-a-topo, e o maior deslocamento inferior do côndilo no grupo com avanço máximo da mordida, foram atribuídos às diferentes quantidades de avanço mandibular, confeccionado na mordida construtiva.

Em 1990, DERRINGER ${ }^{45}$ comparou os efeitos do tratamento utilizando a tração cervical, com e sem extração, e o ativador do tipo Andresen, com as alterações num grupo controle. Para tanto, analisou telerradiografias em norma lateral, ao início, final de tratamento ativo e controle. Utilizou uma amostra de 30 pacientes tratados com o ativador e 40 pacientes com a tração cervical (com e sem extração) e um grupo controle composto de 22 pacientes não tratados. Constatou, por meio do ângulo SNA, uma redução estatisticamente significante quando da comparação do grupo tratado com o ativador e o grupo controle. Referenciando as alterações no sentido ântero-posterior da mandíbula, verificou, pelo ângulo SNB um significante e mais favorável deslocamento para anterior do ponto $\mathrm{B}$, no grupo tratado com o ativador, comparado ao grupo tratado com tração cervical sem extração. O comprimento mandibular total (Ar-Gn), aumentou mais no grupo tratado com o ativador, comparando-se com o grupo tratado com a tração cervical, sem 
extração. O comprimento do corpo mandibular (Go-Gn) mostrou um crescimento significantemente maior no grupo que utilizou o ativador em relação aos outros grupos estudados. O aumento no comprimento do ramo mandibular (Go-Ar) foi significante nos grupos tratados, em comparação ao grupo controle. Todos os grupos tratados experimentaram um aumento vertical anterior significante em relação ao grupo controle. O autor notou um maior aumento na altura facial ânteroinferior nos pacientes tratados com ortopedia funcional. Embora sem diferença significante, o ângulo ANB reduziu mais no grupo do ativador, principalmente pelo expressivo aumento do ângulo SNB. O aumento do ângulo NS.Gn em todos os grupos representou uma rotação mandibular para baixo e para frente, sendo o deslocamento para baixo não estável após o tratamento.

Neste mesmo ano, MAMANDRAS; ALLEN ${ }^{101}$ investigaram a resposta mandibular ao tratamento com o Bionator, em 40 pacientes com má oclusão de Classe II, 1a divisão. A amostra foi dividida em dois grupos, conforme a mudança horizontal do ponto Pogônio nas telerradiografias do início ao término do tratamento. Os jovens que experimentaram um deslocamento anterior do Pogônio menor que $3 \mathrm{~mm}$ constituíram o grupo de "pequeno avanço", enquanto que aqueles que apresentaram um avanço maior de $3,5 \mathrm{~mm}$ representaram o grupo de "grande avanço". A mordida construtiva foi elaborada com abertura de $3 \mathrm{~mm}$ além da posição de repouso e avanço mandibular de $3 \mathrm{~mm}$ aquém da máxima protrusão. Recobriurse a borda incisal dos incisivos inferiores com acrílico para evitar a sua protrusão. Os autores concluíram que pacientes com mandíbula pequena se beneficiam mais do que aqueles com mandíbulas de tamanho normal, quando tratados com o Bionator. Os pacientes que apresentam crescimento tardio podem experimentar mais desenvolvimento que aqueles com desenvolvimento mediano, durante o tratamento, em função do ambiente favorável de crescimento propiciado pela terapia com o aparelho funcional.

O aparelho ativador vem sendo extensamente indicado para a correção da Classe II, 1a divisão, uma vez que diversas pesquisas denotam uma influência no padrão de desenvolvimento das estruturas dentoesqueléticas da face, bem como no 
padrão de crescimento e no posicionamento mandibular. As controvérsias existentes quanto ao modo de ação, se restrito às alterações dentoalveolares ou esqueléticas com estímulo do crescimento mandibular, despertaram o interesse de JAKOBSSON; PAULIN ${ }^{77}$ (1990), em avaliar a influência do tratamento com o ativador sobre o crescimento esquelético-facial em jovens com más oclusões de Classe II, 1 a divisão. A amostra constituiu-se de 53 jovens com Classe II, $1^{\underline{a}}$ divisão, sendo 31 jovens do gênero feminino com idade inicial média de 10 anos e 9 meses e 22 jovens do masculino com idade inicial média de 11 anos e 6 meses. Utilizaram um grupo controle de 60 jovens com Classe II, 1a divisão que não receberam tratamento, para as devidas comparações das grandezas cefalométricas. Assim, analisaram telerradiografias em norma lateral, no início e no final do tratamento. Observaram uma diminuição significante do ângulo ANB no grupo tratado com o ativador, destacando que os jovens do gênero feminino experimentaram uma redução do crescimento para anterior da maxila, enquanto que os jovens do gênero masculino apresentaram um maior crescimento para anterior da mandíbula. Verificaram que o ativador proporcionou uma redução do crescimento para anterior do ponto $A$ em ambos os jovens, porém mais pronunciado entre os jovens do gênero feminino. $A$ altura facial anterior total, visualizada pela distância linear N-Me aumentou significantemente no grupo tratado. Salientaram ainda que o comprimento efetivo mandibular (Co-Gn) sofreu aumento nos jovens de ambos os gêneros do grupo tratado com o ativador. A direção de crescimento alterou-se com maior intensidade no sentido vertical nos jovens do gênero feminino tratados com o ativador, enquanto que nos jovens do gênero masculino houve um maior deslocamento para anterior. $O$ plano mandibular não foi alterado significantemente, não obstante tenha ocorrido um aumento da altura facial anterior total.

Na tentativa de estudar os fatores que podem conduzir a recidiva da correção do trespasse horizontal utilizando aparelhos funcionais, DRAGE; HUNT ${ }^{47}$, em 1990, utilizaram 49 jovens tratados com ativador de Andresen ou com o Bionator. A idade inicial média destes jovens foi de 12,1 $\pm 1,1$ anos, onde analisaram as alterações do tratamento e pós-tratamento, por meio de telerradiografias em norma lateral. Utilizou-se um grupo controle de 24 jovens, para comparar as alterações do 
tratamento, com idade inicial média de 11,8 $\pm 0,5$ anos. Os autores concluíram que a redução do trespasse horizontal ocorreu principalmente como resultado de alterações dentoalveolares. As alterações das inclinações dos incisivos superiores para vestibular e em menor grau, dos incisivos inferiores para lingual, contribuíram para a recidiva do trespasse horizontal. Não houve evidências de que um padrão de crescimento vertical pudesse influenciar na recidiva dos casos tratados. Entretanto, verificourse que, os jovens que sofreram uma grande redução do trespasse horizontal durante o tratamento experimentaram maior recidiva pós-tratamento. Não obstante, a inclinação vestibular dos incisivos superiores após o tratamento tenha sido associada com a quantidade de inclinação para lingual destes durante a fase de tratamento, não se verificou nenhuma relação entre as alterações de tratamento e pós-tratamento na inclinação dos incisivos inferiores.

Em 1991, DE VINCENZO44 analisou as alterações no comprimento mandibular antes, durante e após o sucesso da correção ortopédica da má oclusão de Classe II, utilizando um tipo de aparelho funcional proposto por ele e colaboradores. A amostra constituiurse de 47 jovens do gênero feminino, tratados numa primeira fase com 0 aparelho funcional $e$, em seguida, submetidos ao tratamento com aparelho fixo da técnica Edgewise. As telerradiografias em norma lateral foram obtidas ao início do tratamento, ao final da fase ortopédica, ao final do tratamento com aparelhagem fixa, ao final do período de contenção e em controles periódicos. Utilizou um grupo controle de 47 pacientes não tratados, pertencentes ao Centro de Crescimento de Burlington, com más oclusões de Classe I e Classe II. A análise cefalométrica utilizou a medida linear Ar-Pog com a finalidade de verificar estatisticamente as alterações no comprimento mandibular. Verificou de acordo com os resultados, um aumento inicial marcante no comprimento mandibular durante a fase ortopédica. No entanto, durante a fase pós-ortopédica e a de aparelho fixo, a velocidade de crescimento mandibular diminuiu significantemente em relação aos pacientes do grupo controle. A quantidade de crescimento no comprimento mandibular, desde a instalação do aparelho até o período de controle final, permaneceu similar entre os dois grupos. Concluiu ainda que o comprimento mandibular aumenta de modo significante até 2 anos após o final do tratamento, 
diminuindo mas considerado ainda significante após 3 anos, e não ocorrendo diferenças significantes após o quarto ano de controle.

Ainda no ano de 1991, HASHIM ${ }^{65}$ estudou cefalometricamente 36 jovens (25 do gênero feminino e 11 do masculino), com média de idade de 12 anos e 2 meses, tratados com ativadores, por um período médio de 10 meses. Utilizou um método de sobreposição de telerradiografias para determinar o movimento dos molares, a modificação intermaxilar e a influência individualizada sobre as bases ósseas maxilar e mandibular. Os resultados apontaram que os principais efeitos encontrados foram dentoalveolares, não obstante tenha observado um pequeno efeito ortopédico na maxila. A mandíbula não experimentou um crescimento significante em relação ao crescimento mandibular esperado naturalmente.

Compulsando a literatura pertinente ao tratamento da má oclusão de Classe II, MILLS ${ }^{111}$ em 1991, revisou 26 artigos referente aos aparelhos ativador do tipo Andresen ou o regulador de função de Fränkel. Com a combinação dos artigos o autor constituiu uma extensa amostra e comparou com um grupo controle de pacientes Classe II, 1a divisão não tratados, originados das amostras citadas nos artigos estudados. O autor não encontrou nenhuma evidência de restrição do crescimento maxilar para anterior pelo uso de aparelhos funcionais, considerando a espinha nasal anterior como ponto de referência. Ocorreu uma discreta diminuição do ângulo SNA, que resultou de um movimento para lingual dos incisivos superiores. A mandíbula apresentou um maior crescimento nos casos tratados com o Fränkel e mais moderado com o ativador, principalmente com relação à dmensão vertical; considerando a região do pogônio, os grupos experimentais e controle reagiram similarmente. O aumento do crescimento mandibular em pacientes tratados com outros tipos de aparelhos foi semelhante, devido à seleção de apenas resultados positivos. Ressaltou também a extensa variabilidade individual das respostas aos tratamentos. Contudo, verificou uma consistência entre os resultados obtidos nos diferentes trabalhos, apesar da diversidade de origem destes. 
Interessados em determinar as alterações na posição e no tamanho mandibular, NELSON; HARKNESS; HERBISON ${ }^{115}$ (1993) analisaram 42 jovens, apresentando má oclusão de Classe II, 1a divisão, com média de idade de 11 anos e 6 meses, triados de acordo com a idade e gênero, compatíveis a um grupo controle, não havendo diferenças significantes entre os grupos ao início do estudo. As amostras utilizaram 2 tipos de aparelhos funcionais, o ativador de Harvold (17 casos) e o regulador de função de Fränkel (16 casos), durante um período de 18 meses. Obteve-se telerradiografias em norma lateral ao início, 6 meses, 12 meses e 18 meses de tratamento. Após este último período, justificaram os aumentos significantes no ângulo goníaco e no comprimento Ar-Pog, no grupo tratado com o ativador, devido a alteração de posição do ponto Articular, proveniente de um posicionamento ântero-inferior do côndilo ao final do tratamento. Os efeitos principais decorrentes de ambos aparelhos consistiram na liberação da erupção dos molares inferiores e no aumento da altura facial. $O$ ativador também causou a inclinação para vestibular do incisivos inferiores e um aumento do comprimento do arco. Não encontraram nenhuma evidência que confirmasse a capacidade dos referidos aparelhos de alterar o tamanho da mandíbula.

Objetivando a determinação dos efeitos do Bionator sobre a morfologia dentoesquelético-facial, LANGE et al. $^{94}$, em 1995, utilizaram uma amostra de 30 jovens com Classe II, $1^{\text {a }}$ divisão, e idades variando entre 9 e 12 anos tratados por 18 meses com o Bionator. O aparelho utilizado foi uma variação daquele preconizado por Balters, uma vez que o acrílico recobria os incisivos inferiores. Confeccionourse a mordida construtiva numa relação de topo-a-topo dos incisivos e abertura de 4 a 5 $\mathrm{mm}$ na região dos molares. Utilizou-se um grupo controle compatível com a idade e gênero da amostra tratada. Comparando-se os dois grupos, verificou-se no grupo tratado uma diminuição significante do ângulo SNA, porém analisando a medida CoENA não se verificou diferença entre os dois grupos. Concluíram que o Bionator produz um suave efeito de restrição do crescimento anterior da maxila. Por outro lado, notou-se um aumento significante no comprimento efetivo mandibular (Ar-Gn) e no ângulo SNB. Deste modo, houve uma diminuição do ângulo ANB de $1,97^{\circ}$. As alturas faciais anterior e posterior aumentaram significativamente, enquanto que 0 
ângulo FMA não apresentou diferença entre os grupos. A convexidade facial diminuiu significantemente no grupo tratado. Não houve diferença significante entre os grupos, na avaliação do ângulo nasolabial. Os resultados aludiram um aumento no ângulo mentolabial de $17,4^{\circ}$. O lábio superior sofreu mínimo efeito com a terapia do Bionator.

Utilizando uma associação entre as alterações nas dimensões faciais e o resultado do tratamento com aparelhos funcionais, WEBSTER; HARKNESS; HERBISON $^{163}$, em 1996, compilaram uma amostra de 42 jovens, apresentando má oclusão de Classe II, 1a divisão, com média de idade de 11 anos e 6 meses, triados de acordo com a idade e gênero compatíveis a um grupo controle, não havendo diferenças significantes entre os grupos ao início do estudo. Propuseram um índice denominado PAR (Peer Assessment Rating), para verificar o sucesso do tratamento pela avaliação em modelos de estudo e por meio de telerradiografias em norma lateral. A amostra utilizou aparelhos funcionais do tipo ativador de Harvold e regulador de função de Fränkel, tratados durante um período de 18 meses. Correlacionaram alterações significantes entre o aumento das alturas faciais anterior total, ântero-inferior, posterior, inclinação inferior da maxila e do corpo mandibular com o sucesso do tratamento. A indicação de sucesso no tratamento também associou-se significantemente com uma restrição maxilar, redução no ângulo ANB e com o comprimento maxilar. Um aspecto interessante abordado foi que, não obstante o comprimento mandibular tenha aumentado significantemente no grupo tratado quando comparado ao controle, não houve uma correlação significante associada com o sucesso do tratamento. Asseveraram ainda que as alterações no ponto B ocorreram em função da inclinação para vestibular dos incisivos inferiores.

Com a finalidade de determinar as alterações na posição da maxila e na base do crânio após o tratamento com o ativador de Harvold e o regulador de função de Fränkel, COURTNEY; HARKNESS; HERBISON ${ }^{38}$, em 1996, analisaram 42 jovens, apresentando má oclusão de Classe II, 1a divisão, com média de idade de 11 anos e 6 meses, triados de acordo com a idade e gênero compatíveis a um grupo controle, não havendo diferenças significantes entre os grupos ao início do estudo. A amostra 
utilizou aparelhos funcionais do tipo ativador de Harvold e regulador de função de Fränkel, durante um período de 18 meses. Obteve-se telerradiografias em norma lateral ao início, 6 meses, 12 meses e 18 meses de tratamento. Avaliaram unicamente da fase inicial à fase final de tratamento (18 meses), verificando um aumento da altura facial anterior e uma redução do trespasse horizontal, resultante da verticalização dos incisivos superiores, diminuindo sobremaneira o comprimento do arco superior, sendo este resultado mais acentuado no grupo que utilizou o ativador. Os resultaram denotaram que não houve alterações estatisticamente significantes na posição dos pontos ENA, ENP e A, indicando que ambos os aparelhos não afetaram a posição da maxila. Identificaram alterações de pequena intensidade na região do ponto básio, porém estatisticamente significantes, nos pacientes tratados com o Fränkel, comparando-se com ambos os grupos, ativador e controle. Esta pequena alteração no ponto básio pode ser atribuída às grandes alterações na base do crânio dos pacientes estudados, influenciando os resultados baseados na pequena amostra averiguada.

Com o intuito de comparar os efeitos esqueléticos e dentários de 3 tipos de aparelhos ortopédicos funcionais, CURA et al. ${ }^{41}$, em 1996, utilizaram o aparelho ativador, o aparelho de Bass e o ativador combinado com a ancoragem extrabucal para o tratamento da Classe II, 1a divisão em 64 pacientes. Os autores evidenciaram uma melhora significante na relação maxilomandibular, observada pela redução do ângulo ANB, nos 3 grupos estudados. Contudo, verificaram que o aparelho de Bass proporcionou um maior controle da inclinação dos incisivos superiores e inferiores, reduzindo deste modo, a verticalização e a vestibularização, respectivamente. Da mesma forma, o aparelho ativador combinado com a ancoragem extrabucal, favoreceu o controle da inclinação para vestibular dos incisivos inferiores.

Considerando que o Bionator de Balters exerce alterações ao nível dentário, esquelético e no perfil facial, FREITAS ${ }^{57}$, em 1996, realizou um estudo para avaliar os efeitos esqueléticos e dentários no tratamento da Classe II, $1^{\mathrm{a}}$ divisão com 0 Bionator. Para tanto, utilizou uma amostra de 16 jovens, todos do gênero feminino, na faixa etária entre 7 anos e 10 meses e 9 anos e 2 meses de idade, apresentando 
má oclusão de Classe II, $1^{\mathrm{a}}$ divisão com retrognatismo mandibular. Após a análise dos resultados concluiu que: 1-o Bionator proporcionou um aumento significativo do comprimento efetivo da mandíbula, porém não houve rotação mandibular; 2-não houve alteração significativa da posição do incisivo inferior em relação ao plano mandibular, porém os incisivos superiores inclinaram-se para lingual; 3-houve extrusão significante dos primeiros molares superiores e inferiores; 4-a posição do lábio inferior em relação à linha $E$ de Ricketts se manteve inalterada; 5-quanto maior a AFAl inicial, menor o aumento do comprimento mandibular, e, quanto menor a AFAl inicial, maior o aumento do comprimento mandibular; e 6-quanto menor a AFP inicial, menor o aumento do comprimento mandibular, e, quanto maior a AFP inicial, maior o aumento do comprimento mandibular.

A interceptação precoce da má oclusão de Classe II, tem sido objeto de intenso estudo por parte dos pesquisadores, pois a possibilidade de alteração do crescimento craniofacial durante a fase de dentadura mista torna-se extremamente importante. Defendendo a intervenção precoce nas más oclusões de Classe II, TULLOCH et al. ${ }^{154}$, em 1997, estudaram e compararam os efeitos do aparelho extrabucal e do Bionator de Balters sobre o padrão esquelético desta má oclusão. Para tanto, utilizaram um grupo controle de jovens apresentando má oclusão de Classe II que não utilizaram nenhum aparelho e foram observados por 15 meses. Os 3 grupos apresentaram idade inicial média de 9,4 anos, e não se verificou diferença significante na medidas cefalométricas iniciais entre os grupos. Verificaram uma melhora significativa da Classe II nos grupos tratados, com redução significante do ângulo ANB. Entretanto, o mecanismo de redução do ANB não foi semelhante para os dois grupos tratados, sendo que os jovens que utilizaram o aparelho extrabucal apresentaram uma restrição do crescimento anterior da maxila. Por outro lado, notaram um maior aumento no comprimento mandibular nos jovens que utilizaram o Bionator. Concluíram que o tratamento precoce da Classe II, utilizando tanto o aparelho extrabucal como o aparelho funcional, proporciona $75 \%$ de chance de melhora no padrão maxilomandibular. 
No mesmo ano, TULLOCH; PROFFIT; PHILLIPS ${ }^{152}$ (1997) estudaram a influência nos resultados obtidos pelo tratamento precoce da má oclusão de Classe II, utilizando 3 grupos de jovens na fase de dentadura mista. O grupo controle apresentava 61 jovens com média de idade de 9,4 anos, sendo acompanhados por um período de 15 meses, sem receber nenhum tratamento. $O$ grupo que utilizou o aparelho extrabucal compunha-se de 52 jovens com média de idade de 9,4 anos, acompanhados também por um período de 15 meses. Os 53 jovens que utilizaram o Bionator modificado foram acompanhados por 15 meses, e apresentavam idade inicial média de 9,4 anos. Concluíram que as alterações no relacionamento maxilomandibular (ANB) foram favoráveis ou altamente favoráveis em $76 \%$ dos pacientes que utilizaram o aparelho extrabucal, $83 \%$ nos pacientes que usaram o Bionator e $31 \%$ no grupo controle.

Ainda no ano de 1997, HENRIQUES et al. ${ }^{71}$ demonstraram por meio de um caso clínico, a aplicação da terapia com o Bionator para a correção das discrepâncias esqueléticas em uma primeira fase, e posteriormente a instituição de aparelhagem fixa para correção de problemas de origem dentários. Assim, com a combinação do tratamento ortopédico-ortodôntico conseguiu-se a normalização da relação das bases ósseas, promovendo uma melhora na estética facial. Analisando as alterações cefalométricas, verificaram um aumento no ângulo SNB e no comprimento mandibular efetivo (Co-Gn), o que propiciou uma melhora na relação ântero-posterior das base apicais (ANB). Não observaram restrição do crescimento maxilar (SNA) e (Co-A), mas a altura facial ântero-inferior experimentou um aumento significante. Concluíram, ressaltando a importância da indicação do Bionator em jovens com padrão de crescimento equilibrado, bem como aplicação desta terapia em pacientes colaboradores.

A controvérsia existente na literatura quanto à época de intervenção das más oclusões de Classe II ainda continua sendo assunto de grande interesse, bem como a instituição de uma única fase tardia de tratamento ou duas fases, sendo uma precoce e outra tardia. Deste modo, TULLOCH; PHILLIPS; PROFFIT ${ }^{153}$, em 1998, propuseram um estudo sobre os benefícios do tratamento precoce da Classe II, 
dividindo-o em duas fases. A amostra constou de 166 jovens na primeira fase do estudo e de 147 que continuaram na segunda fase. Utilizaram 3 grupos para as devidas comparações, sendo um controle de 61 jovens, 53 que foram tratados com o Bionator e 52 tratados com o aparelho extrabucal durante um período de 15 meses. Verificaram uma melhora no relacionamento esquelético das bases ósseas em $5 \%$ dos jovens do grupo controle, enquanto que 15\% destes mostraram uma piora marcante. Analisando os efeitos do tratamento com o Bionator e com o aparelho extrabucal, concluíram que ambas as estratégias reduziram a gravidade da discrepância esquelética das bases ósseas, evidenciada por uma redução significante do ângulo ANB. Entretanto, o mecanismo que propiciou esta melhora da Classe II foi diferente em ambos os grupos, em função de uma restrição do crescimento maxilar anterior, proporcionada pelo extrabucal e um maior aumento do comprimento mandibular com deslocamento anterior do mento evidenciado no grupo tratado com o Bionator. Finalizaram ressaltando que a severidade inicial da má oclusão de Classe II, bem como o tempo de tratamento não são fatores importantes nos resultados finais. A variabilidade no padrão de crescimento esquelético parece ser o grande contribuinte para as grandes variações nas diferentes respostas do tratamento.

Em 1998, JANSON; NOACHTAR ${ }^{80}$ asseveraram os diversos efeitos do tratamento com o Bionator, ressaltando que as principais alterações enquadram-se nas adaptações dentoalveolares. Mencionaram 3 fatores que devem ser levados em consideração para indicação do Bionator: 1-o paciente deve apresentar um padrão de crescimento favorável, com rotação mandibular anterior e moderada discrepância esquelética; 2-a morfologia individual e os objetivos do tratamento funcional devem ser obtidos por meio de guias individuais e não de valores médios propostos; e 3indicação do Bionator nos casos de hábitos parafuncionais, respiração bucal e sobremordida. Concluindo, os autores ressaltam que os pré-requisitos para um tratamento eficiente utilizando o Bionator incluem a seleção do paciente, baseada na morfologia individual e padrão de crescimento, bem como a construção precisa do aparelho. 
ALMEIDA et al. ${ }^{5}$, em 1998, publicaram um estudo cefalométrico comparativo dos efeitos dos aparelhos ativador combinado ao extrabucal e Fränkel no tratamento da Classe II, $1^{\text {a }}$ divisão. Utilizaram 47 jovens, 25 para o grupo tratado com o ativador com extrabucal e 22 com o aparelho de Fränkel. Verificaram que o ativador possibilitou uma restrição do crescimento anterior da maxila enquanto que o Fränkel promoveu maiores alterações ao nível mandibular, com aumento do comprimento efetivo e do corpo. Não notaram diferenças significantes nos pacientes tratados por ambos os aparelhos no padrão de crescimento facial, não obstante verificourse um maior aumento da altura facial ântero-inferior com o ativador. Analisando a posição dentária aludiram uma maior inclinação dos incisivos inferiores para vestibular com o aparelho de Fränkel e uma resposta similar dos aparelhos quanto a lingualização dos incisivos superiores.

Com o desiderato de comparar os resultados de três investigações clínicas casuais as quais utilizaram tratamentos alternativos da má oclusão de Classe II, $1^{\text {a }}$ divisão, GHAFARI; KING; TULLOCH ${ }^{61}$, em 1998, compilaram os achados dos estudos das Universidades da Carolina do Norte, Flórida e da Universidade da Pensilvânia. Para tanto, foram utilizados aparelhos funcionais (Bionator e Fränkel) e aparelhos extrabucais. Os resultados da Universidade da Carolina do Norte (UNC) demonstraram que os aparelhos Bionator e extrabucal promoveram uma redução significante da discrepância esquelética em comparação com o grupo controle. $O$ aparelho extrabucal mostrourse mais efetivo sobre o complexo maxilar, promovendo um maior efeito restritivo do crescimento da maxila (SNA). O Bionator denotou efeito semelhante ao grupo controle, ou seja, não atuou restringindo o crescimento maxilar. Por outro lado, o Bionator promoveu um maior deslocamento anterior da mandíbula (SNB) e um maior aumento no comprimento mandibular, em comparação aos grupos controle e extrabucal. Os resultados encontrados pela Universidade da Flórida, denotaram que tanto o aparelho extrabucal como o Bionator atuaram de maneira semelhante sobre a maxila em comparação ao grupo controle; porém o extrabucal promoveu maior distalização dos molares superiores. Analisando a posição mandibular, tanto o extrabucal quanto o Bionator responderam de forma semelhante deslocando-a anteriormente com maior intensidade que o grupo controle. Os 
resultados divulgados pela Universidade da Pensilvânia demonstraram que o extrabucal propiciou uma maior restrição do crescimento anterior da maxila (SNA), em comparação com o aparelho de Fränkel. Os molares foram distalizados com maior intensidade no grupo que utilizou o extrabucal. Notaram que o aparelho de Fränkel possibilitou um maior deslocamento anterior da mandíbula. Entretanto, o comprimento mandibular encontrado utilizando ambos os aparelhos foi semelhante.

Destacando as principais características do Bionator de Balters, FALTIN; FALTIN JÚNIOR ${ }^{50}$, em 1998, afirmaram que este aparelho é considerado ortopédico funcional, uma vez que atua treinando a musculatura peribucal e necessitando de verdadeira ginástica muscular. Além disso, o Bionator visa a normalização funcional, a alteração postural da mandíbula em relação à maxila, devolvendo ao aparelho estomatognático estímulos normais de crescimento e desenvolvimento, dando-lhes condições para normalização, por meio de forças próprias do organismo. Esta terapia preocupa-se, portanto, com o equilíbrio das estruturas faciais aos dentes relacionados, para que o equilíbrio final do aparelho mastigatório possa ser alcançado.

Ainda no ano de 1998, ILLING; MORRIS; LEE ${ }^{75,112}$ publicaram dois artigos avaliando os efeitos de aparelhos ortopédicos (Bionator, Bass e Twin Block) sobre as estruturas dentoesqueléticas e tegumentares. A amostra compreendeu 47 pacientes tratados com um dos três aparelhos referidos e foi comparada a um grupo controle não tratado. O Bionator e o Twin Block produziram um aumento significante no comprimento mandibular e uma diminuição na inclinação dos incisivos superiores. A altura facial inferior aumentou em todos os grupos tratados. Quanto às alterações do tecido mole observaram um aumento no comprimento e protrusão do lábio inferior e aumento na altura facial total e inferior em todos os grupos tratados com os aparelhos referenciados. Os autores asseguraram que o Bionator e o Twin Block apresentaram maior efetividade, produzindo maiores alterações sagitais e verticais.

Um dos poucos estudos sobre a magnitude das forças intermaxilares produzidas por aparelhos ortopédicos foi conduzido em 1999 por KATSAVRIAS; 
HALAZONETIS ${ }^{86}$. Os autores mensuraram, durante 6 meses, a magnitude da força induzida pelo uso do ativador. Os resultados indicaram uma extensa variabilidade entre os indivíduos e entre os períodos de avaliação. A força média observada foi de 100 gramas, considerada força ortodôntica.

Com o propósito de determinar a atratividade nos perfis de jovens com Classe II, 1a divisão, tratados com ativador e aparelho de Fränkel e em jovens não tratados, O'NEILL; HARKNESS; KNIGHT ${ }^{118}$, em 2000, avaliaram a opinião de estudantes de arte, alunos de odontologia e dos pais de pacientes ortodônticos. Primeiramente foi verificado se o perfil ao início ou após 18 meses de terapia ortopédica era mais atraente. Observaram que não houve diferença estatiscamente significante entre a opinião dos avaliadores, os quais não denotaram maior atratividade dos perfis tratados em relação aos não tratados. Assim, os autores concluíram que o tratamento com aparelhos ortopédicos não produz um perfil facial mais agradável que nos casos não tratados.

No mesmo ano (2000) ALMEIDA ${ }^{3}$, com o propósito de comparar as alterações dentoalveolares, esqueléticas e faciais produzidas pelos aparelhos Fränkel e Bionator na correção da Classe II, 1aㅡ divisão, conduziu uma pesquisa em 66 pacientes. A amostra foi dividida em três grupos de 22, sendo 11 do gênero masculino e 11 do feminino. Os jovens do grupo 1 foram mantidos como controle e apresentaram uma idade inicial média de oito anos e sete meses. O grupo 2, foi submetido ao tratamento utilizando o aparelho de Fränkel, com idade inicial média de nove anos. O grupo 3 foi tratado com o Bionator de Balters, com idade inicial média de dez anos e oito meses. Para cada jovem corresponderam duas telerradiografias, obtidas ao início e no final do período de acompanhamento. Os resultados demonstraram que os aparelhos referidos não promoveram alterações no desenvolvimento maxilar. No entanto, produziram um aumento na protrusão mandibular e nos comprimentos efetivo e do corpo da mandíbula, com valores maiores para o grupo 3. A relação maxilomandibular melhorou significantemente nos grupos tratados em comparação ao grupo controle. A análise do padrão de crescimento craniofacial não revelou alteração significante entre os grupos. A altura 
facial ântero-inferior não denotou alteração significante, porém no grupo 3, a altura facial posterior aumentou significantemente. As alterações dentoalveolares demonstraram que os incisivos superiores e inferiores inclinaram-se, respectivamente, para lingual e para vestibular nos grupos tratados. Os molares inferiores apresentaram um maior desenvolvimento vertical nos grupos 2 e 3 . Os aparelhos de Fränkel e Bionator promoveram uma retrusão do lábio superior e uma protrusão do lábio inferior.

Em 2001, AHN; KIM; NAHM ${ }^{1}$ objetivaram identificar as características cefalométricas dos pacientes que apresentaram sucesso na correção da má oclusão de Classe II, 1a divisão com uso do Bionator na fase da dentadura mista. Como objetivo adicional, os autores buscaram justificar o tratamento precoce desta má oclusão. A amostra constou de 40 pacientes tratados com o Bionator por um período médio de 20,8 meses, com média de idade de 10,4 anos, que foram divididos em dois grupos. Um grupo que apresentou bons resultados após a terapia e outro que obteve resultados não tão satisfatórios na fase pós-ortopédica. Os critérios para divisão dos grupos incluíram relação molar, trespasse horizontal e vertical, perfil tegumentar e a recidiva pós-tratamento. Os resultados demonstraram que em ambos os grupos, a mandíbula movimentou-se para frente e para baixo, os incisivos superiores retruíram e os inferiores protruíram. O padrão cefalométrico que respondeu melhor ao tratamento com o Bionator foi identificado assim: crescimento horizontal, relação sagital entre os maxilares próxima do normal, incisivos inferiores verticalizados e retrusão do lábio inferior. Os autores afirmaram que a indicação do Bionator e a eficiência do tratamento estão intimamente relacionadas às características morfológicas faciais dos pacientes.

LUX et al. ${ }^{97}$, em 2001, avaliaram as alterações dentofaciais produzidas pelo ativador no tratamento da má oclusão de Classe II, 1a divisão em jovens do gênero masculino com idade entre 9,5 anos e 11,5 anos. Os 20 jovens tratados foram comparados a um grupo de 15 jovens com má oclusão semelhante que não receberam tratamento ortodôntico. Os autores observaram que o tratamento com o ativador reduziu o trespasse horizontal, por meio das inclinações dos incisivos 
superiores para lingual e dos inferiores para vestibular, e promoveu uma protrusão mandibular.

Com o propósito de comparar as alterações dentoalveolares e esqueléticas produzidas pelos aparelhos Fränkel e Bionator na correção da Classe II, $1^{a}$ divisão, ALMEIDA; HENRIQUES; URSF', em 2002 avaliaram 66 pacientes. A amostra foi dividida em três grupos de 22, sendo 11 do gênero masculino e 11 do feminino. Os jovens do grupo 1 foram mantidos como controle. O grupo 2, foi submetido ao tratamento utilizando o aparelho de Fränkel, e o grupo 3 foi tratado com o Bionator de Balters. Para a comparação entre os grupos, as alterações das medidas iniciais e finais foram anualizadas buscando confiabilidade dos resultados, tornando possível à distinção dos efeitos provenientes dos aparelhos daqueles do próprio crescimento e desenvolvimento craniofacial. Os resultados demonstraram que os aparelhos referidos não promoveram alterações no desenvolvimento maxilar. No entanto, produziram um aumento na protrusão mandibular e nos comprimentos efetivo e do corpo da mandíbula, com valores maiores para o grupo tratado com o Bionator. A relação maxilomandibular melhorou significantemente nos grupos tratados em comparação ao grupo controle. A análise do padrão de crescimento craniofacial não revelou alteração significante entre os grupos; porém no grupo tratado com o Bionator, a altura facial posterior aumentou significantemente. As alterações dentoalveolares demonstraram que os incisivos superiores e inferiores inclinaram-se, respectivamente, para lingual e para vestibular nos grupos tratados. Os autores concluíram que a maioria dos efeitos aludidos pelos aparelhos estudados são dentoalveolares, contudo, ocorrem poucas, mas significantes alterações esqueléticas.

Neste mesmo ano (2002), CHEN; WILL; NIEDERMAN ${ }^{37}$ realizaram uma pesquisa com o intuito de verificar se os aparelhos ortopédicos (Bionator, Bass, Fränkel, Twin Block) para o tratamento da Classe II realmente estimulam o crescimento mandibular. Os autores avaliaram 17 artigos anteriormente publicados e selecionaram 6 pesquisas que preencheram os requisitos desejados. Foram analisadas 12 medidas cefalométricas, sendo 10 lineares e 2 angulares. Os 
resultados demonstraram que apenas as medidas Ar-Pog e Ar-Gn apresentaram diferença estatisticamente significante comparando os grupos tratados e controle. Os autores concluíram que se deve reavaliar o uso destes aparelhos com a finalidade de estimular o crescimento da mandíbula.

Em 2003, RABIE; SHE; HAGG ${ }^{127}$ objetivaram avaliar os efeitos dos aparelhos ortopédicos (avanço mandibular) no crescimento do côndilo. O estudo quantificou a presença do fator de transcrição Sox 9, regulador da diferenciação dos condrócitos, e de colágeno tipo II, em um grupo experimental e outro controle. A amostra constou de 165 ratas, que foram dividas aleatoriamente em dois grupos. Os resultados demonstraram maior quantidade de Sox 9 e do colágeno tipo II no grupo experimental. Verificaram um aumento na quantidade de osso neoformado no grupo experimental, durante o período ativo de tratamento. No entanto, após a remoção do aparelho, não se observou diferença entre os grupos, quanto à neoformação óssea. Os autores concluíram que os aparelhos ortopédicos de avanço mandibular aceleram e aumentam o crescimento condilar. Isto ocorre devido a uma maior diferenciação de células mesenquimais em condrócitos induzindo a uma maior quantidade de matriz cartilaginosa.

No mesmo ano (2003) FALTIN JUNIOR et al. ${ }^{51}$ realizaram um estudo com o objetivo de avaliar os efeitos, a longo prazo, do tratamento ortopédico/ortodôntico com o Bionator, seguido de aparelho fixo e determinar a época ideal para o início deste protocolo de tratamento. A amostra constitui de 23 pacientes com Classe II, 1a divisão tratados com o Bionator, e 21 jovens não tratados, que apresentavam a mesma má oclusão. O grupo experimental foi dividido em dois grupos de acordo com a idade esquelética avaliada pela maturidade das vértebras cervicais. Os grupos foram comparados ao grupo controle e entre si nos diferentes períodos de observação: inicial (T1), ao término da fase ortopédica (T2) e ao final do tratamento com aparelho fixo (T3). Os resultados indicaram que o tratamento com o Bionator seguido de terapia com aparelho fixo, é mais efetivo e estável quando instituído durante o pico de crescimento pubertal, comparado com um tratamento mais precoce (antes do pico). Os autores concluíram que a época ideal para o início deste 
protocolo de tratamento é determinada pela visualização da concavidade das bordas inferiores da segunda e terceira vértebras.

Recentemente (2003), ALMEIDA et al. ${ }^{7}$ avaliaram cefalometricamente as alterações esqueléticas e dentoalveoloares propiciadas pelo Bionator no tratamento da má oclusão de Classe II, 1a divisão. Utilizaram uma amostra com 44 pacientes, sendo 22 tratados e 22 jovens com má oclusão semelhante que não receberam tratamento ortodôntico. Os resultados mostraram que o Bionator não promoveu alterações no desenvolvimento maxilar. No entanto, produziu um aumento na protrusão mandibular e nos comprimentos efetivo e do corpo da mandíbula. A análise do padrão de crescimento craniofacial não revelou alteração significante entre os grupos, porém, no grupo tratado a altura facial posterior (S-Go) aumentou significantemente. Os incisivos superiores inclinaram para lingual e os inferiores para vestibular com o tratamento instituído. Os autores concluíram que a correção da má oclusão de Classe II, 1a divisão, com o Bionator, ocorre pela combinação de efeitos esqueléticos na mandíbula e também, em grande parte, por alterações dentoalveolares significantes. 
3 PROPOSIÇÃO 


\section{PROPOSIÇÃO}

Com o propósito de avaliar e comparar os efeitos de duas abordagens

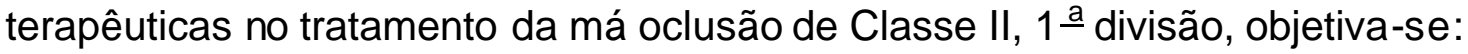

-Analisar cefalometricamente as alterações dentoesqueléticas e tegumentares de dois grupos de 30 jovens cada, com má oclusão de Classe II, 1a divisão de Angle, tratados com o Aparelho Extrabucal Conjugado (splint maxilar) e com o Bionator de Balters e comparar com um grupo de 30 jovens portadores de má oclusão semelhante que não foram submetidos ao tratamento ortodôntico.

3.1- Os principais tópicos a serem verificados entre os três grupos com relação às alterações dentoesqueléticas e tegumentares foram divididos de acordo com as seguintes áreas:

3.1.1- Componente maxilar;

3.1.2- Componente mandibular;

3.1.3- Relação maxilomandibular;

3.1.4- Relação vertical;

3.1.5- Componente dentoalveolar e,

3.1.6- Perfil tegumentar. 
4 MATERIAL E MÉTODOS 


\section{MATERIAL E MÉTODOS}

\subsection{Material}

\subsubsection{Obtenção da amostra}

A amostra constituiu-se de 180 telerradiografias em norma lateral, de 90 jovens brasileiros de ambos os gêneros provenientes do acervo da Disciplina de Ortodontia da Faculdade de Odontologia de Bauru, da Universidade de São Paulo e do arquivo do Centro Odontológico Rodrigues de Almeida - CORA (clínica particular de ortodontia do Professor Dr. Renato Rodrigues de Almeida). Os critérios para seleção da amostra basearam-se nas seguintes características:

1-Os jovens apresentavam inicialmente má oclusão de Classe II, $1^{a}$ divisão de Angle, avaliada clinicamente e por meio dos modelos de estudo;

2-Exclusão de jovens com Classe II, 1 a divisão, subdivisão;

3-Leucodermas, descendentes de italianos, portugueses e espanhóis;

4-Ausência de agenesias ou perdas de dentes permanentes.

Com a finalidade de identificar os efeitos do tratamento e compará-los às alterações cefalométricas produzidas pelo crescimento na má oclusão de Classe II, 1a divisão de Angle, a amostra foi dividida em 3 grupos:

-Grupo 1 (controle), constituído de 30 jovens, sendo 15 do gênero masculino e 15 do feminino que apresentavam má oclusão de Classe II, 1a divisão de Angle, não submetidos a nenhum tipo de tratamento ortodôntico com idade inicial média de 10,02 anos, acompanhados por um período médio de 1,49 anos. Selecionourse esta amostra a partir de um grupo de jovens que foi anualmente radiografado e controlado pela Disciplina de Ortodontia da FOB-USP com o fim de obter uma amostra longitudinal de oclusões jovens, desde a dentadura mista até a permanente.

Baseado nestes dados, e sabendo-se da real necessidade em se utilizar um grupo de jovens com más oclusões semelhantes para as devidas comparações de 
jovens tratados e não tratados, selecionourse 30 jovens agrupados de acordo com a idade e o gênero dos outros componentes dos grupos 2 e 3.

-Grupo 2, submetido ao tratamento utilizando o aparelho extrabucal conjugado, apresentando 15 jovens do gênero masculino e 15 do feminino, com idade inicial média de 10,02 anos e acompanhados por um período médio de 1,78 anos. Todos os pacientes deste grupo foram tratados no CORA - Centro Odontológico Rodrigues de Almeida.

-Grupo 3, tratado com o Bionator, constituindo-se de 15 jovens do gênero masculino e 15 do feminino, com idade inicial média de 10,35 anos e acompanhados por um período médio de 1,52 anos. Os pacientes foram tratados nos cursos de PósGraduação (mestrado e doutorado) da Faculdade de Odontologia de Bauru, Universidade de São Paulo. 


\subsubsection{Descrição dos aparelhos utilizados nos grupos experimentais}

\subsubsection{Aparelho Extrabucal Conjugado (splint maxilar)}

O AEB conjugado é composto por uma placa de acrílico superior, com plano de levantamento oclusal e com parafuso expansor, arco vestibular, grampo de Adams, arco facial e casquete com tração alta. Para a retenção da placa são construídos grampos de Adams nos molares e um arco vestibular usado para a verticalização dos incisivos, se necessário, ou para prevenir a sua vestibularização.

O arco facial é incluído no acrílico, passando por distal dos primeiros molares decíduos ou entre os pré-molares. As extremidades do arco externo são dobradas na altura dos primeiros molares superiores ou ao nível do canto externo do olho, (aproximadamente $2 \mathrm{~cm}$ após o término da placa acrílica) onde são inseridos os elásticos que promovem uma força com ponto de aplicação mais próximo ao centro de resistência da maxila, ou seja, com inclinação de 45 graus acima do plano oclusal direcionada ao centro de resistência da maxila gerando força de compressão perpendicularmente às suturas primárias maxilares (Frontomaxilar, Zigomáticomaxilar e Pterigopalatina). O acrílico que recobre a face oclusal dos dentes posteriores deve ser delgado para não promover a translação condilar ou aumento da altura facial do paciente geralmente vertical. Neste gancho, são utilizados elásticos de 1/2 polegada de diâmetro acoplados ao casquete com tração alta, permitindo uma restrição tanto do deslocamento anterior da maxila quanto da extrusão dos molares superiores, melhorando o relacionamento maxilomandibular, além de permitir a retenção do aparelho.

Manipulação clínica do aparelho:

Os pacientes utilizaram o aparelho por 16 a 18 horas diárias com força entre 350 a $500 \mathrm{~g}$ e os elásticos de tração de $1 / 2$ polegada foram trocados pelo próprio paciente a cada dez dias. Procedeu a ativação mensal do parafuso expansor com $1 / 4$ volta/mês para melhor ajuste transversal da maxila com a mandíbula. 


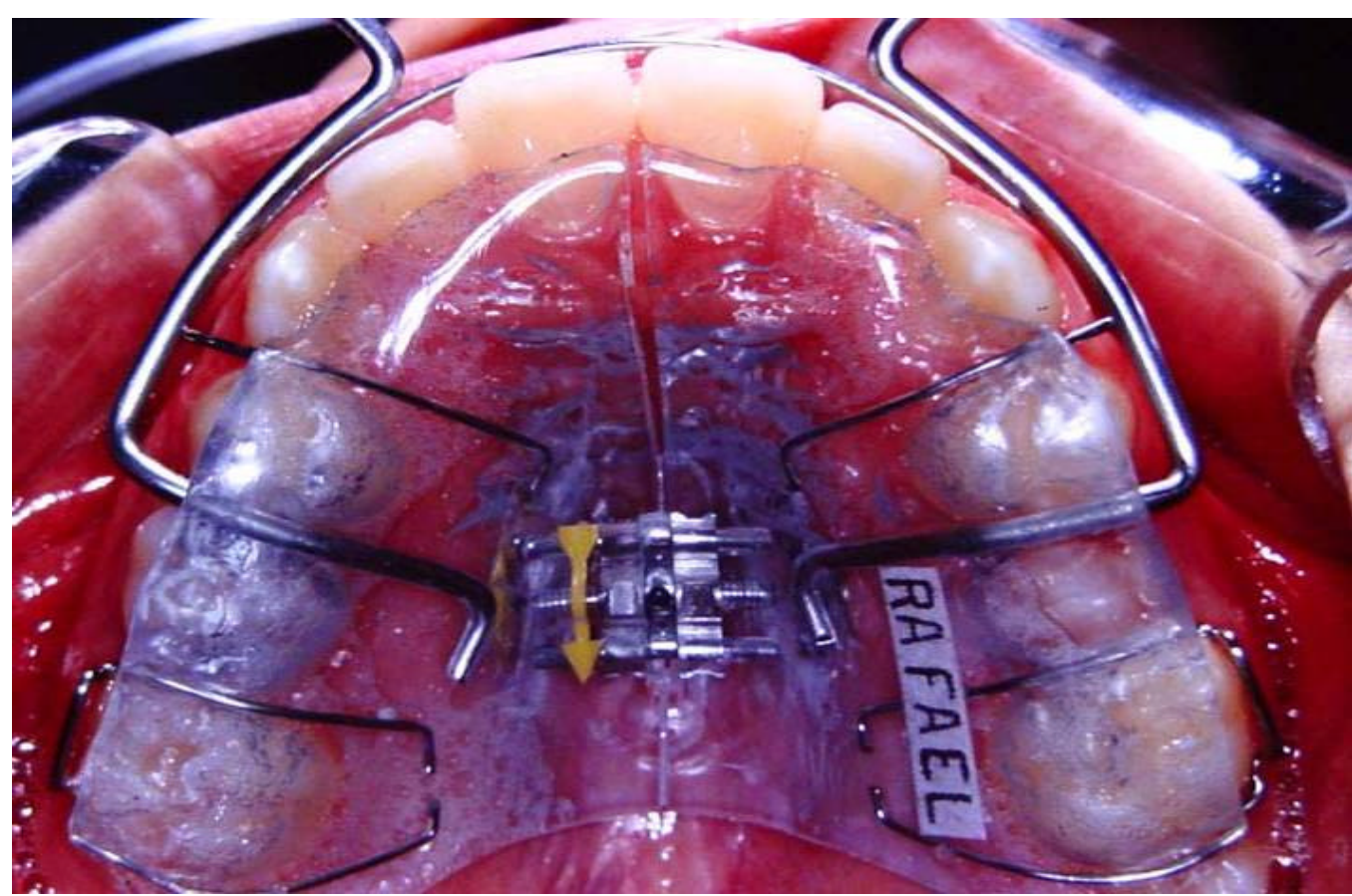

FIGURA A - AEB conjugado - vista oclusal superior.

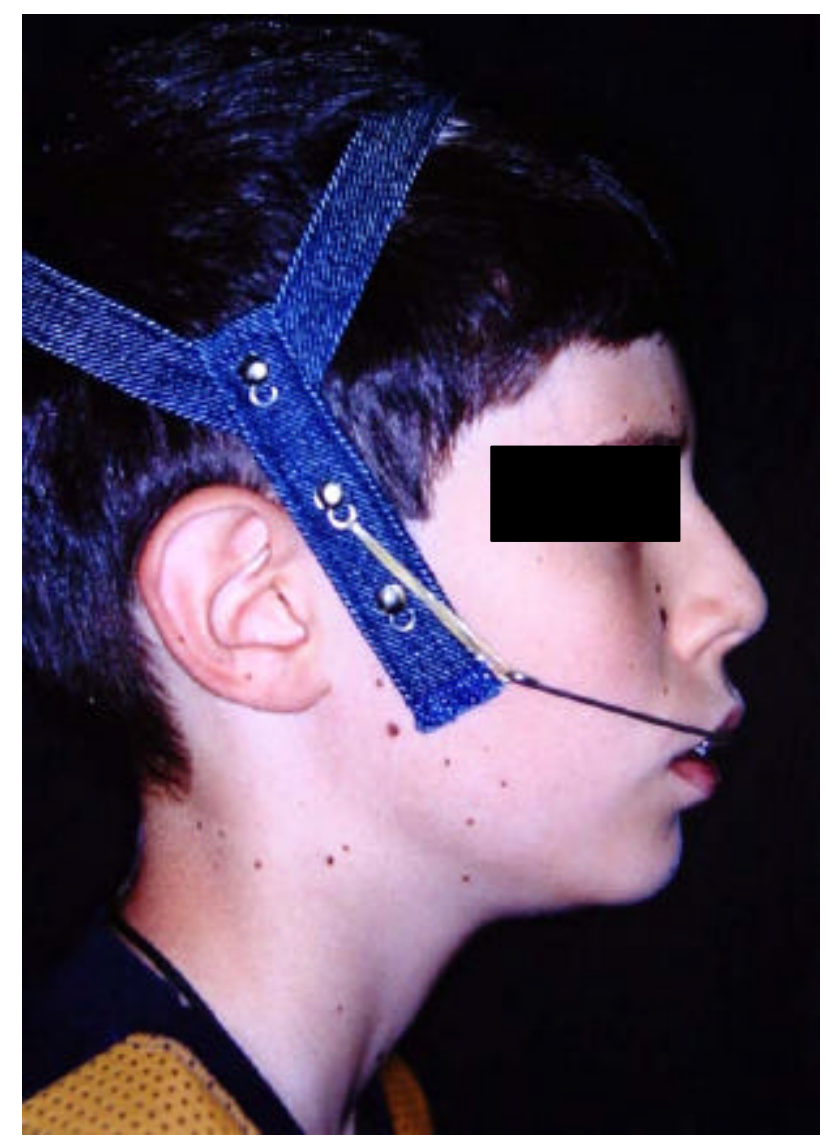

FIGURA B - Paciente com o aparelho (AEB conjugado). 


\subsubsection{Aparelho do tipo Bionator}

O aparelho utilizado (figura $C$ ) apresentou um desenho baseado no aparelho original de Balters e adaptado por ASCHER ${ }^{15}$. O Bionator apresenta, na sua constituição, quatro elementos básicos: uma base de acrílico, alças palatina e vestibular e dobras do bucinador, sendo que cada qual, dependendo do tipo de aparelho, apresenta características específicas de acordo com as diferentes finalidades terapêuticas. Algumas propriedades deste aparelho diferiram da forma original proposta por Balters. A parte ântero-inferior de acrílico recobre os incisivos inferiores, diminuindo a extrusão e protrusão dos mesmos (JANSON; NOACHTAR ${ }^{80}$ ). A alça vestibular construída originalmente para guiar ou facilitar o vedamento labial, pode tocar suavemente os incisivos superiores, funcionando como elemento ativo durante o tratamento (MARTINS ${ }^{105}$ ). Além disso, a extensão de acrílico no arco inferior projeta-se inferiormente mais que 2 a $3 \mathrm{~mm}$, como preconizado por Balters, em função de se obter um melhor efeito dentário ${ }^{105}$.

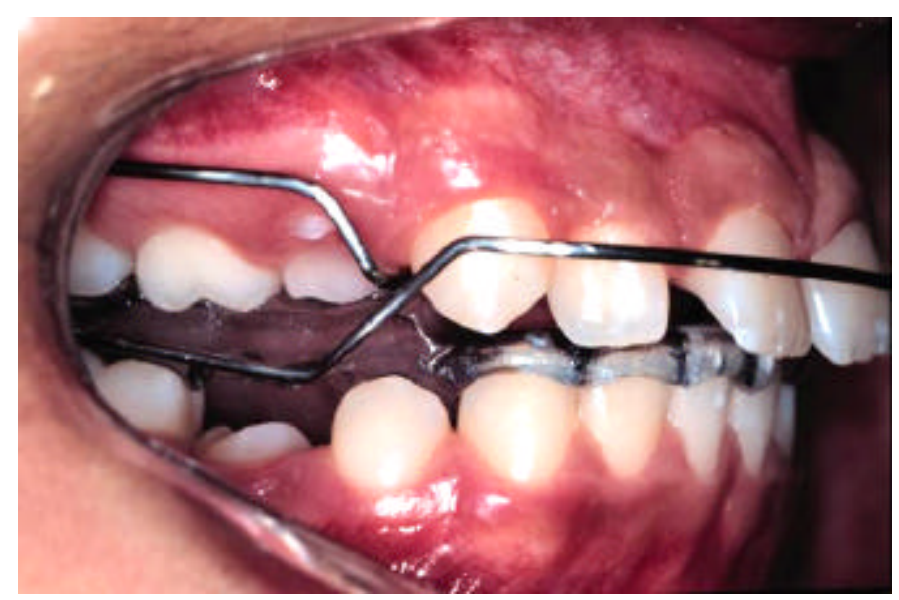

FIGURA C - Bionator de Balters modificado $\left(\mathrm{ASCHER}^{15}\right)$. 
Visando a padronização do estímulo ântero-posterior de avanço mandibular no grupo 3, executou-se a mordida construtiva utilizando um rolete de lâmina de cera $\mathrm{n}^{\circ}$ 7, objetivando a orientação nos planos horizontal, vertical e transversal ${ }^{80}$. No sentido horizontal, a mandíbula foi avançada $5 \mathrm{~mm}$ e no vertical abriu-se a mordida cerca de $5 \mathrm{~mm}$. Para os casos que apresentavam um trespasse horizontal maior que $7 \mathrm{~mm}$, realizava-se um avanço mandibular gradual, ou seja, a cada 3 meses respeitando o limite de 2 a $3 \mathrm{~mm}$ a cada avanço. No sentido transversal, manteve-se a coincidência das linhas medianas esqueléticas superior e inferior. Nos casos de desvio da linha média dentária, manteve-se o desvio durante a confecção da mordida construtiva.

\subsection{Métodos}

\subsubsection{Telerradiografias em norma lateral}

Utilizou-se duas telerradiografias, em norma lateral, de cada paciente, consideradas como T1 (inicial) e T2 (final). As radiografias foram obtidas em diferentes aparelhos, porém em todas as tomadas radiográficas respeitaram-se os critérios convencionais de padronização para as técnicas e processamentos dos filmes radiográficos, recomendados pela Disciplina de Radiologia da Faculdade de Odontologia de Bauru, da Universidade de São Paulo. Os fatores de magnificação foram determinados em 6\%,7,14\%, 9,5\% e 9,8\% para os grupos experimentais, e $6 \%$ e $9,5 \%$ para as radiografias do grupo controle.

\subsubsection{Elaboração do cefalograma}

Para a realização do cefalograma adaptou-se em cada película radiográfica uma folha de papel de acetato transparente "ULTRAPHAN", da marca UNITEK/3M de tamanho $17,5 \mathrm{~cm}$ de largura por $17,5 \mathrm{~cm}$ de comprimento e espessura de $0,07 \mathrm{~mm}$. Os cefalogramas foram traçados manualmente sobre o negatoscópio, pelo pesquisador e conferido pelo orientador da investigação, em uma sala obscurecida, emoldurado com cartolina preta, expondo-se as áreas correspondentes ao desenho 
anatômico, que foi realizado com uma lapiseira com grafite de 0,5mm. Ressalta-se que nas estruturas bilaterais (pares) que se apresentavam como imagens duplas determinou-se a média dos desenhos do lado direito e esquerdo possibilitando maior precisão na localização dos pontos cefalométricos (BAUMRIND; FRANTZ ${ }^{21}$ ). Quanto a localização dos dentes (molares e incisivos) respeitou-se os mais mesialmente posicionados (molares) e mais anteriormente posicionados para os incisivos.

Por meio de uma mesa digitalizadora Houston Instruments DT-11*, acoplada a um microcomputador 586 Pentium, transferiu-se a localização dos pontos dos cefalogramas para o programa de cefalometria Dentofacial Planner $7.0^{* *}$ onde foram processadas as mensurações envolvendo os planos e as linhas. No programa Dentofacial Planner obteve-se a correção da magnificação da imagem radiográfica, uma vez que as radiografias foram obtidas em diferentes aparelhos.

\footnotetext{
* Houston Instruments - Austin, Texas, USA.

**Dentofacial Planner Software Inc., Toronto, Ontario, Canada.
} 


\subsubsection{Delimitação das estruturas dentoesqueléticas e do perfil tegumentar (Figura 1).}

No cefalograma foram determinadas as seguintes estruturas anatômicas:

- contorno do perfil tegumentar;

- perfil do osso frontal e dos ossos nasais;

- contorno da sela túrcica;

- contorno do meato acústico externo;

- limite inferior da cavidade orbitária;

- maxila, partindo da espinha nasal posterior estendendo-se pelo assoalho da fossa nasal limitando-se anteriormente na espinha nasal anterior, e incluindo o perfil alveolar anterior e o palato duro;

- mandíbula: contorno da cortical externa da sínfise, borda inferior do corpo, borda posterior do ramo ascendente e o côndilo mandibular;

- fossa pterigomaxilar;

- "clivus" do osso occipital;

- incisivos centrais permanentes superiores e inferiores,

- primeiros molares permanentes superiores e inferiores. 


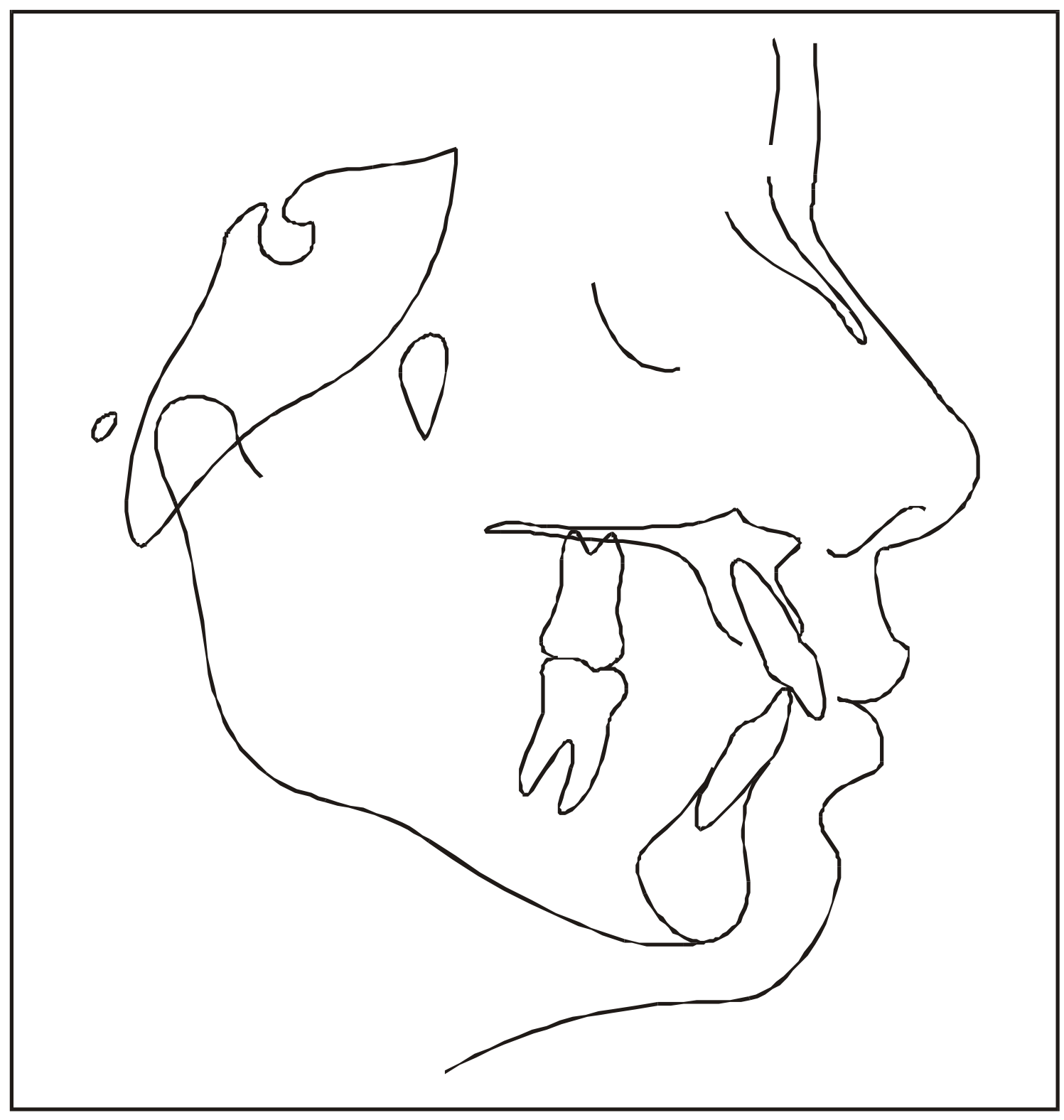

FIGURA 1 - Desenho anatômico das estruturas dentoesqueléticas e do perfil tegumentar 


\subsubsection{Demarcação dos pontos cefalométricos de referência (Figura 2).}

Empregou-se os pontos de acordo com KROGMAN; SASSOUNI ${ }^{93}$, MARTINS et al. ${ }^{104}$, McNAMARA JÚNIOR ${ }^{108}$, RICKETTS et al. ${ }^{130}$ e SCHEIDEMAN et al. ${ }^{143}$.

-S (sela túrcica) centro da concavidade óssea da sela túrcica;

-N (násio) interseção da sutura internasal com a sutura frontonasal;

-Po (pório) ponto mais superior do meato auditivo externo;

-Or (orbitário) ponto mais inferior da margem infraorbitária;

-A (subespinhal) ponto mais profundo na concavidade do contorno anterior da maxila;

-B (supramentoniano) ponto mais profundo da concavidade anterior da mandíbula;

-Pog (pogônio) ponto mais proeminente (anterior) do mento ósseo;

-Me (mentoniano) ponto mais inferior do contorno da sínfise mentoniana;

-Go (gônio) ponto médio entre os pontos mais inferior e posterior do ângulo da mandíbula, determinado geometricamente pela intersecção da bissetriz do ângulo formado pela base da mandíbula e pelo ramo mandibular;

-Gn (gnátio) ponto mais ântero-inferior do contorno do mento ósseo, determinado geometricamente pela intersecção da bissetriz do ângulo formado pelo plano mandibular (Go-Me) e pela linha facial (N-Pog), com a sínfise mentoniana;

-Co (condílio) ponto mais póstero-superior dos côndilos mandibulares; 
-ENA (espinha nasal anterior) ponto mais anterior do palato duro; interseção da parte ântero-superior da maxila com o assoalho da fossa nasal;

-ENP (espinha nasal posterior) ponto mais posterior do palato duro;

-Ls (lábio superior) ponto mais anterior do vermelhão do lábio superior;

-Li (lábio inferior) ponto mais anterior do vermelhão do lábio inferior;

-Prn (pronasal) ponto mais anterior da extremidade nasal;

-Sn (subnasal) ponto de confluência entre a margem inferior da columela do nariz e o lábio superior;

-Prn' (columela ou derivado do pronasal) ponto mais proeminente, na margem inferior da columela do nariz, localizado entre o pronasal e o subnasal,

-Pog' (pogônio tegumentar) ponto mais anterior do mento no perfil tegumentar;

-BIS (borda do incisivo superior-1) ponto mais inferior da borda incisal do incisivo central superior;

-AIS (ápice do incisivo superior-1) ponto mais superior da raiz do incisivo central superior;

-Bll (borda do incisivo inferior- $\overline{1}$ ) ponto mais superior da borda incisal do incisivo central inferior;

-All (ápice do incisivo inferior-1̄) ponto mais inferior da raiz do incisivo central inferior; 
-CMPMS (cúspide mésio-vestibular do primeiro molar superior-ㅌ) ponto mais inferior da cúspide mésio-vestibular do primeiro molar superior,

-CMPMI (cúspide mésio-vestibular do primeiro molar inferior- $\overline{6}$ ) ponto mais superior da cúspide mésio-vestibular do primeiro molar inferior. 


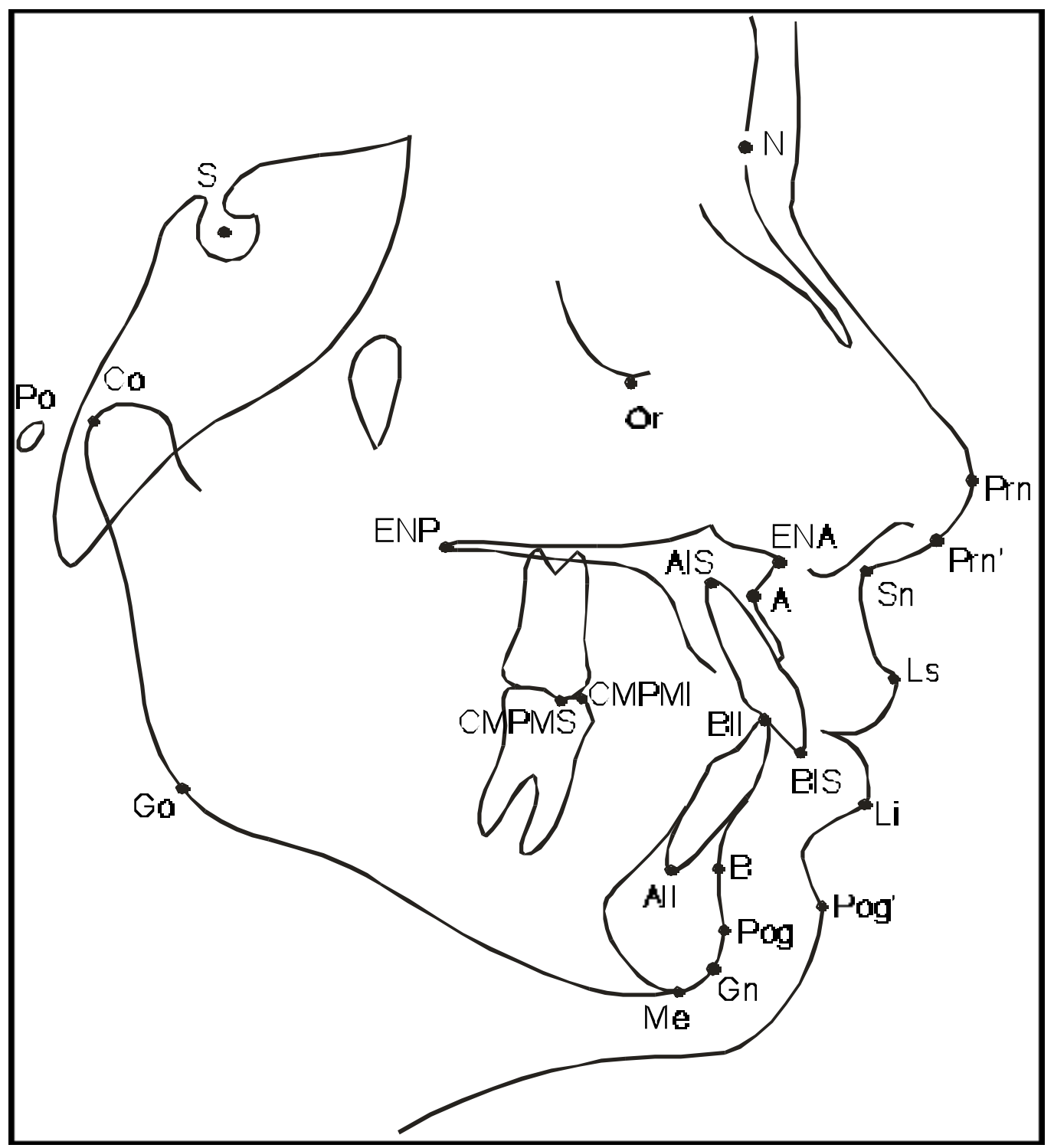

FIGURA 2 - Pontos cefalométricos utilizados 


\subsubsection{Planos e Linhas de referência (Figura 3).}

\subsection{Horizontais}

a) - Plano horizontal de Frankfurt modificado (FH), adotado por BAUMRIND; MILLER; MOLTHEN ${ }^{22}$, KALRA; BURSTONE; NANDA ${ }^{84}$ e BUSCHANG; MARTINS ${ }^{31}$ : constituído por uma linha que forma com a linha SN um ângulo de $7^{\circ}$ para baixo, passando pelo ponto $S$;

b) - Plano de Frankfurt (Po-Or): formado pelos pontos Po e Or;

c) - Plano mandibular (GoMe): formado pelos pontos Go e Me;

d) - Plano mandibular (GoGn): formado pelos pontos Go e Gn;

e) - Plano palatino (PP): formado pelos pontos ENA e ENP;

f) - Linha SN: linha que passa pelos pontos S e N;

\subsubsection{2-Verticais}

g) - Linha N perp: linha perpendicular ao plano de Frankfurt (Po-Or) passando pelo ponto $\mathrm{N}$

h) - Linha NA: linha que passa pelos pontos $\mathrm{N}$ e $\mathrm{A}$;

i) - Linha NB: linha que passa pelos pontos $\mathrm{N}$ e B;

j) - Linha AP: linha que passa pelos pontos A e P;

k) - Linha ENA-Me (AFAI): linha que passa pelos pontos ENA e Me; 
I) - Linha S-Go: linha que passa pelos pontos S e Go;

m) - Linha S-FHp: perpendicular ao plano horizontal de Frankfurt modificado (FH), partindo do ponto S;

n) - Linha Pog'-Sn (BURSTONE ${ }^{30}$ e FREITAS ${ }^{58}$ ): linha que passa pelos pontos Pog' e Sn;

o) - Longo eixo do incisivo superior: linha que passa pelos pontos BIS e AIS.

p) - Longo eixo do incisivo inferior: linha que passa pelos pontos Bll e All; 


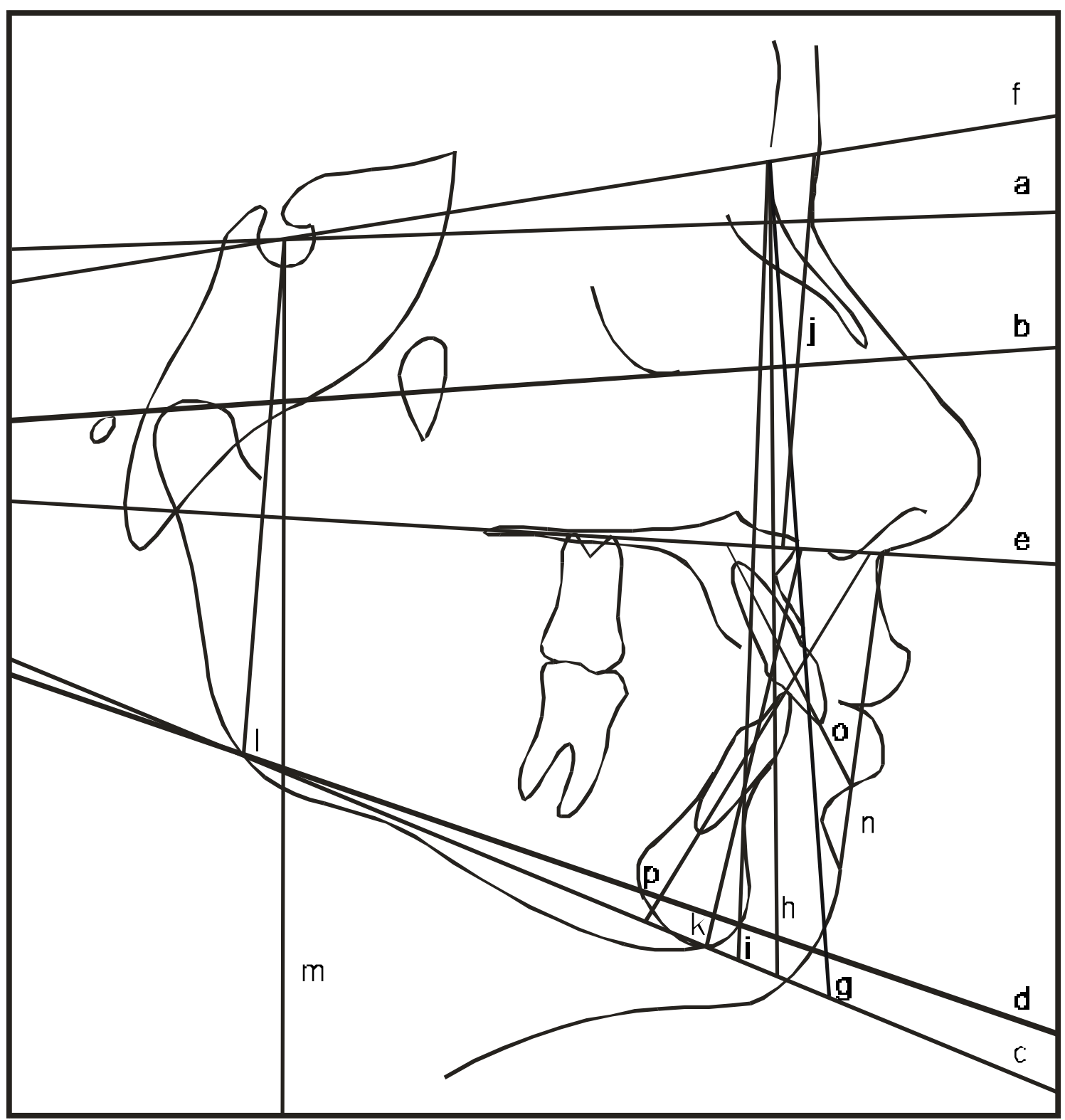

FIGURA 3 - Planos e linhas de referência 


\subsubsection{Mensuração das grandezas angulares e lineares:}

\subsection{Grandezas angulares (Figura 4).}

\subsection{Esqueléticas e tegumentares}

1) - SN.PP: ângulo formado entre a linha SN e o plano palatino (PP);

2) - SN.GoGn: ângulo formado entre a linha SN e o plano mandibular (GoGn);

3) - SNA: ângulo formado pelas linhas SN e NA;

4) - SNB: ângulo formado pelas linhas SN e NB;

5) - ANB: diferença entre os ângulos SNA e SNB;

6) - NAP: ângulo formado pelas linhas NA e AP;

7) - ANL: ângulo formado por duas semi-retas que passam pelos pontos derivados do pronasal (Prn') e lábio superior (Ls), respectivamente, apresentando como ponto comum o subnasal (Sn);

\subsection{Dentárias}

8) - IMPA: ângulo formado pelo longo eixo do incisivo inferior com o plano mandibular (GoMe);

9) - 1.NA: ângulo formado pelo longo eixo do incisivo superior com a linha NA,

10) -ī.NB: ângulo formado pelo longo eixo do incisivo inferior com a linha NB. 


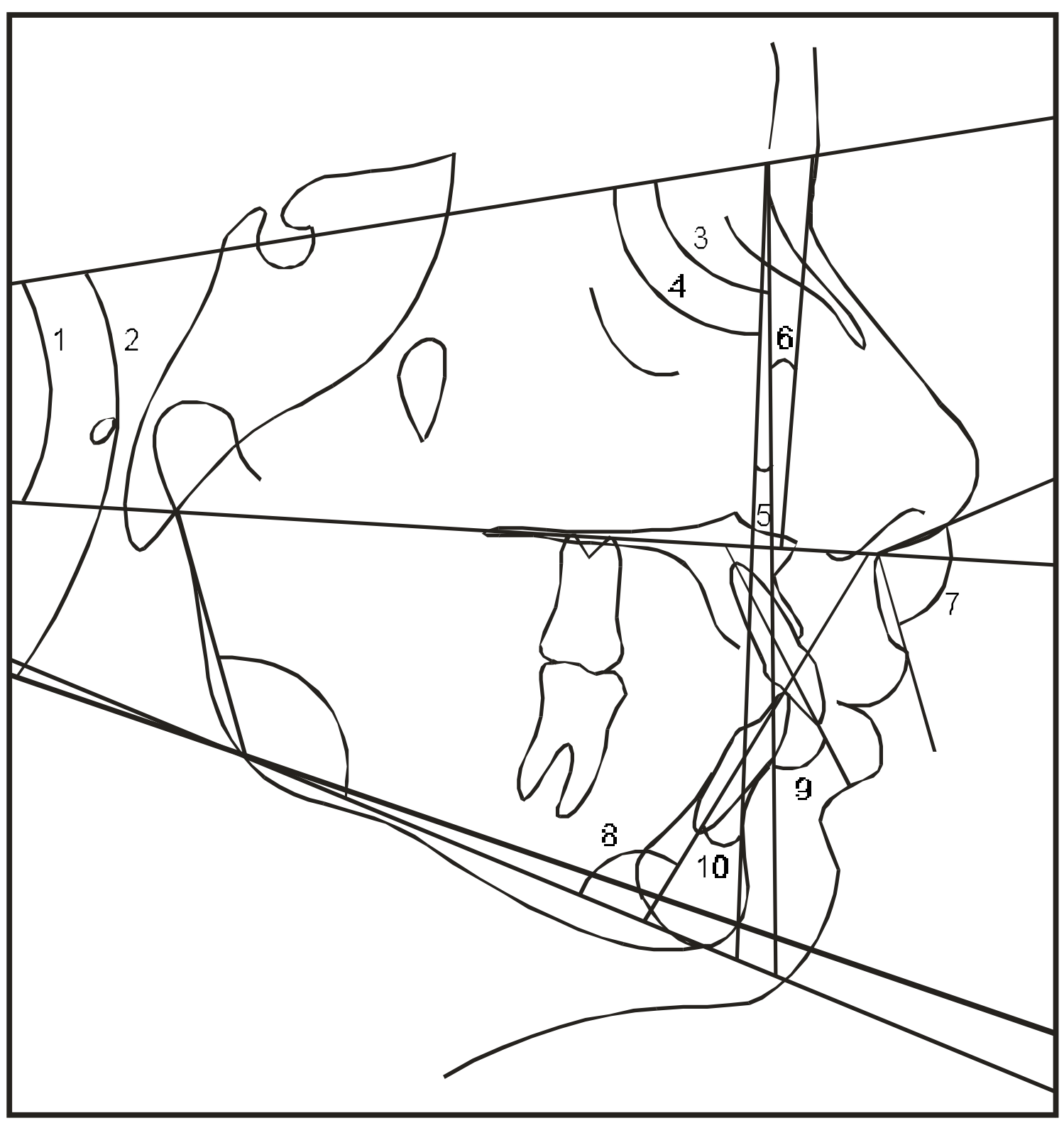

FIGURA 4 - Grandezas angulares 


\subsection{Grandezas lineares esuqléticas e tegumentares (Figuras 5 e 6)}

\subsection{Esqueléticas (Figura 5).}

11) - Go-Gn: distância do ponto Go ao Gn;

12) - Co-A: distância do ponto Co ao ponto A;

13) - Co-Gn: distância do ponto Co ao Gn;

14) - AFAl: distância entre os pontos ENA e Me;

15) - S-Go: distância entre os pontos S e Go;

16) - Nperp-A: distância do ponto A à linha Nperp;

17) - Nperp-P: distância do ponto P à linha Nperp; 


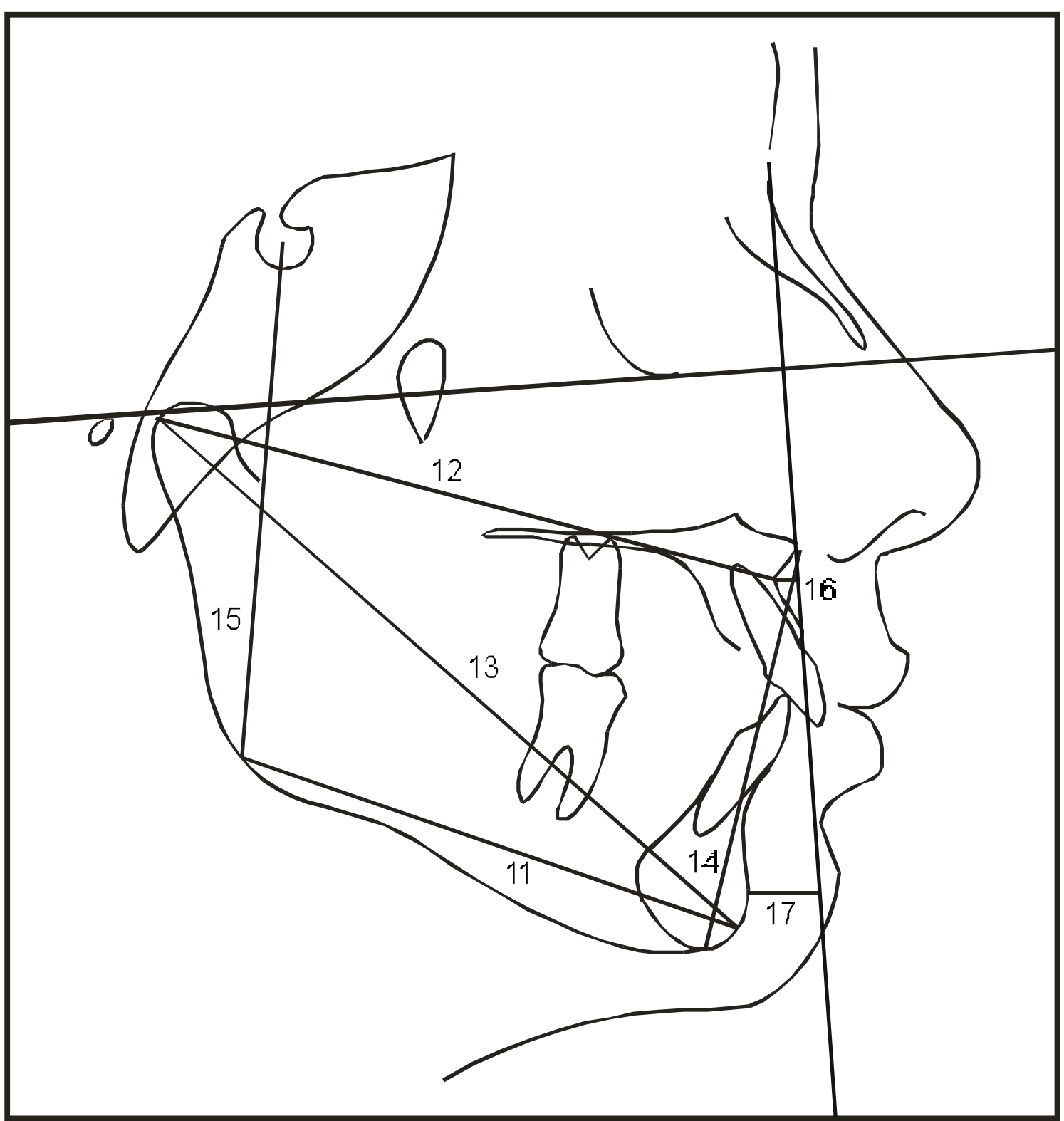

FIGURA 5- Grandezas lineares esqueléticas 


\subsection{Dentárias e tegumentares (Figura 6).}

18) - 1-NA: maior distância da face vestibular dos incisivos centrais superiores que ultrapassa a linha NA;

19) - 1-NB: maior distância da face vestibular dos incisivos centrais inferiores que ultrapassa a linha NB;

20) - 6-PP: distância entre a cúspide mésio-vestibular do primeiro molar superior permanente e o plano palatino (PP);

21) - 6-FHp: distância entre a cúspide mésio-vestibular do primeiro molar superior permanente à linha S-FHp;

22) - $\overline{6}$-GoMe: distância entre a cúspide mésio-vestibular do primeiro molar inferior permanente ao plano mandibular (GoMe);

23) - $\overline{6}$-FHp: distância entre a cúspide mésio-vestibular do primeiro molar inferior permanente à linha S-FHp;

24) - Ls-Pog'Sn: distância entre o ponto Ls e a linha Pog'-Sn;

25) - Li-Pog'Sn: distância entre o ponto Li e a linha Pog'-Sn; 


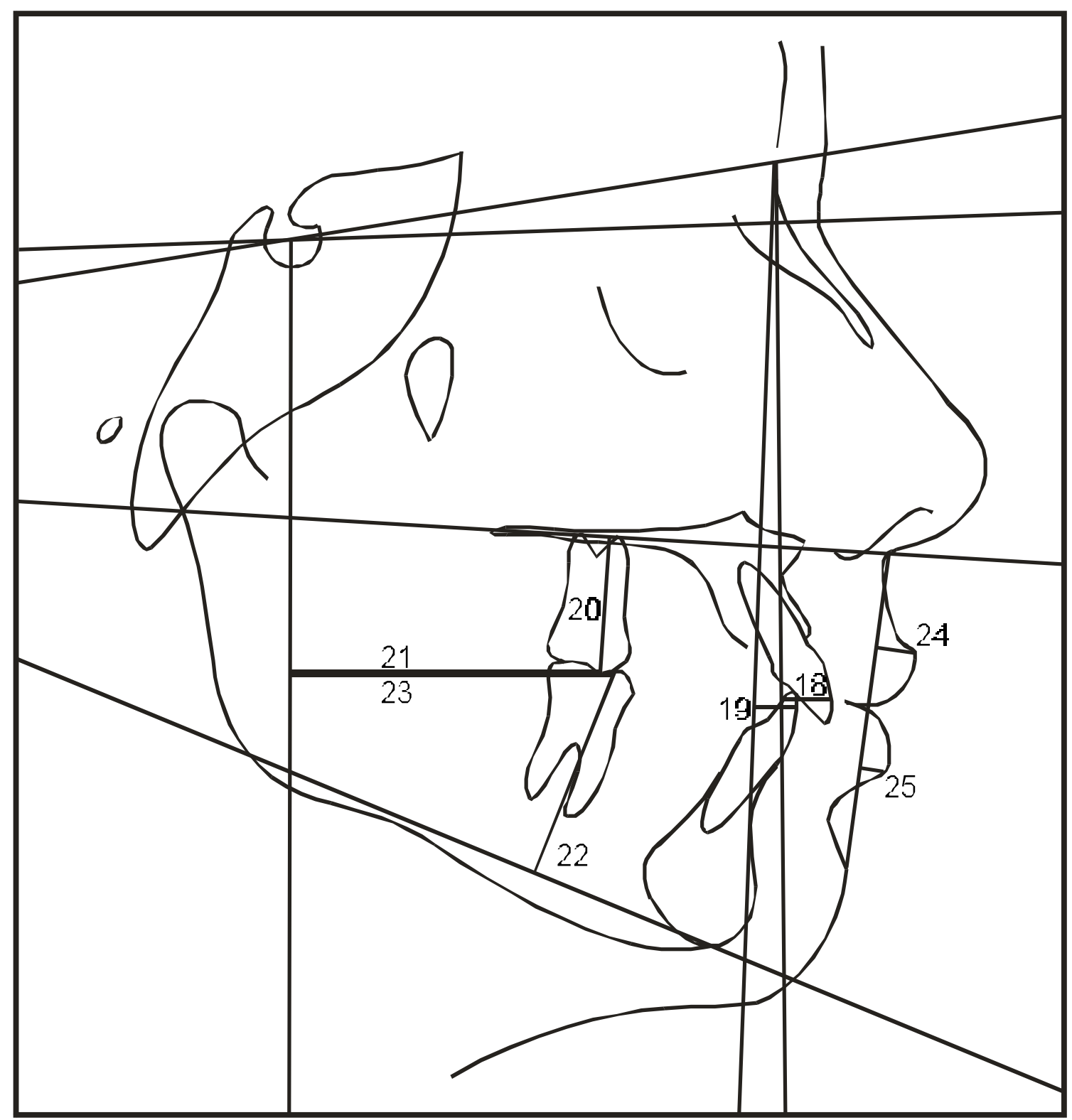

FIGURA 6- Grandezas lineares dentárias e tegumentares 


\subsection{Agrupamento das grandezas cefalométricas utilizadas na} avaliação dos distintos componentes:

a) - Componente maxilar: SNA, Nperp-A e Co-A;

b) - Componente mandibular: SNB, Nperp-P, Go-Gn e Co-Gn;

c) - Relação maxilomandibular: ANB e NAP;

d) - Relação vertical: SN.GoGn, SN.PP, AFAl e S-Go;

e) - Componente dentoalveolar: 1.NA, 1-NA, $\underline{6}-\mathrm{PP}, \underline{6}-\mathrm{FHp}$, IMPA, $1 . \mathrm{NB}, \overline{1}-\mathrm{NB}$, $\overline{6}$-GoMe e $\overline{6}$-FHp;

f) - Perfil tegumentar: ANL, Ls-Pog'Sn e Li-Pog'Sn. 


\subsection{Análise estatística}

Todas as análises estatísticas foram desenvolvidas pelo programa computadorizado Statistica*.

\subsubsection{ERRO DO MÉTODO}

Com o intuito de determinar a confiabilidade dos resultados da pesquisa, foram selecionadas ao acaso 20 telerradiografias provenientes dos 3 grupos estudados. Este número de 20 radiografias, concorda com aquele utilizado por BAUMRIND; FRANTZ21 ${ }^{21}$ Todas as radiografias foram traçadas e digitalizadas novamente pelo mesmo pesquisador após um período de 1 mês, do traçado inicial, segundo MIDTGARD; BJÖRK; LINDER-ARONSON ${ }^{110}$. Determinourse a diferença entre a primeira e a segunda mensuração de cada telerradiografia, e aplicou-se a fórmula de DAHLBERG ${ }^{42}$ para visualização do erro casual, segundo HOUSTON ${ }^{74}$.

$$
E=\sqrt{ } \Sigma d^{2} / 2 n
$$

O erro sistemático foi detectado comparando as medições por meio do teste "t” pareado, utilizando um programa estatístico*.

\subsection{2 - EQUIVALÊNCIA ENTRE AS IDADES DOS GRUPOS}

As médias de idades dos pacientes no início e no final do tratamento, bem como a duração desse período, foram avaliadas por meio da análise de Variância ANOVA para verificar o grau de semelhança entre os grupos. A equivalência, principalmente, do período de avaliação dos grupos tratados e controle é importante, uma vez que propicia resultados mais confiáveis quando se compara os efeitos provenientes dos aparelhos com os efeitos do próprio crescimento e desenvolvimento craniofacial.

\footnotetext{
* Statistica $6.0^{t m}$, Statistical Software for Windows Version 6.0.
} 


\subsection{3- COMPARAÇÃO ENTRE OS GRUPOS}

Inicialmente realizourse uma análise intergrupos das médias iniciais das grandezas cefalométricas de cada grupo, utilizando a análise de Variância (ANOVA), com o objetivo de verificar o grau de similaridade entre os grupos.

As diferenças entre as mensurações nas fases pré e pós-tratamento determinaram as alterações reais. Para verificação das alterações ocorridas nos três grupos foram calculadas as diferenças entre as medidas inicial e final, utilizando a fórmula:

\section{VALOR FINAL - VALOR INICIAL= DIFERENÇA}

Os dados obtidos nas medidas cefalométricas (diferenças das médias das alterações) para os três grupos foram computados pela análise de variância (ANOVA) para a verificação da hipótese nula de que os efeitos do crescimento no grupo 1 , ou do tratamento nos grupos 2 e 3 são iguais. Quando verificadas diferenças estatísticas entre os grupos, os valores das alterações das médias foram submetidos ao teste estatístico de Tukey, com a finalidade de identificar quais foram responsáveis pela rejeição da hipótese nula, de igualdade entre os grupos. Em todas as análises empregadas foram considerados estatisticamente significantes os resultados com valor de $p \leq 0,05$ e $p \leq 0,01$. 
5 RESULTADOS 


\section{RESULTADOS}

Os resultados mostram o tratamento estatístico dos dados, elucidados em forma de tabelas. Iniciou-se verificando o erro do método cefalométrico por meio do teste "t" e da fórmula de Dahlberg. Na seqüência, realizourse a comparação intergrupos dos resultados pela análise de variância (ANOVA) que foi complementada pelo teste de Tukey. Os dados foram divididos em tabelas de acordo com a análise estatística empregada.

\section{1 - FAIXA ETÁRIA DOS PACIENTES (Tabela 1)}

As médias de idades médias dos pacientes no início e no final do tratamento, bem como a duração desse período, foram dispostas na tabela 1 de acordo com cada grupo.

GRUPO 1- 30 jovens mantidos como controle.

GRUPO 2- 30 jovens tratados com o aparelho extrabucal (AEB) conjugado.

GRUPO 3- 30 jovens tratados com o Bionator de Balters.

Os valores individuais de cada paciente encontram-se nos apêndices 1, 2 e 3.

Os resultados da comparação entre as médias de idade e dos tempos de avaliação nos três grupos encontram-se dispostos na tabela 2.

Os pacientes dos grupos estudados apresentaram uma compatibilidade das idades médias iniciais e finais e foram avaliados por um período semelhante de acompanhamento, como pode ser observado na tabela 2. 
TABELA 1 - Média das idades iniciais e finais dos jovens nos 3 grupos e o tempo médio de avaliação.

\begin{tabular}{c|c|c|c}
\hline GRUPOS & $\begin{array}{c}\text { MÉDIA DE IDADE } \\
\text { INICIAL }\end{array}$ & $\begin{array}{c}\text { MÉDIA DE IDADE } \\
\text { FINAL }\end{array}$ & $\begin{array}{c}\text { TEMPO MÉDIO DE } \\
\text { AVALIAÇÃO }\end{array}$ \\
\hline $\mathbf{1}$ (controle) & $10,02 \mathrm{a}$. & $11,51 \mathrm{a}$. & $1,49 \mathrm{a}$. \\
\hline $\mathbf{2}$ (AEB conjugado) & $10,02 \mathrm{a}$. & $11,80 \mathrm{a}$. & $1,78 \mathrm{a}$. \\
\hline $\mathbf{3}$ (Bionator) & $10,35 \mathrm{a}$. & $11,87 \mathrm{a}$. & $1,52 \mathrm{a}$. \\
\hline
\end{tabular}

TABELA 2 - Análise de Variância (ANOVA) entre as médias das idades iniciais e finais dos jovens nos 3 grupos e do tempo médio de avaliação.

\begin{tabular}{c|ccc|cc|c}
\hline \multirow{2}{*}{ VARIÁVEIS } & \multicolumn{3}{|c|}{ VALORES MÉDIOS } & \multicolumn{2}{c|}{$\begin{array}{c}\text { ANALISE DE } \\
\text { VARIÂNCIA }\end{array}$} & \multirow{2}{*}{ SIG. } \\
\cline { 2 - 4 } & GRUPO1 & GRUPO 2 & GRUPO 3 & F & P & \\
\hline IDADE INICIAL & $10,02 a$. & $10,02 a$ & $10,35 a$. & 1,09 & 0,34 & N/S \\
\hline IDADE FINAL & $11,51 a$. & $11,80 a$. & $11,87 a$. & 0,98 & 0,37 & N/S \\
\hline $\begin{array}{c}\text { TEMPO DE } \\
\text { AVALIAÇÃO }\end{array}$ & $1,49 a$. & $1,78 a$. & $1,52 a$. & 2,21 & 0,11 & N/S \\
\hline
\end{tabular}

\section{2 - ERRO DO MÉTODO (Tabela 3)}

Os valores das grandezas cefalométricas avaliadas encontram-se nos apêndices de 25 a 31 . A tabela 3 apresenta os resultados do erro do método cefalométrico. 
TABELA 3 - Cálculo do erro do método intra-examinador. Diferença entre a primeira e a segunda mensuração (milímetros ou graus), desvio-padrão das medidas, erro casual (Dahlberg) e erro sistemático (teste "t").

\begin{tabular}{|c|c|c|c|c|c|}
\hline $\begin{array}{l}\text { GRANDEZAS } \\
\text { CEFALOMÉTRICAS }\end{array}$ & $\begin{array}{l}\text { DIFERENÇA } \\
\text { (milimetros } \\
\text { ou graus) }\end{array}$ & $\begin{array}{l}\text { DESVIO-PADRÃO } \\
\text { (D.P.) }\end{array}$ & $\begin{array}{l}\text { ERRO CASUAL } \\
\text { (Dahlberg) }\end{array}$ & $\begin{array}{l}\text { ERRO SISTEMÁTICO } \\
\text { (“p”) }\end{array}$ & SIG. \\
\hline \multicolumn{6}{|l|}{ Maxilares } \\
\hline SNA & $-0,11$ & 0,59 & 0,42 & 0,400 & $\mathrm{~N} / \mathrm{S}$ \\
\hline Co-A & $-0,11$ & 0,59 & 0,41 & 0,398 & $\mathrm{~N} / \mathrm{S}$ \\
\hline Nperp-A & 0,05 & 0,56 & 0,39 & 0,697 & $\mathrm{~N} / \mathrm{S}$ \\
\hline \multicolumn{6}{|l|}{ Mandibulares } \\
\hline SNB & 0,01 & 0,49 & 0,34 & 0,890 & $\mathrm{~N} / \mathrm{S}$ \\
\hline Co-Gn & 0,24 & 0,67 & 0,49 & 0,130 & $\mathrm{~N} / \mathrm{S}$ \\
\hline Go-Gn & 0,07 & 0,51 & 0,35 & 0,520 & $\mathrm{~N} / \mathrm{S}$ \\
\hline Nperp-P & $-0,10$ & 0,79 & 0,55 & 0,563 & $\mathrm{~N} / \mathrm{S}$ \\
\hline \multicolumn{6}{|l|}{ Maxilomandibular } \\
\hline ANB & 0,07 & 0,39 & 0,27 & 0,434 & $\mathrm{~N} / \mathrm{S}$ \\
\hline NAP & 0,09 & 0,91 & 0,63 & 0,648 & $\mathrm{~N} / \mathrm{S}$ \\
\hline \multicolumn{6}{|l|}{ Verticais } \\
\hline SN.GoGn & $-0,12$ & 0,90 & 0,62 & 0,558 & $\mathrm{~N} / \mathrm{S}$ \\
\hline SN.PP & $-0,34$ & 1,14 & 0,82 & 0,195 & $\mathrm{~N} / \mathrm{S}$ \\
\hline S-GO & 0,18 & 0,32 & 0,25 & 0,191 & $\mathrm{~N} / \mathrm{S}$ \\
\hline AFAl & 0,16 & 0,84 & 0,59 & 0,394 & $\mathrm{~N} / \mathrm{S}$ \\
\hline \multicolumn{6}{|c|}{ Dentárias superiores } \\
\hline 1.NA & 0,14 & 1,11 & 0,77 & 0,567 & $\mathrm{~N} / \mathrm{S}$ \\
\hline $1-N A$ & $-0,01$ & 0,42 & 0,29 & 0,917 & $\mathrm{~N} / \mathrm{S}$ \\
\hline$\underline{6}-\mathrm{FHp}$ & $-0,54$ & 1,37 & 1,00 & 0,097 & $\mathrm{~N} / \mathrm{S}$ \\
\hline$\underline{6}-P P$ & $-0,17$ & 0,45 & 0,33 & 0,111 & $\mathrm{~N} / \mathrm{S}$ \\
\hline \multicolumn{6}{|l|}{ Dentárias inferiores } \\
\hline$\overline{1 . N B}$ & $-0,09$ & 0,84 & 0,58 & 0,638 & $\mathrm{~N} / \mathrm{S}$ \\
\hline$\overline{1-N B}$ & 0,04 & 0,25 & 0,17 & 0,493 & $\mathrm{~N} / \mathrm{S}$ \\
\hline$\overline{6-F H p}$ & 0,48 & 1,17 & 0,87 & 0,079 & $\mathrm{~N} / \mathrm{S}$ \\
\hline IMPA & 0,03 & 1,23 & 0,84 & 0,900 & $\mathrm{~N} / \mathrm{S}$ \\
\hline 6-GoMe & 0,20 & 0,38 & 0,30 & 0,029 & SIG* \\
\hline \multicolumn{6}{|l|}{ Tegumentares } \\
\hline ANL & 0,01 & 5,71 & 0,93 & 0,990 & $\mathrm{~N} / \mathrm{S}$ \\
\hline Ls-Pog'Sn & 0,01 & 0,54 & 0,37 & 0,935 & $\mathrm{~N} / \mathrm{S}$ \\
\hline Li-Pog'Sn & 0,09 & 0,41 & 0,29 & 0,315 & $\mathrm{~N} / \mathrm{S}$ \\
\hline
\end{tabular}




\section{3 - COMPARAÇÃO INTERGRUPOS DAS MEDIDAS INICIAIS PELA ANÁLISE} DE VARIÂNCIA - ANOVA (Tabela 4).

$\mathrm{Na}$ tabela 4, observa-se o resultado da análise de variância (ANOVA) na comparação intergrupos, na fase pré-tratamento, para determinar o grau de similaridade entre os três grupos estudados, quanto aos seus valores cefalométricos iniciais. 
TABELA 4 - Análise de Variância (ANOVA) entre os 3 grupos dos valores médios das medidas iniciais.

\begin{tabular}{|c|c|c|c|c|c|c|}
\hline \multirow{2}{*}{$\begin{array}{l}\text { GRANDEZAS } \\
\text { CEFALOMÉTRICAS }\end{array}$} & \multicolumn{3}{|c|}{ MÉDIAS DAS MEDIDAS INICIAIS } & \multicolumn{2}{|c|}{ ANÁLISE DE VARIÂNCIA } & \multirow{2}{*}{ SIG. } \\
\hline & GRUPO 1 & GRUPO 2 & GRUPO 3 & $\mathbf{F}$ & $\mathbf{P}$ & \\
\hline \multicolumn{7}{|l|}{ Maxilares } \\
\hline SNA & 80,44 & 81,37 & 81,45 & 0,85 & 0,428 & $\mathrm{~N} / \mathrm{S}$ \\
\hline Nperp-A & $-2,21$ & $-1,47$ & $-1,43$ & 0,64 & 0,526 & $\mathrm{~N} / \mathrm{S}$ \\
\hline Co-A & 81,02 & 78,83 & 82,28 & 6,94 & 0,001 & Sig.** \\
\hline \multicolumn{7}{|l|}{ Mandibulares } \\
\hline SNB & 75,36 & 75,19 & 75,48 & 0,06 & 0,937 & $\mathrm{~N} / \mathrm{S}$ \\
\hline Nperp-P & $-10,68$ & $-11,23$ & $-11,05$ & 0,06 & 0,932 & $\mathrm{~N} / \mathrm{S}$ \\
\hline Go-Gn & 65,56 & 64,49 & 66,73 & 1,70 & 0,187 & $\mathrm{~N} / \mathrm{S}$ \\
\hline Co-Gn & 99,25 & 96,96 & 100,31 & 4,84 & 0,010 & Sig** \\
\hline \multicolumn{7}{|l|}{ Maxilomandibular } \\
\hline ANB & 5,07 & 6,18 & 5,96 & 3,17 & 0,056 & $\mathrm{~N} / \mathrm{S}$ \\
\hline NAP & 8,63 & 10,84 & 10,54 & 2,42 & 0,094 & $\mathrm{~N} / \mathrm{S}$ \\
\hline \multicolumn{7}{|l|}{ Verticais } \\
\hline SN.GoGn & 32,36 & 34,48 & 33,25 & 1,39 & 0,252 & $\mathrm{~N} / \mathrm{S}$ \\
\hline SN.PP & 7,67 & 7,62 & 7,61 & 0,00 & 0,996 & $\mathrm{~N} / \mathrm{S}$ \\
\hline AFAI & 58,76 & 58,77 & 59,88 & 0,73 & 0,483 & $\mathrm{~N} / \mathrm{S}$ \\
\hline S-Go & 64,19 & 61,15 & 64,73 & 7,37 & 0,001 & Sig $^{* *}$ \\
\hline \multicolumn{7}{|l|}{ Dentárias superiores } \\
\hline 1.NA & 24,89 & 27,89 & 26,22 & 1,74 & 0,180 & $\mathrm{~N} / \mathrm{S}$ \\
\hline $1-N A$ & 4,73 & 5,57 & 5,54 & 2,80 & 0,065 & $\mathrm{~N} / \mathrm{S}$ \\
\hline$\underline{6}-\mathrm{FHp}$ & 32,86 & 32,06 & 34,07 & 2,28 & 0,107 & $\mathrm{~N} / \mathrm{S}$ \\
\hline$\underline{6}-\mathrm{PP}$ & 18,26 & 18,27 & 19,19 & 2,94 & 0,057 & $\mathrm{~N} / \mathrm{S}$ \\
\hline \multicolumn{7}{|l|}{ Dentárias inferiores } \\
\hline$\overline{1 . N B}$ & 24,82 & 27,09 & 26,42 & 1,29 & 0,278 & $\mathrm{~N} / \mathrm{S}$ \\
\hline$\overline{1-N B}$ & 4,42 & 4,88 & 5,20 & 1,89 & 0,156 & $\mathrm{~N} / \mathrm{S}$ \\
\hline$\overline{6}-\mathrm{FHp}$ & 32,90 & 31,76 & 33,91 & 2,27 & 0,108 & N/S \\
\hline$\overline{6-G o M e ~}$ & 26,05 & 25,33 & 26,24 & 2,07 & 0,131 & $\mathrm{~N} / \mathrm{S}$ \\
\hline IMPA & 94,72 & 94,84 & 95,38 & 0,11 & 0,895 & $\mathrm{~N} / \mathrm{S}$ \\
\hline \multicolumn{7}{|l|}{ Tegumentares } \\
\hline ANL & 117,98 & 110,19 & 112,14 & 4,64 & 0,012 & Sig* \\
\hline Ls-Pog'Sn & 3,74 & 5,38 & 5,31 & 9,05 & 0,000 & Sig.** \\
\hline Li-Pog'Sn & 2,26 & 3,43 & 3,96 & 4,03 & 0,021 & Sig.* \\
\hline
\end{tabular}

$N / S=$ ão significante Sig. ${ }^{*}=$ significante $(p \leq 0,05)$ Sig. ${ }^{* *}=$ significante $(p \leq 0,01)$ 
TABELA 5 - Teste de Tukey entre os grupos 1 e 2 para comparação das medidas iniciais das variáveis estatisticamente significantes verificadas pela análise de variância.

\begin{tabular}{|c|c|c|c|c|}
\hline \multirow{2}{*}{$\begin{array}{l}\text { GRANDEZAS } \\
\text { CEFALOMÉTRICAS }\end{array}$} & \multicolumn{2}{|c|}{ MÉDIAS DAS MEDIDAS INICIAIS } & \multirow{2}{*}{$\begin{array}{c}\text { TESTE DE TUKEY } \\
\mathbf{P} \\
\end{array}$} & \multirow{2}{*}{ SIG. } \\
\hline & GRUPO 1 & GRUPO 2 & & \\
\hline \multicolumn{5}{|l|}{ Maxilar } \\
\hline Co-A & 81,02 & 78,83 & 0,555 & $\mathrm{~N} / \mathrm{S}$ \\
\hline \multicolumn{5}{|l|}{ Mandibular } \\
\hline Co-Gn & 99,25 & 96,96 & 0,099 & $\mathrm{~N} / \mathrm{S}$ \\
\hline \multicolumn{5}{|l|}{ Vertical } \\
\hline S-Go & 64,19 & 61,15 & 0,009 & Sig** $^{* *}$ \\
\hline \multicolumn{5}{|l|}{ Tegumentares } \\
\hline ANL & 117,98 & 110,19 & 0,012 & Sig* \\
\hline Ls-Pog'Sn & 3,74 & 5,38 & 0,000 & Sig.** \\
\hline Li-Pog'Sn & 2,26 & 3,43 & 0,144 & $\mathrm{~N} / \mathrm{S}$ \\
\hline
\end{tabular}

$N / S=$ não significante

Sig. ${ }^{*}=$ significante $(p \leq 0,05) \quad$ Sig. ${ }^{* *}=$ significante $(p \leq 0,01)$

TABELA 6 - Teste de Tukey entre os grupos 1 e 3 para comparação das medidas iniciais das variáveis estatisticamente significantes verificadas pela análise de variância.

\begin{tabular}{|c|c|c|c|c|}
\hline \multirow{2}{*}{$\begin{array}{l}\text { GRANDEZAS } \\
\text { CEFALOMÉTRICAS }\end{array}$} & \multicolumn{2}{|c|}{ MÉDIAS DAS MEDIDAS INICIAIS } & \multirow{2}{*}{$\begin{array}{c}\text { TESTE DE TUKEY } \\
\mathbf{P}\end{array}$} & \multirow{2}{*}{ SIG. } \\
\hline & GRUPO 1 & GRUPO 3 & & \\
\hline \multicolumn{5}{|l|}{ Maxilar } \\
\hline Co-A & 81,02 & 82,28 & 0,375 & $\mathrm{~N} / \mathrm{S}$ \\
\hline \multicolumn{5}{|l|}{ Mandibular } \\
\hline Co-Gn & 99,25 & 100,31 & 0,602 & $\mathrm{~N} / \mathrm{S}$ \\
\hline \multicolumn{5}{|l|}{ Vertical } \\
\hline S-Go & 64,19 & 64,73 & 0,851 & $\mathrm{~N} / \mathrm{S}$ \\
\hline \multicolumn{5}{|l|}{ Tegumentares } \\
\hline ANL & 117,98 & 112,14 & 0,077 & $\mathrm{~N} / \mathrm{S}$ \\
\hline Ls-Pog'Sn & 3,74 & 5,31 & 0,001 & Sig.** \\
\hline Li-Pog'Sn & 2,26 & 3,96 & 0,018 & Sig.* \\
\hline
\end{tabular}

$N / S=$ não significante

Sig. ${ }^{*}=$ significante $(p \leq 0,05) \quad$ Sig. ${ }^{* *}=$ significante $(p \leq 0,01)$ 
TABELA 7 - Teste de Tukey entre os grupos 2 e 3 para comparação das medidas iniciais das variáveis estatisticamente significantes verificadas pela análise de variância.

\begin{tabular}{|c|c|c|c|c|}
\hline \multirow{2}{*}{$\begin{array}{l}\text { GRANDEZAS } \\
\text { CEFALOMÉTRICAS }\end{array}$} & \multicolumn{2}{|c|}{ MÉDIAS DAS MEDIDAS INICIAIS } & \multirow{2}{*}{$\begin{array}{c}\text { TESTE DE TUKEY } \\
\text { P }\end{array}$} & \multirow{2}{*}{ SIG. } \\
\hline & GRUPO 2 & GRUPO 3 & & \\
\hline \multicolumn{5}{|l|}{ Maxilar } \\
\hline Co-A & 78,83 & 82,28 & 0,001 & Sig.** \\
\hline \multicolumn{5}{|l|}{ Mandibular } \\
\hline Co-Gn & 96,96 & 100,31 & 0,008 & Sig** $^{* *}$ \\
\hline \multicolumn{5}{|l|}{ Vertical } \\
\hline S-Go & 61,15 & 64,73 & 0,001 & Sig** $^{* *}$ \\
\hline \multicolumn{5}{|l|}{ Tegumentares } \\
\hline ANL & 110,19 & 112,14 & 0,745 & $\mathrm{~N} / \mathrm{S}$ \\
\hline Ls-Pog'Sn & 5,38 & 5,31 & 0,985 & $\mathrm{~N} / \mathrm{S}$ \\
\hline Li-Pog'Sn & 3,43 & 3,96 & 0,657 & $\mathrm{~N} / \mathrm{S}$ \\
\hline
\end{tabular}

$N / S=$ não significante $\quad$ Sig. ${ }^{*}=$ significante $(p \leq 0,05) \quad$ Sig. ${ }^{* *}=$ significante $(p \leq 0,01)$ 


\section{3 - COMPARAÇÃO INTERGRUPOS DAS ALTERAÇÕES MÉDIAS PELA} ANÁLISE DE VARIÂNCIA - ANOVA (Tabela 8).

$\mathrm{Na}$ tabela 8 observa-se que a maioria das grandezas cefalométricas obteve diferenças estatisticamente significantes, comprovando deste modo, que as alterações médias entre os três grupos mostraram-se bastante distintas.

A seguir serão representadas graficamente as medidas que não apresentaram diferenças estatísticas entre os três grupos. 
TABELA 8 - Análise de Variância (ANOVA) entre os 3 grupos das diferenças das médias das alterações iniciais e finais.

\begin{tabular}{|c|c|c|c|c|c|c|}
\hline \multirow{2}{*}{$\begin{array}{l}\text { GRANDEZAS } \\
\text { CEFALOMÉTRICAS }\end{array}$} & \multicolumn{3}{|c|}{$\begin{array}{c}\text { DIFERENÇA DAS MEDIAS DAS } \\
\text { ALTERAÇÕES }\end{array}$} & \multicolumn{2}{|c|}{ ANÁLISE DE VARIÂNCIA } & \multirow{2}{*}{ SIG. } \\
\hline & GRUPO 1 & GRUPO 2 & GRUPO 3 & $\mathbf{F}$ & $\mathbf{P}$ & \\
\hline \multicolumn{7}{|l|}{ Maxilares } \\
\hline SNA & $-0,49$ & $-1,48$ & $-0,34$ & 8,83 & 0,000 & Sig. ** \\
\hline Nperp-A & $-0,77$ & $-1,38$ & $-0,35$ & 6,37 & 0,002 & Sig.** \\
\hline Co-A & 2,33 & 1,72 & 0,81 & 3,08 & 0,050 & Sig.* \\
\hline \multicolumn{7}{|l|}{ Mandibulares } \\
\hline SNB & $-0,18$ & 0,46 & 1,23 & 9,77 & 0,000 & Sig. ${ }^{* *}$ \\
\hline Nperp-P & $-0,83$ & 0,44 & 1,23 & 5,37 & 0,006 & Sig. ** \\
\hline Go-Gn & 2,57 & 3,35 & 2,33 & 1,88 & 0,158 & $N / S$ \\
\hline Co-Gn & 3,23 & 5,29 & 4,15 & 2,85 & 0,062 & N/S \\
\hline \multicolumn{7}{|l|}{ Maxilomandibular } \\
\hline ANB & $-0,45$ & $-1,95$ & $-1,55$ & 12,01 & 0,000 & Sig.** \\
\hline NAP & $-0,86$ & $-4,42$ & $-2,90$ & 15,42 & 0,000 & Sig. ** \\
\hline \multicolumn{7}{|l|}{ Verticais } \\
\hline SN.GoGn & $-0,36$ & $-0,19$ & 0,22 & 0,93 & 0,394 & $N / S$ \\
\hline SN.PP & 0,77 & 0,89 & 0,44 & 0,84 & 0,432 & $N / S$ \\
\hline AFAI & 1,45 & 2,38 & 2,59 & 2,56 & 0,082 & $\mathrm{~N} / \mathrm{S}$ \\
\hline S-Go & 2,76 & 3,66 & 3,70 & 1,67 & 0,193 & $N / S$ \\
\hline \multicolumn{7}{|c|}{ Dentárias superiores } \\
\hline 1.NA & 0,68 & $-9,26$ & $-4,48$ & 28,61 & 0,000 & Sig.** \\
\hline $1-N A$ & 0,48 & $-1,77$ & $-0,69$ & 14,87 & 0,000 & Sig. ${ }^{* *}$ \\
\hline$\underline{6}-\mathrm{FHp}$ & 0,92 & $-1,27$ & 0,10 & 6,98 & 0,015 & Sig.* \\
\hline$\underline{6}-\mathrm{PP}$ & 1,19 & 0,69 & 0,88 & 0,91 & 0,403 & $\mathrm{~N} / \mathrm{S}$ \\
\hline \multicolumn{7}{|l|}{ Dentárias inferiores } \\
\hline$\overline{1 . N B}$ & 0,33 & $-2,22$ & 4,25 & 20,35 & 0,000 & Sig.** \\
\hline 1-NB & 0,24 & $-0,22$ & 1,12 & 14,66 & 0,000 & Sig. ${ }^{* *}$ \\
\hline$\overline{6}-\mathrm{FHp}$ & 1,05 & 2,69 & 3,27 & 10,09 & 0,000 & Sig.** \\
\hline 6-GoMe & 0,79 & 1,78 & 1,55 & 5,79 & 0,004 & Sig. ** \\
\hline IMPA & 1,00 & $-2,48$ & 2,79 & 15,42 & 0,000 & Sig.** \\
\hline \multicolumn{7}{|l|}{ Tegumentares } \\
\hline ANL & 0,20 & 1,88 & $-0,21$ & 0,56 & 0,568 & $\mathrm{~N} / \mathrm{S}$ \\
\hline Ls-Pog'Sn & 0,05 & $-1,50$ & $-0,69$ & 14,98 & 0,000 & Sig. ** \\
\hline Li-Pog'Sn & 0,39 & $-0,93$ & 0,38 & 9,07 & 0,000 & Sig. ** \\
\hline
\end{tabular}


O comprimento efetivo mandibular, expresso pelas medidas lineares Co-Gn e Go-Gn aumentou nos três grupos, revelando-se sensivelmente maior nos grupos tratados (Figuras 7 e 8) porém sem denotar uma diferença estatisticamente significante.

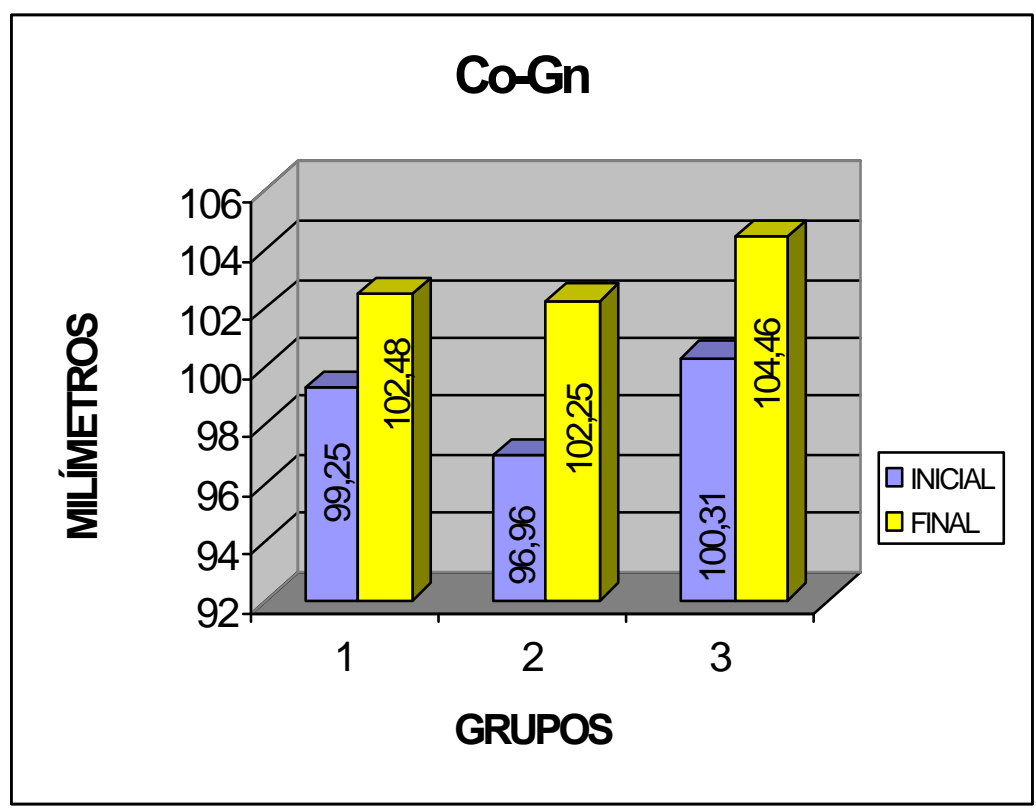

FIGURA 7- Valores médios iniciais e finais para os três grupos da grandeza Co-Gn.

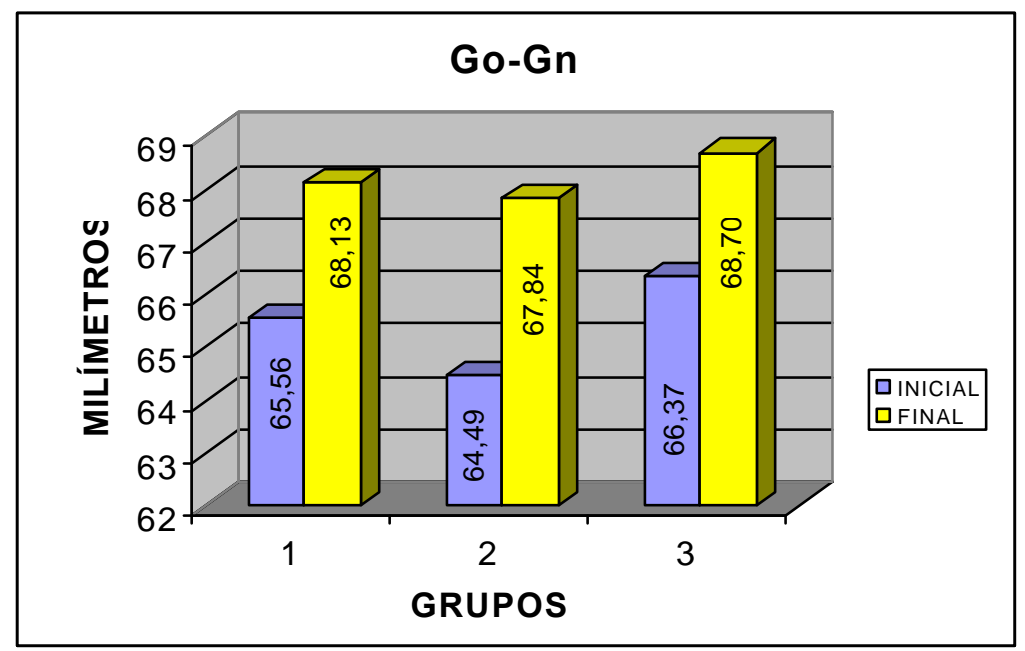

FIGURA 8- Valores médios iniciais e finais para os três grupos da grandeza Go-Gn. 
Os ângulos SN.GoGn e SN.PP foram escolhidos para verificar o padrão de crescimento facial. Nenhuma medida demonstrou alteração significante entre os grupos (Figuras 9 e 10), embora nos grupos 1 e 2 tenha se verificado uma tendência ao fechamento do ângulo do plano mandibular, enquanto que no grupo 3 ocorreu um discreto aumento (Figura 9).

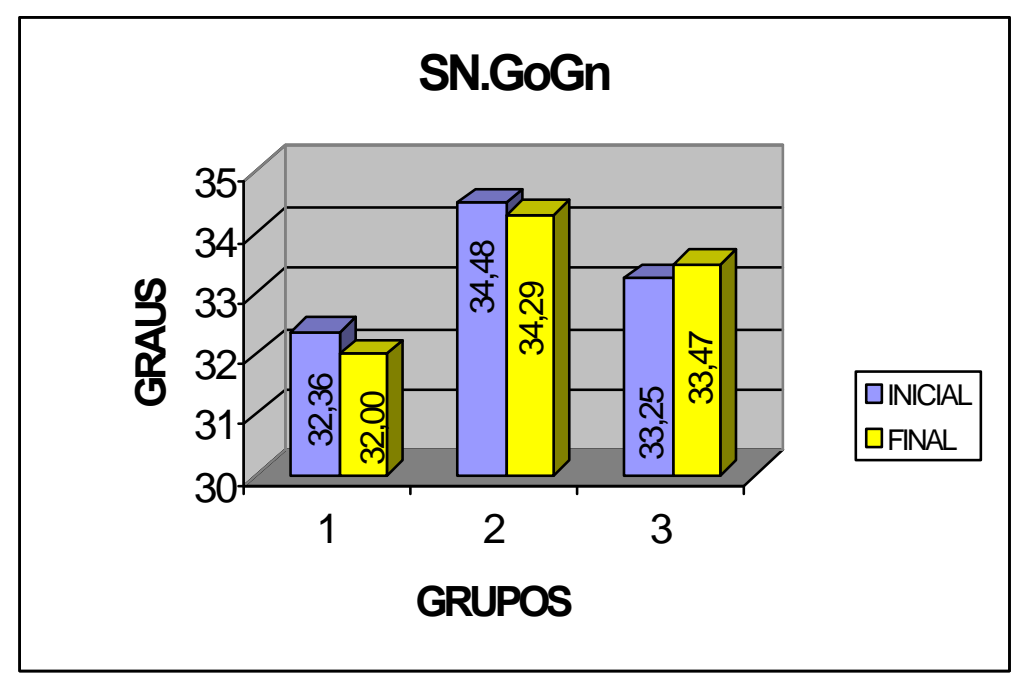

FIGURA 9- Valores médios iniciais e finais para os três grupos da grandeza SN.GoGn.

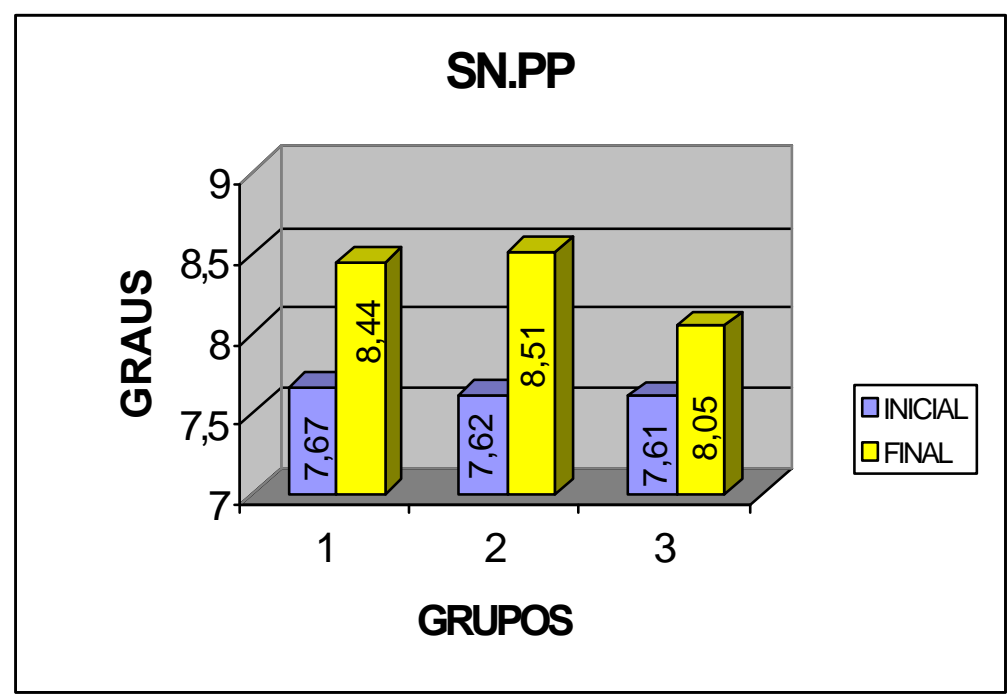

FIGURA 10- Valores médios iniciais e finais para os três grupos da grandeza SN.PP. 
A AFAl e a medida S-Go possibilitaram a verificação das alterações no sentido vertical da face, onde se notou um comportamento uniforme no aumento destas grandezas nos três grupos, sem denotar diferença estatística (Figuras 11 e 12).

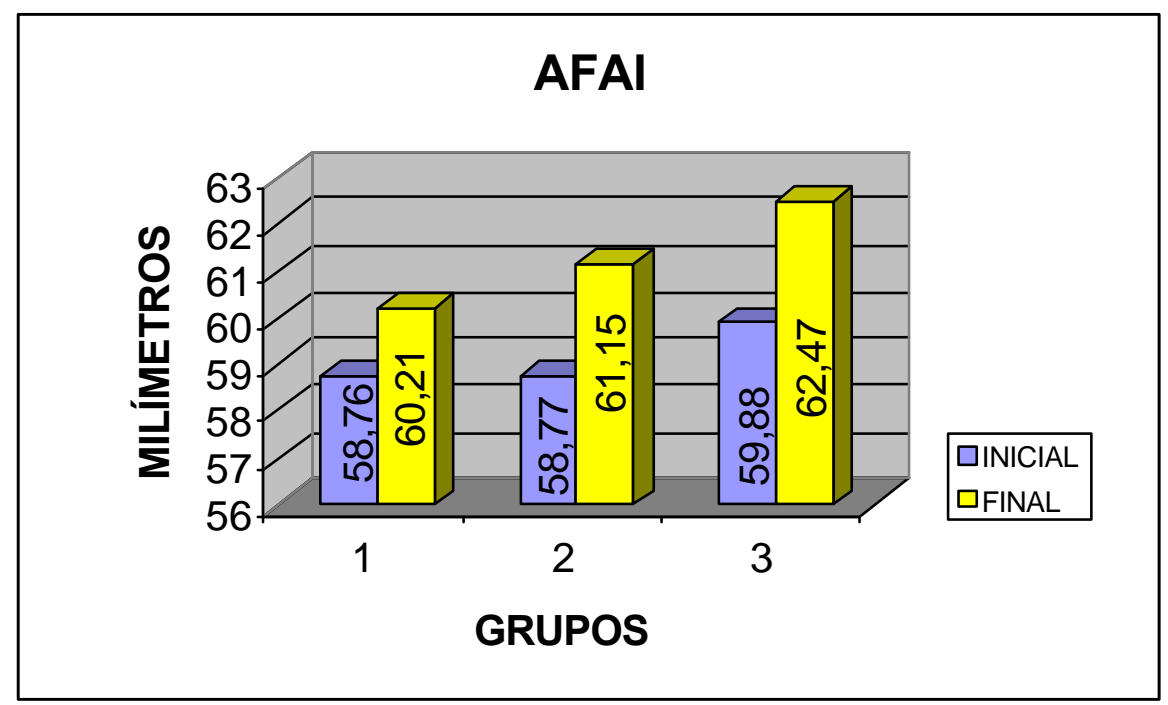

FIGURA 11- Valores médios iniciais e finais para os três grupos da grandeza AFAI.

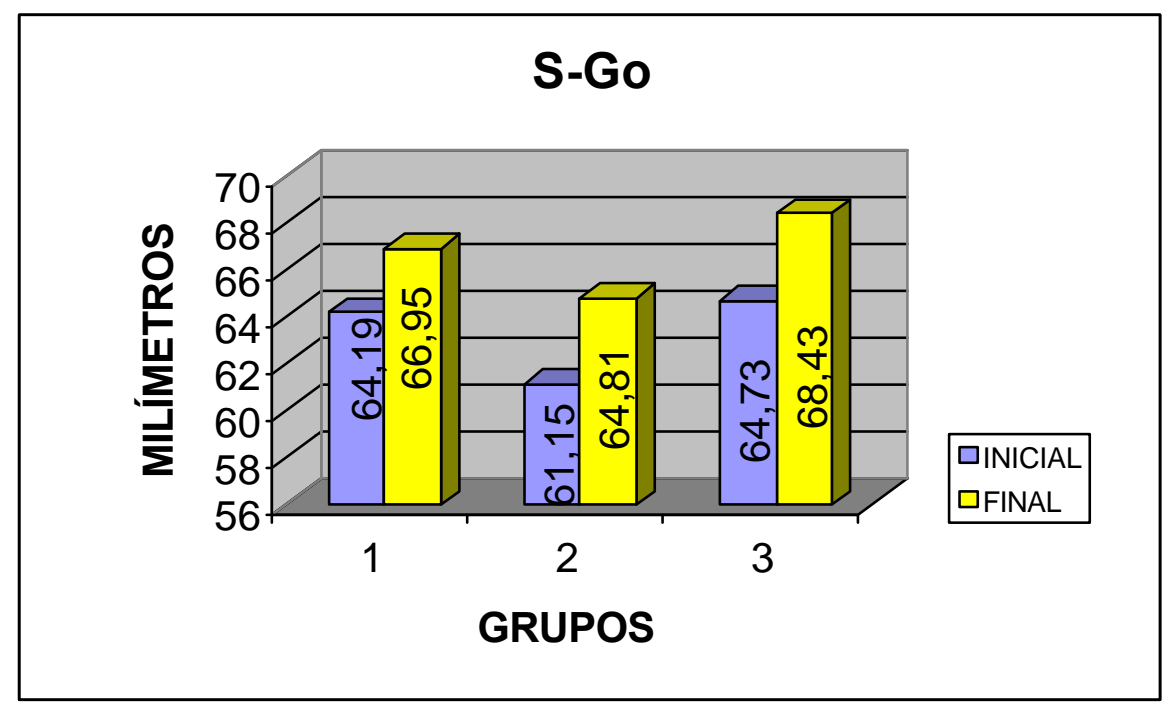

FIGURA 12- Valores médios iniciais e finais para os três grupos da grandeza S-Go. 
Em relação ao componente dentoalveolar, apenas a grandeza $\underline{6}$-PP não apresentou diferença estatisticamente significante.

O posicionamento vertical dos molares superiores, demonstrou extrusão similar nos três grupos, não obstante ocorreu um menor aumento nos grupos interceptados com os aparelhos AEB conjugado e Bionator de Balters (Figura 13).

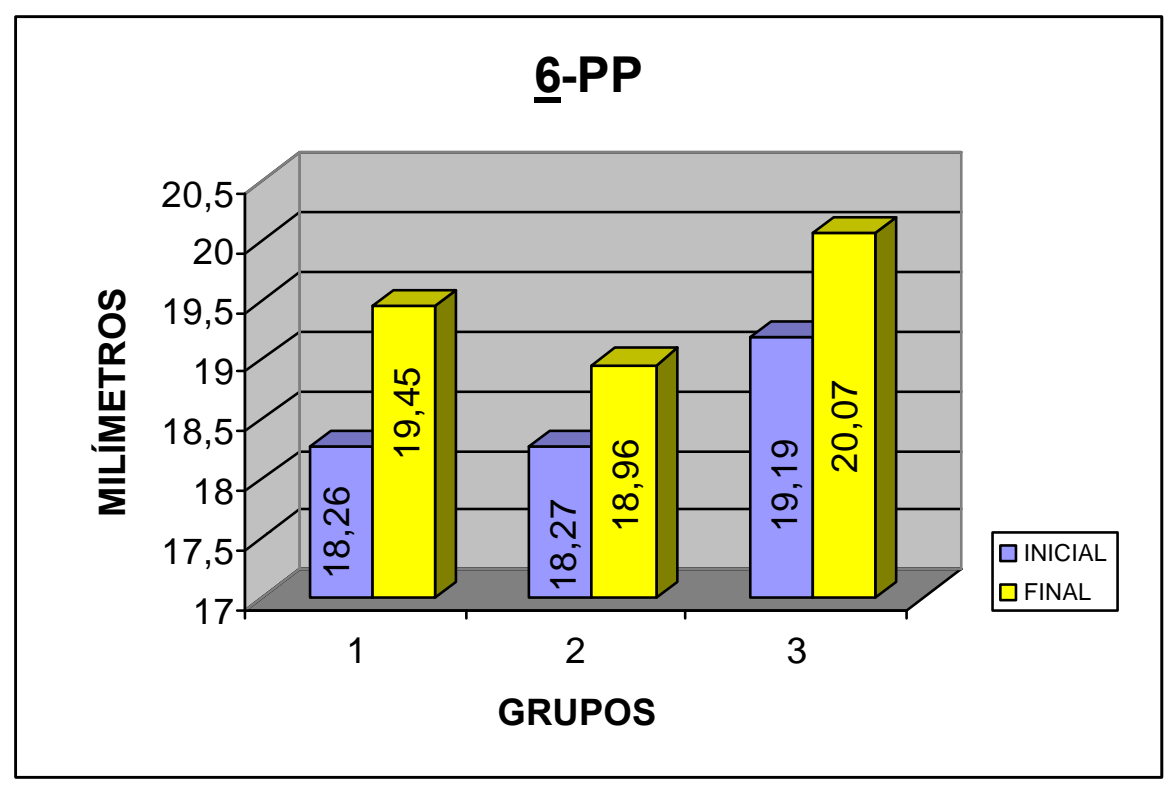

FIGURA 13- Valores médios iniciais e finais para os três grupos da grandeza $\underline{6}-\mathrm{PP}$. 
Utilizou-se para avaliação do perfil facial, o ângulo nasolabial (ANL) e as distâncias dos lábios superior e inferior a linha Pog'Sn. Deste modo, verificou-se que a grandeza ANL não demonstrou diferença estatisticamente significante entre os grupos (Figura 14). Os grupos 1 e 2 mostraram um aumento do ângulo nasolabial enquanto que o grupo 3 experimentou uma diminuição desta grandeza, ambos sem diferença estatística.

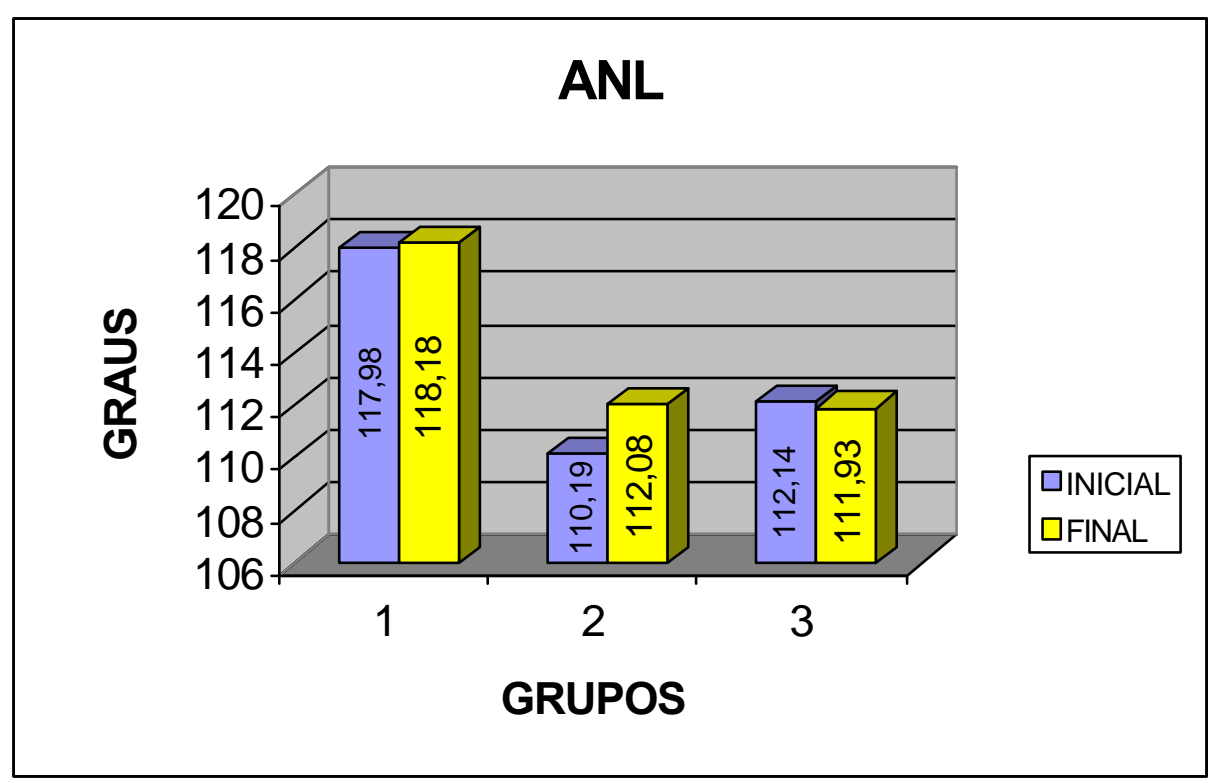

FIGURA 14- Valores médios iniciais e finais para os três grupos da grandeza ANL. 
Com 0 intento de expor os resultados que obtiveram diferenças estatisticamente significantes e para que se compare as diferentes respostas entre os grupos, identificando aquele que possui os valores responsáveis pela diferença estatística, foi efetuado o teste de Tukey, confrontando os três grupos entre si (Tabelas 9, 10 e 11).

A seguir serão representadas graficamente as grandezas cefalométricas que apresentaram diferenças estatisticamente significantes entre os grupos.

Ressalta-se que os valores que exprimem as alterações ocorridas na relação vertical, traduzidas pelas grandezas SN.GoGn, SN.PP, AFAI e S-Go não denotaram diferenças estatísticas significantes entre os grupos, representando um comportamento similar dos grupos, interceptados ou não pelo tratamento (Figuras 9 a 12). 
TABELA 9 - Comparação das médias das alterações entre os grupos 1 e 2 utilizando o teste de Tukey para as grandezas estatisticamente significantes verificadas pela análise de variância.

\begin{tabular}{|c|c|c|c|c|}
\hline \multirow{2}{*}{$\begin{array}{l}\text { GRANDEZAS } \\
\text { CEFALOMÉTRICAS }\end{array}$} & \multicolumn{2}{|c|}{ (MÉDIAS DAS ALTERAÇÕES) } & \multirow{2}{*}{$\begin{array}{c}\text { TESTE TUKEY } \\
\text { P }\end{array}$} & \multirow{2}{*}{ SIG. } \\
\hline & GRUPO 1 & GRUPO 2 & & \\
\hline \multicolumn{5}{|l|}{ Maxilares } \\
\hline SNA & $-0,49$ & $-1,48$ & 0,003 & Sig.** \\
\hline Nperp-A & $-0,77$ & $-1,38$ & 0,091 & $\mathrm{~N} / \mathrm{S}$ \\
\hline Co-A & 2,33 & 1,72 & 0,588 & $\mathrm{~N} / \mathrm{S}$ \\
\hline \multicolumn{5}{|l|}{ Mandibulares } \\
\hline SNB & $-0,18$ & 0,46 & 0,118 & $\mathrm{~N} / \mathrm{S}$ \\
\hline Nperp-P & $-0,83$ & 0,44 & 0,118 & $\mathrm{~N} / \mathrm{S}$ \\
\hline \multicolumn{5}{|l|}{ Maxilomandibular } \\
\hline ANB & $-0,45$ & $-1,95$ & 0,000 & Sig.** \\
\hline NAP & $-0,86$ & $-4,42$ & 0,000 & Sig.** \\
\hline \multicolumn{5}{|c|}{ Dentárias superiores } \\
\hline 1.NA & 0,68 & $-9,26$ & 0,000 & Sig.** \\
\hline $1-\mathrm{NA}$ & 0,48 & $-1,77$ & 0,000 & Sig.** \\
\hline$\underline{6}-\mathrm{FHp}$ & 0,92 & $-1,27$ & 0,001 & Sig.** \\
\hline \multicolumn{5}{|l|}{ Dentárias inferiores } \\
\hline$\overline{1 . N B}$ & 0,33 & $-2,22$ & 0,037 & Sig.* \\
\hline$\overline{1-N B}$ & 0,24 & $-0,22$ & 0,163 & $\mathrm{~N} / \mathrm{S}$ \\
\hline$\overline{6}-\mathrm{FHp}$ & 1,05 & 2,69 & 0,005 & Sig.** \\
\hline$\overline{6}$-GoMe & 0,79 & 1,78 & 0,004 & Sig.** \\
\hline IMPA & 1,00 & $-2,48$ & 0,001 & Sig.** \\
\hline \multicolumn{5}{|l|}{ Tegumentares } \\
\hline Ls-Pog'Sn & 0,05 & $-1,50$ & 0,000 & Sig.** \\
\hline Li-Pog'Sn & 0,39 & $-0,93$ & 0,001 & Sig.** \\
\hline
\end{tabular}


TABELA 10 - Comparação das médias das alterações entre os grupos 1 e 3 utilizando o teste de Tukey para as grandezas estatisticamente significantes verificadas pela análise de variância.

\begin{tabular}{|c|c|c|c|c|}
\hline \multirow{2}{*}{$\begin{array}{l}\text { GRANDEZAS } \\
\text { CEFALOMÉTRICAS }\end{array}$} & \multicolumn{2}{|c|}{ (MÉDIAS DAS ALTERAÇÕES) } & \multirow{2}{*}{$\begin{array}{c}\text { TESTE TUKEY } \\
\text { P }\end{array}$} & \multirow{2}{*}{ SIG. } \\
\hline & GRUPO 1 & GRUPO 3 & & \\
\hline \multicolumn{5}{|l|}{ Maxilares } \\
\hline SNA & $-0,49$ & $-0,34$ & 0,873 & $\mathrm{~N} / \mathrm{S}$ \\
\hline Nperp-A & $-0,77$ & $-0,35$ & 0,331 & $\mathrm{~N} / \mathrm{S}$ \\
\hline Co-A & 2,33 & 0,81 & 0,040 & Sig. ${ }^{*}$ \\
\hline \multicolumn{5}{|l|}{ Mandibulares } \\
\hline SNB & $-0,18$ & 1,23 & 0,000 & Sig.** \\
\hline Nperp-P & $-0,83$ & 1,23 & 0,004 & Sig.** \\
\hline \multicolumn{5}{|l|}{ Maxilomandibular } \\
\hline ANB & $-0,45$ & $-1,55$ & 0,002 & Sig.** \\
\hline NAP & $-0,86$ & $-2,90$ & 0,006 & Sig. ** \\
\hline \multicolumn{5}{|c|}{ Dentárias superiores } \\
\hline 1.NA & 0,68 & $-4,48$ & 0,000 & Sig.** \\
\hline $1-\mathrm{NA}$ & 0,48 & $-0,69$ & 0,015 & Sig.* \\
\hline$\underline{6}-\mathrm{FHp}$ & 0,92 & 0,10 & 0,356 & N/S \\
\hline \multicolumn{5}{|l|}{ Dentárias inferiores } \\
\hline$\overline{1 . N B}$ & 0,33 & 4,25 & 0,000 & Sig.** \\
\hline$\overline{1}-\mathrm{NB}$ & 0,24 & 1,12 & 0,002 & Sig.** \\
\hline$\overline{6}-\mathrm{FHp}$ & 1,05 & 3,27 & 0,000 & Sig.** \\
\hline$\overline{6}$-GoMe & 0,79 & 1,55 & 0,037 & Sig.* \\
\hline IMPA & 1,00 & 2,79 & 0,158 & $\mathrm{~N} / \mathrm{S}$ \\
\hline \multicolumn{5}{|l|}{ Tegumentares } \\
\hline Ls-Pog'Sn & 0,05 & $-0,69$ & 0,027 & Sig.* \\
\hline Li-Pog'Sn & 0,39 & 0,38 & 0,999 & $\mathrm{~N} / \mathrm{S}$ \\
\hline
\end{tabular}


TABELA 11 - Comparação das médias das alterações entre os grupos 2 e 3 utilizando o teste de Tukey para as grandezas estatisticamente significantes verificadas pela análise de variância.

\begin{tabular}{|c|c|c|c|c|}
\hline \multirow{2}{*}{$\begin{array}{l}\text { GRANDEZAS } \\
\text { CEFALOMÉTRICAS }\end{array}$} & \multicolumn{2}{|c|}{ (MÉDIAS DAS ALTERAÇÕES) } & \multirow{2}{*}{$\begin{array}{c}\text { TESTE TUKEY } \\
\mathbf{P} \\
\end{array}$} & \multirow{2}{*}{ SIG. } \\
\hline & GRUPO 2 & GRUPO 3 & & \\
\hline \multicolumn{5}{|l|}{ Maxilares } \\
\hline SNA & $-1,48$ & $-0,34$ & 0,000 & Sig.** \\
\hline Nperp-A & $-1,38$ & $-0,35$ & 0,001 & Sig.** \\
\hline Co-A & 1,72 & 0,81 & 0,303 & $\mathrm{~N} / \mathrm{S}$ \\
\hline \multicolumn{5}{|l|}{ Mandibulares } \\
\hline SNB & 0,46 & 1,23 & 0,046 & Sig.* \\
\hline Nperp-P & 0,44 & 1,23 & 0,428 & $\mathrm{~N} / \mathrm{S}$ \\
\hline \multicolumn{5}{|l|}{ Maxilomandibular } \\
\hline ANB & $-1,95$ & $-1,55$ & 0,423 & $\mathrm{~N} / \mathrm{S}$ \\
\hline NAP & $-4,42$ & $-2,90$ & 0,052 & $\mathrm{~N} / \mathrm{S}$ \\
\hline \multicolumn{5}{|c|}{ Dentárias superiores } \\
\hline 1.NA & $-9,26$ & $-4,48$ & 0,001 & Sig.** \\
\hline $1-N A$ & $-1,77$ & $-0,69$ & 0,028 & Sig.* \\
\hline$\underline{6}-\mathrm{FHp}$ & $-1,27$ & 0,10 & 0,058 & $\mathrm{~N} / \mathrm{S}$ \\
\hline \multicolumn{5}{|l|}{ Dentárias inferiores } \\
\hline$\overline{1 . N B}$ & $-2,22$ & 4,25 & 0,000 & Sig.** \\
\hline$\overline{1}-\mathrm{NB}$ & $-0,22$ & 1,12 & 0,000 & Sig.** \\
\hline$\overline{6}-\mathrm{FHp}$ & 2,69 & 3,27 & 0,504 & $\mathrm{~N} / \mathrm{S}$ \\
\hline$\overline{6}$-GoMe & 1,78 & 1,55 & 0,734 & $\mathrm{~N} / \mathrm{S}$ \\
\hline IMPA & $-2,48$ & 2,79 & 0,000 & Sig.** \\
\hline \multicolumn{5}{|l|}{ Tegumentares } \\
\hline Ls-Pog'Sn & $-1,50$ & $-0,69$ & 0,014 & Sig.* \\
\hline Li-Pog'Sn & $-0,93$ & 0,38 & 0,001 & Sig.** \\
\hline
\end{tabular}

$N / S=$ não significante Sig. ${ }^{*}=$ significante $(p \leq 0,05) \quad$ Sig. ${ }^{* *}=$ significante $(p \leq 0,01)$ 
Para facilitar a compreensão dos resultados das comparações que obtiveram diferença estatística das alterações cefalométricas médias entre os três grupos, tanto lineares como angulares, dividiu-se em tópicos, destacando-se:

\subsection{1 - Componente maxilar}

5.3.2. - Componente mandibular;

5.3.3. - Relação maxilomandibular;

5.3.4. - Componente dentoalveolar e

5.3.5. - Perfil tegumentar.

\subsection{1. - Comparação das alterações no componente maxilar.}

Os valores que exprimem as alterações ocorridas no componente maxilar, traduzidas pelas grandezas SNA, Nperp-A, e Co-A demonstraram diferenças estatísticas significantes entre os grupos. O ângulo SNA e a medida linear Nperp-A que definem a posição da maxila em relação à base do crânio demonstraram uma retrusão da maxila nos três grupos estudados sendo esta diminuição maior no grupo 2 com diferença significante (Figuras 15 a 17). A medida Co-A aumentou em todos os grupos com diferença significante entre os grupos 1 e 3 (Tabela 10). 


\subsubsection{1 - Grupo 1 X Grupo 2 (Tabela 9)}

Confrontando os 2 grupos, verificou-se uma diminuição das medidas que avaliam o posicionamento maxilar em relação à base do crânio (SNA e Nperp-A), sugerindo uma restrição do crescimento da maxila para anterior (Figuras 15 e 16). Esta restrição ocorreu com maior intensidade no grupo tratado com 0 AEB conjugado, apresentando diferença estatística para o ângulo SNA. Avaliando o comprimento efetivo da maxila (Co-A), verificou-se um aumento semelhante nos 2 grupos sem significância estatística (Figura 17).

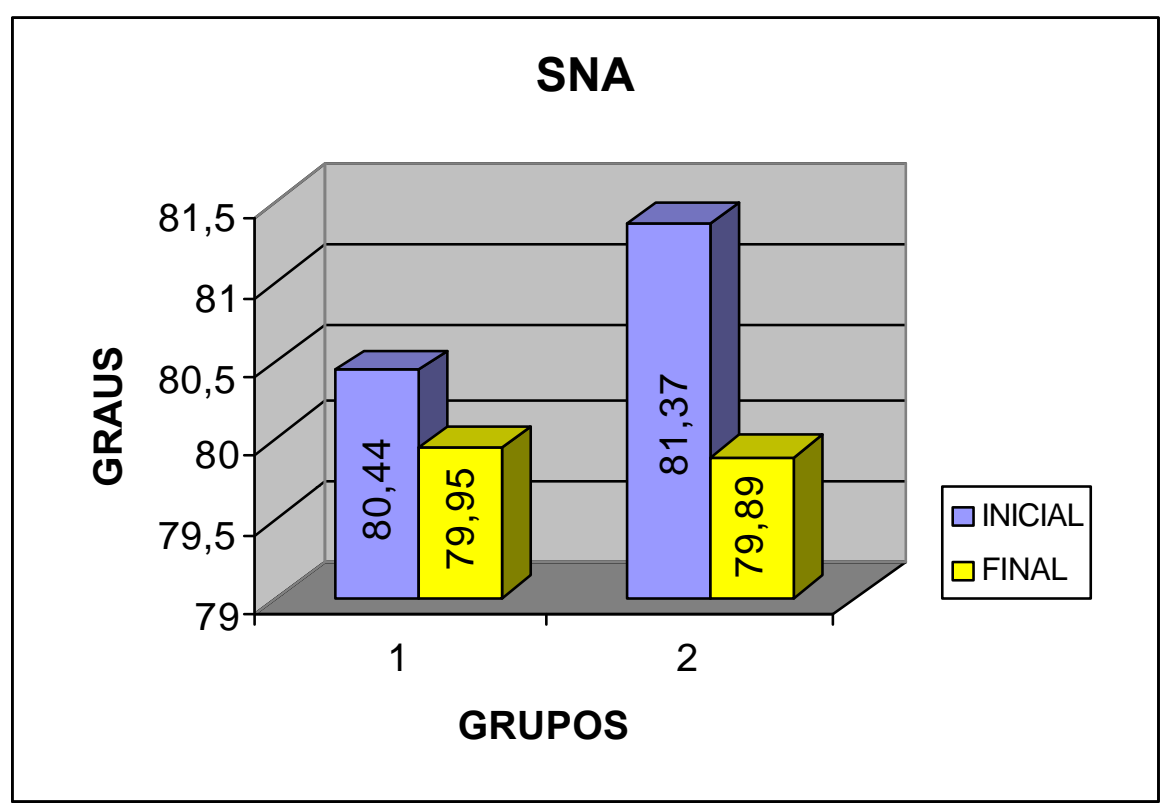

FIGURA 15- Valores médios iniciais e finais da grandeza SNA para os grupos 1 e 2. 


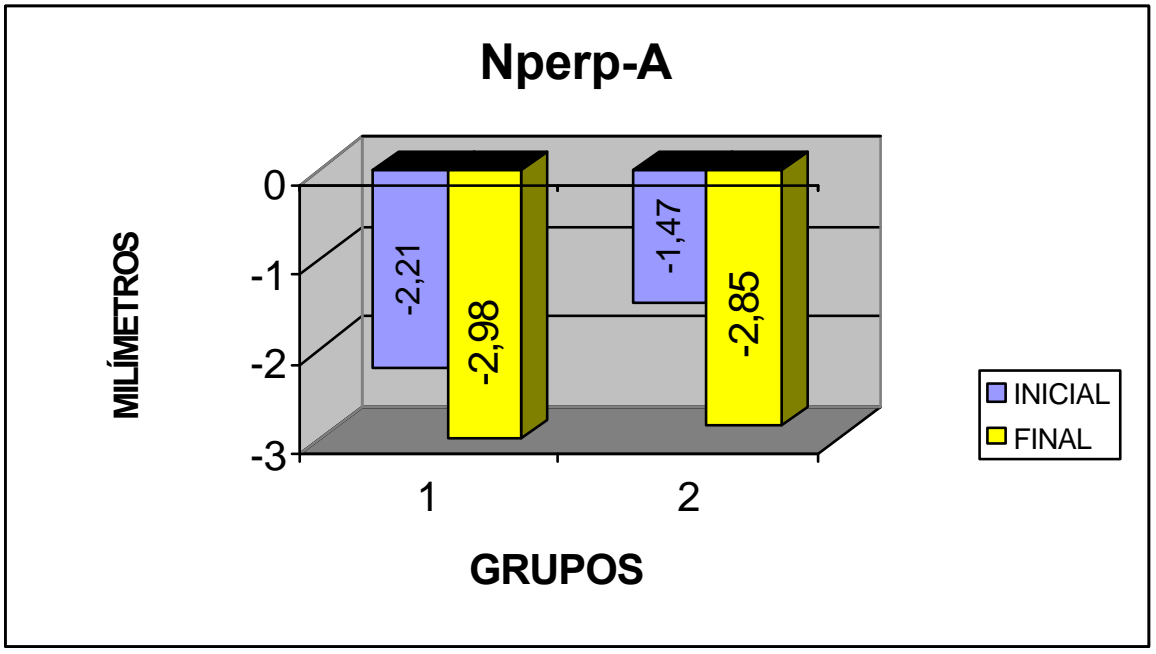

FIGURA 16- Valores médios iniciais e finais da grandeza Nperp-A para os grupos 1 e 2 .

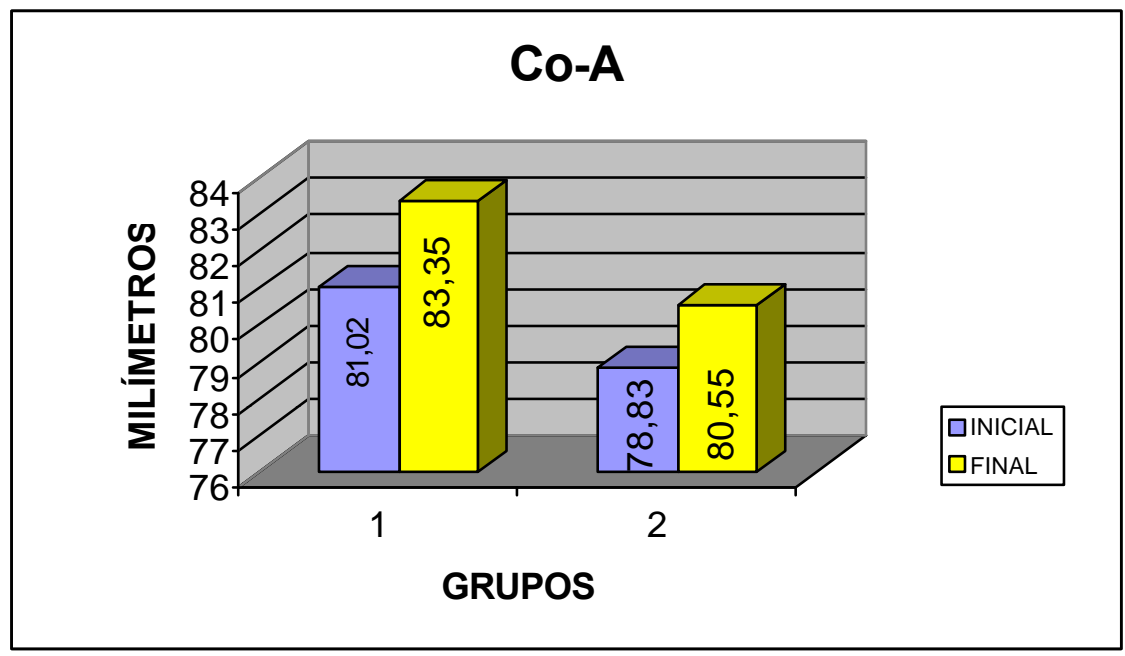

FIGURA 17- Valores médios iniciais e finais da grandeza Co-A para os grupos 1 e 2. 


\subsubsection{2 - Grupo 1 X Grupo 3 (Tabela 10)}

Ambos os grupos apresentaram retrusão maxilar, avaliando as grandezas SNA e Nperp-A porém sem diferença estatística (Figuras 18 e 19). Em relação ao comprimento efetivo da maxila (Co-A) observourse um aumento para ambos os grupos, no entanto com menor intensidade para o grupo 3 (Figura 20) denotando diferença estatística.

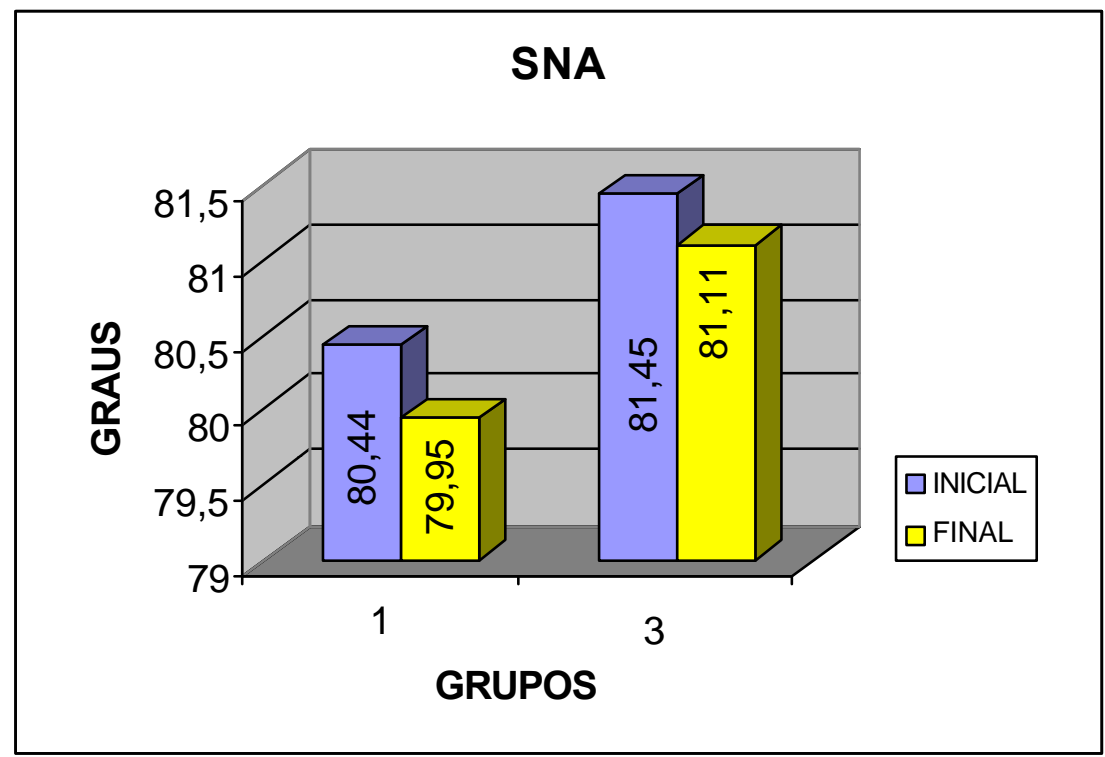

FIGURA 18- Valores médios iniciais e finais da grandeza SNA para os grupos 1 e 3.

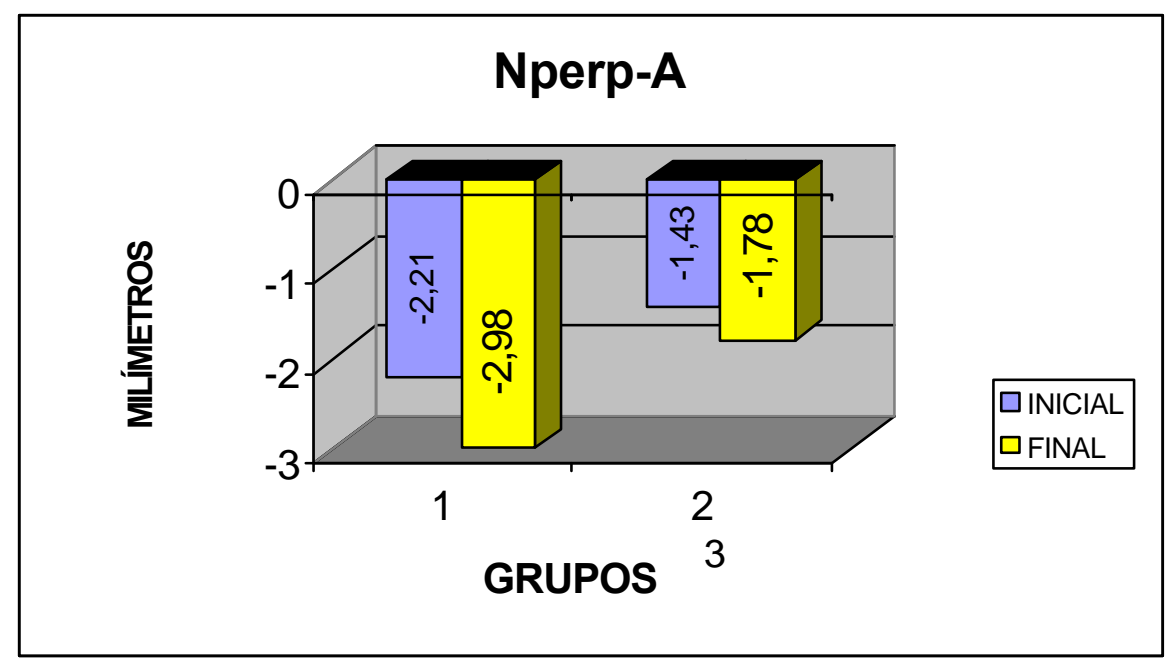

FIGURA 19- Valores médios iniciais e finais da grandeza Nperp-A para os grupos 1 e 3. 


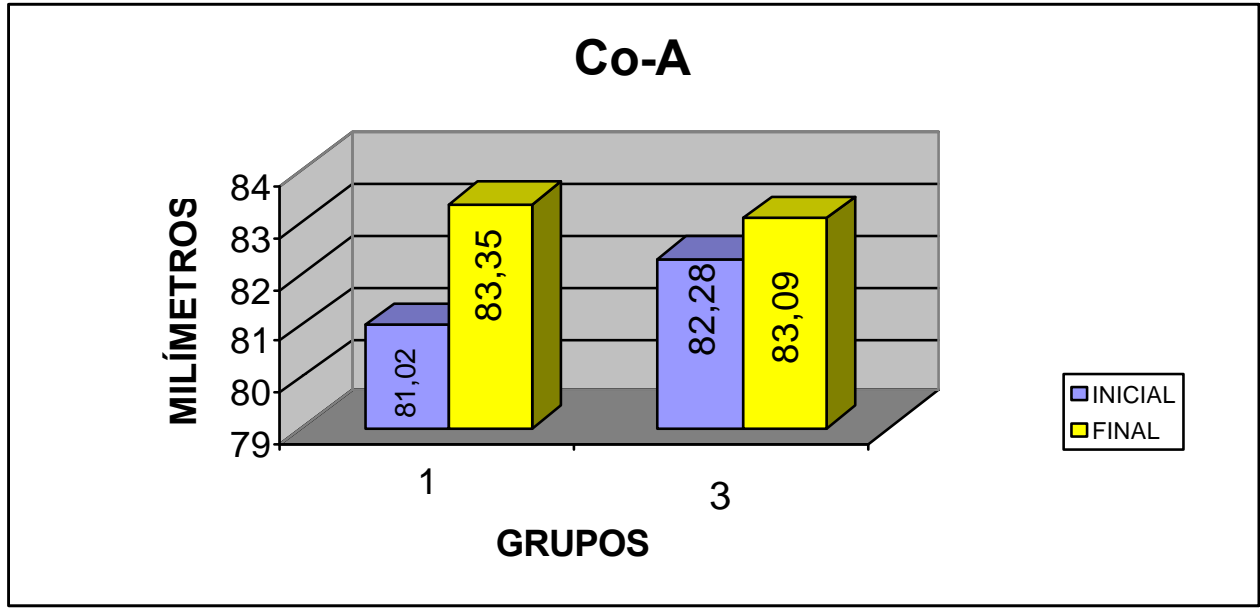

FIGURA 20- Valores médios iniciais e finais da grandeza Co-A para os grupos 1 e 3.

\subsubsection{3 - Grupo 2 X Grupo 3 (Tabela 11)}

Comparando os grupos tratados verificou-se uma retrusão maxilar para ambos, porém mais significante no grupo interceptado com o AEB conjugado, denotando diferença estatística ao nível de 1\% Figuras 21 e 22). Em relação a medida Co-A observou-se um aumento semelhante nos 2 grupos sem significado estatístico (Figura 23).

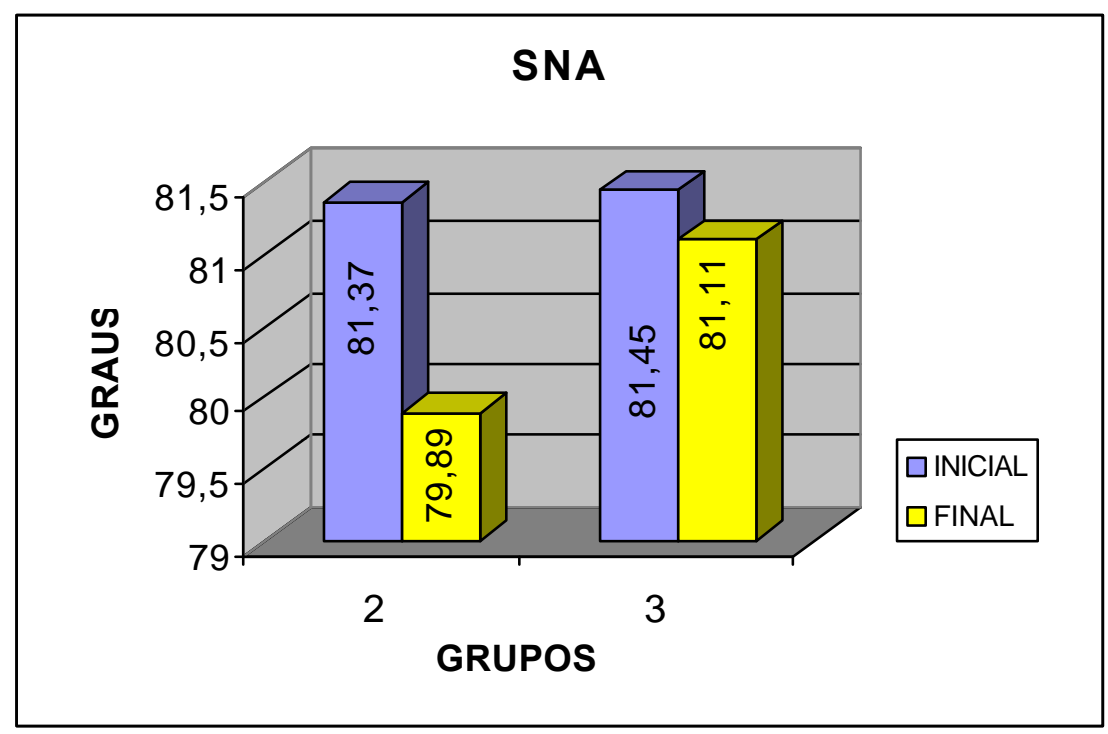

FIGURA 21- Valores médios iniciais e finais da grandeza SNA para os grupos 2 e 3. 


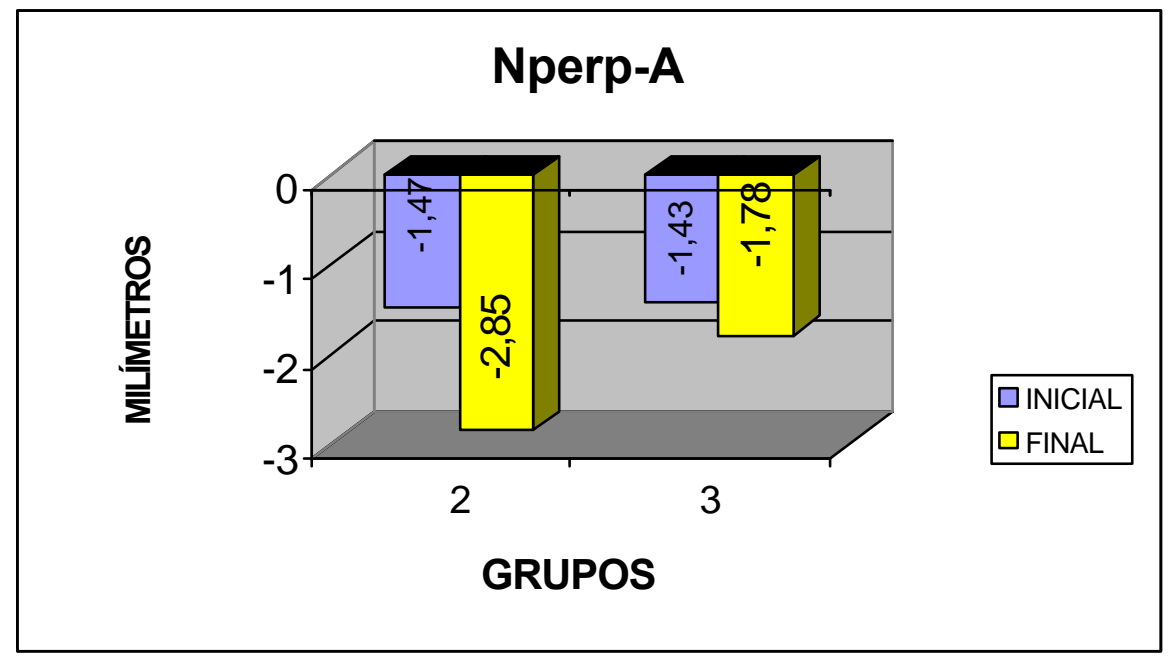

FIGURA 22- Valores médios iniciais e finais da grandeza Nperp-A para os grupos 2 e 3.

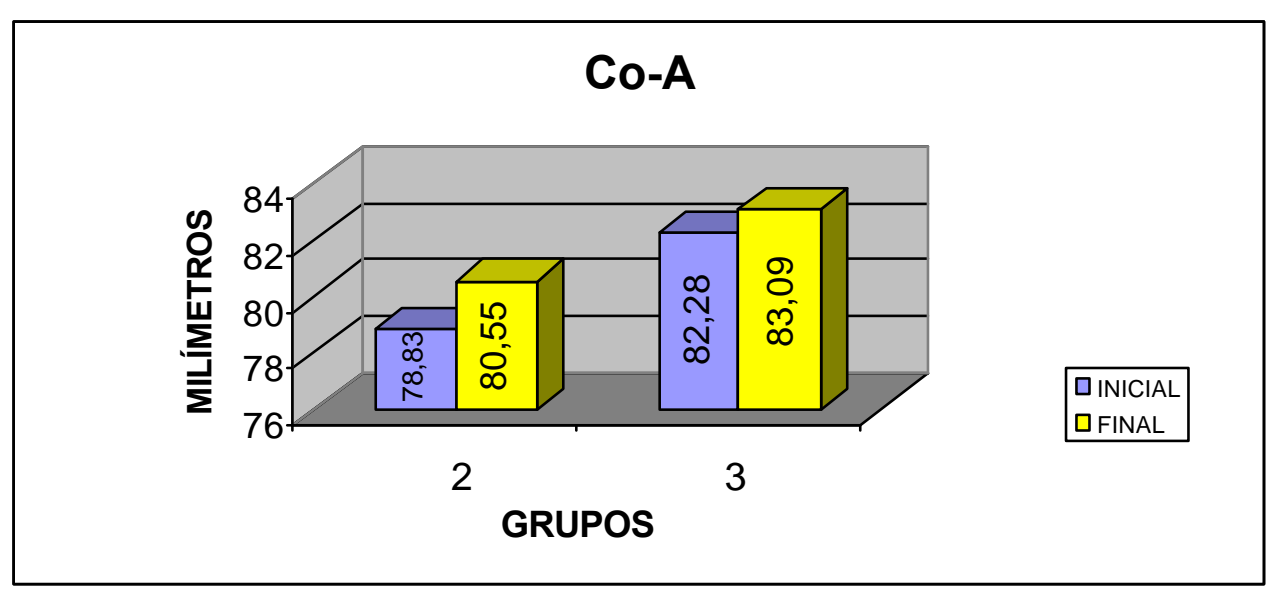

FIGURA 23- Valores médios iniciais e finais da grandeza Co-A para os grupos 2 e 3. 


\subsection{2. - Comparação das alterações no componente mandibular.}

Apenas as medidas que avaliam o posicionamento mandibular em relação à base do crânio apresentaram diferenças estatisticamente significantes (SNB e Nperp-P). O valor de SNB e Nperp-P mostrou aumento apenas nos grupos tratados, com significância estatística (Tabelas 9 e 10).

\subsubsection{1 - Grupo 1 X Grupo 2 (Tabela 9)}

Avaliando as medidas SNB e Nperp-P verificou-se um comportamento distinto entre os grupos porém sem diferença estatisticamente significante. O grupo tratado apresentou uma protrusão mandibular enquanto o grupo controle mostrou uma diminuição destas medidas sugerindo retrusão da mandíbula (Figuras 24 e 25).

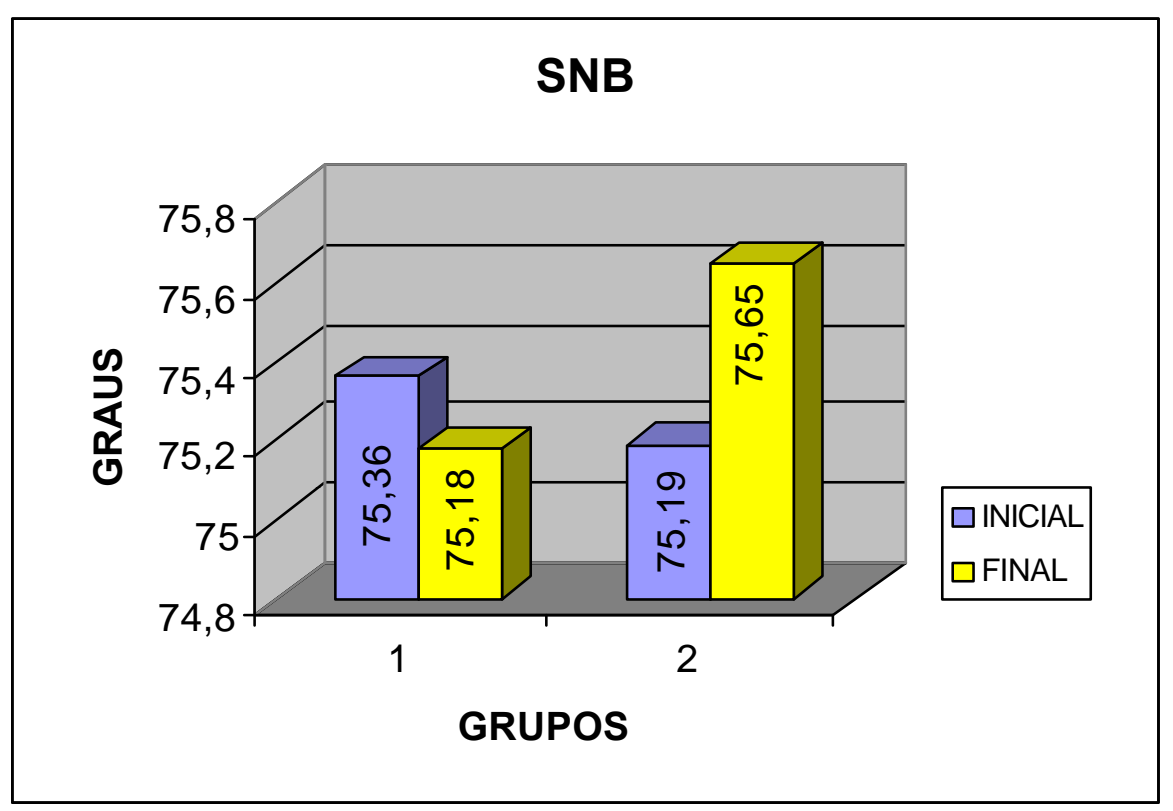

FIGURA 24- Valores médios iniciais e finais da grandeza SNB para os grupos 1 e 2. 


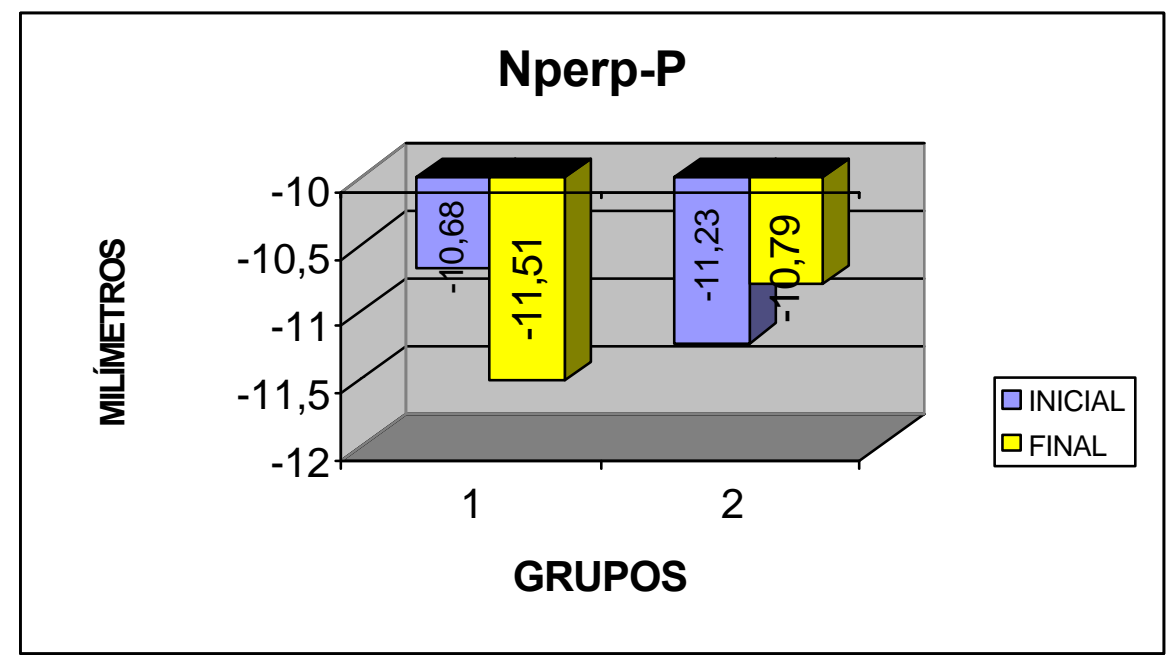

FIGURA 25- Valores médios iniciais e finais da grandeza Nperp-P para os grupos 1 e 2

\subsubsection{2 - Grupo 1 X Grupo 3 (Tabela 10)}

Confrontando-se os grupos controle e tratado com o Bionator de Balters, verificourse uma protrusão mandibular (SNB e Nperp-P) no grupo 3, e retrusão da mandíbula no grupo 1, o que determinou significância estatística ao nível de 1\% (Figuras 26 e 27).

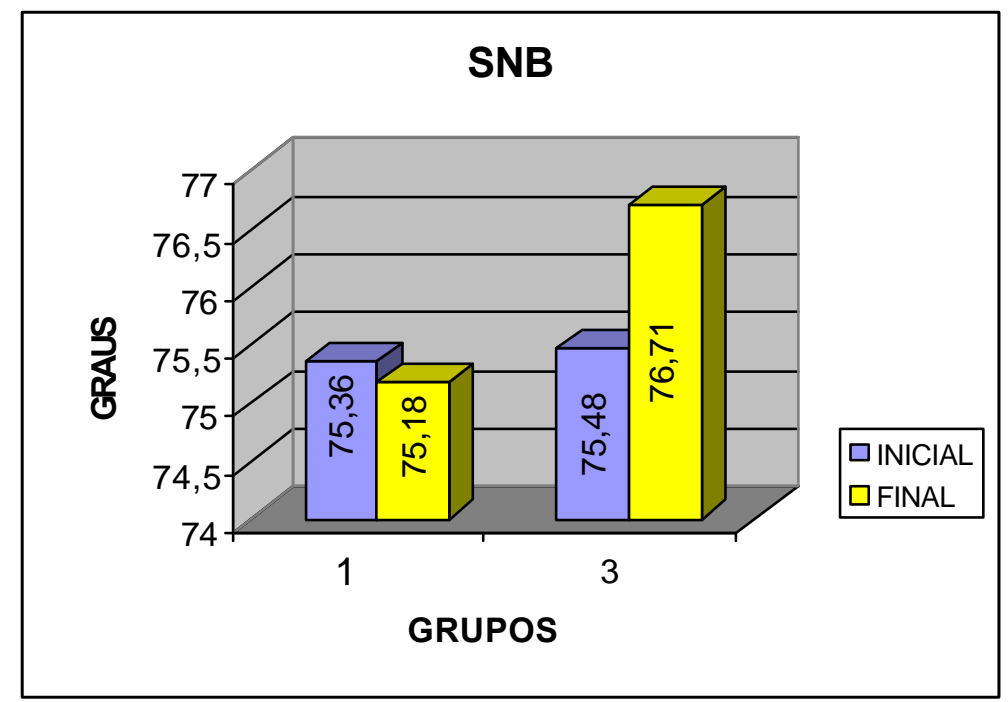

FIGURA 26- Valores médios iniciais e finais da grandeza SNB para os grupos 1 e 3. 


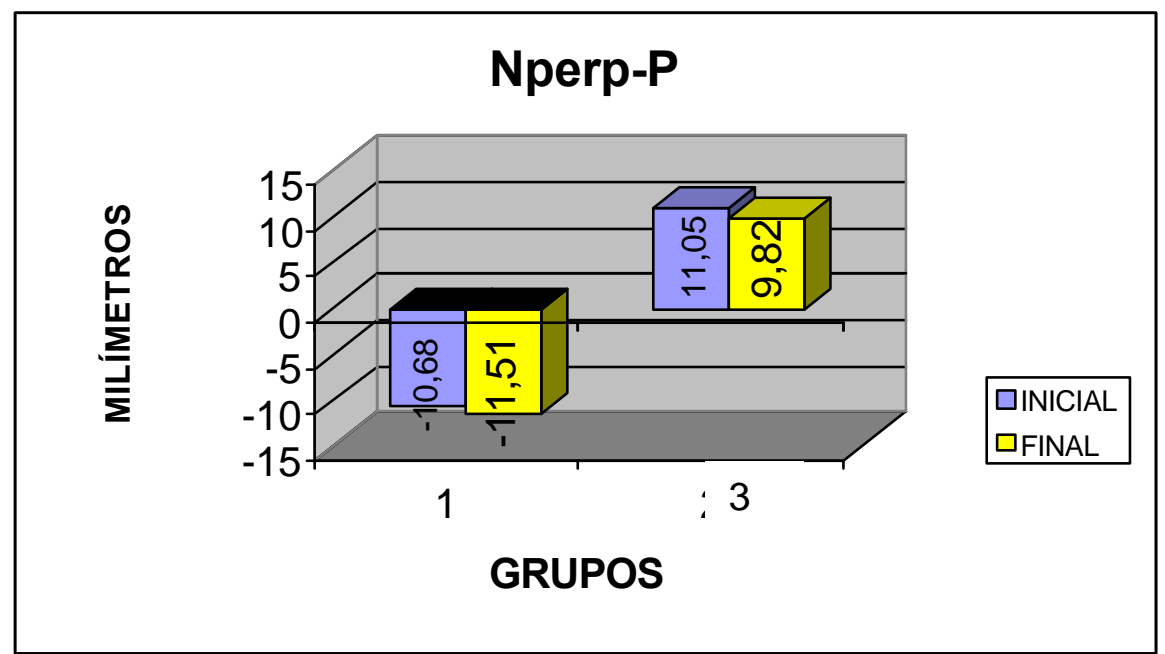

FIGURA 27- Valores médios iniciais e finais da grandeza Nperp-P para os grupos 1 e 3.

\subsubsection{3 - Grupo 2 X Grupo 3 (Tabela 11)}

Comparando-se os resultados dos grupos 2 e 3, ambos submetidos ao tratamento interceptativo, as grandezas que avaliam a protrusão mandibular (SNB e Nperp-P) demonstraram um maior aumento no grupo 3 (Figuras 28 e 29), considerado estatisticamente significante apenas para o ângulo SNB. 


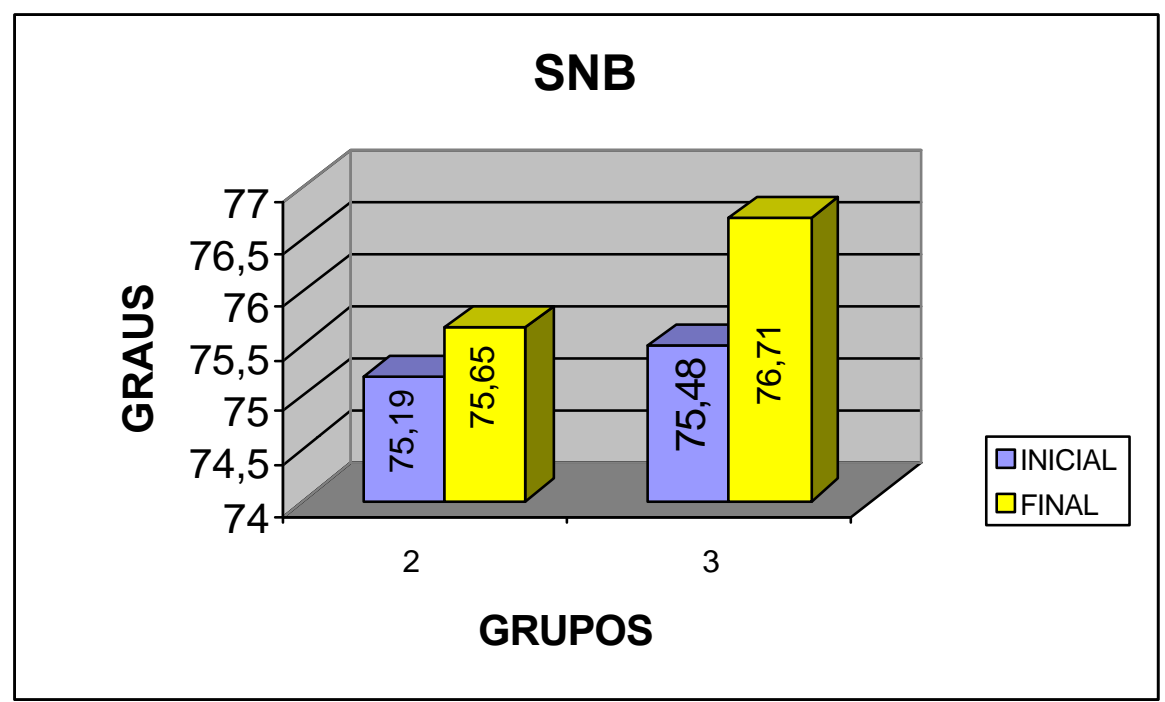

FIGURA 28- Valores médios iniciais e finais da grandeza SNB para os grupos 2 e 3.

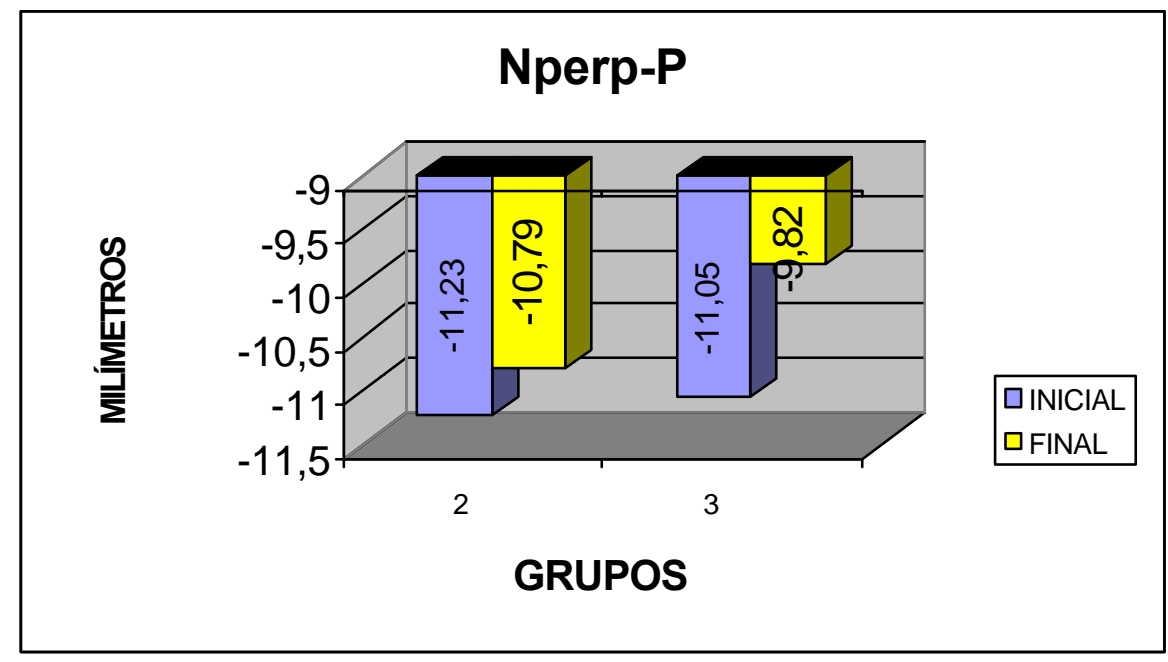

FIGURA 29- Valores médios iniciais e finais da grandeza Nperp-P para os grupos 2 e 3 . 


\subsection{2. - Comparação das alterações na relação maxilomandibular.}

O relacionamento entre a maxila e a mandíbula melhorou significantemente com a diminuição dos ângulos ANB e NAP principalmente nos grupos tratados (Tabelas 9, 10 e 11).

\subsubsection{1 - Grupo 1 X Grupo 2 (Tabela 9)}

Verificou-se uma melhora do relacionamento maxilomandibular em ambos os grupos 1 e 2, representada por uma diminuição do valor da grandeza cefalométrica ANB (Figura 30). Entretanto, o grupo 2 mostrou uma redução desse valor significantemente maior que o grupo 1 e conseqüentemente uma maior suavização da discrepância entre as bases ósseas.

A convexidade óssea analisada pela medida NAP (Figura 31) denotou uma melhora em ambos os grupos com redução significantemente maior no grupo 2 .

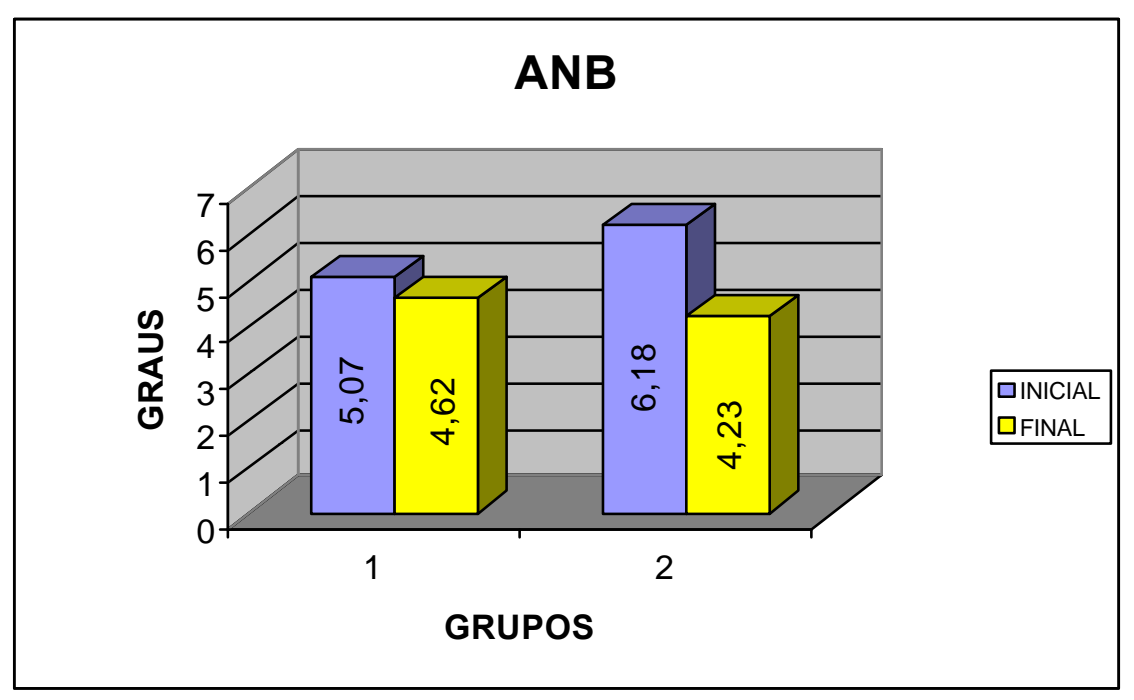

FIGURA 30- Valores médios iniciais e finais da grandeza ANB para os grupos 1 e 2 . 


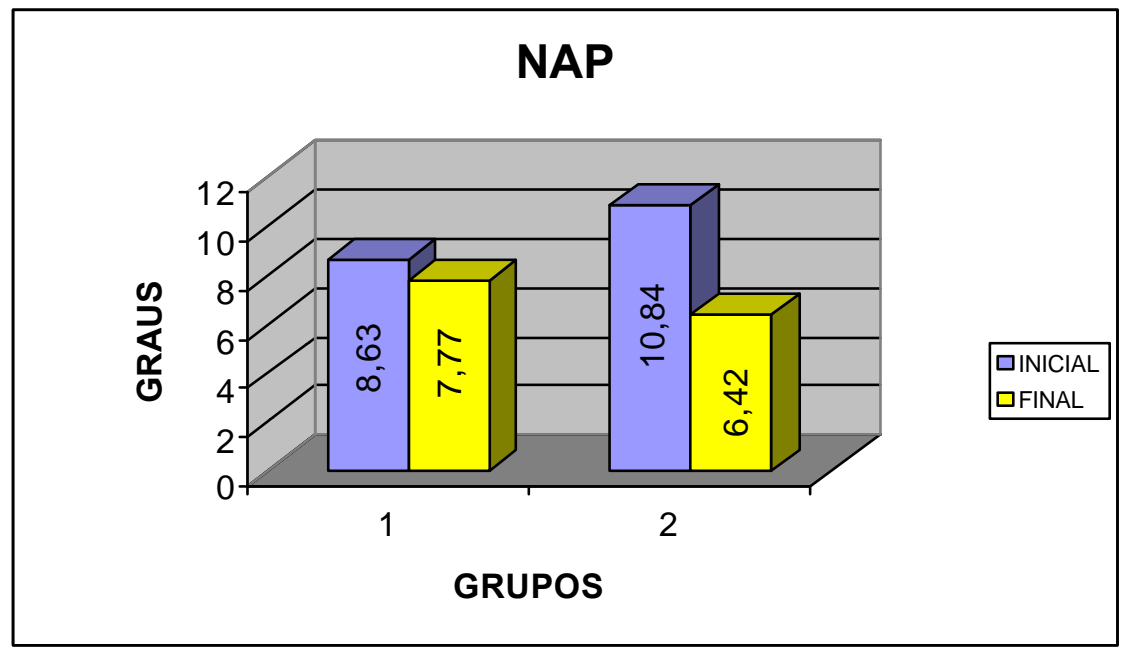

FIGURA 31- Valores médios iniciais e finais da grandeza NAP para os grupos 1 e 2.

\subsubsection{2 - Grupo 1 X Grupo 3 (Tabela 10)}

O grupo sob tratamento com o Bionator de Balters (grupo 3) proporcionou uma melhora da relação esquelética de Classe II, comparando-se com o grupo controle, uma vez que a redução do ANB no grupo 3 (Figura 32), foi significantemente mais expressiva $(p<0,01)$.

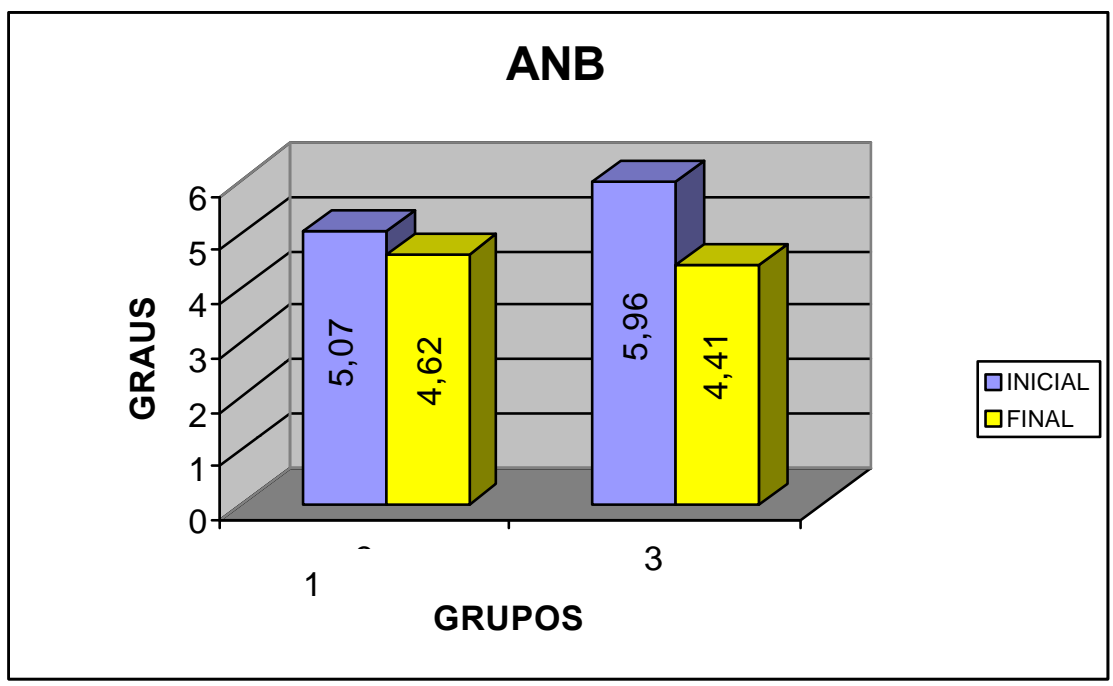

FIGURA 32- Valores médios iniciais e finais da grandeza ANB para os grupos 1 e 3. 
A grandeza NAP (Figura 33) também demonstrou uma redução da convexidade em ambos os grupos, sendo maior no grupo 3 atingindo uma diferença estatisticamente significante entre os grupos $(p<0,01)$.

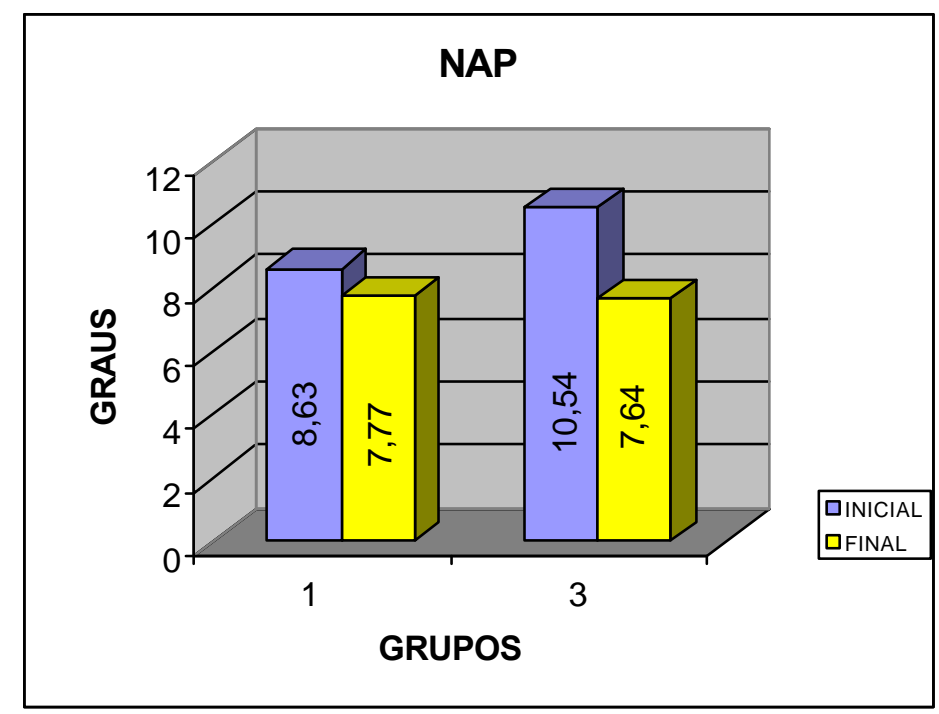

FIGURA 33- Valores médios iniciais e finais da grandeza NAP para os grupos 1 e 3.

\subsubsection{3 - Grupo 2 X Grupo 3 (Tabela 11)}

Em ambos os grupos tratados, o valor do ângulo ANB diminuiu (Figura 34), evidenciando que os aparelhos promoveram uma correção da discrepância óssea maxilomandibular. Não se verificou diferença significante entre os grupos 2 e 3. 


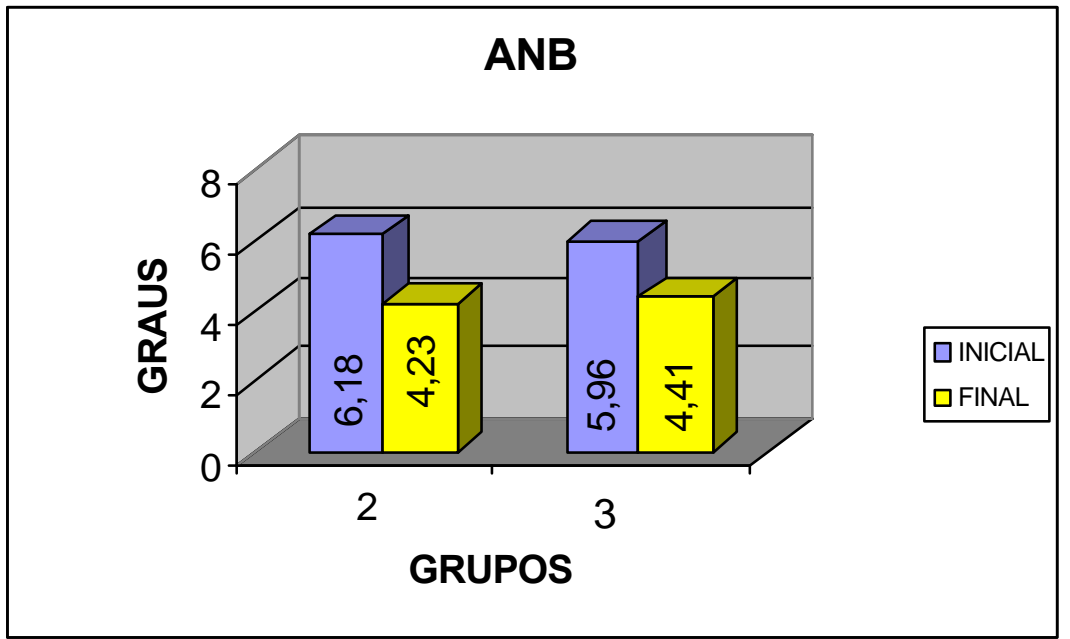

FIGURA 34- Valores médios iniciais e finais da grandeza ANB para os grupos 2 e 3.

O ângulo NAP (Figura 35) também mostrou semelhança com o ANB, denotando uma melhora em ambos os grupos, porém sem diferença estatisticamente significante.

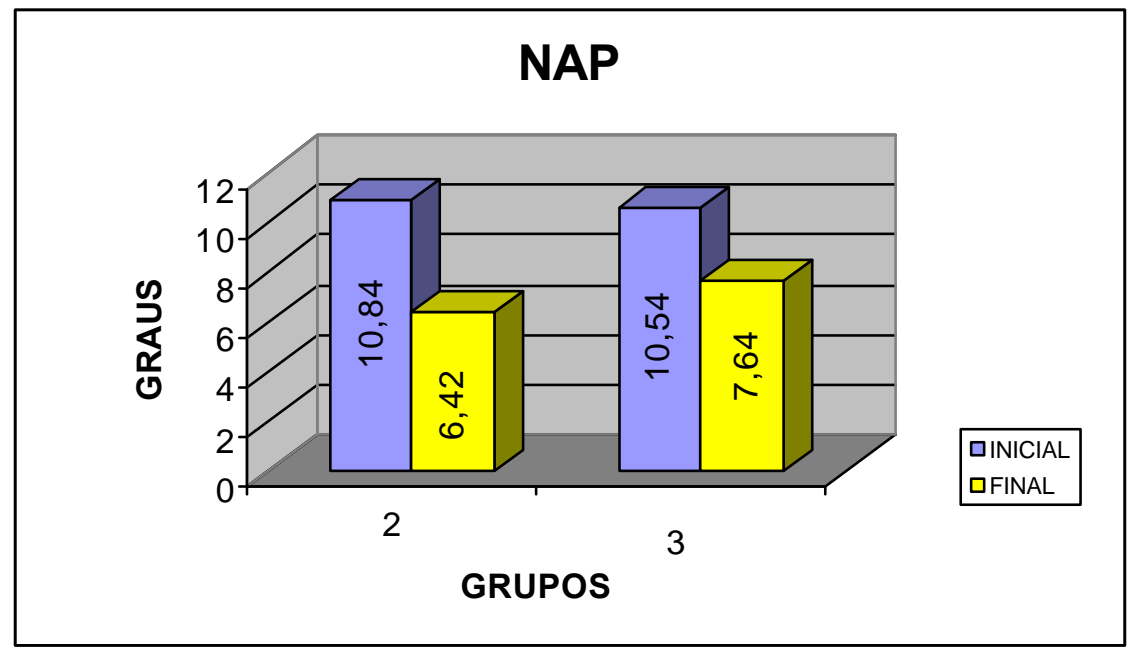

FIGURA 35- Valores médios iniciais e finais da grandeza NAP para os grupos 2 e 3. 


\subsection{4. - Comparação das alterações nos componentes dentoalveolares.}

Com exceção da medida $\underline{6}-\mathrm{PP}$, todas as variáveis dentárias superiores e inferiores apresentaram diferenças estatísticas. Assim, as grandezas cefalométricas 1.NA, 1-NA, $\underline{6}-\mathrm{FHp}, \overline{1} . \mathrm{NB}, \overline{1}-\mathrm{NB}, \overline{6}-\mathrm{FHp}, \overline{6}$-GoMe e IMPA foram submetidas ao teste de Tukey confrontando os grupos entre si (Tabelas 9, 10 e 11).

5.3.4.1. - Comparação das alterações dos dentes superiores em relação à maxila (1.NA, $\underline{1-N A}$ e $\underline{6}-\mathrm{FHp})$.

\subsubsection{1. - Grupo 1 X Grupo 2 (Tabela 9)}

Comparando-se os resultados do grupo controle com os do tratado com o AEB conjugado em relação ao posicionamento dos incisivos superiores, observourse um comportamento distinto entre eles. Enquanto o grupo 1 experimentou uma vestibularização e protrusão, o grupo 2 mostrou que os incisivos inclinaram-se para lingual e retruíram na base óssea (Figuras 36 e 37) sendo esta diferença estatisticamente significante ao nível de $1 \%$.

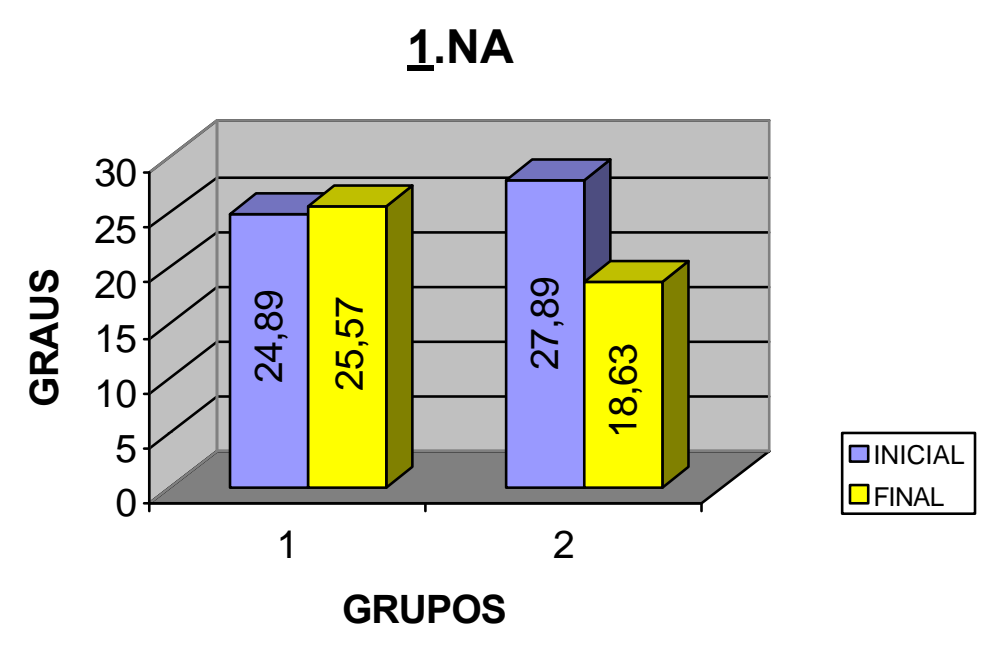

FIGURA 36- Valores médios iniciais e finais da grandeza 1.NA para os grupos 1 e 2. 


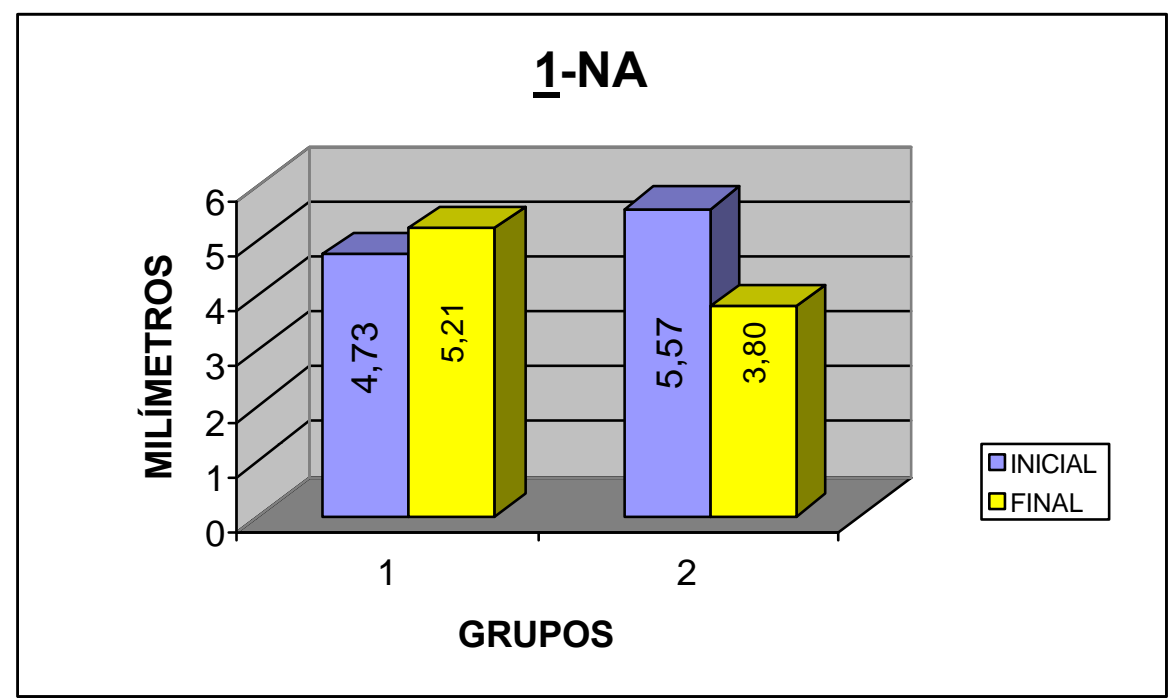

FIGURA 37- Valores médios iniciais e finais da grandeza 1-NA para os grupos 1 e 2.

Em relação ao posicionamento horizontal dos primeiros molares superiores avaliado pela grandeza $\underline{6}-\mathrm{FHp}$ verificou-se uma distalização estatisticamente significante $(1 \%)$ destes dentes no grupo tratado com o AEB conjugado comparando com o grupo controle que experimentou uma mesialização (Figura 38).

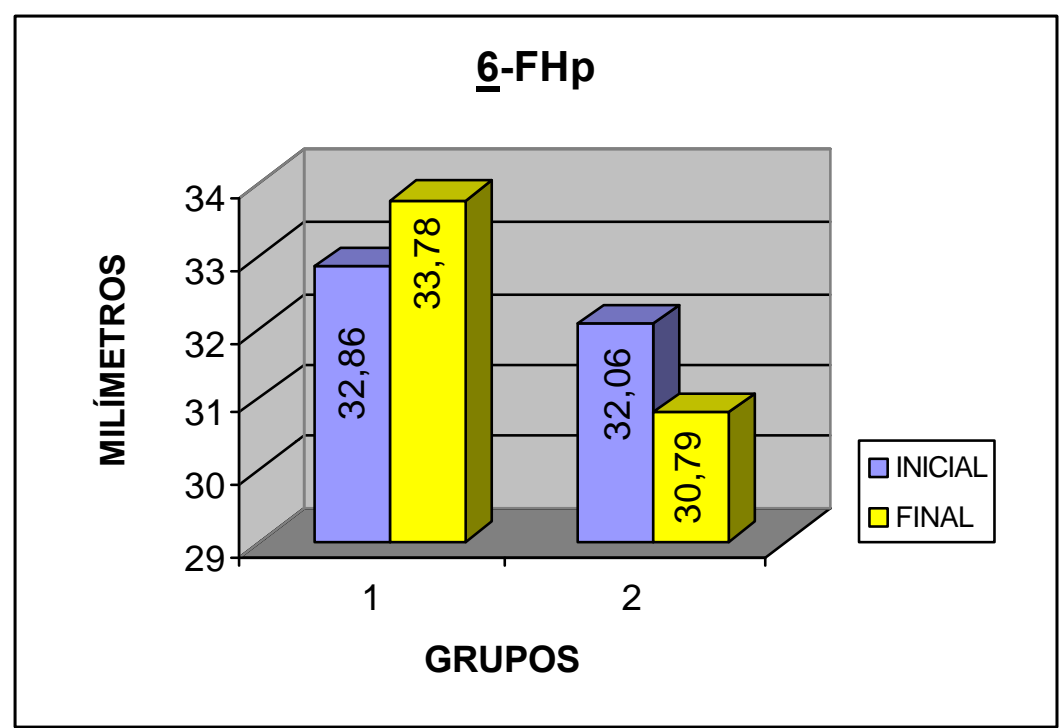

FIGURA 38-Valores médios iniciais e finais da grandeza $\underline{6}-\mathrm{FHp}$ para os grupos 1 e 2 . 


\subsubsection{2. - Grupo 1 X Grupo 3 (Tabela 10)}

As grandezas cefalométricas 1.NA e 1-NA (Figuras 39 e 40) mostraram resultados distintos, sendo que no grupo 1 evidenciou-se uma vestibularização e protrusão dos incisivos enquanto no grupo tratado com o Bionator notourse uma inclinação para lingual e retrusão desses dentes com diferença estatisticamente significante entre os grupos.

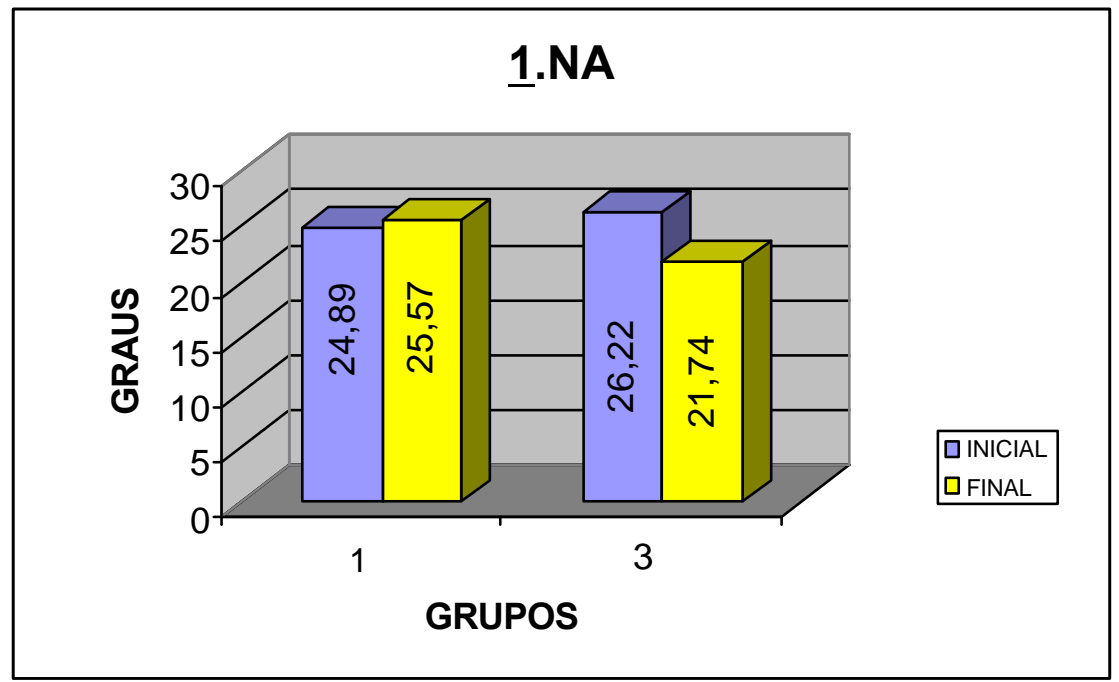

FIGURA 39- Valores médios iniciais e finais da grandeza 1.NA para os grupos 1 e 3.

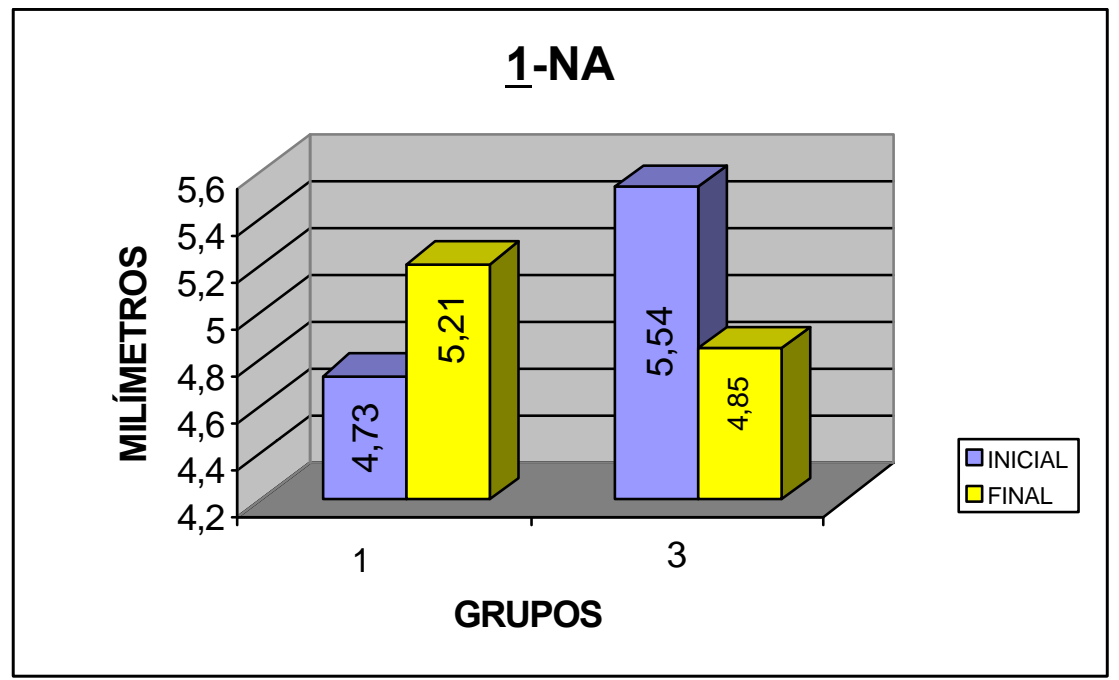

FIGURA 40- Valores médios iniciais e finais da grandeza 1-NA para os grupos 1 e 3. 
Quanto ao deslocamento ântero-posterior dos primeiros molares superiores, não se observou comportamento distinto entre o grupo tratado com o Bionator e o controle. Ambos os grupos apresentaram suave mesialização destes dentes (Figura 41).

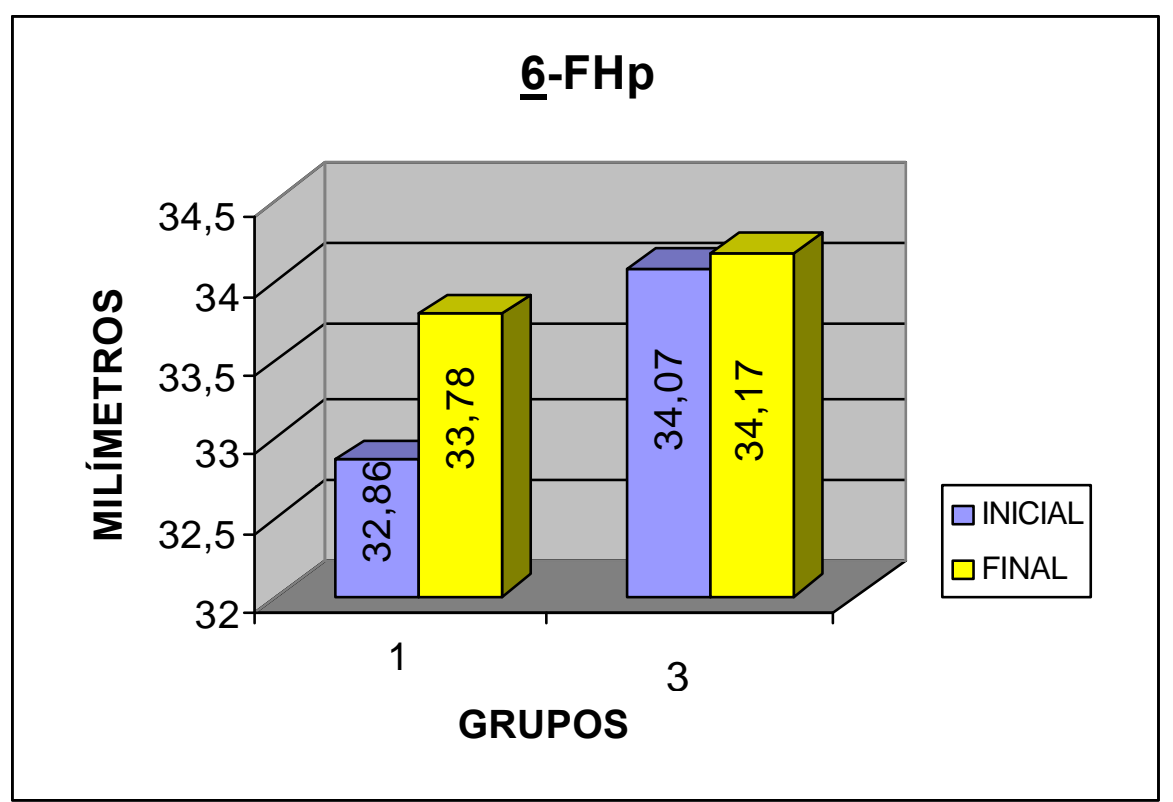

FIGURA 41-Valores médios iniciais e finais da grandeza 6 -FHp para os grupos 1 e 3. 
5.3.4.1.3. - Grupo 2 X Grupo 3 (Tabela 11)

Os resultados apontados pelas grandezas 1 .NA e 1-NA aludiram semelhança em ambos os grupos tratados (Figuras 42 e 43), sendo que no grupo 2 observourse uma maior lingualização e retrusão dos incisivos comparado ao grupo 3, apresentando diferença estatisticamente significante.

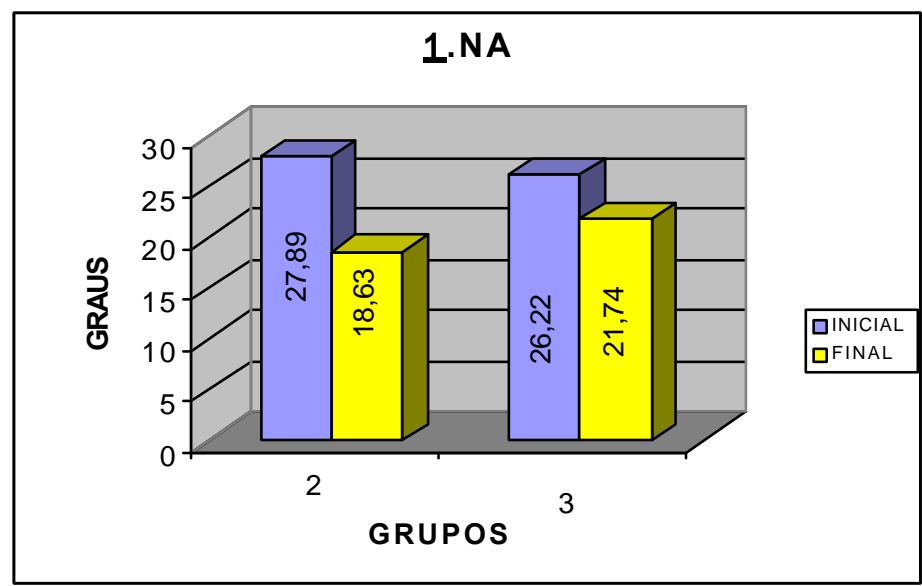

FIGURA 42- Valores médios iniciais e finais da grandeza 1.NA para os grupos 2 e 3.

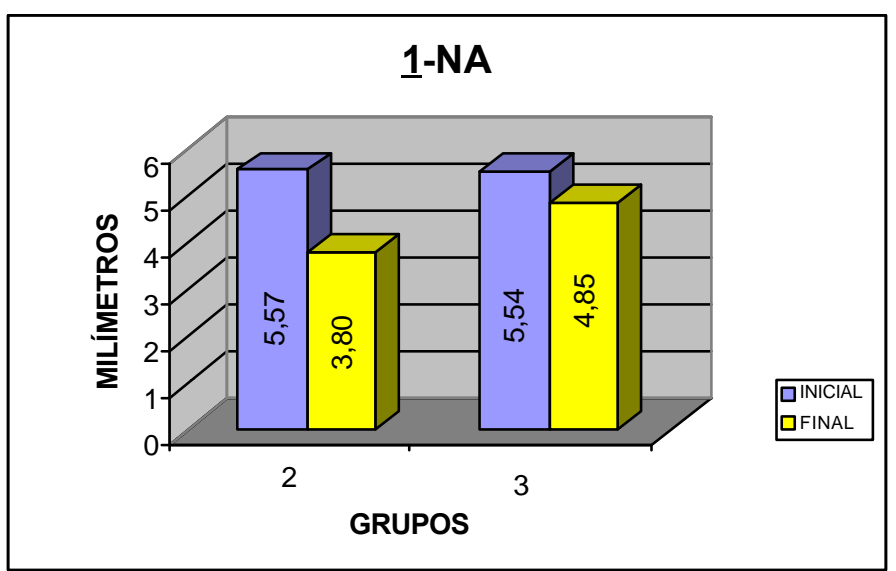

FIGURA 43- Valores médios iniciais e finais da grandeza 1-NA para os grupos 2 e 3. 
Comparando os grupos tratados em relação ao posicionamento horizontal dos molares superiores verificou-se um comportamento distinto. Enquanto o grupo 2 apresentou distalização o grupo 3 experimentou uma discreta mesialização destes dentes (Figura 44). No entanto, esta diferença entre os grupos não alcançou significância estatística.

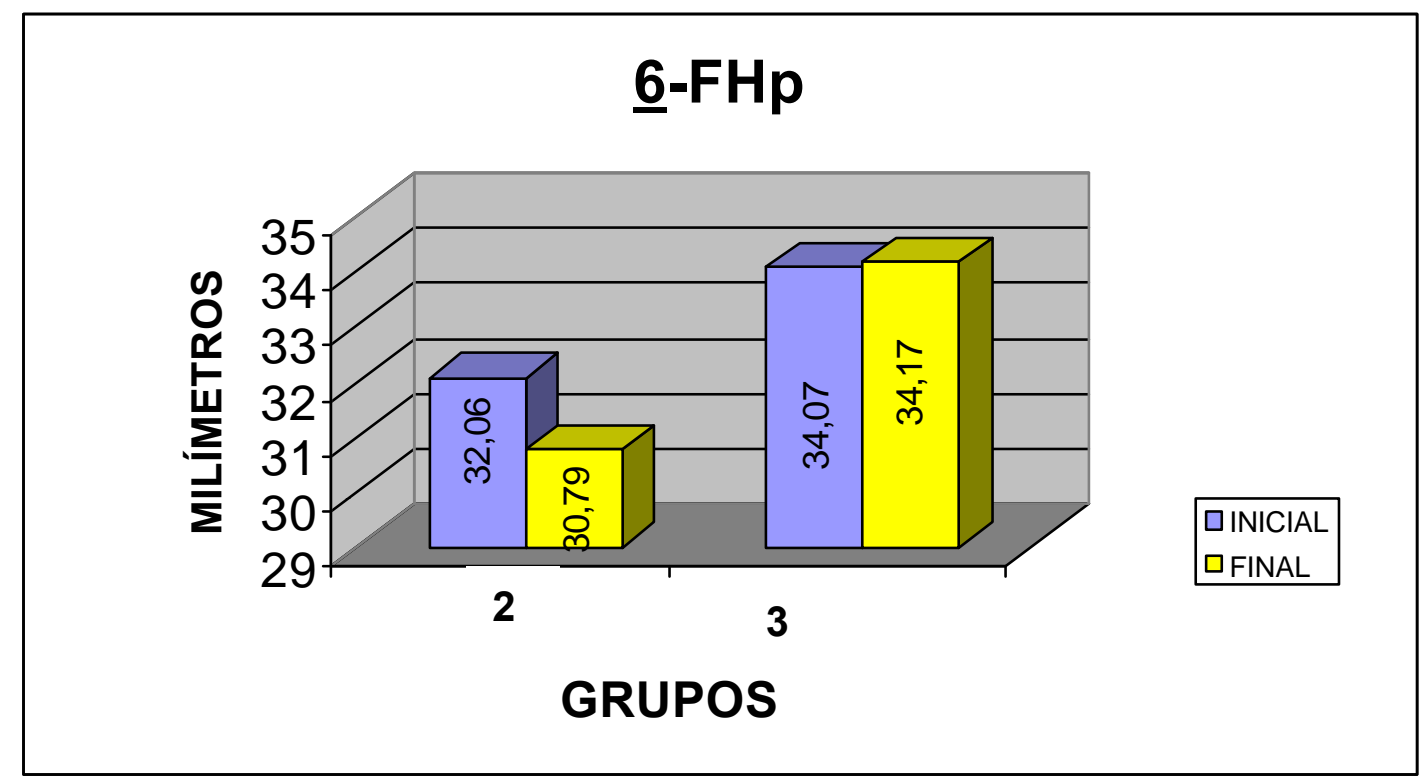

FIGURA 44-Valores médios iniciais e finais da grandeza $\underline{6}-\mathrm{FHp}$ para os grupos 2 e 3. 
5.3.4.2. - Comparação das alterações dos dentes inferiores em relação à mandíbula ( $\overline{1}$.NB, $\overline{1}-\mathrm{NB}, \overline{6}-\mathrm{FHp}, \overline{6}$-GoMe e IMPA).

\subsubsection{1. - Grupo 1 X Grupo 2 (Tabela 9)}

Em relação aos incisivos inferiores, as grandezas angulares (1.NB e IMPA) demonstraram comportamentos distintos e estatisticamente significante entre os dois grupos. No grupo controle os incisivos inclinaram-se para vestibular, enquanto no grupo tratado verificou-se uma inclinação para lingual destes dentes (Figuras 45 e 46).

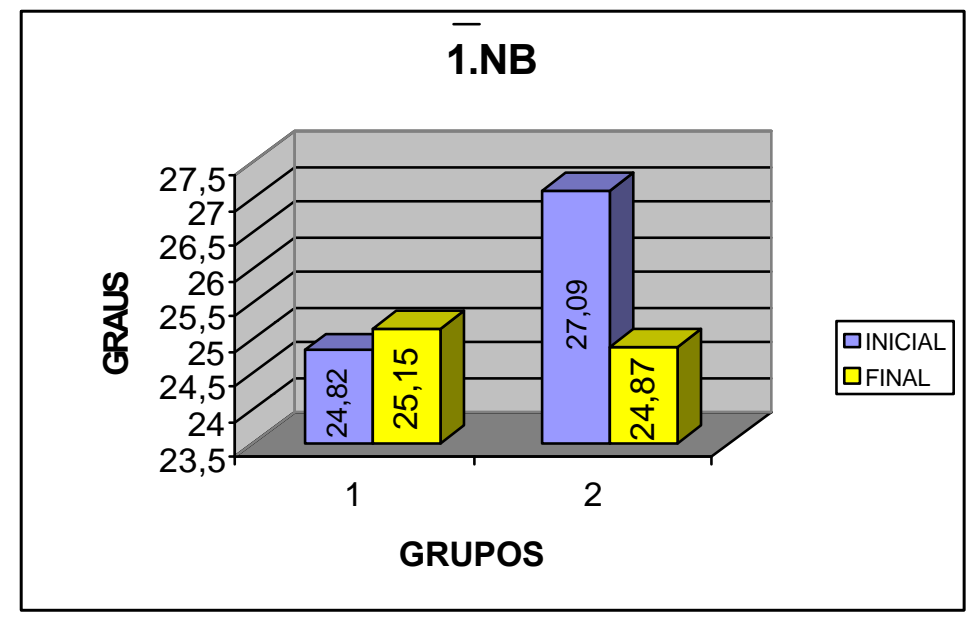

FIGURA 45- Valores médios iniciais e finais da grandeza $\overline{1}$.NB para os grupos 1 e 2. 


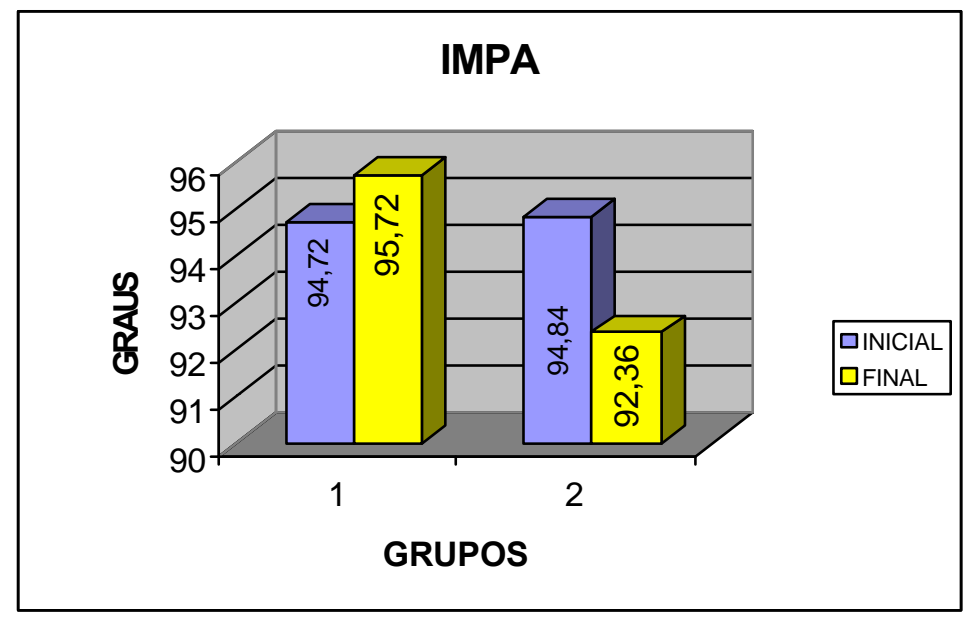

FIGURA 46- Valores médios iniciais e finais da grandeza IMPA para os grupos 1 e 2.

\subsubsection{2. - Grupo 1 X Grupo 3 (Tabela 10)}

No grupo 1 evidenciourse pouca alteração na inclinação vestibulolingual, enquanto no grupo 3 notourse maior vestibularização (Figuras 47 e 48), exibindo diferença estatisticamente significante entre os dois grupos ao nível de $1 \%$ apenas para o ângulo $\overline{1}$.NB.

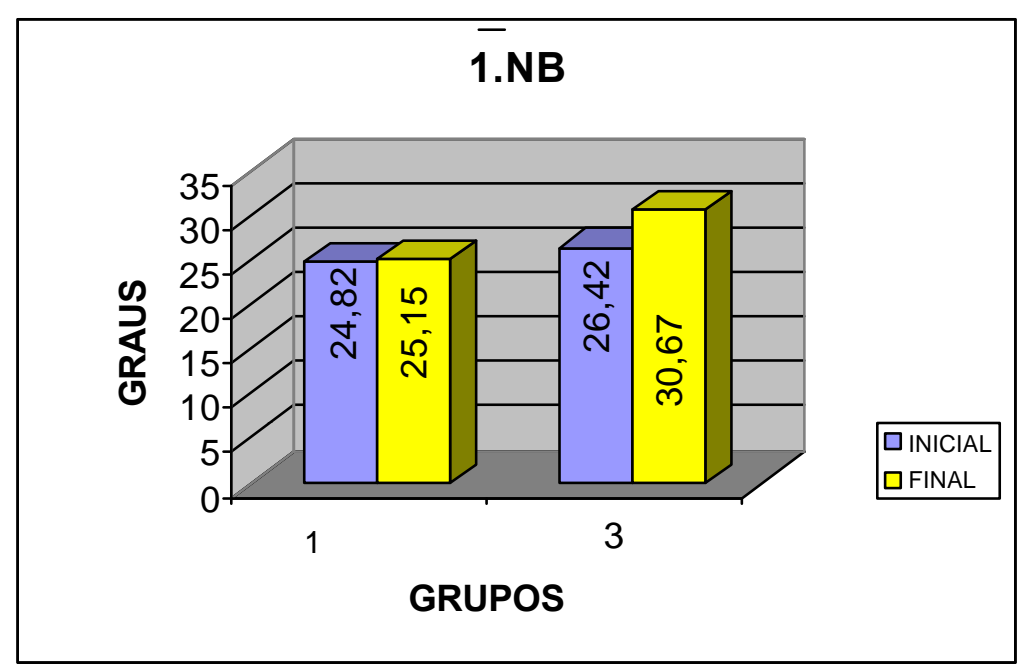

FIGURA 47- Valores médios iniciais e finais da grandeza 1.NB para os grupos 1 e 3. 


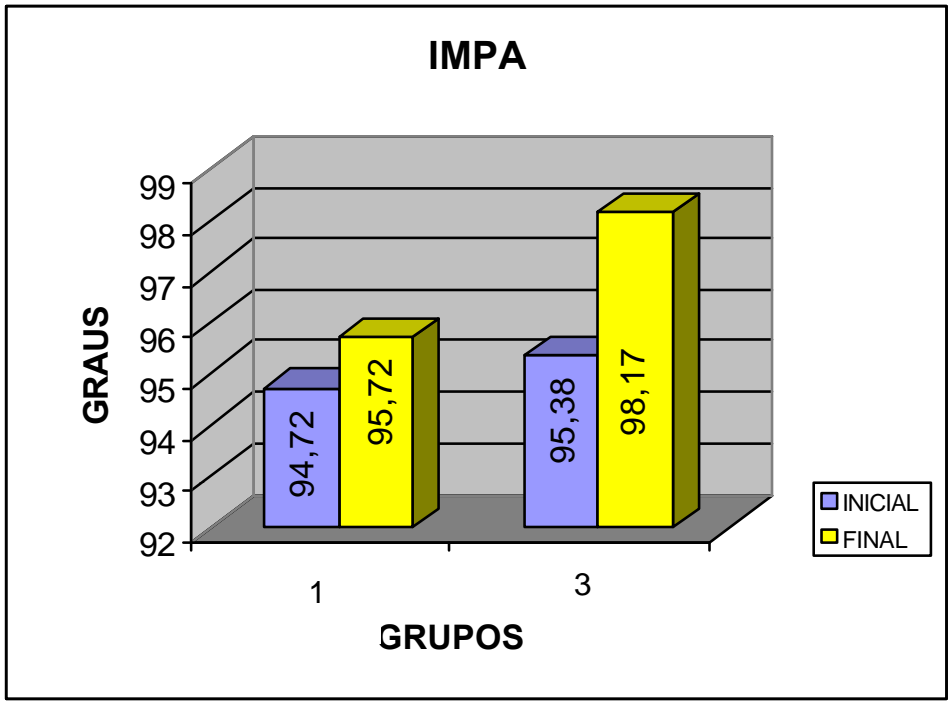

FIGURA 48- Valores médios iniciais e finais da grandeza IMPA para os grupos 1 e 3.

\subsubsection{3. - Grupo 2 X Grupo 3 (Tabela 11)}

Os grupos 2 e 3 demonstraram comportamentos distintos com diferenças significantes para os ângulos 1.NB e IMPA. No grupo tratado com o AEB conjugado os incisivos inclinaram para lingual, enquanto que no grupo 3 ocorreu o contrário (Figuras 49 e 50).

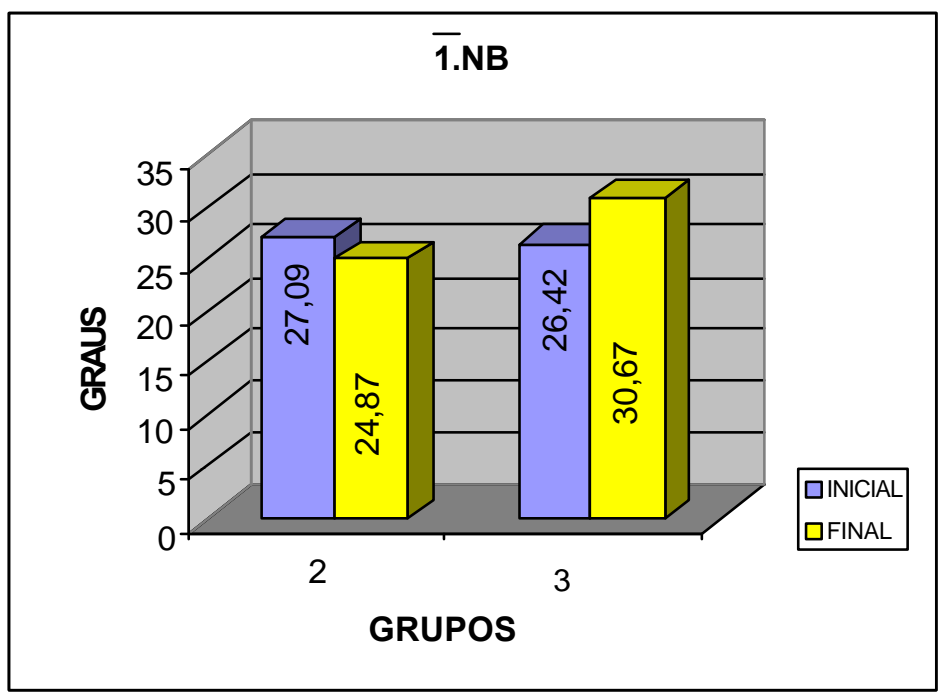

FIGURA 49- Valores médios iniciais e finais da grandeza $\overline{1}$.NB para os grupos 2 e 3. 


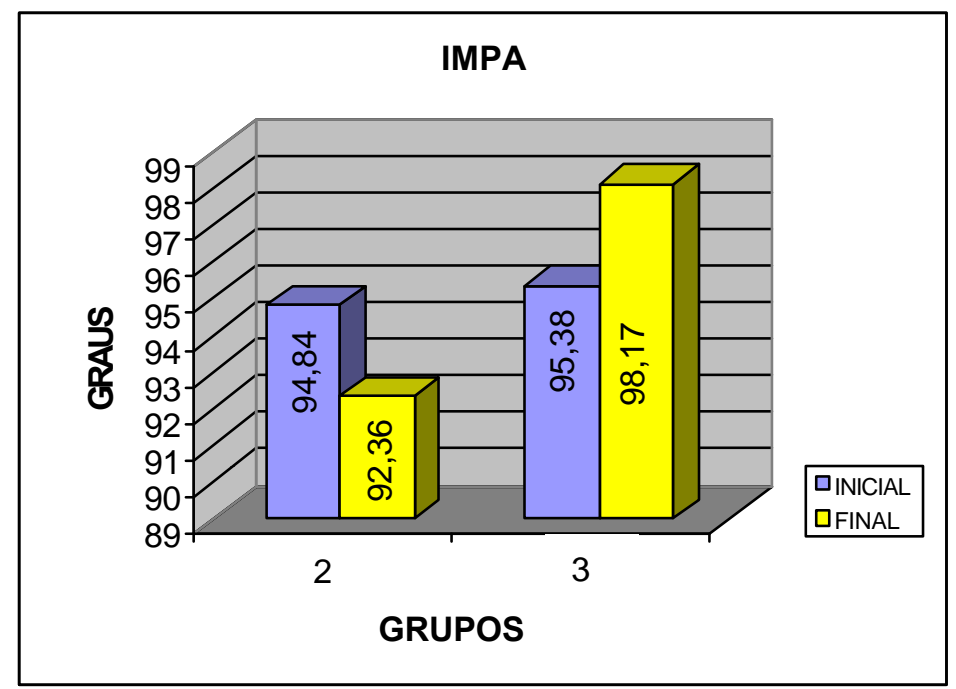

FIGURA 50- Valores médios iniciais e finais da grandeza IMPA para os grupos 2 e 3.

5.3.4.3. - Comparação das alterações lineares dos dentes inferiores em relação à mandíbula ( $\overline{1}-\mathrm{NB}, \overline{6}-\mathrm{FHp}$ e $\overline{6}$-GoMe).

\subsubsection{1. - Grupo 1 X Grupo 2 (Tabela 9)}

Avaliando-se a posição ântero-posterior dos incisivos inferiores por meio da grandeza 1-NB (Figura 51) para o grupo 1, notou-se uma protrusão destes, enquanto o grupo 2 mostrou uma retrusão, porém sem diferença significante.

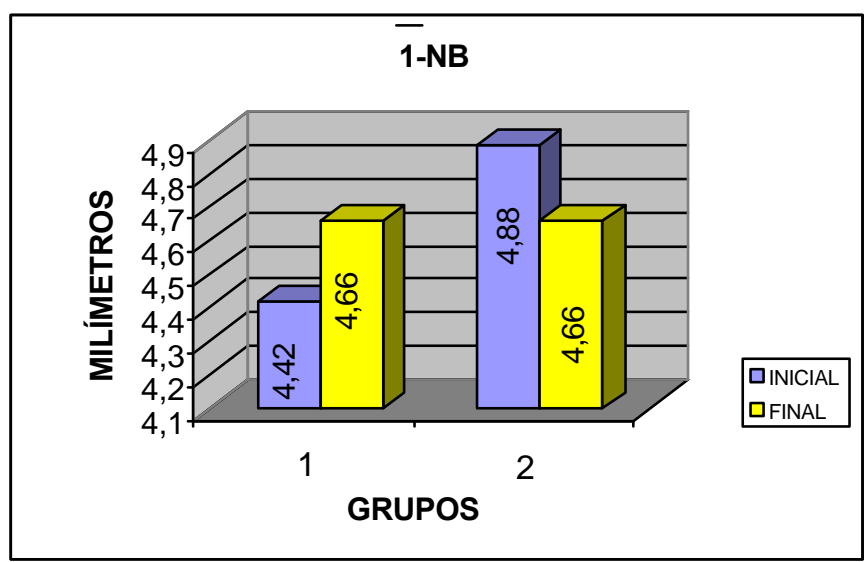

FIGURA 51- Valores médios iniciais e finais da grandeza 1-NB para os grupos 1 e 2. 
A posição dos primeiros molares inferiores no sentido ântero-posterior foi semelhante entre os grupos 1 e 2. Em ambos os grupos observoutse uma mesialização destes dentes porém no grupo tratado com o AEB conjugado este deslocamento foi mais intenso mostrando diferença estatisticamente significante ao nível de 1\% (Figura 52).

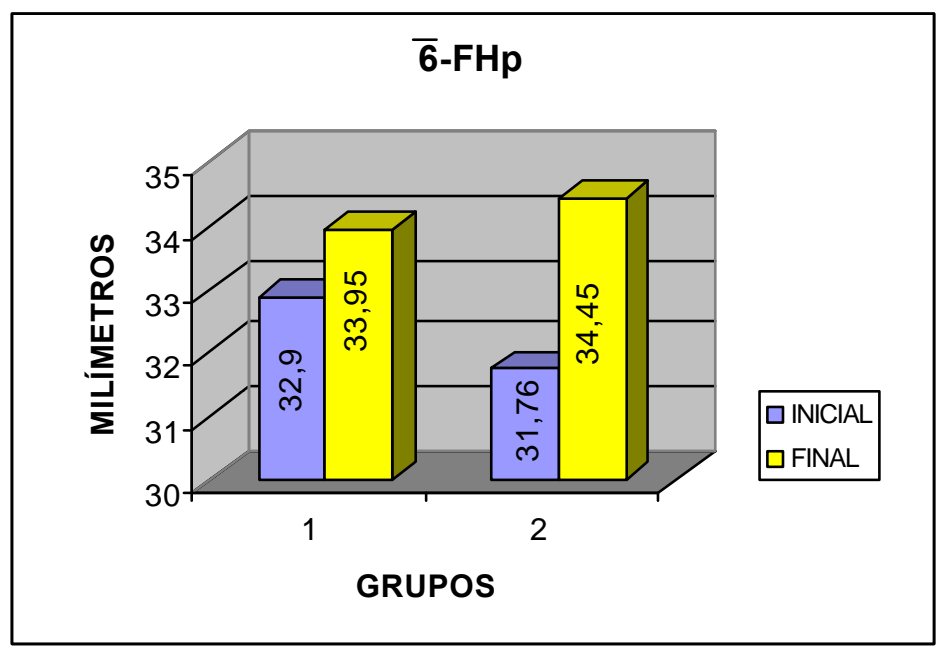

FIGURA 52- Valores médios iniciais e finais da grandeza $\overline{6}$-FHp para os grupos 1 e 2.

Em relação ao posicionamento vertical dos primeiros molares inferiores verificourse um aumentou para ambos os grupos (Figura 53), traduzido por uma extrusão destes dentes na má oclusão de Classe II, 1ํㅡㄹ divisão, quando submetida ou não ao tratamento. Compulsando os valores das alterações médias, constatourse que essa extrusão apresentou-se significantemente mais intensa no grupo 2 em comparação ao grupo 1, resultando em uma diferença estatística ao nível de 1\%.

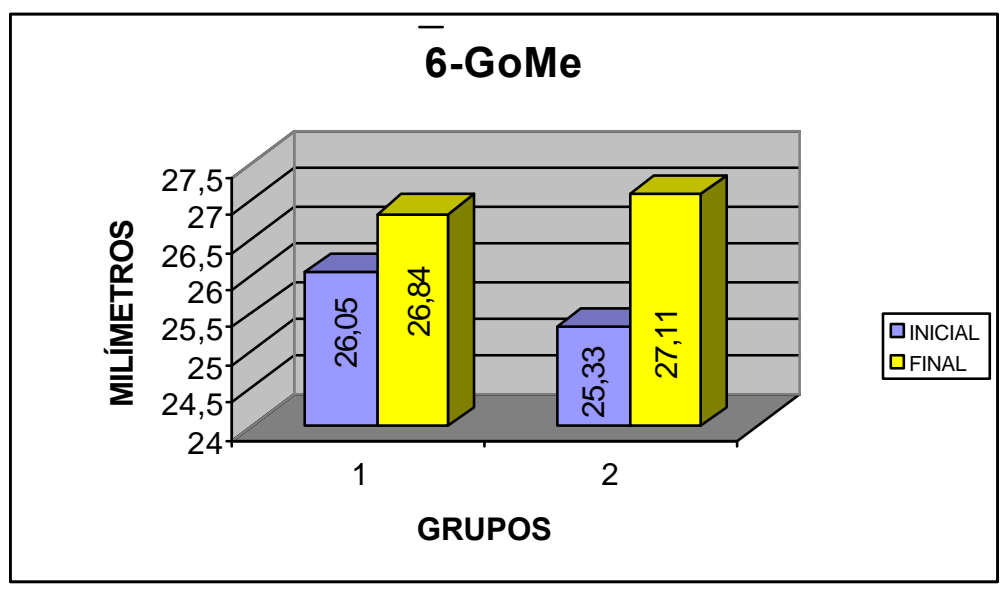

FIGURA 53- Valores médios iniciais e finais da grandeza $\overline{6}$-GoMe para os grupos 1 e 2. 


\subsubsection{2. - Grupo 1 X Grupo 3 (Tabela 10)}

A grandeza 1-NB (Figura 54), mostrou para o grupo 1, uma discreta protrusão dos incisivos, enquanto que no grupo 3 houve uma maior protrusão destes dentes, apresentando diferença significante ao nível de $1 \%$.

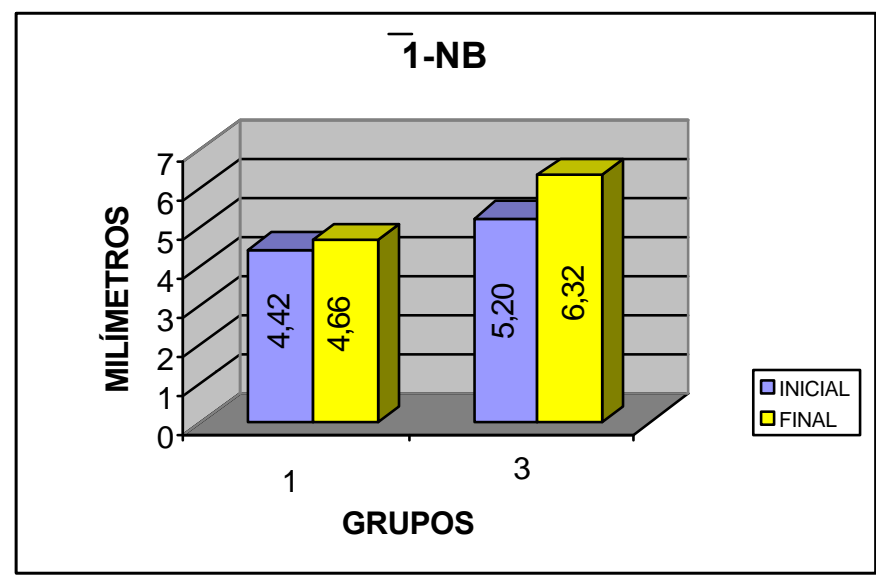

FIGURA 54- Valores médios iniciais e finais da grandeza 1-NB para os grupos 1 e 3.

Analisando o deslocamento horizontal dos primeiros molares inferiores pela medida $\overline{6}$-FHP observou-se um comportamento similar entre os grupos, demonstrando mesialização destes dentes. No entanto, foram verificadas diferenças estatisticamente significantes (1\%) entre o grupo tratado com o Bionator e o controle sendo que neste último a mesialização foi menor (Figura 55).

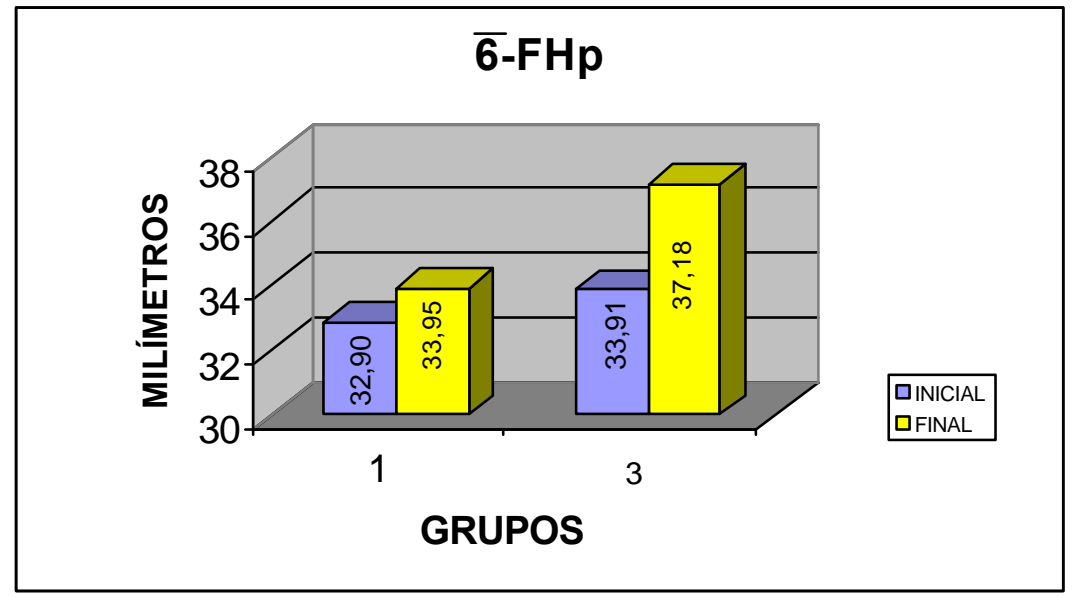

FIGURA 55- Valores médios iniciais e finais da grandeza $\overline{6}$-FHp para os grupos 1 e 3. 
Avaliando a extrusão dos molares inferiores em relação ao plano mandibular verificourse um comportamento similar entre os grupos. Nos dois grupos a grandeza linear $\overline{6}$-GoMe aumentou porém observourse um maior aumento significante estatisticamente no grupo tratado (Figura 56).

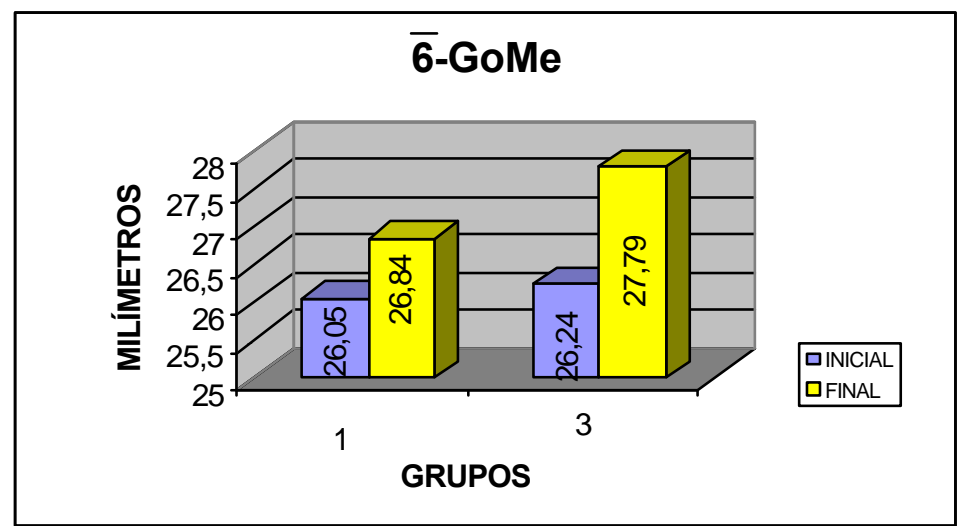

FIGURA 56- Valores médios iniciais e finais da grandeza $\overline{6}$-GoMe para os grupos 1 e 3.

\subsubsection{3. - Grupo 2 X Grupo 3 (Tabela 9)}

Os incisivos inferiores demonstraram comportamento distintos entre os grupos tratados avaliando a medida 1-NB (Figura 57). Enquanto que no grupo 2 os incisivos retruíram, no grupo tratado com o Bionator estes dentes experimentaram uma protrusão. Esta diferença entre os grupos foi estatisticamente significante.

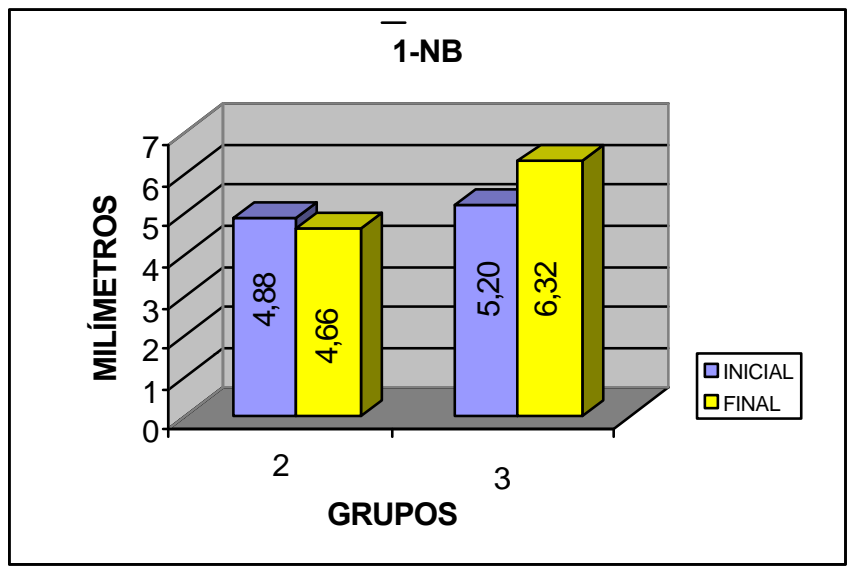

FIGURA 57- Valores médios iniciais e finais da grandeza 1-NB para os grupos 2 e 3. 
Em relação ao deslocamento dos primeiros molares inferiores, verificourse uma mesialização semelhante em ambos os grupos tratados, não apresentando diferença estatística significante (Figura 58).

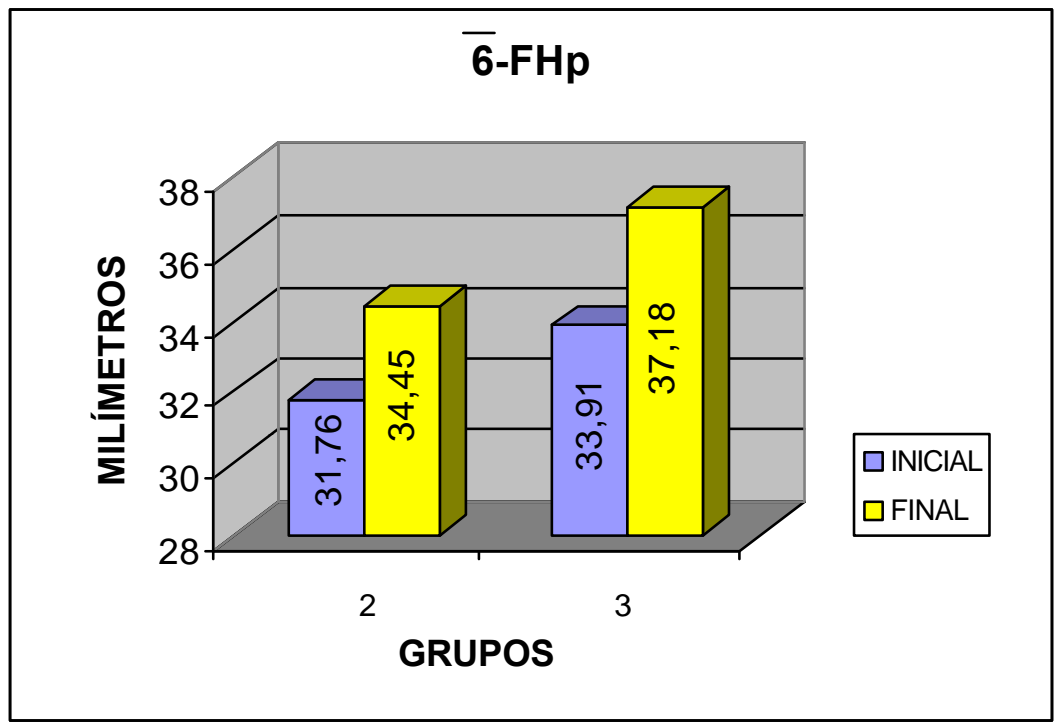

FIGURA 58- Valores médios iniciais e finais da grandeza $\overline{6}$-FHp para os grupos 2 e 3.

A quantidade de extrusão dos primeiros molares inferiores (Figura 59) foi semelhante comparando-se os grupos tratados com o AEB conjugado e o Bionator, sem denotar diferença estatística.

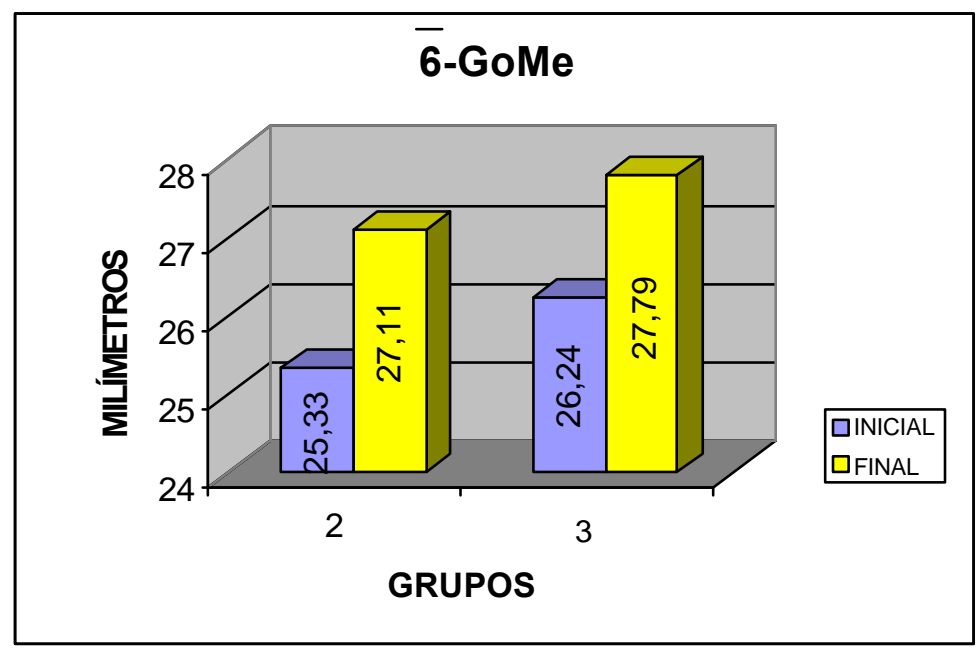

FIGURA 59- Valores médios iniciais e finais da grandeza $\overline{6}$-GoMe para os grupos 2 e 3. 


\subsection{4. - Comparação das alterações no perfil tegumentar.}

O posicionamento dos lábios superior e inferior em relação à linha Pog'Sn mostrou comportamentos distintos entre os grupos, denotando diferenças estatísticas (Tabelas 9, 10 e 11).

5.3.4.1. - Comparação das alterações no perfil tegumentar superior (Ls-Pog'Sn).

\subsubsection{1. - Grupo 1 X Grupo 2 (Tabela 9)}

A grandeza linear Ls-Pog'Sn (Figura 60) mostrou um comportamento inverso para os grupos 1 e 2 . No grupo controle evidenciou um discreto aumento dessa medida sugerindo uma protrusão do lábio superior, enquanto que para o grupo 2 notourse uma discreta retrusão do lábio, sendo que este comportamento diferiu estatisticamente.

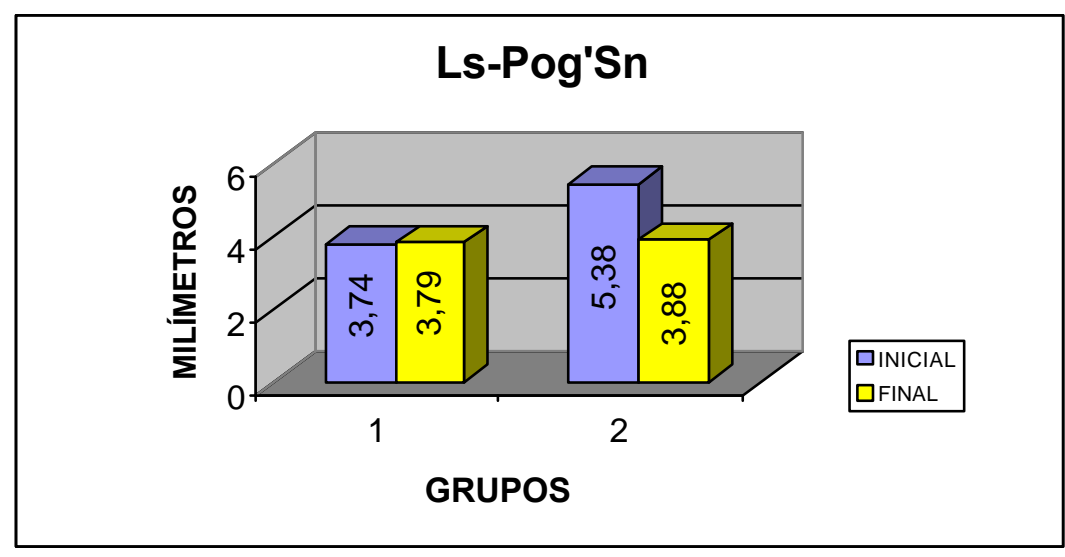

FIGURA 60- Valores médios iniciais e finais da grandeza Ls-Pog'Sn para os grupos 1 e 2 


\subsubsection{2. - Grupo 1 X Grupo 3 (Tabela 10)}

O mesmo comportamento inverso ocorreu para os grupos 1 e 3 (Figura 61), sendo que o grupo 1 experimentou uma protrusão e o grupo 3 uma retrusão do lábio superior alcançando diferença estatisticamente significante ao nível de $1 \%$.

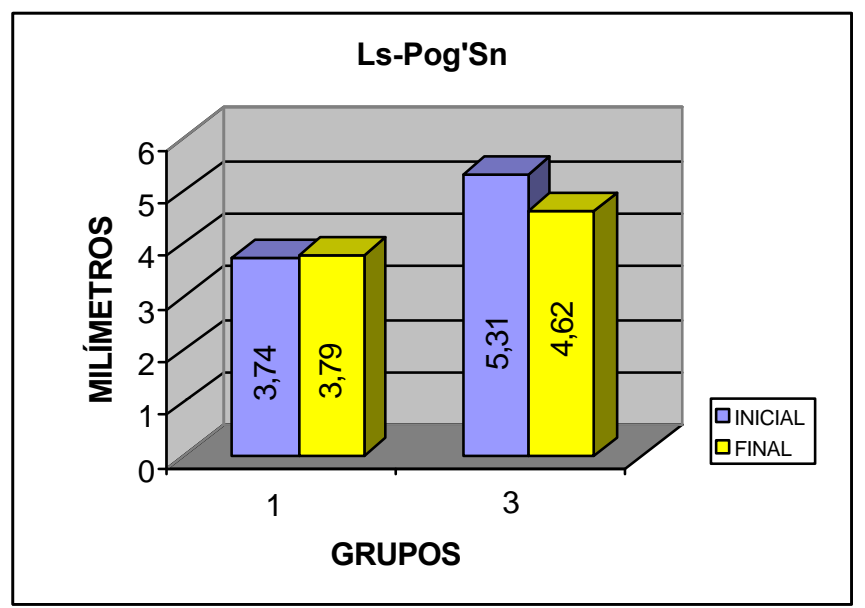

FIGURA 61- Valores médios iniciais e finais da grandeza Ls-Pog'Sn para os grupos 1 e 3.

\subsubsection{3. - Grupo 2 X Grupo 3 (Tabela 11)}

Ambos os grupos tratados experimentaram uma retrusão dos lábios superiores. No entanto, o grupo tratado com o AEB conjugado apresentou maior retrusão labial (Figura 62) com diferença estatística significante.

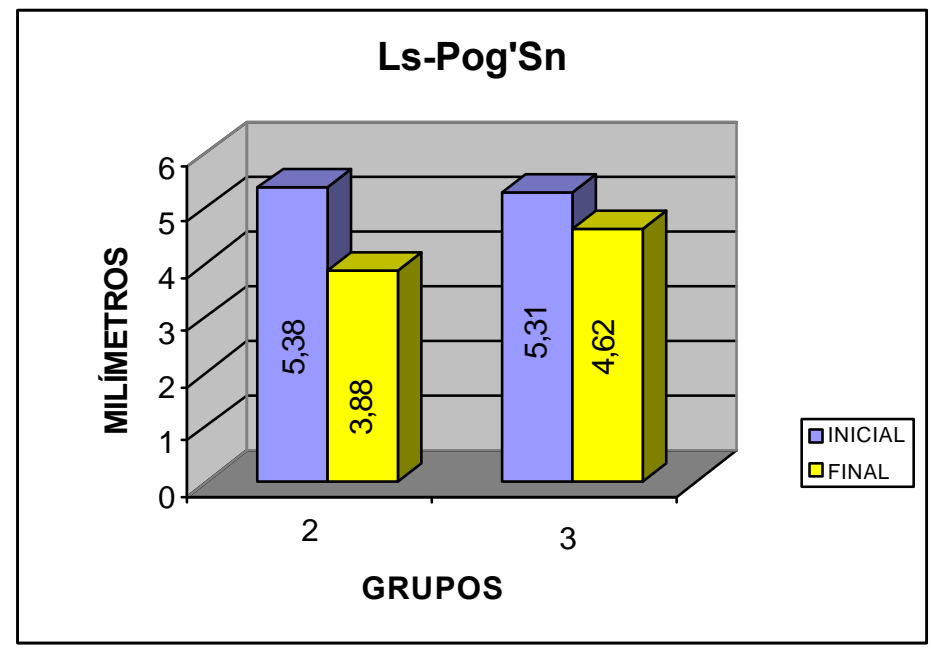

FIGURA 62- Valores médios iniciais e finais da grandeza Ls-Pog'Sn para os grupos 2 e 3. 
5.3.4.2. - Comparação das alterações no perfil tegumentar inferior (Li-Pog'Sn) .

\subsubsection{1. - Grupo 1 X Grupo 2 (Tabela 9)}

A grandeza linear Li-Pog'Sn (Figura 63) mostrou um comportamento inverso para os grupos 1 e 2 . No grupo controle evidenciou um discreto aumento dessa medida sugerindo uma protrusão do lábio inferior, enquanto que para o grupo 2 notourse uma retrusão do lábio, sendo que este comportamento diferiu estatisticamente.

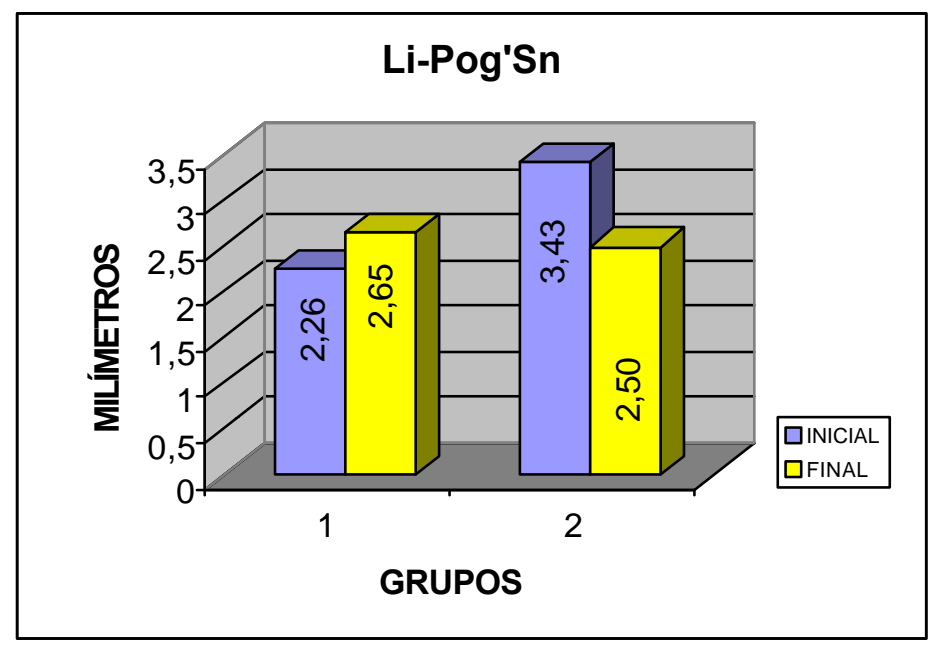

FIGURA 63- Valores médios iniciais e finais da grandeza Li-Pog'Sn para os grupos 1 e 2.

\subsubsection{2. - Grupo 1 X Grupo 3 (Tabela 10)}

Evidenciou-se uma similaridade nos resultados avaliados pela medida LiPog'Sn (Figura 64) com os grupos apresentando uma discreta protrusão dos lábios inferiores sem diferença estatística. 


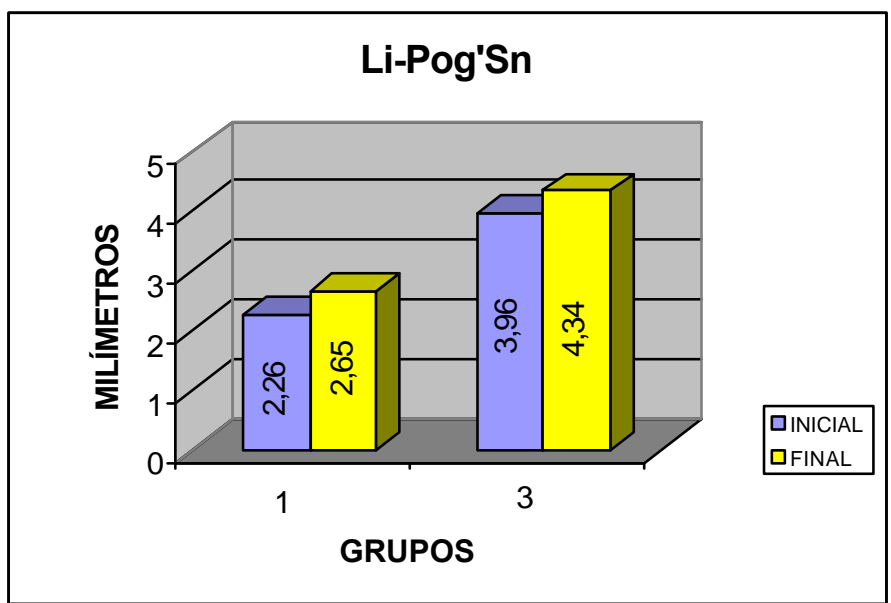

FIGURA 64- Valores médios iniciais e finais da grandeza Li-Pog'Sn para os grupos 1 e 3.

5.3.4.2.3. - Grupo 2 X Grupo 3 (Tabela 11)

Observou-se um comportamento inverso para os grupos 2 e 3 (Figura 65), sendo que o grupo 2 experimentou uma retrusão e o grupo 3 uma protrusão do lábio inferior alcançando diferença estatisticamente significante ao nível de $1 \%$.

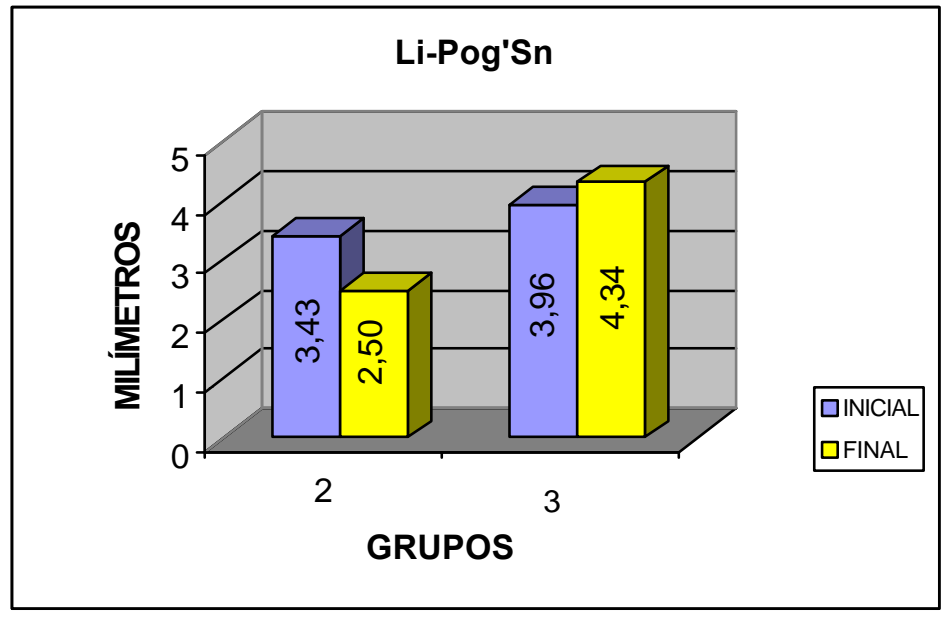

FIGURA 65- Valores médios iniciais e finais da grandeza Li-Pog'Sn para os grupos 2 e 3. 


\section{DISCUSSÃO}




\section{DISCUSSÃO}

Este capítulo está dividido em quatro tópicos distintos, visando o esclarecimento acerca da confiabilidade da metodologia empregada e dos resultados obtidos. Assim, primeiramente será apresentado o erro metodológico e em seguida a discussão quanto às características dos distintos grupos. Por fim, serão discutidos os resultados verificados nas comparações entre os grupos e realizadas as considerações finais.

\subsection{ERRO DO MÉTODO (TABELA 3)}

O estudo radiográfico cefalométrico, apresenta-se como um inestimável recurso para o diagnóstico, planejamento e acompanhamento ortodôntico. No entanto, para a utilização destas radiografias em pesquisas científicas, torna-se necessária a determinação do erro proveniente dos procedimentos envolvidos no traçado cefalométrico e na demarcação e digitalização dos pontos.

Os erros metodológicos são classificados em dois tipos: erro sistemático e casual. Para determiná-los HOUSTON ${ }^{74}$ sugeriu a duplicação dos cefalogramas em intervalos de tempo diferentes. Assim, de acordo com BAUMRIND; FRANTZ21 ${ }^{21}$, foram selecionadas ao acaso 20 telerradiografias provenientes dos 3 grupos estudados. Todas as radiografias foram traçadas e digitalizadas novamente pelo mesmo pesquisador, num intervalo de tempo de 4 semanas do traçado inicial, segundo recomendações de MIDTGARD; BJÖRK; LINDER-ARONSON ${ }^{110}$.

Para a verificação da significância estatística do erro sistemático utilizou-se o teste $\mathrm{t}$ de Student, ao nível de $1 \%$ e $5 \%$, e para o erro casual a fórmula de DAHLBERG ${ }^{42}$.

Para a interpretação do erro casual, baseando-se nas pesquisas de SANDLER $^{138}$ e de LIU; GRAVELLY ${ }^{95}$ considerou-se os valores do índice de DAHLBERG $^{42}$ acima de 1,5 graus e de 1 milímetro como erros significantes. 
Dentre as 25 medidas avaliadas observou-se que apenas uma variável ( $\overline{6}$-GoMe) apresentou um erro sistemático, ao nível de significância de 5\% e nenhuma demonstrou erro casual. No entanto, os erros provenientes de medidas dentárias estão previstos no envelope de erros sugerido por BAUMRIND; FRANTZ ${ }^{21}$.

Avaliando-se o erro casual do método, não se observou um valor maior que 0,93 para as medidas angulares ou 1,00 para as medidas lineares, demonstrando que a demarcação ou localização dos pontos, não interferiu na obtenção das grandezas cefalométricas, o que é freqüentemente observado nas pesquisas, como relatado por BAUMRIND; FRANTZ21, MIDTGARD; BJÖRK; LINDER-ARONSON ${ }^{110}$ e TRPKOVA et al. ${ }^{149}$

Diante destas observações pode-se considerar que os resultados do erro metodológico demonstraram uma reprodutibilidade adequada dos cefalogramas realizados pelo examinador, uma vez que a precisão das mensurações empregadas nesta pesquisa encontrourse dentro dos parâmetros aceitáveis não comprometendo os resultados e conclusões deste estudo.

\subsection{CARACTERÍSTICAS INICIAIS DOS GRUPOS EXPERIMENTAIS E DO GRUPO CONTROLE (TABELAS 4 a 7 )}

Com o objetivo de avaliar os efeitos de distintos aparelhos ortodônticos/ortopédicos sobre o complexo craniofacial torna-se necessária a utilização de grupos com características morfológicas semelhantes, antes da instituição de qualquer terapia.

As pesquisas mais recentes ${ }^{75,76,88,115,152,153,154,163,164}$ têm mostrado preocupação em avaliar o grau de similaridade entre os grupos, na tentativa de se obter resultados mais confiáveis e menos tendenciosos. 
Neste estudo, efetuaram-se as comparações das medidas cefalométricas iniciais entre os grupos, por meio da análise de Variância ANOVA e do teste de Tukey.

De uma maneira geral, os grupos mostraram-se satisfatoriamente semelhantes na fase pré-tratamento, sendo que das 25 variáveis avaliadas, seis apresentaram diferenças estatisticamente significantes.

As diferenças entre os grupos concentraram-se principalmente nas características do perfil tegumentar. Observou-se que o grupo controle apresentou menor protrusão dos lábios superior e inferior (Ls-Pog'Sn e Li-Pog'Sn) e um ângulo nasolabial mais aberto em relação aos grupos experimentais sendo o responsável pelas diferenças das características do perfil mole.

Em relação à altura facial posterior (S-Go), observou-se um valor significantemente menor no grupo 2 (AEB conjugado) o qual mostrou-se diferente estatisticamente dos demais grupos.

Os comprimentos efetivos da maxila e da mandíbula apresentaram discrepâncias entre os grupos experimentais com maiores valores para o grupo 3.

\subsection{COMPARAÇÃO DOS EFEITOS PRODUZIDOS PELO TRATAMENTO E PELO CRESCIMENTO (TABELAS 8 a 11)}

Para identificar os efeitos do tratamento e compará-los às alterações propiciadas pelo crescimento isoladamente, torna-se necessária a utilização de grupos controles. A simples comparação entre grupos experimentais tratados com distintas abordagens terapêuticas não distingue as alterações produzidas pelos aparelhos daquelas aludidas pelo crescimento craniofacial.

A tendência das pesquisas atuais ${ }^{75,76,88,115,152,153,154,163,164}$ consiste em realizar avaliações longitudinais, comparando-se grupos tratados com outro grupo composto 
de indivíduos que inicialmente apresentavam má oclusão similar. Todavia, este grupo controle não deve ser submetido a nenhuma ação de aparelhos ortodônticos, devendo ainda ser acompanhado por avaliações periódicas pareadas com aquelas do grupo tratado. Este parâmetro tem sido utilizado nas principais investigações que avaliam os efeitos dentoesqueleticofaciais surtidos pelo uso de aparelhos ortopédicos $^{157}$. Contudo, questiona-se esta metodologia sob o aspecto ético. Assim, torna-se difícil a realização de um estudo prospectivo.

Portanto, nesta pesquisa retrospectiva comparou-se dois grupos experimentais com um grupo controle pareado de acordo com a idade, número de indivíduos, gênero, má oclusão e grandezas cefalométricas iniciais, a fim de identificar as alterações dentoesqueléticas e tegumentares produzidas pelo $A E B$ conjugado e pelo Bionator.

De acordo com a proposição do estudo, os diferentes efeitos foram divididos em tópicos e assim serão discutidos:

6.3.1-Componente maxilar;

6.3.2-Componente mandibular;

6.3.3-Relação maxilomandibular;

6.3.4-Relação vertical;

6.3.5-Componente dentoalveolar e,

6.3.6-Perfil tegumentar. 


\subsubsection{Componente maxilar (Figuras 66, 67 e 68)}

Alguns autores não consideram a maxila a principal responsável pelo desenvolvimento da má oclusão de Classe II, 1a divisão, uma vez que esta se encontra bem posicionada (BERTOZ et al. ${ }^{23}$, BRANDÃO; DOMINGUEZRODRÍGUEZ; CAPELOZZA FILHO ${ }^{28}$, CARTER ${ }^{34}$, HENRIQUES et al. ${ }^{72}$, MAIA et al. ${ }^{98}$, MCNAMARA JÚNIOR ${ }^{107}$, NGAN; BYCZEK; SCHEICK ${ }^{117}$, PFEIFFER; GROBÉTY ${ }^{123}$, RIEDEL ${ }^{131}$ SANTOS $^{139}$, URSI; McNAMARA Jr ${ }^{158}$ ) ou até mesmo retruída em relação à base do crânio (ANDERSON; POPOVICH ${ }^{12}$, HENRIQUES et al. ${ }^{74}$, MCNAMARA JÚNIOR $^{107}$, OPPENHEIM ${ }^{120}$, SARHAN; HASHIM ${ }^{145}$ ). Contudo, outros pesquisadores encontraram-na protruída em relação à base do crânio (ALTEMUS $^{9}$, ANDERSON ${ }^{11}$, BACCETTI et al. $^{16}$, DIBBETS ${ }^{46}$, FISK et al. ${ }^{55}$, HENRIQUES et al. ${ }^{72}$, HENRY ${ }^{73}$, MAIA et al. ${ }^{98}$, MAJ; LUZI; LUCCHESE ${ }^{99}$, MARTIN ${ }^{103}$, PROFFIT ${ }^{126}$, ROSENBLUM ${ }^{134}$, ROTHSTEIN ${ }^{135}$, ROTHSTEIN; YOONTARLIE $^{136}$, SALZMANN $^{137}$, SERVOSS $^{146}$ e VALE $^{159}$ ).

A maxila pode apresentar-se com tamanho aumentado e com uma forma atrésica (ALARASHI ${ }^{2}$ ), com os incisivos superiores inclinados para vestibular e os incisivos inferiores para lingual ${ }^{9}$. Sabe-se que o comprimento maxilar aumenta gradativamente com a idade, dos 6 aos 18 anos, cerca de um grau ou um milímetro (pelo menos), fator observado, em ambos os gêneros, por MCNAMARA JÚNIOR ${ }^{108}$ e por MARTINS et al. ${ }^{104}$ Desta forma, espera-se que os aparelhos promovam alterações no componente maxilar.

Os aparelhos avaliados nesta pesquisa, principalmente o AEB conjugado, surtiram efeitos sobre a posição espacial da maxila (referenciada pelo ponto $A$ ). Alguns autores ${ }^{108,150,157}$ destacaram que o ponto $A$ está sujeito às alterações na posição dos incisivos superiores, e pode mascarar a interpretação do posicionamento ântero-posterior da maxila.

Para a avaliação das alterações ocorridas no componente maxilar, utilizourse as grandezas cefalométricas SNA, Nperp-A e Co-A. Os resultados obtidos 
demonstraram diferenças estatísticas significantes entre os grupos. O ângulo SNA e a medida linear Nperp-A, que definem a posição da maxila em relação à base do crânio, diminuíram nos três grupos estudados sendo esta diminuição maior no grupo tratado com o AEB conjugado com diferença significante. O grupo tratado com o Bionator mostrou-se semelhante ao grupo controle, apresentando uma diminuição mais discreta destas medidas.

Sendo assim, verificourse que o AEB conjugado restringiu o desenvolvimento maxilar no sentido ântero-posterior concordando com os relatos de ALMEIDA et al. ${ }^{6,8}$, BASS $^{18}$, CALDWELL; HYMAS; TIMM ${ }^{33}$, FOTIS et al. ${ }^{56}$, HENRIQUES ${ }^{67}$, HENRIQUES et al. $^{69,70}$, MALTAGLIATI ${ }^{100}$, MARTINS ${ }^{105}$, SEÇKIN; SURUCU ${ }^{145}$, THUROW ${ }^{148}$, ÜNER; EROGLU ${ }^{156}$.

Em relação ao Bionator, verificourse um comportamento muito semelhante ao do grupo controle, demonstrando que a interceptação com este aparelho não promove efeitos restritivos sobre o desenvolvimento da maxila no sentido sagital. Resultados similares foram relatados pela maioria dos autores 3,4,7,27,36,38,61,65,71,78,79,81,88,105,111,153,154,165, que não encontraram influência do Bionator sobre o desenvolvimento maxilar. Por outro lado, na literatura alguns autores $45,64,77,94,121,123,147,150,151,160$ demonstraram que o Bionator promoveu uma restrição do crescimento para anterior da maxila, apontada pela diminuição do ângulo SNA.

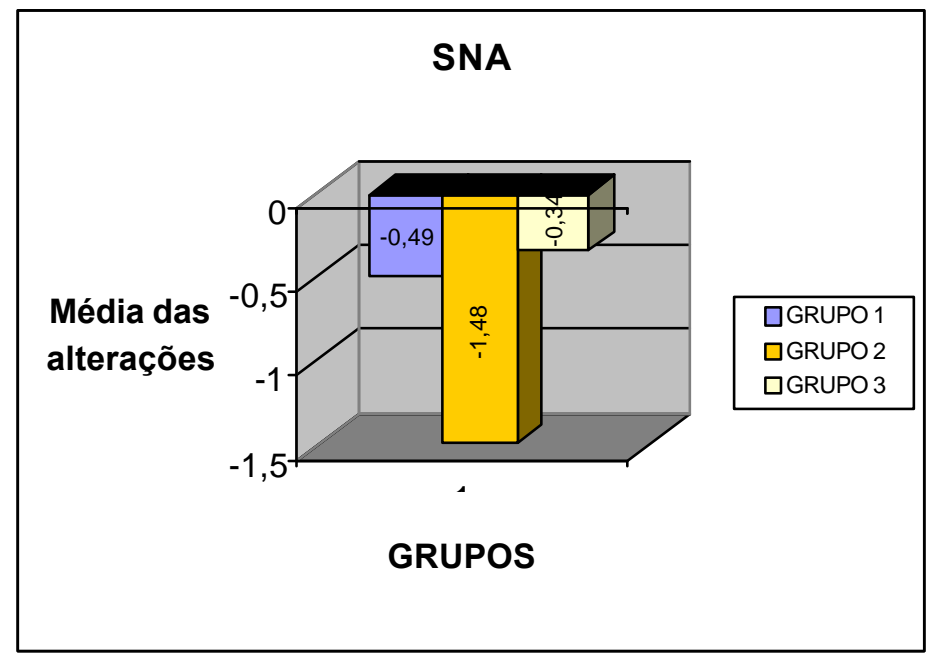

FIGURA 66- Alterações do ângulo SNA nos três grupos. 


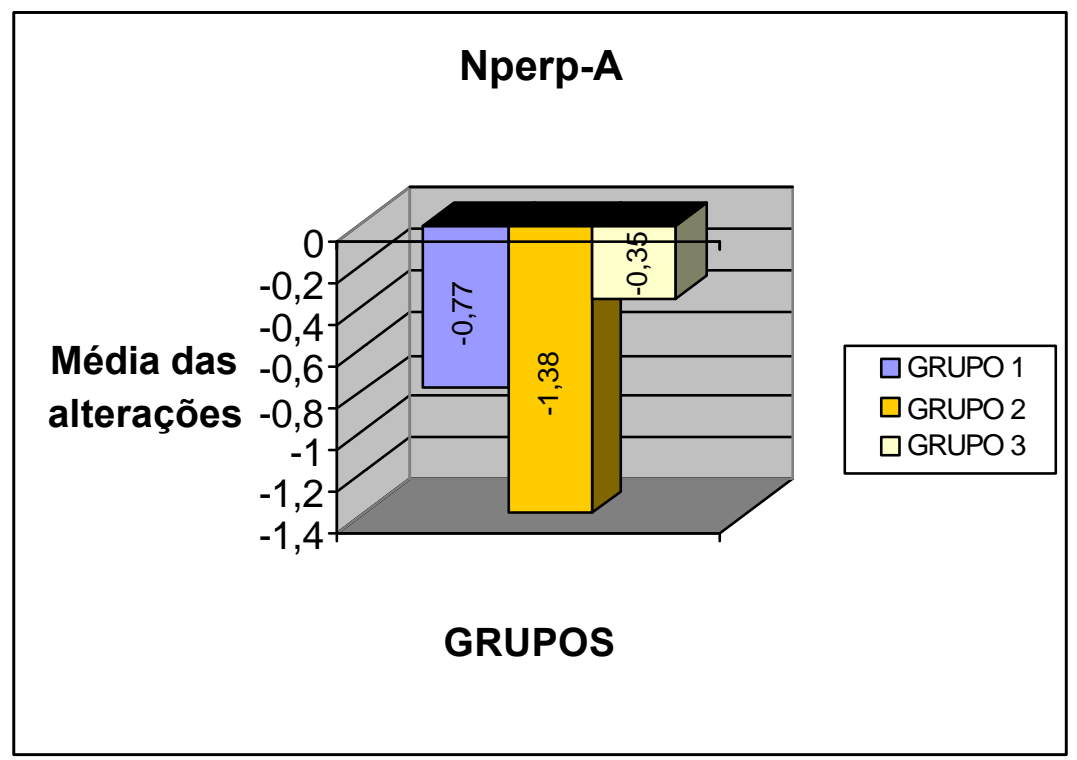

FIGURA 67- Alterações da medida Nperp-A nos três grupos.

Em relação ao comprimento efetivo da maxila, avaliada pela medida linear Co-A notou-se um aumento para todos os grupos, com diferença estatisticamente significante somente entre os grupos 1 e 3 (tabela 8). Deve-se destacar que esta medida é influenciada pelo avanço do ponto condílio devido ao deslocamento anterior da mandíbula em conseqüência do avanço mandibular alusivo ao mecanismo de ação do Bionator, assim, o efeito restritivo sobre a maxila é considerado uma interpretação inadequada.

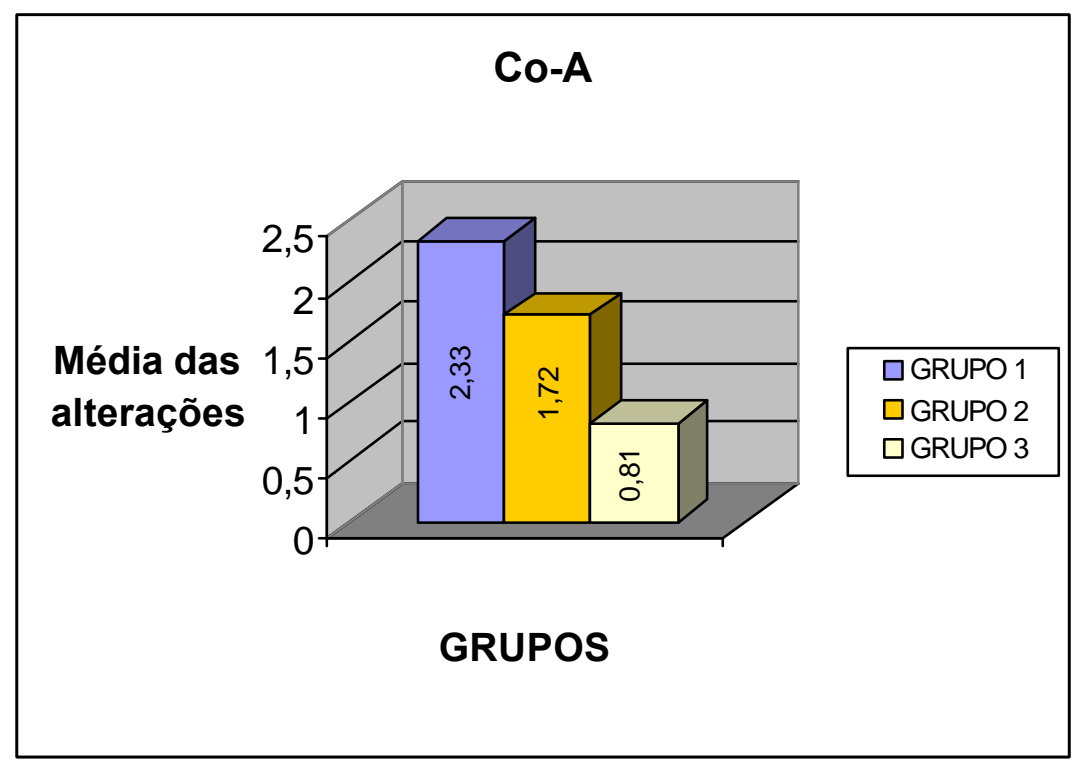

FIGURA 68- Alterações do comprimento efetivo da maxila Co-A nos três grupos. 
Em suma, os resultados desta pesquisa demonstraram que os aparelhos estudados apresentaram efeitos distintos sobre a maxila. Pode-se afirmar que o AEB conjugado promoveu uma restrição no desenvolvimento ântero-posterior da maxila enquanto que o Bionator não influenciou significantemente o posicionamento espacial desta base óssea.

\subsubsection{Componente mandibular (Figuras 69, 70, 71 e 72)}

Embora exista uma extensa variabilidade dos componentes envolvidos na má oclusão de Classe II, $1^{\text {a }}$ divisão o componente mandibular é considerado como um dos maiores responsáveis por esta má oclusão. A maioria dos trabalhos revisados demonstrou uma deficiência no desenvolvimento da mandíbula para anterior $14,16,26,32,40,48,55,62,73,85,87,91,102,103,116,117,126,139$, ou uma retrusão mandibular em relação à maxila $\quad \mathrm{e}$ estruturas cranianas $12,16,18,23,24,28,34,43,72,73,85,89,98,103,107,117,123,129,131,137,139,146,158,159,161$. No entanto, outros pesquisadores (ANDERSON ${ }^{11}$, GILMORE ${ }^{62}$, MAJ; LUZI; LUCCHESE ${ }^{99}$, ROSENBLUM $^{134}$ e ROTHSTEIN ${ }^{135}$, ROTHSTEIN; YOON-TARLIE ${ }^{136}$ ) observaram que na Classe II, 1a divisão, a mandíbula apresenta-se bem posicionada, divergindo da maioria dos estudos.

Neste estudo, avaliou-se o posicionamento mandibular em relação à base do crânio pelas grandezas cefalométricas SNB e Nperp-P. O comprimento efetivo da mandíbula (Co-Gn) e o comprimento do corpo mandibular (Go-Gn) também foram analisados.

O crescimento mandibular normalmente ocorre no sentido póstero-superior deslocando a mandíbula para anterior e para baixo. No entanto, na má oclusão de Classe II, 1a divisão a mandíbula pode não crescer ou não se deslocar adequadamente. Interceptando a má oclusão por meio de aparelhos, objetiva-se estimular ou direcionar o crescimento mandibular. Assim, esperava-se um aumento de todas as grandezas correspondentes ao componente mandibular, principalmente 
nos grupos experimentais. Os resultados mostraram que as medidas SNB e Nperp-P aumentaram apenas nos grupos tratados, sendo que os valores foram maiores no grupo 3, tratado com o Bionator, apresentando diferença estatisticamente significante em relação aos demais grupos.

Corroborando com os resultados obtidos, BASS ${ }^{19,20}$, BISHARA; ZIAJA ${ }^{25}$, BOLMGREN; MOSHIRR ${ }^{27}$, CHANG et al. ${ }^{36}$, CURA et al. $^{41}$, DE VINCENZO ${ }^{44}$, DERRINGER ${ }^{45}$, FREITAS ${ }^{57}$, FREUNTHALLER ${ }^{60}$, GHAFARI; KING; TULLOCH ${ }^{61}$, HENRIQUES et al. ${ }^{71}$, JAKOBSSON; PAULIN ${ }^{77}$, JANSON ${ }^{78,79}$, KEELING ${ }^{88}$, LANGE $^{94}$, MAMANDRAS; ALLEN ${ }^{101}$, MARTINS $^{105}, \mathrm{MEACH}^{109}$, MILLS $^{111}$, OP HEIJ et al. ${ }^{119}$, SCHULHOF; ENGEL ${ }^{144}$, THÜER; INGERVALL; BÜRGIN ${ }^{147}$, TSAMTSOURIS; VEDRENNE ${ }^{150}$, TULLOCH; PHILLIPS; PROFFIT ${ }^{153}$ e TULLOCH et al. $^{154}$, demonstraram que o ângulo SNB aumentou com a utilização do Bionator.

Discordando dos resultados da presente pesquisa, HARVOLD; VARGERVIK ${ }^{64}$, HASHIM ${ }^{65}$, NELSON; HARKNESS; HERBISON ${ }^{115}$, PANCHERZ $^{121}$, VARGERVIK; HARVOLD ${ }^{160}$, não evidenciaram um incremento mandibular resultante do tratamento com o Bionator de Balters.

O grupo tratado com o AEB conjugado também apresentou um discreto aumento na protrusão mandibular, enquanto o grupo controle mostrou uma diminuição do valor de SNB e Nperp-P sugerindo retrusão da mandíbula, no entanto este comportamento distinto entre os grupos não alcançou diferença estatisticamente significante.

Com exceção de CALDWELL; HYMAS; TIMM ${ }^{33}$ que verificaram uma diminuição do ângulo SNB, os resultados de todos os outros pesquisadores $18,56,67,68,70,88,100,105,145,156$ que avaliaram os efeitos do AEB conjugado corroboraram com os desta investigação. 
Contrariando os resultados desta pesquisa, diversos autores $3,7,27,33,36,61,94,100,105,157$ verificaram um aumento no valor de SNB nos pacientes com má oclusão de Classe II, 1a divisão não tratados.

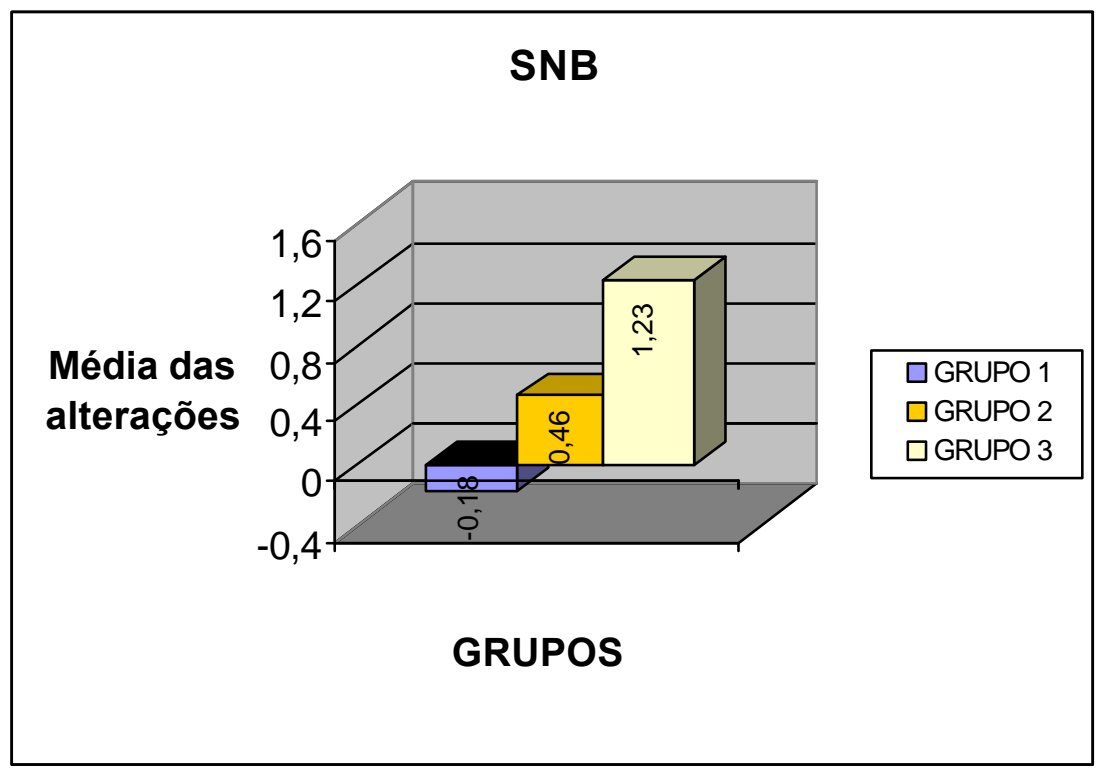

FIGURA 69- Alterações do ângulo SNB nos três grupos.

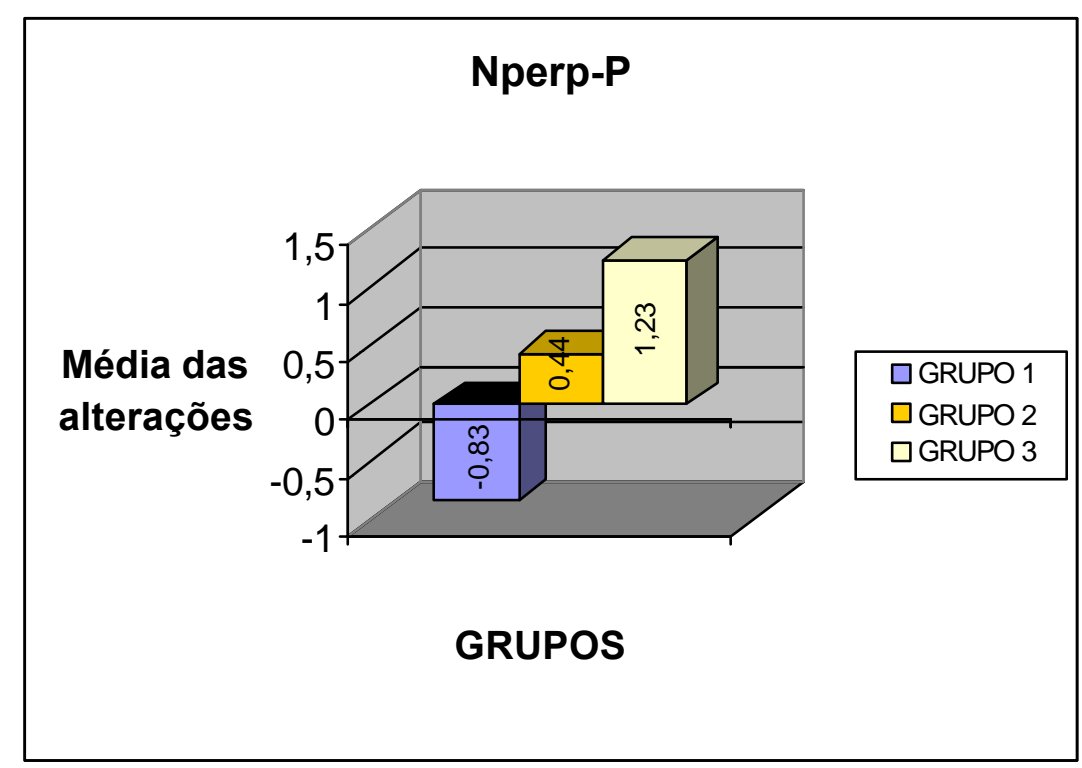

FIGURA 70- Alterações da medida Nperp-P nos três grupos. 
As dimensões mandibulares representadas pelas medidas lineares Co-Gn e Go-Gn, aumentaram nos três grupos, revelando-se sensivelmente maiores no grupo tratado com o AEB conjugado porém sem denotar uma diferença estatisticamente significante.

Discordando dos resultados deste estudo ALMEIDA ${ }^{3}$, ALMEIDA et al. ${ }^{4,5,7}$, DERRINGER ${ }^{45}$, FALTIN JUNIOR et. al. ${ }^{51}$, SCHULHOF; ENGEL ${ }^{144}$, observaram diferença significante no aumento do comprimento do corpo mandibular, avaliando pacientes com Classe II, tratados com o Bionator comparados a um grupo controle.

O aumento do comprimento efetivo da mandíbula (Co-Gn) parece ser uma unanimidade ontre os autores pesquisados $3,4,19,20,27,36,44,45,57,60,61,71,77,78,79,88,94,101,111,144,153,154,163,164$, embora nem todos, inclusive este estudo, tenham observado uma diferença significante entre os grupos tratados e os grupos controle $37,64,65,100,121$.

Embora as alterações ocorridas no comprimento efetivo da mandíbula não demonstrarem diferença estatística, os resultados podem ser considerados clinicamente significantes, uma vez que os grupos tratados exibiram um aumento da taxa de crescimento mandibular de pelo menos 30\% em relação ao grupo controle.

Um resultado surpreendente foi o maior aumento do comprimento total e do corpo mandibular no grupo tratado com o AEB conjugado, em comparação com o aparelho Bionator. Em relação ao grupo controle, os valores indicaram uma taxa de crescimento do comprimento efetivo da mandíbula e do corpo nos casos tratados com AEB conjugado cerca de $70 \%$ e de $30 \%$ maiores, respectivamente. Estes resultados se respaldam na assertiva de YOU et al. ${ }^{167}$ que consideram fundamental para o tratamento da má oclusão de Classe II, 1a divisão a desoclusão dos dentes, liberando o crescimento mandibular. O estudo de KEELING et al. ${ }^{88}$ também está de acordo confirmando que o tratamento da má oclusão de Classe II, 1a divisão com o AEB com placa de mordida (levantamento oclusal) produz um deslocamento significante da mandíbula para anterior, no entanto os autores afirmaram que a 
relação entre o uso da placa de levantamento oclusal com o maior crescimento mandibular ainda não está esclarecida. Parece-nos evidente que o AEB conjugado influencia positivamente o crescimento da mandíbula porém não foi possível com este estudo demonstrar estatisticamente este efeito. No entanto, cabe ressaltar, mais uma vez que clinicamente os resultados podem ser significantes.

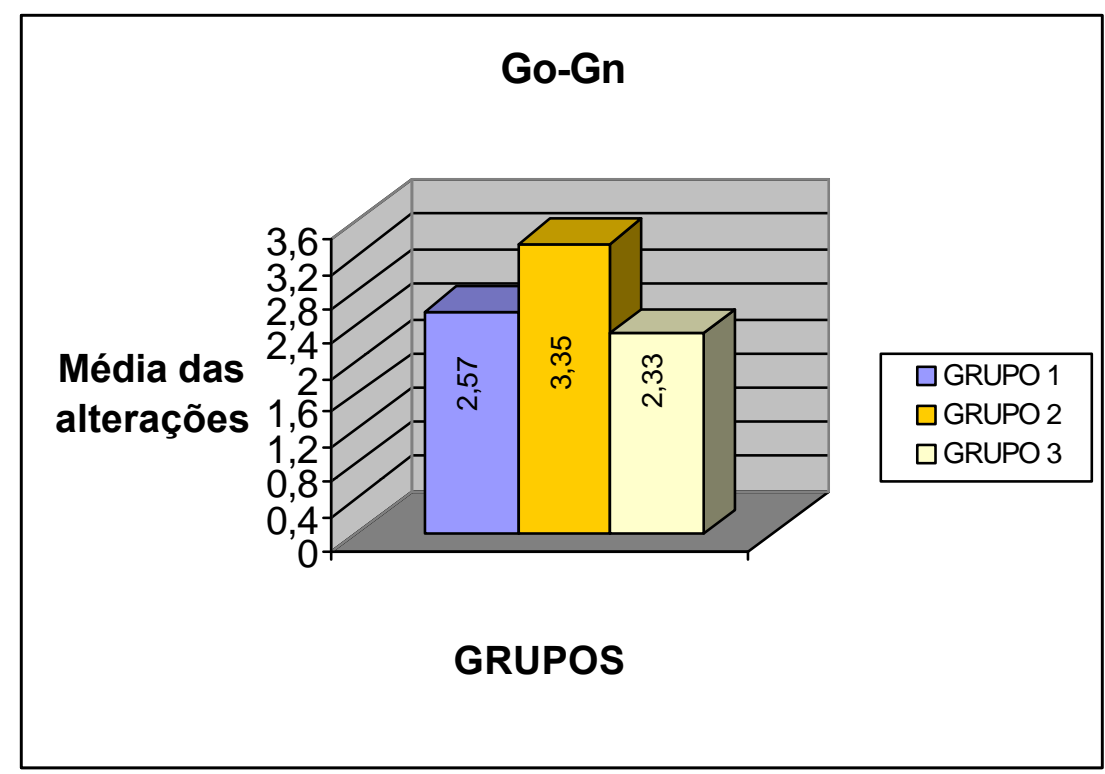

FIGURA 71- Alterações da medida Go-Gn nos três grupos.

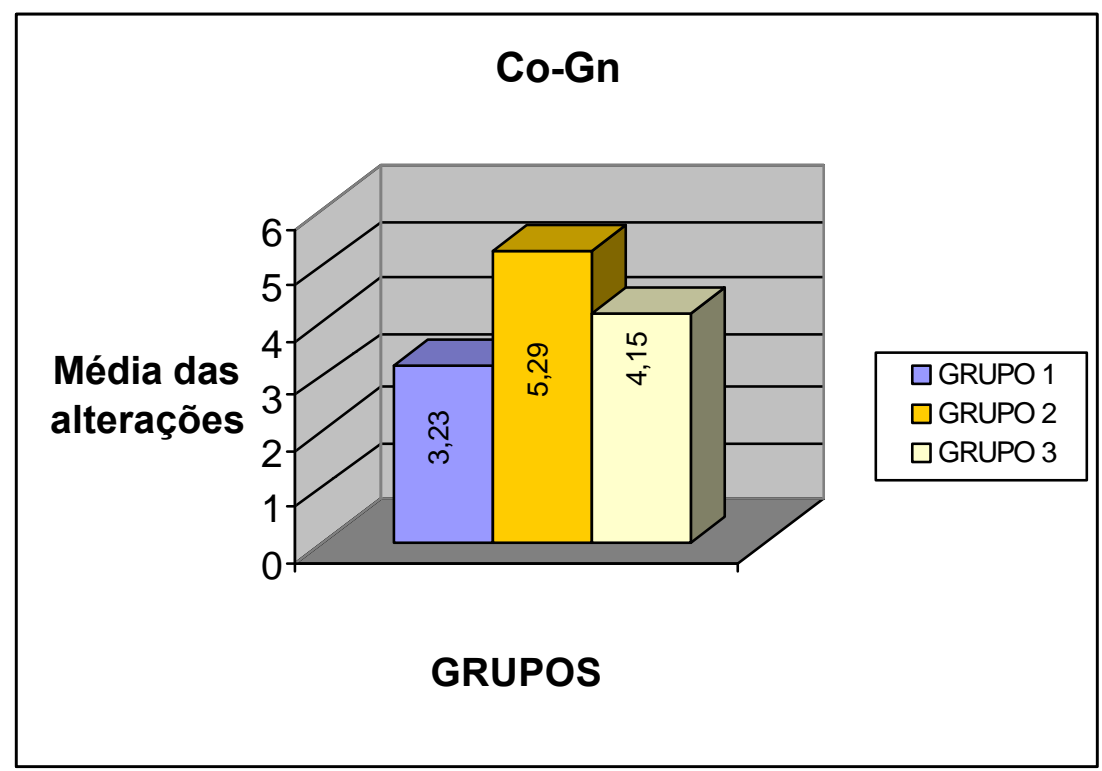

FIGURA 72- Alterações do comprimento efetivo da mandíbula (Co-Gn) nos três grupos. 
Concluindo este tópico, deve-se ressaltar que $O$ AEB conjugado e principalmente o Bionator, embora de forma diferenciada, influenciaram expressivamente o crescimento mandibular, promovendo uma protrusão e um aumento das dimensões mandibulares.

\subsubsection{Relação maxilomandibular (Figuras 73 e 74)}

Em conseqüência às alterações ocorridas nos componentes maxilar e mandibular, a relação sagital entre as bases ósseas e a convexidade facial melhorou significantemente nos grupos tratados.

Neste estudo foram utilizados os ângulos ANB e NAP para análise da relação maxilomandibular. Estas grandezas foram escolhidas pela popularidade em pesquisas ortodônticas.

O ajuste sagital entre as bases ósseas ocorre normalmente pelo crescimento diferencial entre a maxila e a mandíbula. Neste período observa-se uma diminuição do ângulo ANB e uma tendência de melhora da convexidade facial, desde que os vetores de crescimento se processem em equilíbrio na direção ântero-inferior.

Como era de se esperar, os ângulos ANB e NAP diminuíram significantemente nos grupos experimentais possibilitando uma melhora no relacionamento maxilomandibular e na convexidade facial. Comparando-se os grupos tratados, não foi verificada diferença estatística, embora o grupo 2 tenha apresentado uma diminuição destes ângulos sensivelmente maior que o grupo tratado com o Bionator. No entanto, quando da comparação dos grupos experimentais com o grupo controle, observou-se uma diferença estatisticamente significante, uma vez que os ângulos ANB e NAP diminuíram com maior intensidade nos grupos 2 e 3 e menos expressivamente no grupo 1 . 


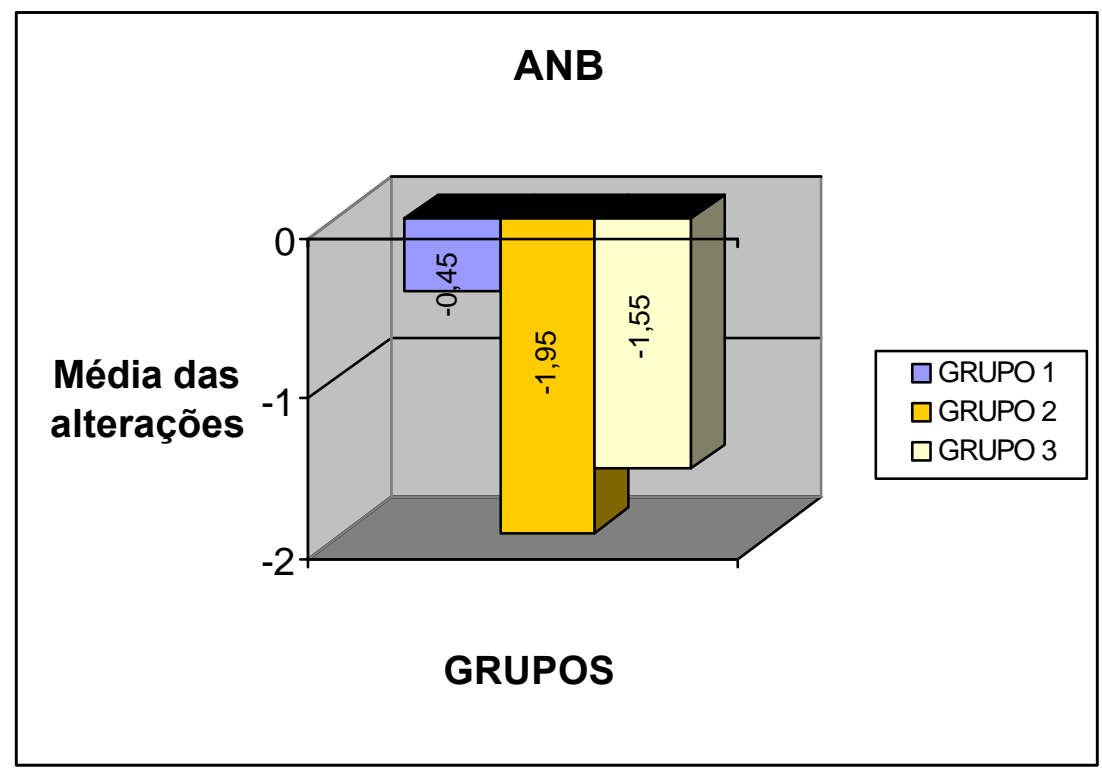

FIGURA 73- Alterações do ângulo ANB nos três grupos.

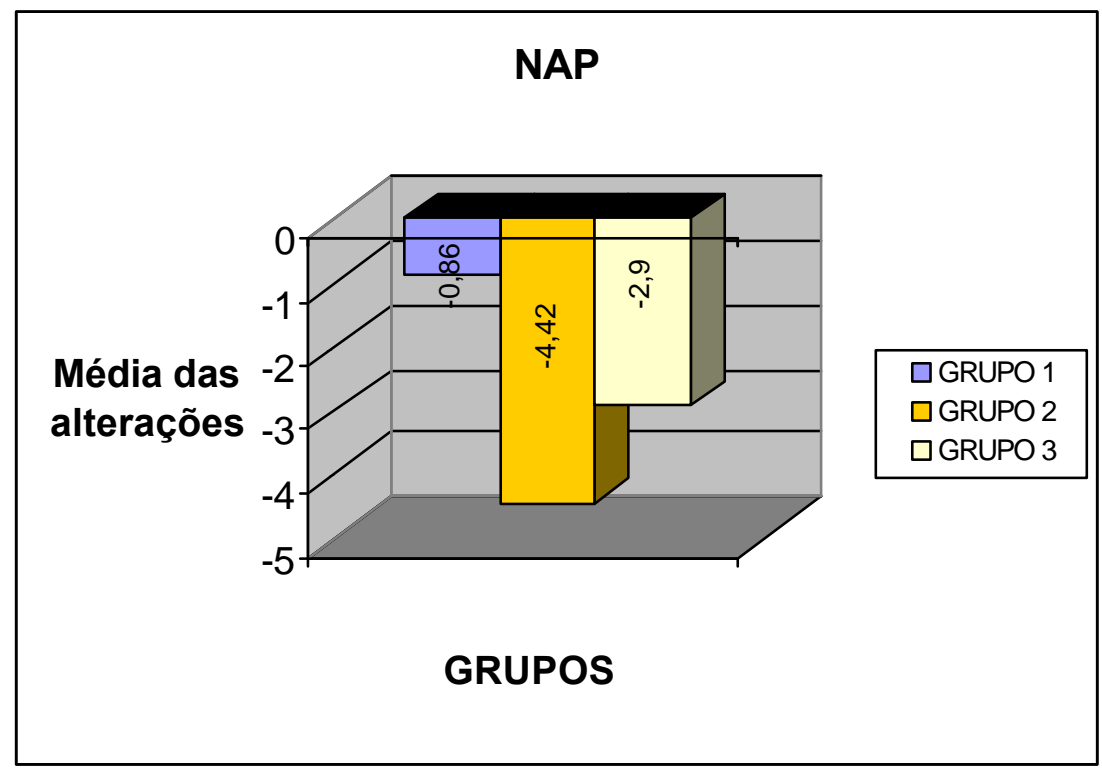

FIGURA 74- Alterações do ângulo NAP nos três grupos. 
Este resultado é substanciado na literatura por diversos autores ALMEIDA $^{3}$, ALMEIDA; HENRIQUES; URS1 ${ }^{4}$, ALMEIDA et al. ${ }^{7}$ CHANG et al. ${ }^{36}$, CURA et al. $^{41}$, DERRINGER ${ }^{45}$, HENRIQUES et al. ${ }^{71}$, JAKOBSSON; PAULIN ${ }^{77}$, LANGE et al. ${ }^{94}$, MILLS $^{111}$, PANCHERZ ${ }^{121}$, THÜER; INGERVALL; BÜRGIN ${ }^{147}$, TULLOCH; PHILLIPS; PROFFIT ${ }^{153}$, TULLOCH et al. $^{154}$, WIESLANDER; LAGERSTRÖM ${ }^{165}$, que verificaram com o uso do Bionator uma melhora significante no grau de discrepância maxilomandibular e no ângulo de convexidade esquelética.

Em relação ao AEB conjugado a literatura corrobora com os resultados desta pesquisa (ALMEIDA et al. ${ }^{6,8}$, BASS $^{18}$, CALDWELL; HYMAS; TIMM ${ }^{33}$, DERRINGER ${ }^{45}$, FOTIS et al. $^{56}$, HENRIQUES ${ }^{67}$, HENRIQUES et al. ${ }^{69}$, MALTAGLIATI ${ }^{100}$, MARTINS ${ }^{105}$, SEÇKIN; SURUCU ${ }^{145}$, ÜNER; EROGLU ${ }^{156}$ ).

Deve-se salientar que os aparelhos afetaram a relação maxilomandibular de maneira um pouco distinta. O AEB conjugado promoveu alterações mais expressivas no componente maxilar e o Bionator produziu efeitos quase que exclusivamente na mandíbula.

\subsubsection{Relação vertical (Figuras 75, 76, 77 e 78)}

Uma das características mais marcantes da má oclusão de Classe II, 1a divisão é o comportamento das bases ósseas no sentido vertical. Comumente nesta má oclusão observa-se um excesso vertical de maxila, uma rotação horária da mandíbula e concomitantemente um aumento da AFAl 16,32,48,72,85,98,107,117,139,159,161. Esta morfologia agrava a discrepância ântero-posterior. Assim, torna-se imprescindível o conhecimento dos efeitos suscitados por distintos aparelhos na correção desta entidade, buscando um controle vertical.

Para análise das alterações no componente vertical da face foram utilizadas as grandezas cefalométricas SN.Go Gn, SN.PP, AFAl e S-Go. 
As medidas angulares (SN.GoGn e SN.PP) que avaliam a inclinação dos planos mandibular e palatino em relação à base do crânio, não demonstraram alteração significante entre os grupos. No entanto, nos grupos 1 e 2 verificou-se uma tendência ao fechamento do ângulo do plano mandibular, enquanto que no grupo 3 ocorreu um discreto aumento. Pode-se considerar que o uso do AEB conjugado, diferentemente dos efeitos decorrentes do uso isolado do AEB (cervical), controlou o crescimento da face no sentido vertical. Isto sugere que mesmo diante de uma má oclusão de Classe II, $1^{a}$ a divisão com um padrão de crescimento desfavorável (vertical) pode-se utilizar este aparelho esperando resultados satisfatórios.

Estes resultados estão de acordo com diversos pesquisadores 3,5,33,67,68,69,77,94,104,105,156, que afirmaram que os aparelhos ortopédicos não influenciam o padrão de crescimento craniofacial. Em contrapartida, outros estudos demonstraram alterações do padrão de crescimento decorrentes da abordagem ortopédica BOLMGREN; MOSHIR27, CHANG et al. ${ }^{36}$, COURTNEY; HARKNESS; HERBISON $^{38}$, DERRINGER ${ }^{45}$, MEACH $^{109}$, NELSON; HARKNESS; HERBISON ${ }^{115}$, SCHULHOF; ENGEL ${ }^{144}$ e WIESLANDER; LAGERSTRÖM ${ }^{165}$.

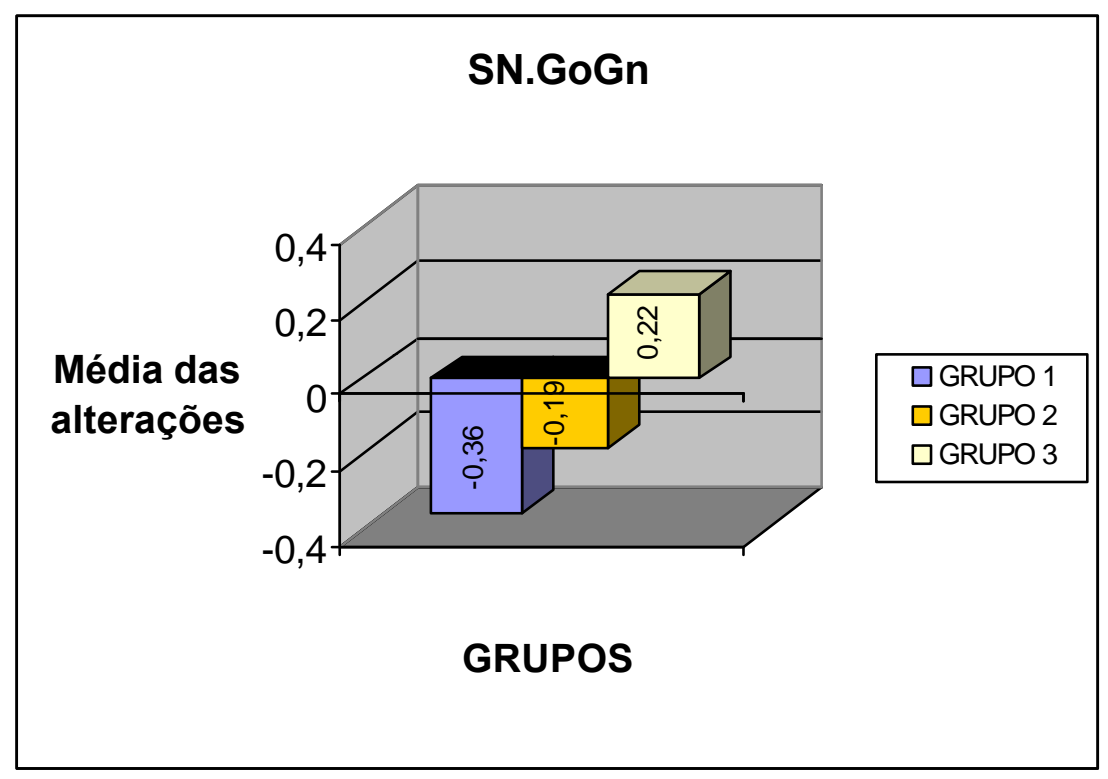

FIGURA 75- Alterações do ângulo SN.GoGn nos três grupos. 


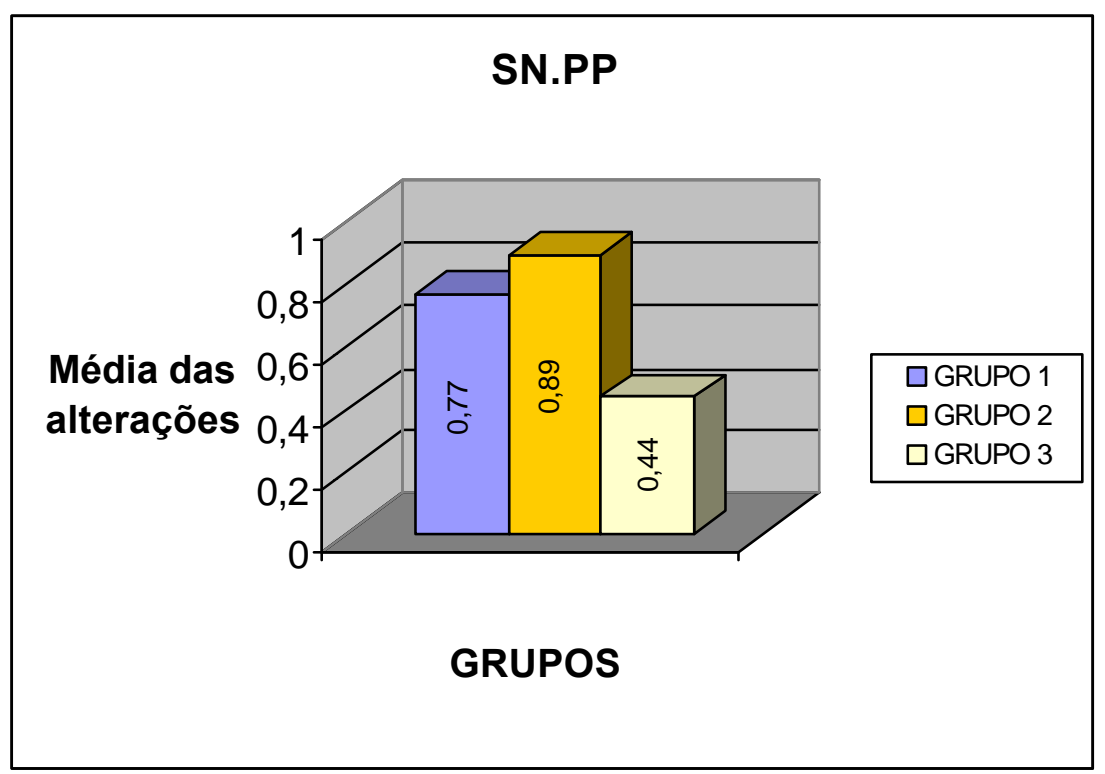

FIGURA 76- Alterações do ângulo SN.PP nos três grupos.

A AFAI e a medida S-Go possibilitou a verificação das alterações no sentido vertical da face, onde se notou um comportamento uniforme no aumento destas grandezas nos três grupos, sem denotar diferença estatística. O grupo tratado com o Bionator apresentou um maior aumento destas medidas, seguido do grupo 2 e do grupo controle, que apresentou menores valores porém não diferente estatisticamente dos grupos experimentais.

Estes resultados contrariam muitos estudos que demonstraram um aumento significante da AFAI 27,33,36,38,45,71,75,77,94,105,111,115,150,157,160,163,165 e da altura facial posterior ${ }^{3,94}$ nos pacientes que utilizaram aparelhos ortopédicos em relação aos grupos de pacientes não tratados. E concordam com outras pesquisas, que embora tenham observado um aumento da $\mathrm{AFAl}^{3,67,69}$ não notaram diferença significante entre grupos tratados e controle. 


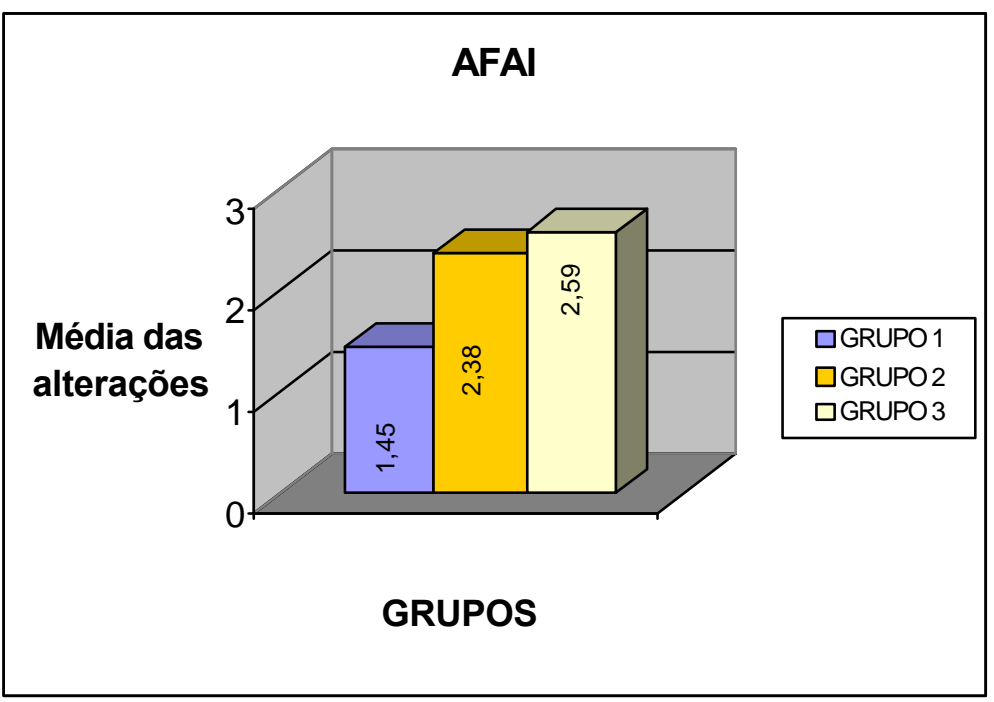

FIGURA 77- Alterações da altura facial ântero-inferior (AFAI) nos três grupos.

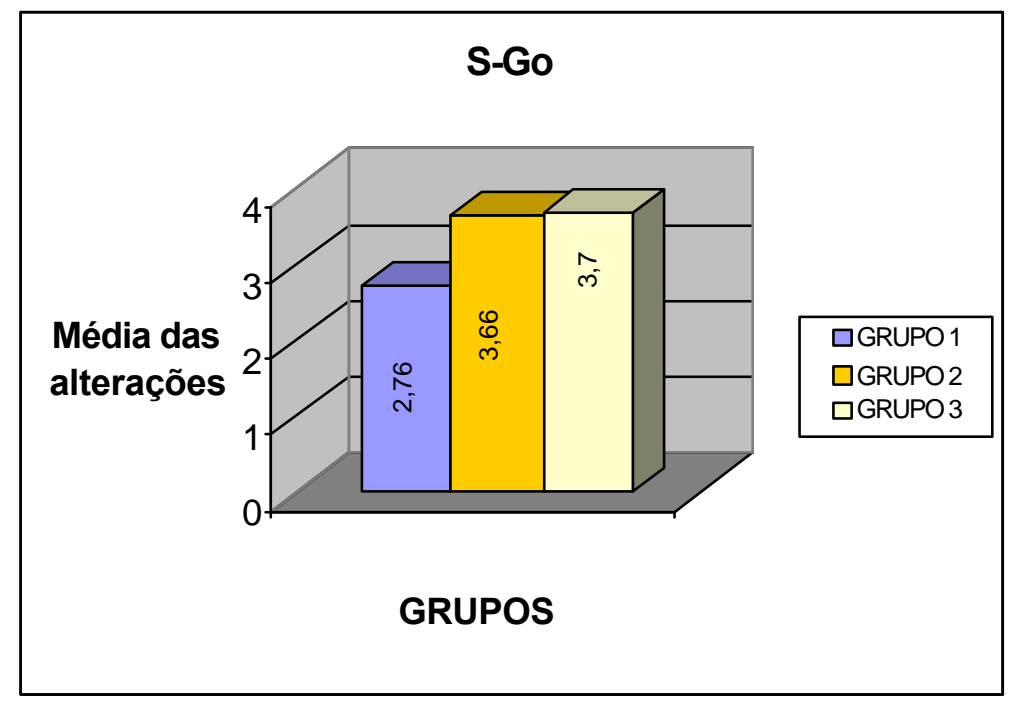

FIGURA 78- Alterações da altura facial posterior (S-Go) nos três grupos.

No entanto, como característica da má oclusão de Classe II, $1^{\underline{a}}$ divisão esperava-se um aumento de todas as grandezas cefalométricas avaliadas para o componente vertical. Concluindo, os resultados demonstraram que a interceptação desta má oclusão com o AEB conjugado e com o Bionator não alteraram o padrão de crescimento e não aumentaram demasiadamente as alturas faciais. Assim, podese inferir que os aparelhos mencionados apresentaram bons efeitos no sentido vertical, principalmente em relação ao AEB conjugado que apresentou um controle vertical sobre o plano mandibular. 


\subsubsection{Componente dentoalveolar}

Os aparelhos ortopédicos promovem a correção da má oclusão de Classe II, $1^{\text {a }}$ divisão por meio de movimentações dentárias e alterações esqueléticas. Nos tópicos anteriores discutiu-se sobre os efeitos esqueléticos produzidos pelo AEB conjugado e pelo Bionator. A seguir, serão avaliadas e discutidas, separadamente as alterações dentárias do arco superior e do arco inferior.

Avaliou-se o comportamento dos dentes superiores de acordo com as grandezas cefalométricas $\underline{1}$.NA, $\underline{1}-\mathrm{NA}, \underline{1}-\mathrm{FHp}, \underline{6}-\mathrm{PP}$ e $\underline{6}-\mathrm{FHp}$.

DENTES SUPERIORES (Figuras 79, 80, 81 e 82)

Como característica patognomônica da má oclusão de Classe II, $1^{1 \underline{a}}$ divisão os incisivos superiores apresentam-se vestibularizados e protruídos na base óssea $14,23,28,34,48,55,87,89,98,99,107,123,135,139,159$

Os resultados desta pesquisa evidenciaram que os aparelhos avaliados promoveram alterações significantes no posicionamento dos incisivos superiores (1.NA e 1-NA). O comportamento deste dentes mostrou-se distinto em relação aos grupos experimentais e controle. Enquanto o grupo 1 (controle) experimentou uma vestibularização e protrusão dos incisivos superiores, os grupos tratados mostraram a efetividade do tratamento com os incisivos inclinados para lingual e retruídos na base óssea após a intervenção. Esta diferença entre os grupos alcançou significância estatística. Entretanto, no grupo 2 (AEB conjugado) observourse uma maior lingualização e retrusão dos incisivos, comparado ao grupo 3, com diferença estatisticamente significante. Assegura-se, deste modo, que os aparelhos responderam de forma similar, porém com intensidade diferente quanto à inclinação para lingual e retrusão dos incisivos superiores.

Compulsando a literatura em relação ao AEB conjugado, quase todos os pesquisadores como ALMEIDA et al. ${ }^{6,8}$, CALDWELL;HYMAS;TIMM ${ }^{33}$, FOTIS et al. ${ }^{56}$, 
HENRIQUES ${ }^{67}$, HENRIQUES et al. ${ }^{69}$, JOFFE; JACOBSON ${ }^{82}$, MALTAGLIATI ${ }^{100}$, MARTINS ${ }^{105}$, ROTHSTEIN ${ }^{135}$ evidenciaram uma inclinação para lingual e retrusão dos incisivos superiores. Apenas HENRIQUES et al. ${ }^{70}$, THUROW ${ }^{148}$ e ÜNER; EROGLU ${ }^{156}$ não obtiveram os mesmos efeitos com o AEB conjugado.

De acordo com os resultados desta investigação os estudos de ALMEIDA et al. ${ }^{5,7}$, BASS ${ }^{19,20}$, BISHARA; ZIAJA ${ }^{25}$, BOLMGREN; MOSHIRR ${ }^{27}$, CHANG et al. ${ }^{36}$, COURTNEY; HARKNESS; HERBISON ${ }^{38}$, CURA et al. ${ }^{41}$, DRAGE; HUNT ${ }^{47}$, FREITAS ${ }^{57}$, HENRIQUES et al. ${ }^{71}$, JANSON ${ }^{78,79}$, JANSON; HASUND ${ }^{81}$, MILLS ${ }^{111}$, PANCHERZ ${ }^{121}$, REMMER et al. $^{128}$, THÜER; INGERVALL; BÜRGIN ${ }^{147}$, TSAMTSOURIS; VEDRENNE ${ }^{150}$, VARGERVIK; HARVOLD ${ }^{160}$, WIESLANDER; LAGERSTRÖM $^{165}$, também concluíram que o ativador/Bionator, atua efetivamente na correção da má oclusão de Classe II, $1^{\text {a }}$ divisão retruindo e inclinando os incisivos superiores para lingual.

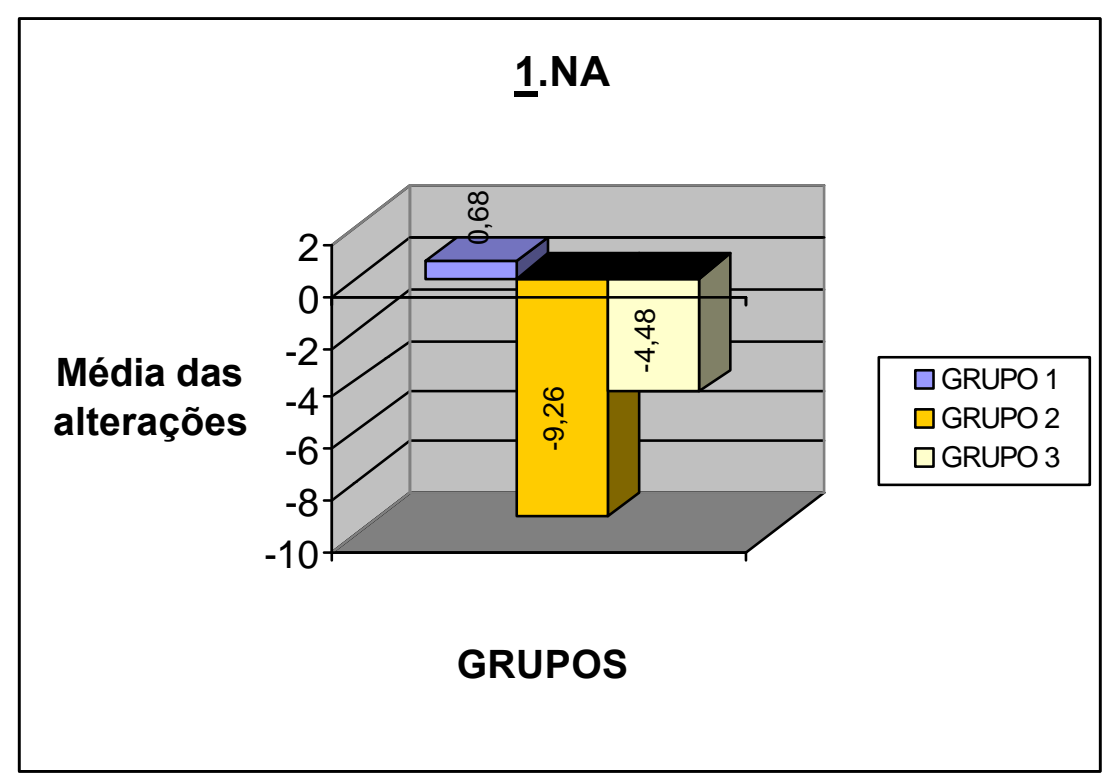

FIGURA 79- Alterações do ângulo 1. NA nos três grupos. 


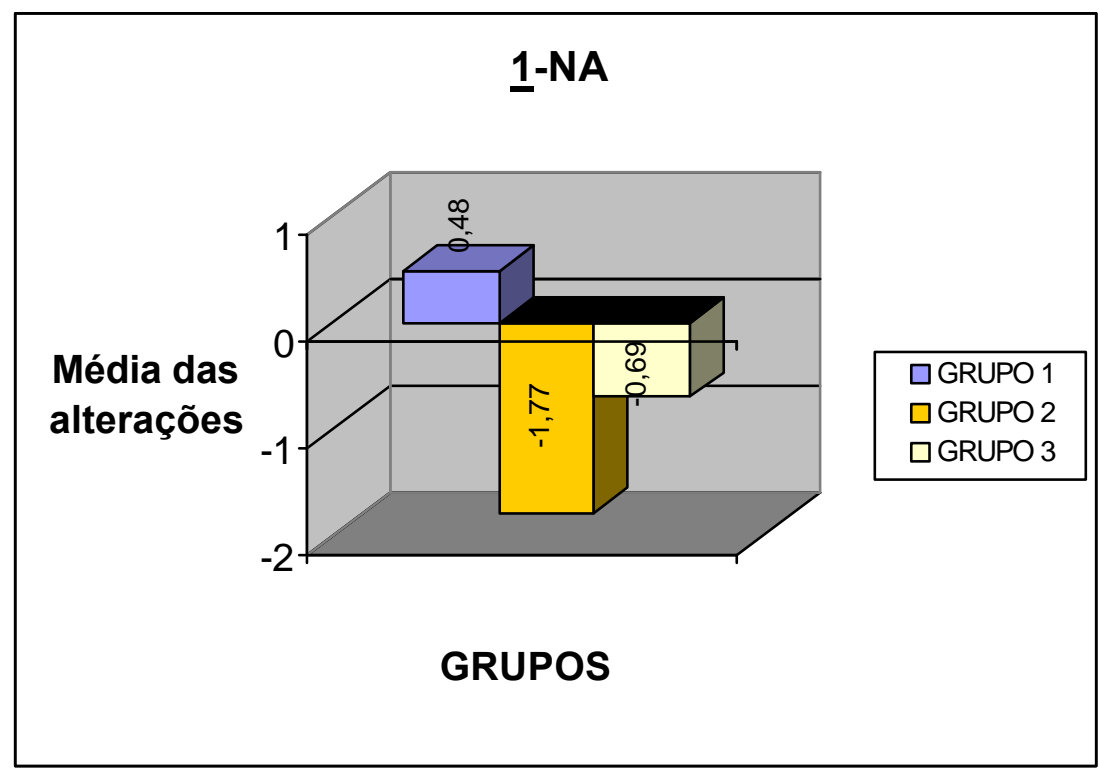

FIGURA 80- Alterações da medida 1-NA nos três grupos.

A divergência dos resultados em relação à intensidade da inclinação para lingual e retrusão dos incisivos superiores observada entre os grupos tratados ocorre em função do arco vestibular do AEB conjugado tocar ativamente a superfície vestibular destes dentes, enquanto no Bionator este arco geralmente não toca ou toca suavemente estes dentes. No entanto, a verticalização dos incisivos superiores pode ser altamente favorável nos casos de um trespasse horizontal acentuado com os incisivos inclinados para vestibular, características estas, freqüentemente observada na má oclusão de Classe II, $1{ }^{\text {a }}$ divisão ${ }^{25}$. Por outro lado, uma lingualização excessiva destes dentes pode limitar o deslocamento anterior da mandíbula.

O posicionamento dos primeiros molares superiores no sentido vertical aferido pela medida $\underline{6}$-PP demonstrou similaridade nos três grupos, não obstante ocorreu um menor aumento nos grupos tratados, sem diferença estatística significante. Este efeito é de extrema importância, uma vez que a extrusão excessiva dos molares superiores é indesejada na correção da má oclusão de Classe II, 1a divisão. 
Em relação à posição dos primeiros molares superiores no sentido ânteroposterior, avaliada pela grandeza $\underline{6}-\mathrm{FHp}$, verificou-se uma distalização destes dentes no grupo tratado com o AEB conjugado enquanto no grupo 3 (Bionator) houve suave mesialização e no grupo controle, como resultado do crescimento e desenvolvimento maxilar, o deslocamento para mesial foi maior. No entanto, observoutse diferença estatisticamente significante apenas entre o grupo controle e o tratado com o AEB conjugado o que está de acordo com os estudos de CARTER ${ }^{34}$, DERRINGER ${ }^{45}$, FOTIS et al. ${ }^{56}$, HENRIQUES ${ }^{67}$, MALTAGLIATI ${ }^{100}$, MARTINS $^{105}$, THUROW $^{148}$, ÜNER; EROGLU ${ }^{156}$. É importante ressaltar que no grupo 3 os molares apresentaram menor mesialização que no grupo controle, porém sem diferença estatística.

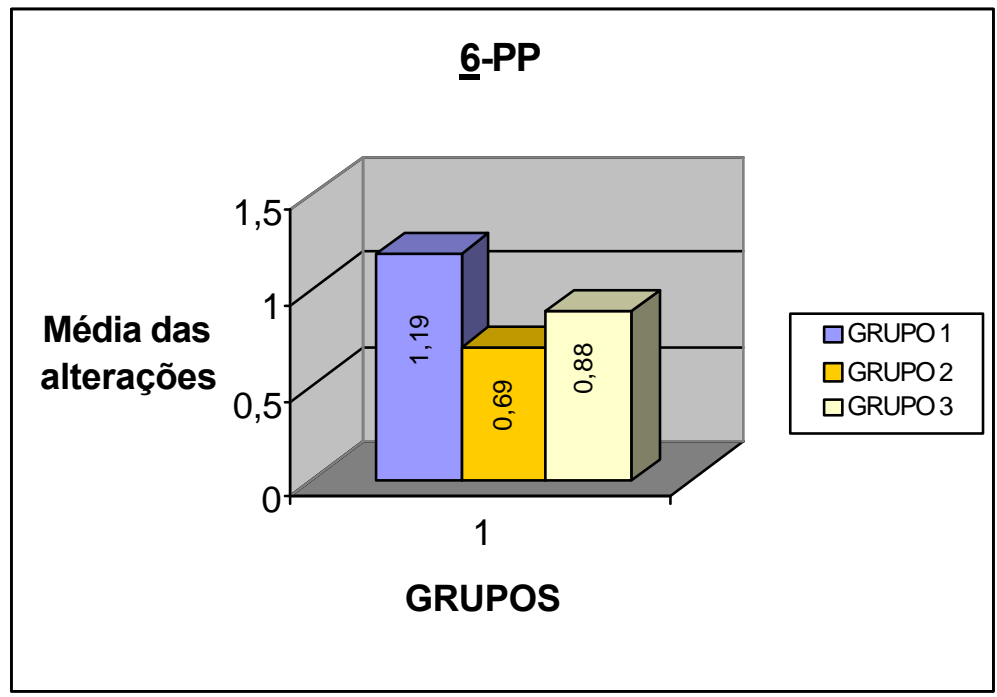

FIGURA 81 - Alterações da medida $\underline{6}$-PP nos três grupos.

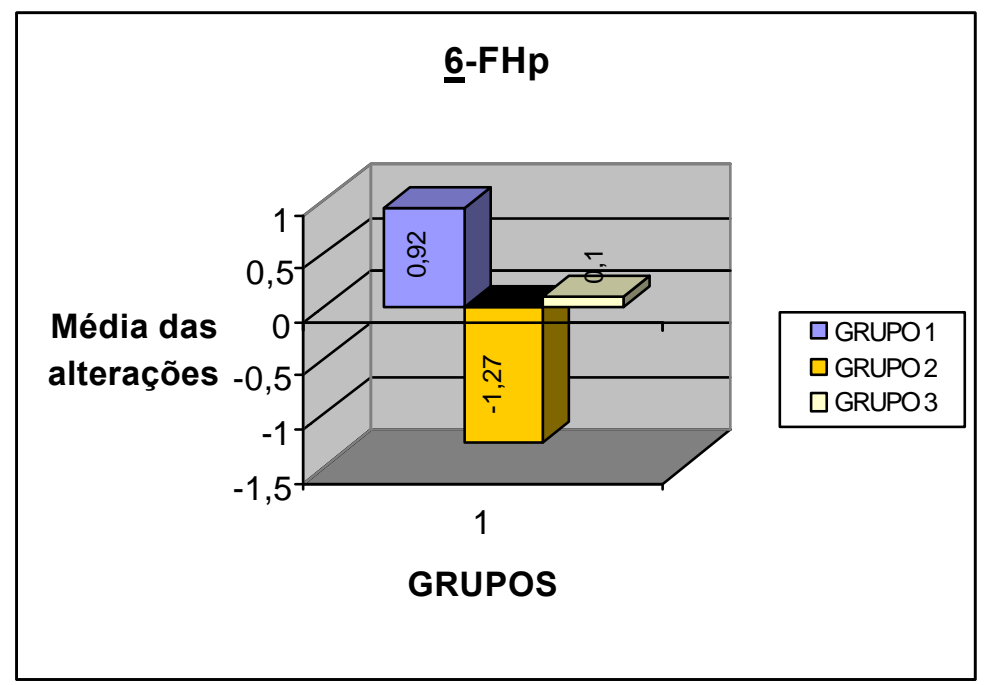

FIGURA 82- Alterações da medida $\underline{6}-\mathrm{FHp}$ nos três grupos. 
DENTES INFERIORES (Figuras 83, 84, 85, 86 e 87)

Para avaliação do comportamento dos dentes inferiores foram utilizadas as medidas angulares $\overline{1}$.NB e IMPA e as medidas lineares $\overline{1}-\mathrm{NB}, \overline{6}-\mathrm{GoMe}$ e $\overline{6}$-FHP.

O posicionamento dos incisivos inferiores decorrente dos tratamentos instituídos evidenciou efeitos distintos e estatisticamente significantes em relação ao grupo controle. No grupo tratado com o AEB conjugado, os incisivos lingualizaram e retruíram, provavelmente devido à lingualização considerável dos homólogos superiores. Outro provável fator responsável pela verticalização dos incisivos inferiores no grupo 2 é a ação do lábio inferior sobre esses dentes, uma vez que o AEB conjugado promove a desoclusão, abrindo a mordida, e aumentando a pressão labial nesta área. O grupo tratado com o Bionator apresentou uma inclinação para vestibular e protrusão maior do que o grupo controle com diferença estatisticamente significante. O grupo controle por sua vez apresentou discreta vestibularização e protrusão dos incisivos na base óssea.

Os estudos de CALDWELL; HYMAS; TIMM ${ }^{33}$, HENRIQUES et al. ${ }^{69} \mathrm{e}$ MALTAGLIATI ${ }^{100}$ corroboram com estes resultados obtidos no grupo tratado com o AEB conjugado e somente a pesquisa de MARTINS ${ }^{105}$ discorda destes efeitos mostrando que os incisivos inferiores não foram influenciados pelo tratamento.

Concordando com os resultados referentes ao Bionator, ALMEIDA ${ }^{3}$, ALMEIDA; HENRIQUES; URS1 ${ }^{4}$, ALMEIDA et al. ${ }^{7}$, BISHARA; ZIAJA ${ }^{25}$, CHANG et al. $^{36}$, DRAGE; HUNT ${ }^{47}$, HENRIQUES et al. ${ }^{71}$, JANSON ${ }^{78,79}$, JANSON; HASUND ${ }^{81}$, NELSON; HARKNESS; HERBISON ${ }^{115}$, PANCHERZ ${ }^{121}$, THÜER; INGERVALL; BÜRGIN ${ }^{147}$, TSAMTSOURIS; VEDRENNE ${ }^{150}$, verificaram uma inclinação para vestibular e maior protrusão dos incisivos inferiores. De modo contrário, BOLMGREN; MOSHIRR , FREITAS ${ }^{57}$, WIESLANDER; LAGERSTRÖM ${ }^{165}$, demonstraram que os incisivos não sofreram alterações durante o tratamento com o ativador. 


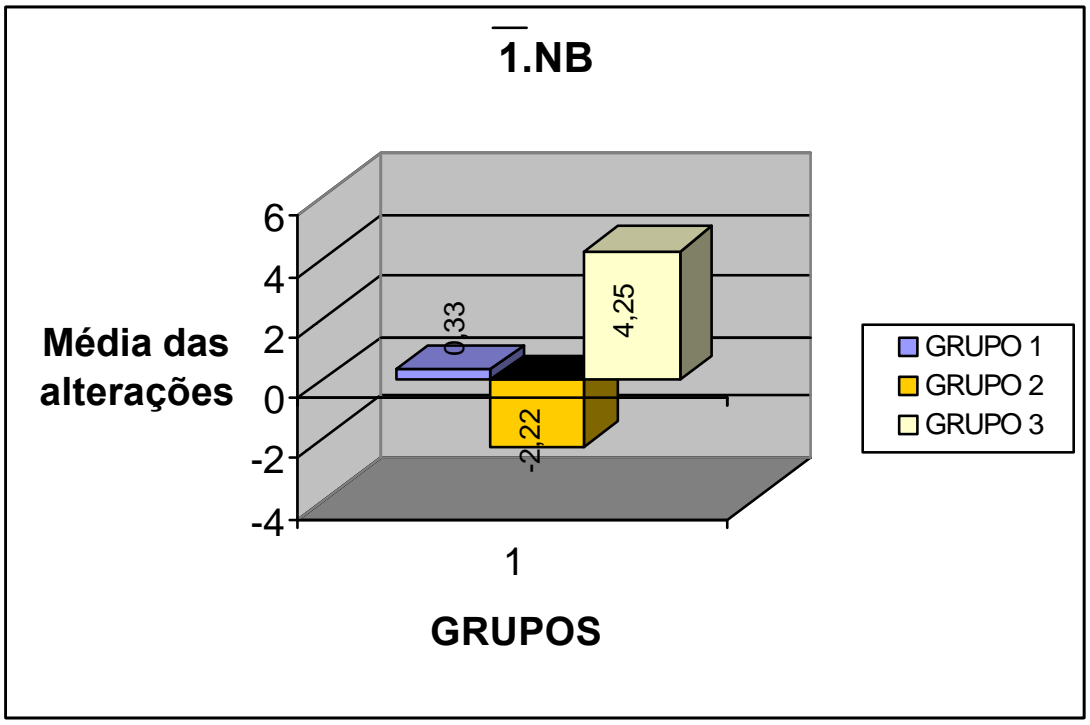

FIGURA 83- Alterações do ângulo 1..NB nos três grupos.

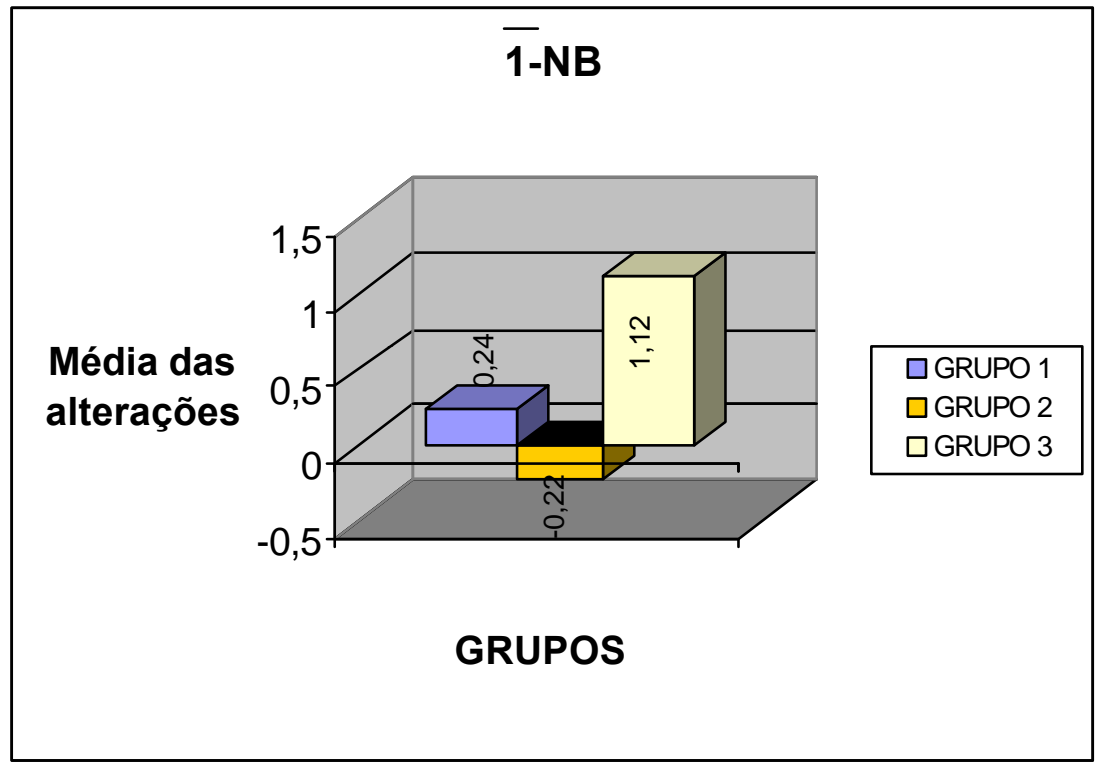

FIGURA 84- Alterações da medida 1̄-NB nos três grupos. 


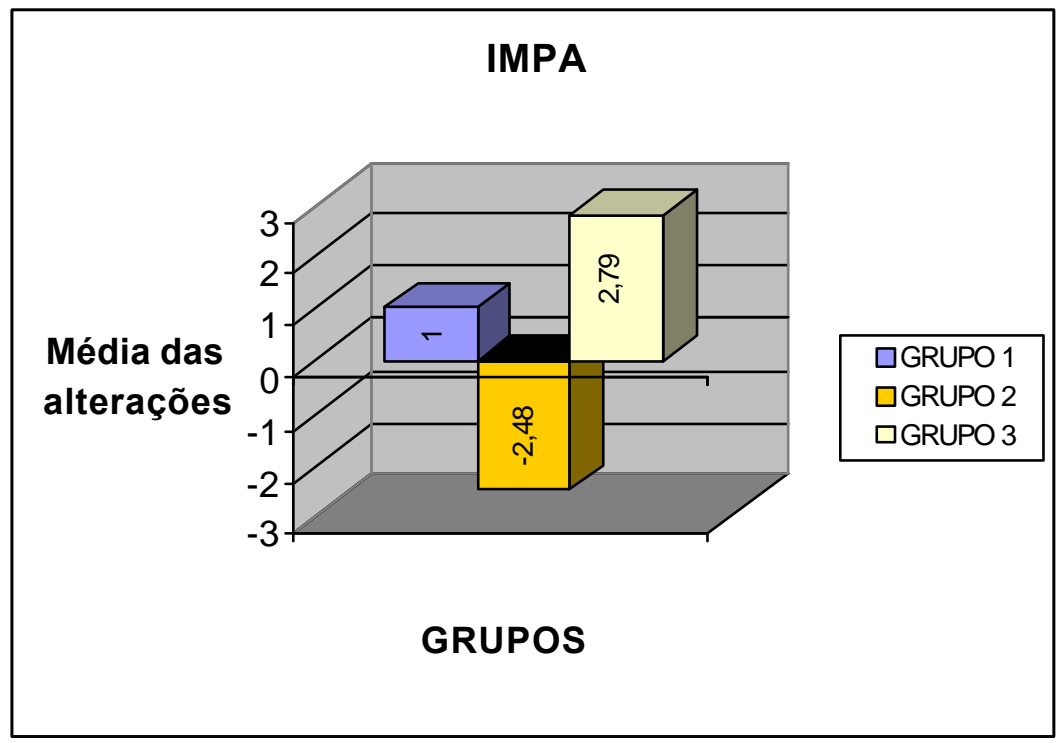

FIGURA 85- Alterações do ângulo IMPA nos três grupos.

Quanto ao posicionamento vertical dos primeiros molares inferiores, os três grupos experimentaram um aumento da medida $\overline{6}$-GoMe, denotando uma extrusão destes dentes, e apresentando diferença estatisticamente significante somente entre os grupos tratados e o controle. De forma similar, ALMEIDA ${ }^{3}$, ALMEIDA; HENRIQUES; URSF', ALMEIDA et al. ${ }^{7}$, BISHARA; ZIAJA ${ }^{25}$, BOLMGREN; MOSHIRP2, FREITAS ${ }^{57}$, HARVOLD; VARGERVIK ${ }^{64}$, NELSON; HARKNESS; HERBISON $^{115}$, TSAMTSOURIS; VEDRENNE ${ }^{150}$, afirmaram que o ativador/bionator propiciou a extrusão dos dentes póstero-inferiores.

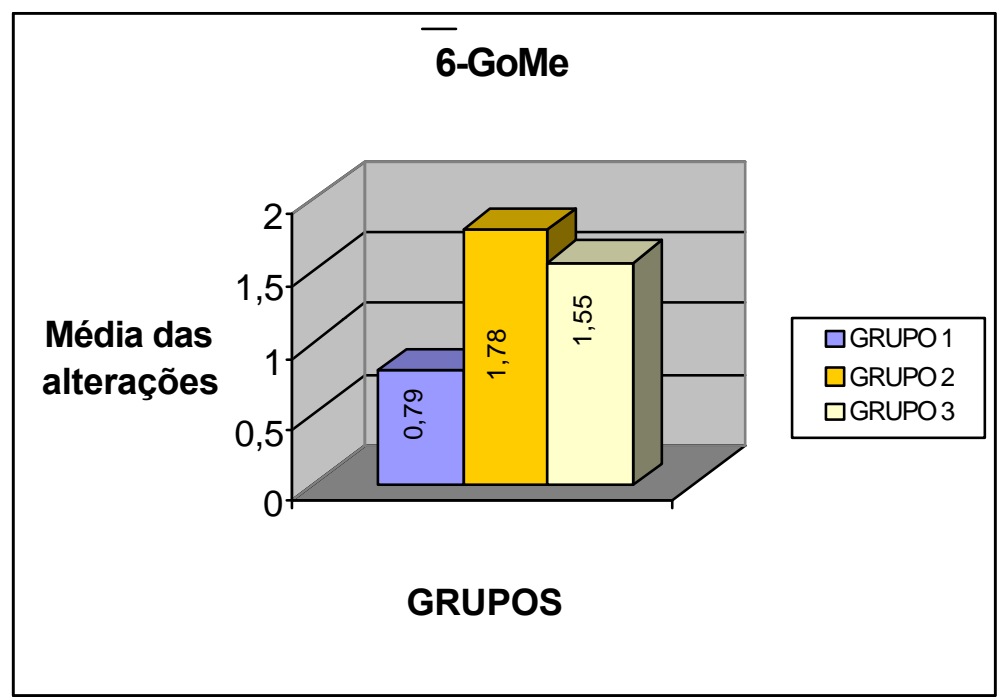

FIGURA 86- Alterações da medida $\overline{6}$-GoMe nos três grupos. 
Analisando o deslocamento horizontal dos primeiros molares inferiores pela medida $\overline{6}$-FHP observou-se um comportamento similar nos três grupos, demonstrando mesialização destes dentes. No entanto, foram verificadas diferenças estatisticamente significantes entre os grupos tratados e o controle, sendo que neste último a mesialização foi menor. Nos grupos tratados, esta mesialização considerada como efeito positivo para a correção da relação molar, foi maior no grupo 2 cerca de $1,64 \mathrm{~mm}$ e no grupo 3 aproximadamente 2,22mm em relação ao grupo não tratado. Este resultado corrobora com as pesquisas de PANCHERZ ${ }^{121}$, SCHULHOF; ENGEL ${ }^{144}$ e TSAMTSOURIS; VEDRENNE ${ }^{150}$.

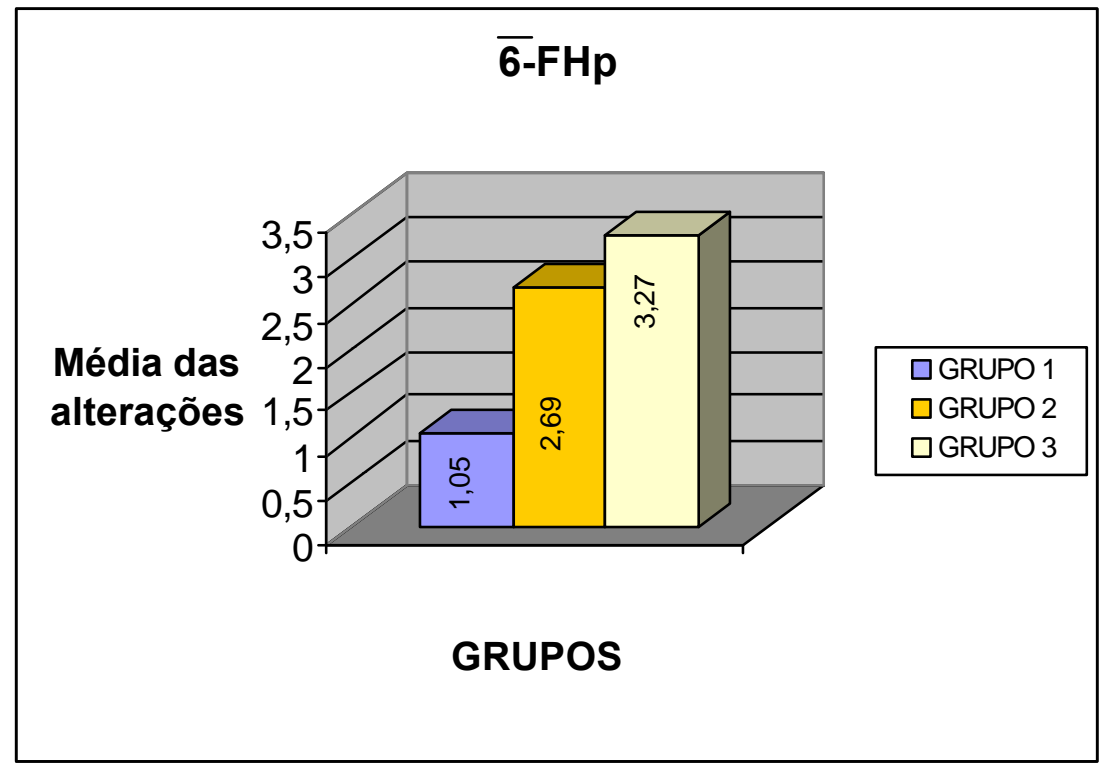

FIGURA 87- Alterações da medida $\overline{6}$-FHp nos três grupos.

Um dos mecanismos responsáveis pela correção da má oclusão de Classe II, $1^{\text {a }}$ divisão fundamenta-se no princípio da erupção diferencial de Harvold que consiste na inibição da irrupção dos molares superiores no sentido ântero-inferior e promoção da extrusão e mesialização dos dentes póstero-inferiores. Esta assertiva refere-se aos aparelhos ortopédicos funcionais, no entanto ambos os aparelhos avaliados neste estudo produziram tais efeitos, principalmente no arco inferior. 


\subsubsection{Perfil tegumentar (Figuras 88, 89 e 90)}

Para verificar se o tratamento da Classe II, $1^{\text {a }}$ divisão com os aparelhos ortopédicos referenciados neste estudo contribuíram para a obtenção de um perfil tegumentar mais harmonioso, foram avaliadas três grandezas cefalométricas: o ângulo nasolabial (ANL) e a quantidade de protrusão dos lábios superior (Ls-Pog'Sn) e inferior (Li-Pog'Sn).

Observou-se que todos os grupos apresentavam, inicialmente, uma protrusão dos lábios superiores e inferiores, com exceção do grupo controle que apresentou lábio inferior suavemente retruído. O tratamento com o AEB conjugado influenciou o posicionamento dos lábios, diminuindo a protrusão até os níveis de normalização tanto do lábio superior como do inferior. Do mesmo modo, o grupo tratado com o Bionator também experimentou uma diminuição da protrusão labial superior e um discreto aumento da protrusão labial inferior, no entanto os lábios superiores e inferiores continuaram protrusos neste grupo. No grupo controle praticamente não foram verificadas alterações no posicionamento labial, não obstante notourse um discreto aumento nas medidas Ls-Pog'Sn e Li-Pog'Sn. Este comportamento distinto entre os grupos mostrou diferença estatisticamente significante em relação ao posicionamento do lábio superior. Em relação ao lábio inferior, apenas o grupo 2 mostrourse diferente dos demais, e essa diferença alcançou significância estatística.

As alterações no posicionamento labial geralmente relacionam-se com as alterações na posição dos dentes anteriores. Assim, torna-se evidente que os lábios superior e inferior retruíram acompanhando o movimento para lingual dos incisivos superiores e inferiores no grupo tratado com o AEB conjugado. Os mesmos efeitos foram identificados no grupo 3 e no controle, onde os lábios movimentaram-se de acordo com a alteração da posição dos incisivos. Concordando com estes resultados, $\mathrm{ALMEIDA}^{3}$ constatou que o lábio superior sofreu uma retração, acompanhando as alterações desenvolvidas pelos incisivos, que por sua vez inclinaram-se para lingual com o uso do Bionator. Outro estudo (LANGE et al. ${ }^{94}$ ) 
demonstrou que o lábio superior não sofreu efeito significante com o uso do Bionator.

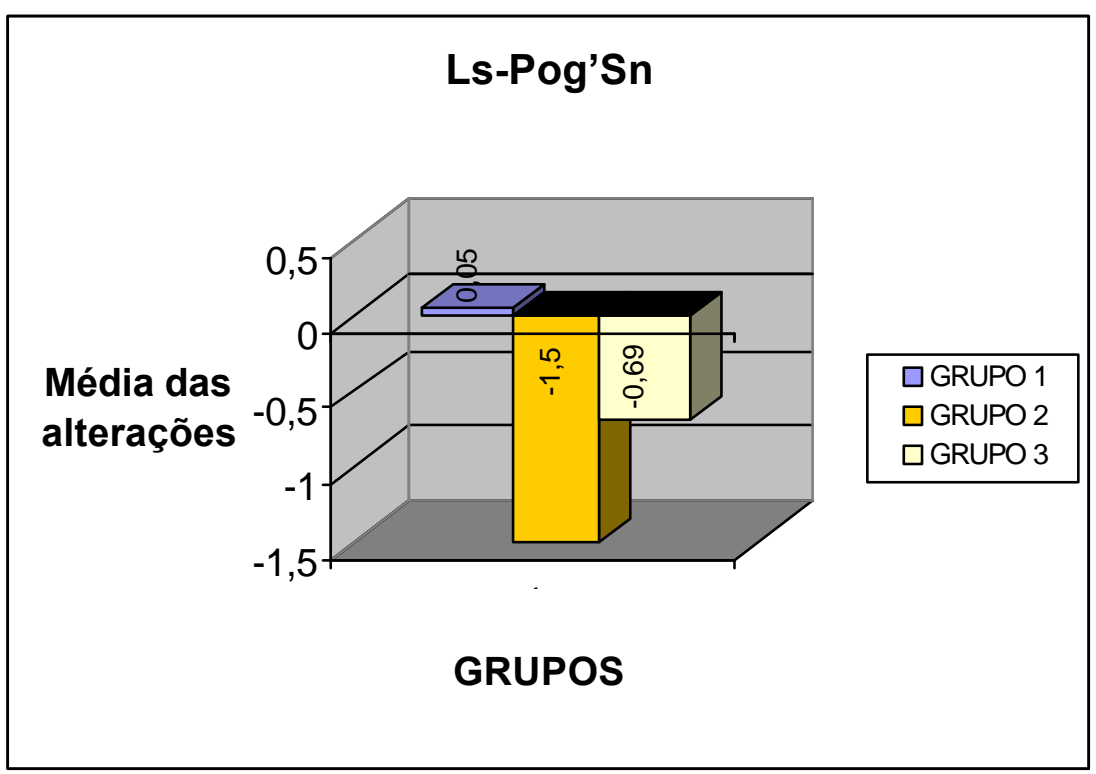

FIGURA 88- Alterações do lábio superior (Ls-Pog'Sn) nos três grupos.

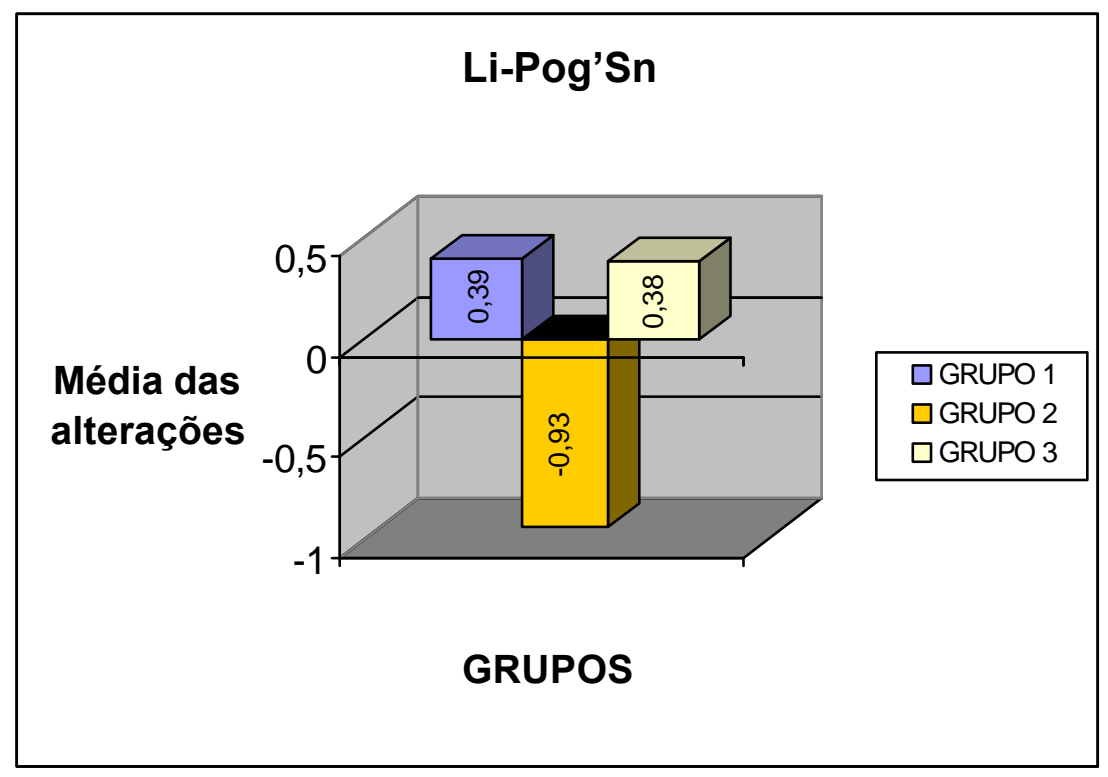

FIGURA 89- Alterações do lábio inferior (Li-Pog’Sn) nos três grupos. 
Avaliando o ângulo nasolabial, não foi possível notar diferenças estatisticamente significantes entre os grupos. Os grupos 1 e 2 mostraram um discreto aumento do ângulo nasolabial, enquanto o grupo 3 experimentou uma diminuição desta grandeza, ambos sem diferença estatística. Neste estudo não houve diferença significante entre os grupos tratados e o grupo controle, mostrando que os aparelhos ortopédicos não afetam substancialmente o ângulo nasolabial, como reportado por ALMEIDA ${ }^{3}$, LANGE et al. ${ }^{94}$.

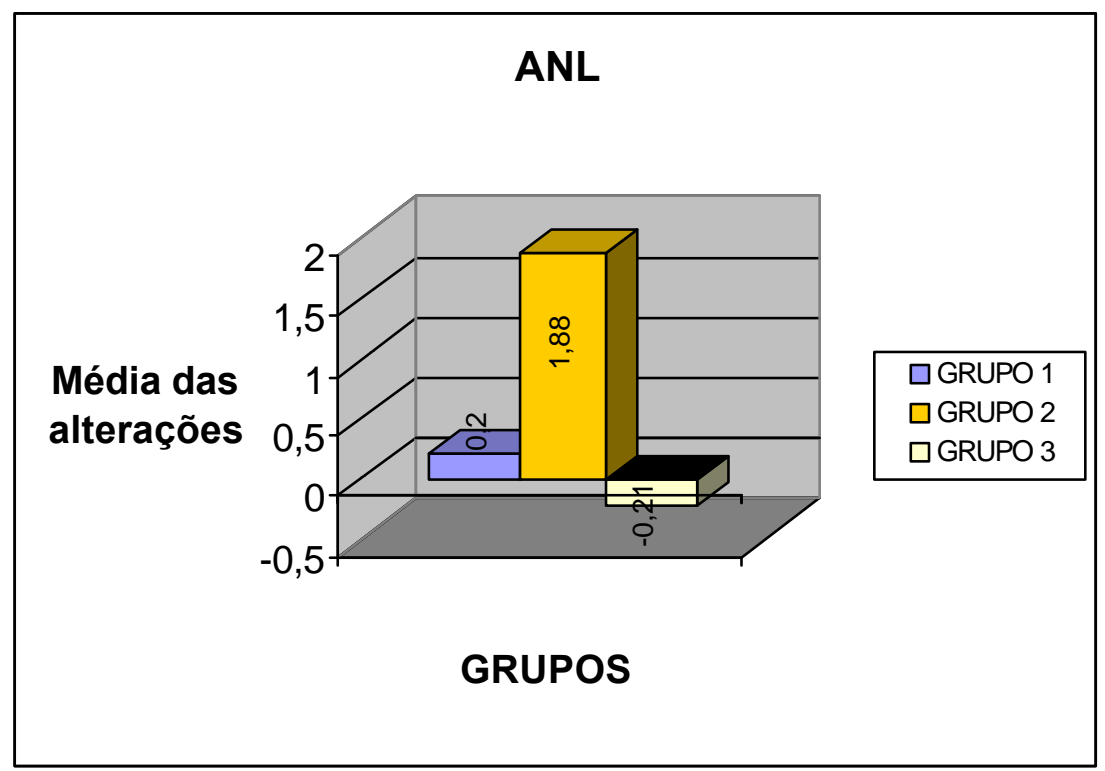

FIGURA 90- Alterações do ângulo nasolabial nos três grupos.

Como conclusão deste tópico, pode-se assegurar que os aparelhos estudados proporcionaram a retração do lábio superior, melhorando conseqüentemente o padrão do perfil tegumentar dos jovens com Classe II, $1^{\underline{a}}$ divisão que normalmente apresentam uma deficiência postural dos lábios, com vestibuloversão dos incisivos superiores. Com relação ao lábio inferior apenas o AEB conjugado produziu retrusão deste. É importante salientar que o posicionamento sagital dos lábios associou-se com a posição final dos incisivos. 


\subsection{Considerações Finais}

Contemporaneamente, a Ortodontia cerca-se de inúmeros aparelhos ortopédicos para a correção da má oclusão de Classe II, 1a divisão, no entanto ainda há controvérsia quanto aos efeitos dentoesqueléticos e tegumentares e em relação ao mecanismo de ação das diferentes abordagens terapêuticas. Os critérios de escolha do aparelho a ser instituído baseiam-se quase sempre em evidência clínica, científica e na morfologia craniofacial, e a definição do plano de tratamento se estabelece por meio das análises cefalométricas e facial.

É consenso entre os estudos que os dentes e as bases ósseas apicais podem ser efetivamente movimentadas e reposicionadas com aparelhos ortopédicos com a finalidade de corrigir, ou pelo menos amenizar, a discrepância dentoesquelética em uma fase de crescimento facial ativo. Quanto à alteração no perfil facial, os trabalhos científicos mostram-se menos conclusivos, aludindo resultados não tão promissores no restabelecimento da estética facial. Contudo, ainda há dúvida se diferentes aparelhos ortopédicos produzem efeitos distintos sobre as estruturas ósseas, dentárias e tecidos moles.

$\mathrm{Na}$ tentativa de elucidar estes questionamentos executourse esta pesquisa e a seguir serão apresentados o sumário dos efeitos suscitados pelas duas modalidades de tratamento ortopédico avaliadas.

A análise dos resultados mostrou que o tratamento da má oclusão de Classe II, 1ํㅡ divisão com o AEB conjugado e com o Bionator resultou de efeitos específicos e inerentes a cada aparelho. No entanto, ambos protocolos de tratamento propiciaram alterações esqueléticas, dentárias e tegumentares relevantes para a correção desta má oclusão. Esta afirmação torna-se evidente comparando-se os grupos experimentais ao grupo controle não tratado. 
Os efeitos do crescimento e desenvolvimento craniofacial nos pacientes portadores de má oclusão de Classe II, $1^{\underline{a}}$ divisão que não receberam tratamento (grupo 1) mantiveram-se constantes, perpetuando a má oclusão. Em relação às bases ósseas observou-se, neste grupo, uma suave porém não significante diminuição do grau de protrusão maxilar e mandibular. Assim, o relacionamento maxilomandibular manteve-se deficiente, apresentando uma redução (ANB) de apenas $0,45^{\circ}$, não considerada, clinicamente e nem estatisticamente, significante. $O$ padrão de crescimento apresentou pequenas alterações, não relevantes, como a diminuição do plano mandibular em relação à base do crânio (SN.GoGn), um suave aumento do plano palatino e um maior aumento das alturas facial ântero-inferior (AFAl) e posterior total (S-Go). Os incisivos superiores e inferiores inclinaram-se ainda mais para vestibular e protruíram nas respectivas bases ósseas, preservando o trespasse horizontal aumentado. Os molares superiores extruíram e mesializaram mais que nos grupos tratados, e com os molares inferiores ocorreu exatamente 0 contrário, menor extrusão e menor mesialização em relação aos outros grupos. Em relação ao perfil facial não se constatou alterações no ângulo nasolabial e nem na posição dos lábios superiores e inferiores.

O tratamento com o AEB conjugado proporcionou alterações esqueléticas tanto na maxila como na mandíbula e alterações dentárias. Houve restrição significativa do desenvolvimento maxilar para anterior, diminuindo as medidas SNA e Nperp-A e menor aumento do comprimento efetivo da maxila, quando comparado ao grupo controle. A protrusão da mandíbula aumentou (0,46 graus) aproximadamente quatro vezes mais que no grupo controle (-0,18 graus), contudo os grupos não foram considerados estatisticamente diferentes. As dimensões mandibulares aumentaram, sem denotar significância estatística, porém os efeitos deste aparelho no componente mandibular parecem contribuir clinicamente para a correção da má oclusão de Classe II, 1a divisão, pois não dá para omitir que o deslocamento da mandíbula para anterior foi estimulado em cerca de $70 \%$ quando se compara os valores médios de Co-Gn do grupo controle $(3,23 \mathrm{~mm})$ com este grupo tratado $(5,29 \mathrm{~mm})$. A relação maxilomandibular foi significantemente melhorada. Não se observou efeitos estatisticamente significantes no padrão de crescimento 
craniofacial, entretanto, houve uma rotação do plano mandibular no sentido antihorário o que é altamente favorável para a correção da má oclusão de Classe II, 1a divisão. Os incisivos superiores inclinaram-se para lingual e foram retruídos nas bases apicais. Conseqüentemente, os incisivos inferiores também inclinaram-se para lingual e retruíram, acompanhando o movimento dos incisivos superiores Os molares superiores distalizaram e os inferiores deslocaram-se para mesial, contribuindo para a correção da relação molar. Constatourse também um desenvolvimento vertical dos molares superiores e inferiores caracterizando extrusão destes dentes sem influência nas alturas faciais ântero-inferior e posterior. No perfil tegumentar as alterações restringiram-se ao posicionamento dos lábios que foram retruídos durante o tratamento.

Os efeitos produzidos pelo Bionator foram mais evidentes nos componentes mandibular e dentário. O grau de protrusão maxilar (SNA e Nperp-A) diminuiu suavemente e sem significância. A variação do comprimento efetivo da maxila (CoA) apresentou o menor valor médio entre os três grupos: 0,81 mm, 1,72mm (AEB conjugado) e 2,33 $\mathrm{mm}$ (controle) sugerindo uma restrição da maxila, no entanto, deve-se destacar que esta medida é influenciada pelo ponto condílio o qual deslocase para anterior devido à remodelação da cavidade glenóide em conseqüência do avanço mandibular alusivo ao mecanismo de ação do Bionator, assim, o efeito restritivo sobre a maxila é considerado uma interpretação inadequada. Um significante aumento da protrusão mandibular (1,23 graus) em relação aos dois outros grupos foi observado. As dimensões mandibulares aumentadas também foram afetadas pelo tratamento com o Bionator, no entanto assim como ocorreu no grupo tratado com o AEB conjugado, as diferenças entre os grupos tratados e o grupo controle não foram estatisticamente significantes. Porém, ressalta-se que o valor médio da variação do comprimento efetivo da mandíbula com o Bionator $(4,15 \mathrm{~mm})$ foi $30 \%$ maior que no grupo controle $(3,23 \mathrm{~mm})$, não podendo desconsiderar esta alteração clinicamente significante. Conseqüentemente às alterações nas bases ósseas, ocorreu uma melhora significativa da relação maxilomandibular e da convexidade facial. O padrão de crescimento manteve-se estável, assim como as alturas faciais, que não mostraram alteração significante, 
não obstante os molares superiores e inferiores tenham extruído e mesializado. Os incisivos superiores inclinaram para lingual e retruíram, enquanto que os inferiores vestibularizaram e protruíram na base óssea, efeitos estes que contribuem sobremaneira para a correção da Classe II. O perfil facial mostrou poucas alterações restritas, apenas à discreta retrusão do lábio superior.

Em resposta aos questionamentos destacados anteriormente, verificourse que diferentes abordagens terapêuticas podem corrigir uma mesma má oclusão, produzindo efeitos distintos sobre as estruturas ósseas, os dentes e os tecidos moles. Comparando um aparelho ortopédico mecânico com um ortopédico funcional foi possível identificar algumas características distintas, referentes ao modo de ação de cada aparelho. Ambos os protocolos de tratamento mostraram-se eficazes na correção da má oclusão de Classe II, 1a divisão promovendo grandes alterações dentárias e menores efeitos esqueléticos, de acordo com outros estudos como o de BISHARA; ZIAJA ${ }^{25}$ que verificaram que a combinação dos efeitos dentoalveolares varia em torno de 60 a $70 \%$ e dos ortopédicos por volta de 30 a $40 \%$.

Basicamente a diferença entre os efeitos esqueléticos promovidos pelos aparelhos avaliados residiu na restrição do componente maxilar pelo $A E B$ conjugado, maior efeito no componente mandibular com o Bionator e controle vertical do crescimento facial obtido com o AEB conjugado. Em relação aos dentes superiores, o AEB conjugado distalizou os molares, enquanto que o Bionator praticamente não influenciou este posicionamento e ambos promoveram discreta extrusão destes dentes. Os incisivos superiores foram inclinados para lingual significantemente com ambos os aparelhos, o que pode ser considerado favorável

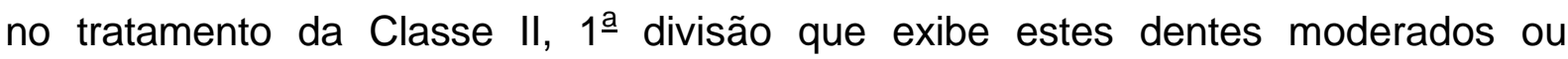
severamente inclinados para vestibular. Diante de uma moderada vestibularização dos incisivos superiores pode-se optar pelo Bionator, enquanto em casos com severa inclinação para vestibular o AEB conjugado responde melhor, mas também promove retrusão, às vezes excessiva dos lábios superiores abrindo o ângulo nasolabial. Os incisivos inferiores vestibularizam com a terapia funcional do Bionator, se isto for desejável para o caso, ponto positivo para esta abordagem, do contrário 
pode-se indicar o AEB conjugado que inclina estes dentes para lingual. Os molares inferiores parecem ser igualmente afetados por ambos aparelhos, que produzem extrusão e mesialização destes dentes.

As alterações suscitadas pelo AEB conjugado, neste estudo, contrariaram diversas pesquisas que relacionaram os efeitos deste aparelho somente ao componente maxilar. De acordo com KEELING et al. ${ }^{88}$, WHEELER et al. ${ }^{164}$ e YOU et al. ${ }^{167}$ um aparelho que promova desoclusão posterior, associado a uma força extrabucal é capaz de restringir o crescimento anterior da maxila e liberar o crescimento mandibular, produzindo efeitos semelhantes àqueles angariados com os aparelhos que avançam a mandíbula. Segundo a afirmação de MARTINS ${ }^{105}$, a ação de um AEB sobre a face média, isoladamente, permite que a mandíbula complete seu crescimento normal, contribuindo na correção da discrepância ântero-posterior, efeito este confirmado nesta pesquisa.

Deve-se considerar imperativa a análise facial no planejamento ortopédico, assim, diante de diferentes morfologias craniofaciais é sensato utilizar diferentes abordagens terapêuticas. Portanto, nos casos de má oclusão de Classe II, 1a divisão com protrusão maxilar e/ou dentoalveolar superior, melhores resultados seriam obtidos com o uso isolado do AEB ou do AEB conjugado nos casos com protrusão dentoalveolar e deficiência mandibular. Para os casos somente com deficiência mandibular pode-se utilizar um aparelho ortopédico que avança a mandíbula como o Bionator.

Diante do exposto e à luz de um estudo retrospectivo, parece sensato ressaltar que toda extrapolação dos resultados desta pesquisa para a população em geral deve ser realizada com ressalvas considerando as limitações da metodologia empregada. 


$$
7 \text { CONCLUSÕES }
$$




\section{CONCLUSÕES}

Em relação às alterações suscitadas pelo tratamento com os aparelhos estudados e de acordo com a proposição, metodologia e resultados deste estudo pode-se inferir:

\subsection{Componente maxilar:}

O deslocamento anterior da maxila foi restringido significantemente pelo tratamento com o AEB conjugado. Diferentemente, o tratamento com o Bionator não propiciou alterações significantes no desenvolvimento maxilar.

\subsection{Componente mandibular:}

O Bionator promoveu um aumento significante na protrusão mandibular, o AEB conjugado mostrou efeitos menos evidentes enquanto o grupo controle apresentou uma diminuição do grau de protrusão da mandíbula.

As dimensões mandibulares aumentaram sensivelmente nos grupos tratados, porém estes efeitos não foram considerados estatiscamente significantes. No entanto, cabe ressaltar a relevância clínica destes resultados.

\subsection{Relação maxilomandibular:}

Os aparelhos avaliados propiciaram uma melhora significante na relação maxilomandibular e na convexidade facial, com diminuição dos ângulos ANB e NAP. 


\subsection{Relação vertical:}

Nenhum dos aparelhos produziu alterações significantes no padrão de crescimento craniofacial. Nos grupos 1 e 2 verificou-se uma rotação do plano mandibular no sentido anti-horário. O posicionamento vertical da maxila (SN.PP) também não se alterou. A altura facial ântero-inferior (AFAI) e a altura facial posterior não mostraram alterações significantes, não se constatando os propagados efeitos deletérios dos aparelhos ortopédicos no aumento destas variáveis.

\subsection{Componente dentoalveolar:}

Ambos aparelhos provocaram inclinação para lingual e retrusão dos incisivos superiores, porém os efeitos do AEB conjugado foram significantemente mais intensos.

Os primeiros molares superiores não extruíram significantemente, mantendo estáveis suas posições no sentido vertical. No sentido ântero-posterior verificourse uma distalização destes dentes no grupo tratado com o AEB conjugado, enquanto nos grupos 3 (Bionator) e 1 (controle) houve mesialização.

Os incisivos inferiores foram afetados de maneira distinta pelos aparelhos. No grupo tratado com o AEB conjugado, os incisivos lingualizaram e retruíram enquanto que o grupo tratado com o Bionator apresentou uma inclinação para vestibular e protrusão destes dentes.

Os primeiros molares inferiores apresentaram um deslocamento no sentido vertical (extrusão) e horizontal (mesialização) significantemente maior nos grupos tratados. 


\subsection{Perfil tegumentar:}

O ângulo nasolabial não foi afetado pelo tratamento não obstante tenha apresentado um comportamento distinto entre os grupos.

O tratamento com o AEB conjugado influenciou o posicionamento dos lábios, diminuindo a protrusão, até os níveis de normalidade, tanto do lábio superior como do inferior. $O$ grupo tratado com o Bionator também experimentou uma diminuição da protrusão labial superior e um discreto aumento da protrusão labial inferior. 


\section{REFERÊNCIAS}

\section{BIBLIOGRÁFICAS}




\section{REFERÊNCIAS BIBLIOGRÁFICAS **}

1. AHN, S.J.; KIM, J.T.; NAHM, D.S. Cephalometric markers to consider in the treatment of class II division 1 malocclusion with the bionator. Amer $\mathbf{J}$ Orthodont Dentofac Orthop, v.119, n.6, p.578-86, June 2001.

2. ALARASHI, M. et al. Morphometric analysis of the transverse dentoskeletal features of Class II malocclusion in the mixed dentition. Angle Orthodont, v.73, n.1, p.21-5, Jan. 2003.

3. ALMEIDA, M.R. Avaliação cefalométrica comparativa da interceptação da má oclusão de Classe II, $1^{\text {a }}$ divisão utilizando o aparelho de Fränkel e o Bionator de Balters. Bauru, 2000. 241p. Tese (Doutorado) - Faculdade de Odontologia de Bauru, Universidade de São Paulo.

4. ALMEIDA, M.R.; HENRIQUES, J.F.C.; URSI, W.J.S. Comparative study of the Fränkel (FR-2) and bionator appliances in the treatment of Class II malocclusion. Amer J Orthodont Dentofac Orthop, v.121, n.5, p.45866, May 2002.

5. ALMEIDA, M.R. et al. Estudo cefalométrico comparativo, da ação de dois tipos de aparelhos ortopédicos, sobre as estruturas dentoesqueléticas e tegumentares de jovens de ambos os sexos com más oclusões de Classe II, $1^{\text {a }}$ divisão. Ortodontia, v.31, n.2, p.32-52, mai./jun./jul./ago. 1998.

\footnotetext{
* NBR 10719 da ABNT (Associação Brasileira de Normas Técnicas)

** Normas recomendadas para uso no âmbito da Universidade de São Paulo, com base no diocumento "Referências Bibliográficas: exemplos", emanados do Conselho Supervisor do Sistema Integrado de Bibliotecas da USP, em reunião de 20 de setembro de 1990.
} 
6. ALMEIDA, M.R. et al. O tratamento da Classe II, divisão 1 com o uso do AEB conjugado e aparelho fixo. Rev Clin Ortodon Dental Press, v.1, n.3, p.63-71, jun./jul. 2002.

7. ALMEIDA, M.R. et al. Treatment effects produced by the Bionator appliance. Comparision with an untreated Class II sample. Europ J Orthodont, (in press- 2003).

8. ALMEIDA, R.R. et al. Utilização do AEB conjugado na interceptação da má-oclusão de Classe II, 1a divisão. Rev APCD, v.56, n.4, p.308-12, jul./ago. 2002.

9. ALTEMUS, L.A. Horizontal and vertical dentofacial relationships in normal and Class II, division 1 malocclusion in girls 11-15 years. Angle Orthodont, v.25, n.3, p.120-37, July 1955.

10. AltUNA, G.; NIEGEL, S. Bionators in Class II treatment. $\mathbf{J}$ clin Orthodont, v.19, n.3, p.185-91, Mar. 1985.

11. ANDERSON, G.M. On the diagnosis and treatment of "distocclusion". Amer J Orthod Oral Surg, v.32, n.1, p.88-94, Jan. 1946.

12. ANDERSON, D.L.; POPOVICH, F. Lower cranial height vs craniofacial dimension in Angle Class II malocclusion. Angle Orthodont, v.53, n.3, p.253-60, July 1983.

13. ANGLE, E.H. Classification of malocclusion. Dent Cosmos, v.41, n.3, p.248-64, 350-7, Mar. 1899.

14. ANGLE, E.H. Malocclusion of the teeth. 7.ed., Philadelphia, S.S. White, 1907. 
15. ASCHER, F. The bionator. In: GRABER, T.M.; NEUMMAN, B. Removable

Orthodontic Appliances. Philadelphia, W.B. Saunders, 1977. p.22946.

16. BACCETTI, T. et al. Early dentofacial features of Class II malocclusion: a longitudinal study from the deciduous through the mixed dentition. Amer J Orthod Dentofac Orthop, v.111, n.5, p.502-9, May 1997.

17. BAKER, J.N. apud NELSON, B.G ${ }^{114}$. What does extraoral anchorage accomplish? Amer J Orthodont, v.38, n.6, p.422-34, June 1952.

18. BASS, N.M. Dento-facial orthopaedics in the correction of Class II malocclusion. Brit J Orthodont, v.9, n.1, p.3-31, Jan. 1982.

19. BASS, N.M. Orthopedic coordination of dentofacial development in skeletal Class II malocclusion in conjuction with edgewise therapy. Part I Amer J Orthodont, v.84, n.5, p.361-83, Nov. 1983.

20. BASS, N.M. Orthopedic coordination of dentofacial development in skeletal Class II malocclusion in conjuction with edgewise therapy. Part II. Amer J Orthodont, v.84, n.6, p.466-90, Dec. 1983.

21. BAUMRIND, S.; FRANTZ, R.C. The reliability of head film measurements. 1. Landmark identification. Amer J Orthodont, v.60, n.2, p.111-27, Aug. 1971.

22. BAUMRIND, S.; MILLER, D.; MOLTHEN, R. The reliability of head film measurements. Tracing superimposition. Amer J Orthodont, v.70, n.6, p.617-44, Dec. 1976.

23. BERTOZ, F.A. et. al. Características cefalométricas de pacientes com má oclusão Classe II. Rev APEO, v.1, n.1, p.35-41, jan./mar. 2003. 
24. BISHARA, S.E. Mandibular changes in persons with untreated and treated Class II division 1 malocclusion. Amer J Orthodont Dentofac Orthop, v.113, n.6, p.661-73, June 1998.

25. BISHARA, S.E.; ZIAJA, R.R. Functional appliances: a review. Amer J Orthodont Dentofac Orthop, v.95, n.3, p.250-8, Mar. 1989.

26. BISHARA, S.E. et al. Changes in dentofacial structures in untreated Class II division 1 and normal subjects: a longitudinal study. Angle Orthodont, v.67, n.1, p.55-66, Mar. 1997.

27. BOLMGREN, G.A.; MOSHIRI, F. Bionator treatment in Class II, division 1. Angle Orthodont, v.56, n.3, p.255-62, July 1986.

28. BRANDÃO, A.M.B.; DOMÍNGUEZ-RODRIGUEZ, G.C.; CAPELOZZA FILHO, L. Avaliação comparativa entre as características da má oclusão Classe II, divisão 1 obtidas pela cefalometria e análise facial subjetiva. Rev Dental Press Ortod Ortop Fac, v.6, n.2, p.33-40, mar./abr. 2001.

29. BRODIE, A.G. Cephalometric appraisal of orthodontic results. Angle Orthodont, v.8, n.4, p.261-5, Oct. 1938.

30. BURSTONE, C.J. Lip posture and its significance in treatment planning. Amer J Orthodont, v.53, n.4, p.262-84, Apr. 1967.

31. BUSCHANG, P.H.; MARTINS, J. Childhood and adolescent changes of skeletal relationship. Angle Orthodont, v.68, n.3, p.199-208, June 1998. 
32. BUSCHANG, P.H. et al. Mathematical models of longitudinal mandibular growth for children with normal and untreated Class II, division 1 malocclusion. Europ J Orthodont, v.10, n.3, p.227-34, Aug. 1988.

33. CALDWELL, S.F.; HYMAS, A.; TIMM, T.A. Maxillary traction splint: a cephalometric evaluation. Amer J Orthodont, v.85, n.5, p.376-84, May 1984.

34. CARTER, N.E. Dentofacial changes in untreated Class II Division 1 subjects. Brit J Orthod, v.14, n.4, p.225-34, Nov. 1987.

35. CELLIER, F. apud NELSON, B.G. ${ }^{114}$ What does extraoral anchorage accomplish? Amer J Orthodont, v.38, n.6, p.422-34, June 1952.

36. CHANG, $\mathrm{H}$. et al. Effects of activator treatment on Class II, division 1 malocclusion. J Clin Orthodont, v.23, n.8, p.560-3, Aug. 1989.

37. CHEN, J.Y.; WILL, L.A.; NIEDERMAN, R. Analysis of efficacy of functional appliances on mandibular growth. Amer J Orthodont Dentofac Orthop, v.122, n.5, p.470-6, Nov. 2002.

38. COURTNEY, M.; HARKNESS, M.; HERBISON, P. Maxillary and cranial base changes during treatment with functional appliances. Amer $\mathbf{J}$ Orthodont Dentofac Orthop, v.109, n.6, p.616-24, June 1996.

39. COUSINS, A.J.P.; CLARK, W.J. Extra-oral traction - theoretical considerations and the development of a removable appliance technique. Transactions of the British Society for the study of orthodontics. p.37-44, 1965. apud FERGUSON, J.W ${ }^{53}$. A new method of attaching headgear to upper removable appliances. Brit $\mathbf{J}$ Orthodont, v.10, n.1, p.48-9, Jan. 1983. 
40. CRAIG, C.E. The skeletal patterns characteristic of class I and class II, division I malocclusions in norma lateralis. Angle Orthodont, v.21, n.1, p.44-56, Jan. 1951.

41. CURA, N. et al. Orthodontic and orthopedic effects of activador, activatorHG combination, and bass appliances: a comparative study. Amer J Orthodont Dentofac Orthop, v.110, n.1, p.36-45, July 1996.

42. DAHLBERG, G. Statistical methods for medical and biological students. New York, Interscience, 1940.

43. DE CASTRO, N. The challenge of Class II, division 1 malocclusion. Amer J Orthodont, v.46, n.11, p.829-33, Nov. 1960.

44. DE VINCENZO, J.P. Changes in mandibular lenght before, during, and after successful orthopedic correction of Class II malocclusions, using a functional appliance. Amer J Orthodont Dentofac Orthop, v.99, n.3, p.241-57, Mar. 1991.

45. DERRINGER, K. A cephalometric study to compare the effects of cervical traction and Andresen therapy in the treatment of Class II division 1 malocclusion. Part 1-Skeletal changes. Brit J Orthodont, v.17, n.1, p.33-46, Feb. 1990.

46. DIBBETS, J.M.H. Morphological associations between the Angle classes. Europ J Orthod, v.18, n.2, p.111-8, Apr. 1996.

47. DRAGE, K.J.; HUNT, N.P. Overjet relapse following functional appliance therapy. Brit J Orthodont, v.17, n.3, p.205-13, Aug. 1990.

48. DRELICH, R.C. A cephalometric study of untreated class II, division 1 malocclusion. Angle Orthodont, v.18, n.3-4, p.70-5, July/Oct. 1948. 
49. EIREW, H.L. The bionator. Brit J Orthodont, v.8, n.1, p.33-36, Jan. 1981.

50. FALTIN, C.O.; FALTIN JUNIOR, K. Bionator de Balters. Rev Dental Press Ortod Ortop Fac, v.3, n.6, p.70-95, nov./dez. 1998.

51. FALTIN JUNIOR, K. et. al. Long-term effectiveness and treatment timing for bionator therapy. Angle Orthodont, v.73, n.3, p.221-30, June 2003.

52. FARRAR, J.N. Orthodontics: an historical review of its and evolution. Saint Louis. Mosby, 1886. p.885.

53. FERGUSON, J.W. A new method of attaching headgear to upper removable appliances. Brit J Orthodont, v.10, n.1, p.48-9, Jan. 1983.

54. FISCHER, B. Treatment of Class II, division 1 (Angle). Variation and the "individuality hypothesis". Angle Orthodont, v.20, n.2, p.116-34, Apr. 1950.

55. FISK, G.V. et al. The morfology and physiology of distoclusion. Amer $\mathbf{J}$ Orthodont, v.39, p.3-12, Jan. 1953.

56. FOTIS, V. et al. Vertical control as an important ingredient in the treatment of severe sagital discrepancies. Amer J Orthodont, v.86, n.3, p.22432, Sept. 1984.

57. FREITAS, B.V. Estudo das alterações esqueléticas e dentárias em pacientes do sexo feminino com má-oclusão de Classe II, divisão 1, com retrognatismo mandibular, tratados por meio do Bionator de Balters, no período pré-puberal São Bernardo do Campo, 1996. 132p. Dissertação (Mestrado) - Faculdade de Ciências Biológicas e da Saúde do Instituto Metodista de Ensino Superior, da Federação de Escolas Superiores do ABC. 
58. FREITAS, M.R. Estudo analítico e comparativo do perfil facial mole, em adolescentes brasileiros, leucodermas, apresentando “Oclusão Normal”, com as diversas linhas estéticas preconizadas. Bauru, 1978. 69p. Dissertação (Mestrado) - Faculdade de Odontologia de Bauru, Universidade de São Paulo.

59. FREITAS, M.R. et. al. Prevalência das más oclusões em pacientes inscritos para tratamento ortodôntico na Faculdade de Odontologia de BaurutUSP. Rev Fac Odont Bauru, v.10, n.3, p.164-9, 2002.

60. FREUNTHALLER, P. Cephalometric observations in Class II, division I malocclusions treated with the activator. Angle Orthodont, v.37, n.1, p.18-25, Jan. 1967.

61. GHAFARI, J.; KING, G.J.; TULLOCH, J.F.C. Early treatment of Class II, division 1 malocclusion-comparison of alternative treatment modalities. Clin Orthod Res, v.1, n.2, p.107-17, Nov. 1998.

62. GILMORE, W.A. Morphology of the adult mandible in Class II, division 1 malocclusion and in excellent oclusion. Angle Orthodont, v.20, n.3, p.137-46, July 1950.

63. GURGEL, J.A.; ALMEIDA, R.R.; PINZAN, A. Avaliação œmparativa das dimensões maxilomandibulares entre jovens do sexo masculino, com má oclusão de Classe II, 1a divisão, não tratados e com oclusão normal. Rev Dental Press Ortod Ortop Fac, v.5, n.2, p.20-8, mar./abr. 2000.

64. HARVOLD, E.P.; VARGERVIK, K. Morphogenetic response to activator treatment. Amer J Orthodont, v.60, n.5, p.478-90, Nov. 1971. 
65. HASHIM, H.A. Analysis of activator treatment changes. Austr Orthod J, v.12, n.2, p.100-4, Oct. 1991.

66. HELLMAN, M. Studies on the etiology of Angle`s Class II malocclusal manifestations. Int J Orthodont, v.8, p.129-59, 1922.

67. HENRIQUES, J.F.C. Estudo cefalométrico comparativo, de três tipos de ancoragem extrabucal, sobre as estruturas dentoesqueléticas, em pacientes com classe II, 1a divisão. Bauru, 1993. 166p. Tese (Livre Docência) - Faculdade de Odontologia de Bauru, Unversidade de São Paulo.

68. HENRIQUES, J.F.C.; FREITAS, M.R.; SANTOS PINTO, C.C.M. Correção de uma má oclusão de classe II, divisão 1, com protrusão maxilar, utilizando o arco facial conjugado a um aparelho removível (AEB conjugado). Ortodontia, v.24, n.3, p.14-8, set./dez. 1991.

69. HENRIQUES, J.F.C. et al. Modified maxillary splint for class II, division 1 treatment. J Clin Orthodont, v.25, n.4, p.239-45, Apr. 1991.

70. HENRIQUES, J.F.C. et al. Utilização do aparelho removível conjugado à ancoragem extrabucal para a correção da má oclusão de Classe II, $1^{\underline{a}}$ divisão, com sobremordida profunda. Rev Dental Press Ortod Ortop Fac, v.2, n.2, p.12-8, mar./abr., 1997.

71. HENRIQUES, J.F.C. et al. Tratamento da má oclusão de Classe II, $1^{a}$ divisão com retrusão mandibular utilizando o bionator previamente à aparelhagem fixa: relato de um caso clínico. Ortodontia, v.30, n.3, p.74-9, set./out./nov./dez. 1997. 
72. HENRIQUES, J.F.C. et al. Estudo longitudinal das características da má oclusão de Classe II, $1^{1}$ divisão sem tratamento, em jovens Brasileiros, Leucodermas, por um período médio de 3 anos. Rev Dental Press Ortod Ortop Fac, v.3, n.3, p.52-66, maio/jun. 1998.

73. HENRY, R.G. A classification of Class II, division 1 malocclusion. Angle Orthodont, v.27, n.2, p.83-92, Apr. 1957.

74. HOUSTON, W.J.B. The analysis of errors in orthodontic measurements. Amer J Orthodont Dentofac Orthop, v.83, n.5, p.382-90, May 1983.

75. ILLING, H.M.; MORRIS, D.O.; LEE, R.T. A prospective evaluation of bass, bionator and twin block appliances. Part I - the hard tissues. Europ $\mathbf{J}$ Orthodont, v.20, n.5, p.501-16, Oct. 1998.

76. JACOBS, T.; SAWAENGKIT, P. National Institute of Dental and Craniofacial Research efficacy trials of bionator Class II treatment: a review. Angle Orthodont, v.72, n.6, p.571-5, Dec. 2002.

77. JAKOBSSON, S.O.; PAULIN, G. The influence of activator treatment on skeletal growth in Angle Class II:1 cases. A roentgenocephalometric study. Europ J Orthodont, v.12, n.2, p.174-84, May 1990.

78. JANSON, I.A. A cephalometric study of the efficiency of the bionator. Trans Europ Orthod Soc, v.28, p.283-98, 1977.

79. JANSON, I.A. Skelettale und dentoalveoläre Veränderungen durch die Bionatorbehandlung in der vorpubetären und pubertären wachstumszeit. Fortschr Kieferorthop, v.39, n.1, p.62-76, Jan. 1978.

80. JANSON, I.R.; NOACHTAR, R. Functional appliance therapy with the bionator. Sem Orthod, v.4, n.1, p.33-45, 1998. 
81. JANSON, M.; HASUND, A. Functional problems in orthodontic patients out of retention. Europ J Orthodont, v.3, p.173-79, 1983.

82. JOFFE, L.; JACOBSON, A. The maxillary orthopedic splint. Amer J Orthodont, v.75, n.1, p.54-69, Jan. 1979.

83. JORGENSEN, S.E. Activators in orthodontic treatment: indications and advantages. Amer J Orthodont, v.65, n.3, p.260-9, Mar. 1974.

84. KALRA, V.; BURSTONE, C.J.; NANDA, R. Effects of a fixed magnetic appliance on the dentofacial complex. Amer J Orthodont Dentofac Orthop, v.95, n.6, p.467-78, June 1989.

85. KARLSEN, A.T. Craniofacial morphology in children with Angle Class II-1 malocclusion with and without deepbite. Angle Orthodont, v.64, n.6, p.437-46, Apr. 1994.

86. KATSAVRIAS, E.G.; HALAZONETIS, D.J. Intermaxillary forces during activator treatment. Amer J Orthodont Dentofac Orthop, v.115, n.2, p.133-7, Feb. 1999.

87. KEAN, M.R. Some aspects of facial depth in Class II, division 1 malocclusion. Angle Orthodont, v.28, n.1, p.1-11, Jan. 1958.

88. KEELING, S.D. et al. Anteroposterior skeletal and dental changes after early Class II treatment with bionators and headgear. Amer $\mathbf{J}$ Orthodont Dentofac Orthop, v.113, n.1, p.40-50, Jan. 1998.

89. KING, T.B. A cephalometric study of the positional relationship of the incisors and apical bases to each other in Class I and Class II, division 1. Amer J Orthodont, v.48, n.8, p.629-30, Aug. 1962. 
90. KINGSLEY, N.W. Orthodontics: an historical review of its origin and evolution. Saint Louis, Mosby, 1875, p. 492.

91. KLOCKE, A.; NANDA, R.S.; KAHL-NIEKE, B. Skeletal Class II patterns in the primary dentition. Amer J Orthodont Dentofac Orthop, v.121, n.6, p.596-601, June 2002.

92. KOROLUK, L.D.; TULLOCH, C.; PHILLLIPS, C. Incisor trauma and early treatment for Class II division 1 malocclusion. Amer J Orthodont Dentofac Orthop, v.123, n.2, p.117-26, Feb. 2003.

93. KROGMAN, W.M.; SASSOUNI, V. Syllabus in roentgenographic cephalometry. Philadelphia, College Offset, 1957.

94. LANGE, D.W. et al. Changes in soft tissue profile following treatment with the bionator. Angle Orthodont, v.65, n.6, p.423-30, Mar. 1995.

95. LIU, Y.T.; GRAVELY, J.F. The reliability of the "ortho grid" in cephalometric assessment. Brit J Orthodont, v.8, n.1, p.21-7, Feb. 1991.

96. LUNDSTRÖM, A.F. A contribution to the discussion concerning the nature of distoclusion. Dent Cosmos, v.27, n.10, p.956-69, Oct. 1925.

97. LUX, C.J. et al. Effects of early activator treatment in patients with Class II malocclusion evaluated by thin-plate spline analysis. Angle Orthodont, v.71, n.2, p.120-6, Apr. 2001.

98. MAIA, A. et al. Estudo cefalométrico das características da má oclusão de Classe II/1, em brasileiros da região nordeste, em fase de dentadura mista (parte 1). Ortodontia, v.31, n.2, p.53-68, maio/ago. 1998. 
99. MAJ, G.; LUZI, C.; LUCCHESE, P. A cephalometric appraisal of Class II and Class III malocclusions. Angle Orthodont, v.30, n.1, p.26-34, Jan. 1960.

100. MALTAGLIATI, L.A. Estudo comparativo das alterações dentoesqueléticas da má oclusão de Classe II, $1^{\text {a }}$ divisão de Angle, nos jovens sem tratamento e nos submetidos a dois tipos de aparelho ortodôntico. Bauru, 1997. 226p. Dissertação (Mestrado) Faculdade de Odontologia de Bauru, Universidade de São Paulo.

101. MAMANDRAS, A.H.; ALLEN, L.P. Mandibular response to orthodontic treatment with the bionator appliance. Amer J Orthodont Dentofac Orthop, v.97, n.2, p.113-20, Feb. 1990.

102. MARCONDES, A.R. Integration of certain variants as a determinant of facial morphology. Thesis (Master of Science)-University of Illinois, 1955. apud WALLIS, S.F ${ }^{162}$. Integration of certain variants of the facial skeleton in Class II, division 2 malocclusion. Angle Orthodont, v.33, n.1, p.60-7, Jan. 1963.

103. MARTIN, R.A. An analysis of normal cases and Class II, division 1 cases by cephalometric evaluation. Amer J Orthodont, v.44, n.2, p.147, Feb. 1958.

104. MARTINS, D.R. et al. Atlas de desenvolvimento craniofacial. Santos, 1998, São Paulo.

105. MARTINS, J.C.R. Avaliação cefalométrica comparativa dos resultados da interceptação da má oclusão de Classe II, divisão $1^{\text {a }}$ de Angle, efetuados com 0 aparelho extrabucal ou com 0 bionator. Araraquara, 1997. 333p. Tese (Livre-docência) - Faculdade de Odontologia de Araraquara, Universidade Estadual Paulista. 
106. McCALLIN, S.G. Extra-oral traction in orthodontics. Dent Practit Rec, v.12, n.1, p.25-38, Sept. 1961.

107. McNAMARA JÚNIOR, J.A. Components of Class II malocclusion in children 8-10 years of age. Angle Orthodont, v.51, n.3, p.177-202, July 1981.

108. McNAMARA JÚNIOR, J.A. A method of cephalometric evaluation. Amer J Orthodont, v.86, n.6, p.449-69, Dec. 1984.

109. MEACH, C.L. A cephalometric comparison of bony profile changes in Class II, Division 1 patients treated with extraoral force and functional jaw orthopedics. Amer J Orthodont, v.52, n.5, p.353-70, May 1966.

110. MIDTGARG, J.; BJÖRK, G.; LINDER-ARONSON, S. Reproducibility of cephalometric landmarks and errors of measurements of cephalometric cranial distances. Angle Orthodont, v.44, n.1, p.56-61, Jan. 1974.

111. MILLS, J.R.E. The effect of functional appliances on the skeletal pattern. Brit J Orthodont, v.18, n.4, p.267-75, Nov.1991.

112. MORRIS, D.O.; ILLING, H.M.; LEE, R.T. A prospective evaluation of bass, bionator and twin block appliances. Europ J Orthodont, v.20, n.6, p.663-84, Dec. 1998.

113. MOYERS, R.E. et al. Differential diagnosis of Class II malocclusions. Part 1: facial types associated with Class II malocclusions. Amer J Orthodont, v.78, n.5, p.477-94, Nov. 1980.

114. NELSON, B.G. What does extraoral anchorage accomplish? Amer J Orthodont, v.38, n.6, p.422-34, June 1952. 
115. NELSON, C.; HARKNESS, M.; HERBISON, P. Mandibular changes during functional appliance treatment. Amer J Orthodont Dentofac Orthop, v.104, n.2, p.153-61, Aug. 1993.

116. NELSON, W.E.; HIGLEY, L.B. The length of mandibular basal bone in normal occlusion and Class I malocclusion compared to Class II, division 1 malocclusion. Amer J Orthodont, v.34, n.7, p.610-7, July 1948.

117. NGAN, P.W.; BYCZEK, E.; SCHEICK, J. Longitudinal evaluation of growth changes in Class II division 1 subjects. Sem Orthod, v.3, n.4, p.22231, Dec. 1997.

118. O NEILL, K.; HARKNESS, M.; KNIGHT, R. Ratings of profile attractiveness after functional appliance treatment. Amer J Orthodont Dentofac Orthop, v.118, n.4, p.371-6, Out. 2000.

119. OP HEIJ, D.G. CALLAERT, H.; OPDEBEECK, H.M. The effect of the amount of protrusion built into the bionator on condylar growth and displacement: a clinical study. Amer J Orthodont Dentofac Orthop, v.95, n.5, p.401-409, May 1989.

120. OPPENHEIM, A. Biologic orthodontic therapy and reality. Angle Orthodont, v.6, n.3, p.153-83, July 1936.

121. PANCHERZ, H. A cephalometric analysis of skeletal and dental changes contributing to Class II correction in activator treatment. Amer J Orthodont Dentofac Orthop, v.85, n.2, p.125-34, Feb. 1984.

122. PFEIFFER, J.P. Should orthopaedic treatment of severe Class II malocclusions be related to growth? Europ J Orthodont, v.2, n.4, p.249-56, Nov. 1980. 
123. PFEIFFER, J.P.; GROBÉTY, D. The Class II malocclusion: differential diagnosis and clinical application of activators, extraoral traction, and fixed appliances. Amer J Orthodont, v.68, n.5, p.499-544, Nov. 1975.

124. PLINT, D.A. A method of treating class II, div.1 cases without using the lower arch for anchorage or traction. Transactions of the British Society for the study of orthodontics. p.49-55, 1961 apud FERGUSON, J.W. ${ }^{53}$ A new method of attaching headgear to upper removable appliances. Brit J Orthodont, v.10, n.1, p.48-9, Jan. 1983.

125. POSEN, A.L. The monobloc. Angle Orthodont, v.38, n.2, p.121-8, Apr. 1968.

126. PROFFIT, W.R. Contemporary Orthodontics. 2.ed., St. Louis, Mosby Year Book, 1993.

127. RABIE, A.B.M.; SHE, T.T.; HÄGG, U. Functional appliance therapy accelerates and enhances condylar growth. Amer J Orthodont Dentofac Orthop, v.123, n.1, p.40-8, Jan. 2003.

128. REMMER, K.R. et al. Cephalometric changes associated with treatment using the activator, the Fränkel appliance, and the fixed appliance. Amer J Orthodont Dentofac Orthop, v.88, n.5, p.363-72, Nov. 1985.

129. RENFROE, E.W. A study of the facial patterns associated with Class I, Class II, division 1, and Class II, division 2 malocclusions. Angle Orthodont, v.18, n.1-2, p.12-5, Jan./Apr. 1948.

130. RICKETTS, R.M. et al. An overview of computadorized cephalometrics. Amer J Orthodont, v.61, n.1, p.1-28, Jan. 1972. 
131. RIEDEL, R.A. The relation of maxillary structures to cranium in malocclusion and in normal occlusion. Angle Orthodont, v.22, n.3, p.142-5, July 1952.

132. ROBERTS, G.L. Functional appliances: Which one, when? Part 1-rationale for selection. Austr Orthodont J, v.9, p.160-78, Mar. 1985.

133. ROCK, W.P. The use of extra-oral traction with removable appliances. Brit Dent J, v.168, n.10, p.403-7, May 1990.

134. ROSENBLUM, R.E. Class II malocclusion: mandibular retrusion or maxillary protrusion? Angle Orthodont, v.65, n.1, p.49-62, 1995.

135. ROTHSTEIN, T.L. Facial morphology and growth from 10 to 14 years of age in children presenting Class II, division 1 malocclusion: a comparative roentgenographic cephalometric study. Amer $\mathbf{J}$ Orthodont, v.60, n.6, p.619-20, Dec. 1971.

136. ROTHSTEIN, T.L.; YOON-TARLIE, C. Dental and facial skeletal characteristics and growth of males and females with Class II, division 1 malocclusion between the ages of 10 and 14 (revisited) - Part 1: characteristics of size, form and position. Amer J Orthodont Dentofac Orthop, v.117, n.3, p.320-32, Mar. 2000.

137. SALZMANN, J.A. Criteria for extraction in orthodontic therapy related to dentofacial development. Amer J Orthodont, v.35, n.8, p.584-610, Aug. 1949.

138. SANDLER, P.J. Reproducibility of cephalometric measurements. Brit $\mathbf{J}$ Orthod, v.15, n.2, p.105-10, May 1988. 
139. SANTOS, M.A.C. Caracterização cefalométrica da Classe II, $1^{\frac{a}{}}$ divisão, esquelética. Bauru, 2003. Dissertação (Mestrado) - Faculdade de Odontologia de Bauru, Universidade de São Paulo.

140. SANTOS PINTO, A. et al. O aparelho extra-bucal de Thurow modificado no tratamento da Classe II com mordida aberta: caso clínico. Rev Dental Press Ortod Ortop Fac, v.6, n.1, p.57-62, jan./fev. 2001.

141. SARHAN, O.A.; HASHIM, H.A. Dento-skeletal components of Classll malocclusions for children with normal and retruded mandibles. J Clin Pediat Dent, v.18, n.2, p.99-103, Winter 1994.

142. SASSOUNI, V. The Class II syndrome: differencial diagnosis and treatment. Angle Orthodont, v.40, n.4, p.334-41, Oct. 1970.

143. SCHEIDEMAN, G.B. et al. Cephalometric analysis of dentofacial normals. Amer J Orthodont, v.78, n.4, p.404-20, Oct. 1980.

144. SCHULHOF, R.J.; ENGEL, G.A. Results of Class II functional appliance treatment. J Clin Orthodont, v.16, n.9, p.587-99, Sept. 1982.

145. SEÇKIN, O.; SURUCU, R. Treatment of class II, division 1 cases with a maxillary traction splint. Quintessence, v.21, n.3, p.209-15, 1990.

146. SERVOSS, J.M. Classification of occlusion. J Dent Child, v.42, n.1, p.2830, Jan./Feb. 1975.

147. THÜER, U.; INGERVALL, B.; BÜRGIN, W. Does the mandible alter its functional position during activator treatment? Amer J Orthodont Dentofac Orthop, v.96, n.6, p.477-84, Dec. 1989. 
148. THUROW, R.C. Craniomaxillary orthopedic correction with the en masse dental control. Amer J Orthodont, v.68, n.6, p.601-24, Dec. 1975.

149. TRPKOVA, B. et al. Cephalometric landmarks identification and reproducibility: a meta analysis. Amer J Orthodont Dentofac Orthop, v.112, n.2, p.165-70, Aug. 1997.

150. TSAMTSOURIS, A.; VEDRENNE, D. The use of the bionator appliance in the treatment of Class II, division 1 malocclusion in the late mixed dentition. J Pedod, v.8, n.78, p.78-100, 1983.

151. TULLEY, W.J. The scope and limitations of treatment with the activator. Amer J Orthodont, v.61, n.6, p.562-77, June 1972.

152. TULLOCH, J.F.; PROFFIT, W.R.; PHILLIPS, C. Influences on the outcome of early treatment for Class II malocclusion. Amer J Orthodont Dentofac Orthop, v.111, n.5, p.533-42, May 1997.

153. TULLOCH, J.F.; PHILLIPS, C.; PROFFIT, W.R. Benefit of early Class II treatment: progress report of a two-phase randomized clinical trial. Amer J Orthodont Dentofac Orthop, v.113, n.1, p.62-72, Jan. 1998.

154. TULLOCH, J.F. et al. The effect of early intervention on skeletal pattern in Class II malocclusion: a randomized clinical trial. Amer J Orthodont Dentofac Orthop, v.111, n.4, p.391-9, Apr. 1997.

155. TWEED, C. H. Clinical orthodontics. Saint Louis, Mosby Company, 1966.

156. ÜNER, O.; EROGLU, E.Y. Effects of a modified maxillary orthopaedic splint: a cephalometric evaluation. Europ J Orthodont, v.18, n.3, p.269-86, June 1996. 
157. URSI, W.J.S. Alteração clínica da face em crescimento: uma comparação cefalométrica entre os aparelhos extrabucal cervical, Fränkel (FR-2) e Herbst no tratamento das oclusões de Classe II, primeira divisão de Angle. Bauru. 1993. 168p. Tese (doutorado) Faculdade de Odontologia de Bauru, Universidade de São Paulo.

158. URSI, W.J.S.; McNAMARA JUNIOR, J. Crescimento craniofacial em pacientes apresentando maloclusão de Classe II e oclusão normal entre os 10 anos e os 12 anos de idade. Rev Dental Press Ortod Ortop Fac, v.2, n.5, p.49-59, set./out. 1997.

159. VALE, D.M.V. Avaliação cefalométrica das estruturas dentoesqueléticas em jovens portadores de Classe II, divisão 1, brasileiros, leucodermas e de origem mediterrânea. Bauru, 1985. 94p. Dissertação (Mestrado) - Faculdade de Odontologia de Bauru, Universidade de São Paulo.

160. VARGERVIK, K.; HARVOLD, E.P. Response to activator treatment in Class II malocclusions. Amer J Orthodont, v.88, n.3, p.242-51, Sept. 1985.

161. VIGORITO, J.W. Estudo comparativo de algumas características mandibulares em maloclusões de Classe I e Classe II, divisão 1, de Angle. Rev Fac Odont USP, v.11, n.1, p.75-82, jan./jun. 1973.

162. WALLIS, S.F. Integration of certain variants of the facial skeleton in Class II, division 2 malocclusion. Angle Orthodont, v.33, n.1, p.60-7, Jan. 1963.

163. WEBSTER, T.; HARKNESS, M., HERBISON, P. Associations between changes in selected facial dimensions and the outcome of orthodontic treatment. Amer J Orthodont Dentofac Orthop, v.110, n.1, p.46-53, July 1996. 
164. WHEELER, T.T. et al. Effectiveness of early treatment of Class II malocclusion. Amer J Orthodont Dentofac Orthop, v.121, n.1, p.917, Jan. 2002.

165. WIESLANDER, L.; LAGERSTRÖM, L. The effect of activator treatment on Class II malocclusions. Amer J Orthodont, v.75, n.1, p.20-6, Jan. 1979.

166. WOODSIDE, D.G. Cefalometric roentgenography. In: CLARK, J.W., Clinical dentistry. New York, Harper \& Row, 1980.

167. YOU, Z.H. et al. Dentoalveolar changes related to mandibular forward growth in untreated Class II persons. Amer J Orthodont Dentofac Orthop, v.120, n.6, p.598-607, Dec. 2001. 
ABSTRACT 


\section{ABSTRACT}

Comparative study of the maxillary splint and bionator appliances in the treatment of Class II, division1 malocclusion.

The purpose of this investigation was to evaluate and compare the cephalometric changes of maxillary splint and bionator appliances on individuals with Class II, division 1 malocclusion. Lateral cephalograms were available for 90 patients of both sex, divided in three groups of 30 each one. The first group served as a control group, with initial mean age of 10.02 years. The second group was treated with maxillary splint appliance with initial mean age of 10.02 years. The group 3 was treated with bionator appliance with initial mean age of 10.35 years. The lateral cephalometric headfilms were taken of each patient at the beginning and the end of treatment, in a total of 180 headfilms. The cephalometric variables were analyzed with statistical tests. The results showed that only maxillary splint influenced changes in forward growth of the maxilla and bionator appliances provides a statistically significant increase in mandibular protrusion. However, it was observed that both appliances provides an increase in total mandibular and body length, with greater values in group 2, but these results do not showed statistically differences. This study indicated that both appliances provide an improvement in the maxillomandibular relationship, compared to the control group. In addition, there were no statistically significant differences in the craniofacial growth pattern among the three groups nor in the facial heights. It was observed that both appliances produced lingual inclination and retrusion of the upper incisors. Maxillary splint provided lingual tipping of the lower incisors while bionator produced labial tipping and protrusion of these teeth. The lower molars showed a greater vertical development and extrusion in experimental groups. The maxillary splint produced distal movement of the first upper molars and bionator showed mesial inclination. This investigation indicated that both treated groups produced a retrusion in the upper lips with greater intensity in group 2. Maxillary splint produced a retrusion in the lower lip while bionator provided lower lip protrusion. 
APÊNDICES 


\section{Apêndice 1}

GRUPO 1 - Valores individuais das idades e período de avaliação

\begin{tabular}{|c|c|c|c|c|}
\hline Paciente & Gênero & Inicial & Final & Tempo \\
\hline 1. & $\mathrm{~F}$ & 11,50 & 12,50 & 1,00 \\
\hline 2. & $M$ & 9,50 & 11,17 & 1,67 \\
\hline 3. & $M$ & 9,92 & 10,92 & 1,00 \\
\hline 4. & $F$ & 9,83 & 10,75 & 0,92 \\
\hline 5. & $\mathrm{~F}$ & 10,58 & 12,00 & 1,42 \\
\hline 6. & $F$ & 9,58 & 11,67 & 2,08 \\
\hline 7. & $F$ & 10,17 & 11,00 & 0,83 \\
\hline 8. & $M$ & 9,25 & 10,17 & 0,92 \\
\hline 9. & $M$ & 9,92 & 12,00 & 2,08 \\
\hline 10. & $M$ & 10,33 & 11,50 & 1,17 \\
\hline 11. & $\mathrm{M}$ & 9,58 & 10,75 & 1,17 \\
\hline 12. & $M$ & 9,33 & 11,50 & 2,17 \\
\hline 13. & $\mathrm{~F}$ & 9,75 & 11,58 & 1,83 \\
\hline 14. & $F$ & 9,75 & 11,75 & 2,00 \\
\hline 15. & $\mathrm{~F}$ & 10,00 & 11,00 & 1,00 \\
\hline 16. & $\mathrm{~F}$ & 11,50 & 12,50 & 1,00 \\
\hline 17. & $M$ & 10,00 & 12,08 & 2,08 \\
\hline 18. & $\mathrm{~F}$ & 9,42 & 11,50 & 2,08 \\
\hline 19. & $M$ & 9,58 & 11,50 & 1,92 \\
\hline 20. & $F$ & 10,17 & 11,33 & 1,17 \\
\hline 21. & $M$ & 10,08 & 12,25 & 2,17 \\
\hline 22. & $M$ & 10,17 & 11,00 & 0,83 \\
\hline 23. & $\mathrm{M}$ & 11,00 & 12,08 & 1,08 \\
\hline 24. & $M$ & 9,75 & 11,83 & 2,08 \\
\hline 25. & $\mathrm{~F}$ & 10,25 & 12,25 & 2,00 \\
\hline 26. & $\mathrm{~F}$ & 10,42 & 11,33 & 0,92 \\
\hline 27. & $M$ & 9,58 & 11,50 & 1,92 \\
\hline 28. & $\mathrm{~F}$ & 10,17 & 10,92 & 0,75 \\
\hline 29. & $F$ & 9,58 & 11,58 & 2,00 \\
\hline 30. & $M$ & 11,00 & 12,08 & 1,08 \\
\hline
\end{tabular}




\section{Apêndice 2}

GRUPO 2- Valores individuais das idades e período de avaliação

\begin{tabular}{|c|c|c|c|c|}
\hline Paciente & Sexo & Inicial & Final & Tempo \\
\hline 1. & $\mathrm{~F}$ & 11,00 & 12,42 & 1,42 \\
\hline 2. & $\mathrm{~F}$ & 10,08 & 13,17 & 3,08 \\
\hline 3. & $\mathrm{~F}$ & 9,58 & 12,08 & 2,50 \\
\hline 4. & $\mathrm{M}$ & 11,17 & 12,33 & 1,17 \\
\hline 5. & $\mathrm{~F}$ & 9,75 & 10,92 & 1,17 \\
\hline 6. & $\mathrm{~F}$ & 8,83 & 10,25 & 1,42 \\
\hline 7. & $M$ & 10,00 & 11,17 & 1,17 \\
\hline 8. & $M$ & 10,00 & 11,75 & 1,75 \\
\hline 9. & $\mathrm{M}$ & 11,00 & 12,33 & 1,33 \\
\hline 10. & $M$ & 8,42 & 9,83 & 1,42 \\
\hline 11. & $\mathrm{~F}$ & 9,25 & 13,67 & 4,42 \\
\hline 12. & $\mathrm{M}$ & 8,17 & 10,08 & 1,92 \\
\hline 13. & $M$ & 8,42 & 10,00 & 1,58 \\
\hline 14. & $\mathrm{~F}$ & 8,58 & 10,33 & 1,75 \\
\hline 15. & $\mathrm{~F}$ & 9,33 & 10,75 & 1,42 \\
\hline 16. & $\mathrm{~F}$ & 10,17 & 12,00 & 1,83 \\
\hline 17. & $M$ & 9,67 & 12,33 & 2,67 \\
\hline 18. & $\mathrm{~F}$ & 10,33 & 12,00 & 1,67 \\
\hline 19. & $\mathrm{~F}$ & 11,00 & 12,42 & 1,42 \\
\hline 20. & $M$ & 9,42 & 11,08 & 1,67 \\
\hline 21. & $M$ & 11,08 & 12,00 & 0,92 \\
\hline 22. & $\mathrm{~F}$ & 10,00 & 12,83 & 2,83 \\
\hline 23. & $\mathrm{~F}$ & 10,75 & 11,92 & 1,17 \\
\hline 24. & $\mathrm{~F}$ & 11,00 & 12,83 & 1,83 \\
\hline 25. & $M$ & 11,08 & 12,00 & 0,92 \\
\hline 26. & $M$ & 12,25 & 14,33 & 2,08 \\
\hline 27. & $M$ & 9,92 & 12,83 & 2,92 \\
\hline 28. & $M$ & 9,67 & 11,92 & 2,25 \\
\hline 29. & $\mathrm{M}$ & 9,75 & 10,50 & 0,75 \\
\hline 30. & $\mathrm{~F}$ & 13,25 & 14,25 & 1,00 \\
\hline
\end{tabular}




\section{Apêndice 3}

GRUPO 3- Valores individuais das idades e período de avaliação

\begin{tabular}{|c|c|c|c|c|}
\hline Paciente & Sexo & Inicial & Final & Tempo \\
\hline 1. & $\mathrm{M}$ & 8,92 & 10,25 & 1,33 \\
\hline 2. & $\mathrm{~F}$ & 11,00 & 12,42 & 1,42 \\
\hline 3. & $\mathrm{~F}$ & 8,67 & 10,25 & 1,58 \\
\hline 4. & $F$ & 10,83 & 11,83 & 1,00 \\
\hline 5. & $M$ & 9,67 & 10,75 & 1,08 \\
\hline 6. & $M$ & 11,00 & 13,00 & 2,00 \\
\hline 7. & $M$ & 10,00 & 12,08 & 2,08 \\
\hline 8. & $M$ & 10,17 & 12,42 & 2,25 \\
\hline 9. & $M$ & 9,00 & 11,08 & 2,08 \\
\hline 10. & $F$ & 12,58 & 14,25 & 1,67 \\
\hline 11. & $M$ & 11,00 & 12,67 & 1,67 \\
\hline 12. & $\mathrm{~F}$ & 12,58 & 13,92 & 1,33 \\
\hline 13. & $\mathrm{~F}$ & 10,17 & 11,50 & 1,33 \\
\hline 14. & $\mathrm{~F}$ & 11,08 & 12,58 & 1,50 \\
\hline 15. & $M$ & 10,17 & 11,17 & 1,00 \\
\hline 16. & $M$ & 12,17 & 14,17 & 2,00 \\
\hline 17. & $M$ & 11,17 & 13,17 & 2,00 \\
\hline 18. & $M$ & 9,00 & 10,67 & 1,67 \\
\hline 19. & $\mathrm{~F}$ & 8,42 & 9,83 & 1,42 \\
\hline 20. & $F$ & 8,83 & 10,75 & 1,92 \\
\hline 21. & $F$ & 10,25 & 11,58 & 1,33 \\
\hline 22. & $M$ & 8,83 & 9,83 & 1,00 \\
\hline 23. & $\mathrm{~F}$ & 10,00 & 11,50 & 1,50 \\
\hline 24. & $\mathrm{~F}$ & 8,42 & 9,83 & 1,42 \\
\hline 25. & $\mathrm{~F}$ & 12,25 & 13,50 & 1,25 \\
\hline 26. & $M$ & 9,83 & 11,08 & 1,25 \\
\hline 27. & $\mathrm{~F}$ & 9,58 & 10,92 & 1,33 \\
\hline 28. & $\mathrm{~F}$ & 10,92 & 12,42 & 1,50 \\
\hline 29. & $\mathrm{M}$ & 10,33 & 12,50 & 2,17 \\
\hline 30. & $M$ & 10,83 & 12,17 & 1,33 \\
\hline
\end{tabular}


Apêndice 4

GRUPO 1- Valores do componente maxilar

\begin{tabular}{|c|c|c|c|c|c|c|}
\hline \multirow[t]{2}{*}{ N } & \multicolumn{2}{|c|}{ SNA (graus) } & \multicolumn{2}{|c|}{ Co-A (mm) } & \multicolumn{2}{|c|}{ Nperp-A (mm) } \\
\hline & Inicial & Final & Inicial & Final & Inicial & Final \\
\hline 1. & 84,00 & 80,40 & 82,50 & 82,70 & 0,80 & $-2,40$ \\
\hline 2. & 81,90 & 79,60 & 83,10 & 83,10 & $-1,10$ & $-3,50$ \\
\hline 3. & 77,70 & 77,10 & 76,70 & 80,20 & $-5,00$ & $-5,90$ \\
\hline 4. & 85,70 & 86,60 & 80,70 & 83,20 & 2,30 & 3,30 \\
\hline 5. & 76,00 & 75,60 & 84,60 & 84,90 & $-6,60$ & $-7,10$ \\
\hline 6. & 77,80 & 76,70 & 76,40 & 78,90 & $-4,80$ & $-6,00$ \\
\hline 7. & 81,90 & 82,30 & 81,10 & 82,70 & $-0,90$ & $-0,60$ \\
\hline 8. & 81,50 & 82,10 & 82,00 & 88,80 & $-1,40$ & $-0,90$ \\
\hline 9. & 80,30 & 79,60 & 86,40 & 89,20 & $-2,50$ & $-3,40$ \\
\hline 10. & 78,10 & 76,60 & 77,90 & 77,80 & $-4,20$ & $-5,70$ \\
\hline 11. & 83,10 & 81,80 & 83,40 & 88,70 & 0,10 & $-1,20$ \\
\hline 12. & 82,70 & 81,80 & 81,90 & 85,70 & $-0,20$ & $-1,20$ \\
\hline 13. & 83,10 & 84,70 & 79,80 & 81,30 & 0,10 & 1,70 \\
\hline 14. & 78,40 & 77,00 & 76,60 & 80,50 & $-4,20$ & $-5,80$ \\
\hline 15. & 83,10 & 83,90 & 79,30 & 78,30 & 0,10 & 0,80 \\
\hline 16. & 87,50 & 87,70 & 83,40 & 84,30 & 3,70 & 4,00 \\
\hline 17. & 76,80 & 74,20 & 85,10 & 85,10 & $-5,60$ & $-8,40$ \\
\hline 18. & 83,20 & 83,40 & 87,60 & 87,90 & 0,20 & 0,40 \\
\hline 19. & 78,40 & 75,40 & 74,70 & 88,90 & $-3,90$ & $-7,50$ \\
\hline 20. & 75,30 & 74,30 & 82,80 & 84,90 & $-7,40$ & $-8,90$ \\
\hline 21. & 79,30 & 79,20 & 84,00 & 85,60 & $-3,40$ & $-3,80$ \\
\hline 22. & 77,70 & 77,80 & 77,30 & 78,20 & $-4,70$ & $-4,70$ \\
\hline 23. & 82,30 & 80,90 & 88,20 & 88,60 & $-0,60$ & $-2,00$ \\
\hline 24. & 79,40 & 79,60 & 82,10 & 86,60 & $-3,00$ & $-3,10$ \\
\hline 25. & 80,00 & 78,60 & 78,20 & 77,90 & $-2,70$ & $-4,00$ \\
\hline 26. & 79,80 & 79,90 & 81,60 & 85,00 & $-2,90$ & $-2,90$ \\
\hline 27. & 80,10 & 81,70 & 83,30 & 86,10 & $-2,60$ & $-1,30$ \\
\hline 28. & 77,90 & 78,90 & 70,80 & 72,30 & $-4,00$ & $-3,40$ \\
\hline 29. & 79,90 & 79,60 & 78,10 & 79,80 & $-2,70$ & $-3,00$ \\
\hline 30. & 80,40 & 81,70 & 81,20 & 83,50 & 0,70 & $-2,90$ \\
\hline
\end{tabular}


Apêndice 5

GRUPO 1- Valores do componente mandibular

\begin{tabular}{|c|c|c|c|c|c|c|c|c|}
\hline \multirow[t]{2}{*}{$\mathrm{N}$} & \multicolumn{2}{|c|}{ SNB (graus) } & \multicolumn{2}{|c|}{ Nperp-P (mm) } & \multicolumn{2}{|c|}{ GO-GN (mm) } & \multicolumn{2}{|c|}{ CO-GN (mm) } \\
\hline & Inicial & Final & Inicial & Final & Inicial & Final & inicial & Final \\
\hline 1. & 75,60 & 74,10 & $-8,70$ & $-12,20$ & 61,40 & 65,80 & 94,80 & 95,70 \\
\hline 2. & 76,50 & 74,90 & $-9,00$ & $-11,70$ & 71,40 & 72,70 & 108,10 & 107,50 \\
\hline 3. & 74,80 & 74,40 & $-12,80$ & $-14,10$ & 69,10 & 71,50 & 102,10 & 108,40 \\
\hline 4. & 80,40 & 81,20 & $-3,60$ & $-1,30$ & 65,80 & 68,80 & 99,10 & 101,60 \\
\hline 5. & 70,80 & 71,40 & $-18,80$ & $-18,90$ & 66,10 & 68,60 & 101,20 & 101,80 \\
\hline 6. & 70,70 & 73,30 & $-19,10$ & $-15,50$ & 62,90 & 63,40 & 92,50 & 98,40 \\
\hline 7. & 79,70 & 80,00 & $-2,10$ & $-1,80$ & 66,90 & 68,90 & 98,30 & 100,90 \\
\hline 8. & 78,30 & 79,00 & $-6,90$ & $-6,10$ & 69,30 & 71,70 & 101,90 & 107,50 \\
\hline 9. & 73,90 & 73,30 & $-12,80$ & $-13,90$ & 66,10 & 68,40 & 101,70 & 105,40 \\
\hline 10. & 74,30 & 74,50 & $-10,30$ & $-10,40$ & 63,50 & 65,00 & 96,50 & 99,50 \\
\hline 11. & 76,90 & 75,90 & $-9,70$ & $-11,10$ & 67,30 & 71,80 & 100,00 & 107,00 \\
\hline 12. & 75,10 & 75,20 & $-11,70$ & $-13,10$ & 68,40 & 71,80 & 101,70 & 107,00 \\
\hline 13. & 77,70 & 78,60 & $-9,30$ & $-8,20$ & 64,60 & 68,50 & 98,00 & 99,10 \\
\hline 14. & 73,50 & 71,50 & $-14,70$ & $-18,50$ & 67,60 & 69,20 & 96,00 & 101,00 \\
\hline 15. & 81,40 & 82,70 & $-2,40$ & $-0,20$ & 62,20 & 64,80 & 98,00 & 97,20 \\
\hline 16. & 79,50 & 80,80 & $-5,90$ & $-3,80$ & 66,20 & 68,00 & 100,00 & 103,00 \\
\hline 17. & 69,50 & 67,50 & $-16,60$ & $-19,60$ & 65,10 & 66,90 & 99,30 & 101,10 \\
\hline 18. & 78,90 & 78,80 & $-5,50$ & $-5,00$ & 71,10 & 73,30 & 104,90 & 104,30 \\
\hline 19. & 76,10 & 73,20 & $-10,80$ & $-17,50$ & 64,30 & 73,90 & 98,20 & 115,30 \\
\hline 20. & 69,60 & 68,30 & $-19,60$ & $-23,70$ & 62,00 & 63,30 & 102,00 & 102,70 \\
\hline 21. & 73,20 & 73,60 & $-16,00$ & $-15,10$ & 65,30 & 68,30 & 103,50 & 104,80 \\
\hline 22. & 76,00 & 75,60 & $-10,50$ & $-11,00$ & 65,90 & 67,20 & 98,10 & 98,10 \\
\hline 23. & 76,80 & 76,00 & $-10,20$ & $-11,40$ & 67,10 & 70,00 & 104,50 & 107,00 \\
\hline 24. & 72,30 & 72,00 & $-15,80$ & $-17,90$ & 62,50 & 64,90 & 95,00 & 99,70 \\
\hline 25. & 74,60 & 74,50 & $-11,70$ & $-11,40$ & 61,10 & 60,90 & 94,00 & 94,60 \\
\hline 26. & 75,10 & 74,70 & $-12,90$ & $-12,60$ & 64,40 & 68,30 & 97,90 & 103,20 \\
\hline 27. & 75,50 & 76,80 & $-9,00$ & $-7,40$ & 73,80 & 73,80 & 107,00 & 111,20 \\
\hline 28. & 72,00 & 74,50 & $-14,90$ & $-12,30$ & 56,90 & 58,20 & 87,20 & 88,70 \\
\hline 29. & 76,80 & 76,90 & $-8,80$ & $-8,20$ & 62,90 & 65,30 & 96,60 & 100,50 \\
\hline 30. & 75,30 & 72,30 & $-0,50$ & $-11,50$ & 65,80 & 70,90 & 99,50 & 102,30 \\
\hline
\end{tabular}


Apêndice 6

GRUPO 1 - Valores da relação sagital maxilomandibular

\begin{tabular}{|c|c|c|c|c|}
\hline \multirow[t]{2}{*}{$\mathrm{N}$} & \multicolumn{2}{|c|}{ ANB (graus) } & \multicolumn{2}{|c|}{ NAP (graus) } \\
\hline & Inicial & Final & Inicial & Final \\
\hline 1. & 8,30 & 6,40 & 14,70 & 12,60 \\
\hline 2. & 5,40 & 4,70 & 7,40 & 5,50 \\
\hline 3. & 3,00 & 2,70 & 3,50 & 2,50 \\
\hline 4. & 5,40 & 5,40 & 10,00 & 9,30 \\
\hline 5. & 5,20 & 4,20 & 9,70 & 8,60 \\
\hline 6. & 7,00 & 3,50 & 13,40 & 6,60 \\
\hline 7. & 2,10 & 2,30 & 0,70 & 1,00 \\
\hline 8. & 3,20 & 3,00 & 5,70 & 5,80 \\
\hline 9. & 6,30 & 6,30 & 10,90 & 11,20 \\
\hline 10. & 3,90 & 2,10 & 3,40 & $-0,50$ \\
\hline 11. & 6,20 & 6,00 & 11,70 & 10,60 \\
\hline 12. & 7,70 & 6,50 & 12,30 & 11,90 \\
\hline 13. & 5,40 & 6,20 & 12,30 & 15,40 \\
\hline 14. & 4,90 & 5,60 & 8,60 & 9,80 \\
\hline 15. & 1,70 & 1,10 & 3,60 & 2,30 \\
\hline 16. & 8,00 & 6,90 & 15,60 & 13,50 \\
\hline 17. & 7,30 & 6,60 & 8,30 & 5,50 \\
\hline 18. & 4,30 & 4,60 & 7,90 & 7,60 \\
\hline 19. & 2,30 & 2,20 & 3,70 & 3,30 \\
\hline 20. & 5,60 & 6,10 & 8,40 & 10,00 \\
\hline 21. & 6,00 & 5,50 & 11,40 & 10,80 \\
\hline 22. & 1,60 & 2,20 & 1,80 & 2,30 \\
\hline 23. & 5,50 & 4,90 & 11,60 & 10,00 \\
\hline 24. & 7,10 & 7,60 & 13,00 & 15,00 \\
\hline 25. & 5,30 & 4,00 & 9,90 & 6,60 \\
\hline 26. & 4,70 & 5,20 & 11,20 & 9,50 \\
\hline 27. & 4,60 & 4,80 & 4,50 & 5,40 \\
\hline 28. & 5,90 & 4,40 & 10,50 & 9,50 \\
\hline 29. & 3,10 & 2,70 & 4,60 & 2,90 \\
\hline 30. & 5,10 & 4,80 & 8,60 & 8,60 \\
\hline
\end{tabular}


Apêndice 7

GRUPO 1 - Valores da relação vertical

\begin{tabular}{|c|c|c|c|c|c|c|c|c|}
\hline \multirow[t]{2}{*}{$N$} & \multicolumn{2}{|c|}{ SN.GoGn (graus) } & \multicolumn{2}{|c|}{ SN.PP (graus) } & \multicolumn{2}{|c|}{$\operatorname{AFAl}(\mathrm{mm})$} & \multicolumn{2}{|c|}{ S-GO (mm) } \\
\hline & Inicial & Final & Inicial & Final & Inicial & Final & Inicial & Final \\
\hline 1. & 31,50 & 34,30 & 10,40 & 13,60 & 52,70 & 53,20 & 57,50 & 57,20 \\
\hline 2. & 37,20 & 37,90 & 5,50 & 7,70 & 67,10 & 67,20 & 70,40 & 70,50 \\
\hline 3. & 37,50 & 38,70 & 4,20 & 5,10 & 65,90 & 69,70 & 66,20 & 70,50 \\
\hline 4. & 26,80 & 22,80 & 4,70 & 6,40 & 59,40 & 59,90 & 69,50 & 76,70 \\
\hline 5. & 37,40 & 36,90 & 9,80 & 9,30 & 59,40 & 59,40 & 58,20 & 59,90 \\
\hline 6. & 37,10 & 34,20 & 8,20 & 9,80 & 58,30 & 56,50 & 58,80 & 63,80 \\
\hline 7. & 24,30 & 23,10 & 8,60 & 8,90 & 51,00 & 50,60 & 62,60 & 64,90 \\
\hline 8. & 31,70 & 29,20 & 3,50 & 6,20 & 61,00 & 60,50 & 65,90 & 69,50 \\
\hline 9. & 31,50 & 31,60 & 11,90 & 11,90 & 56,20 & 57,80 & 63,10 & 66,30 \\
\hline 10. & 31,40 & 32,20 & 4,30 & 5,90 & 56,20 & 57,40 & 62,00 & 65,70 \\
\hline 11. & 30,70 & 32,30 & 8,90 & 9,20 & 62,40 & 64,40 & 68,50 & 70,00 \\
\hline 12. & 36,40 & 38,30 & 8,80 & 7,50 & 64,60 & 66,60 & 65,60 & 66,10 \\
\hline 13. & 31,30 & 30,30 & 11,40 & 11,80 & 55,40 & 57,40 & 66,60 & 68,00 \\
\hline 14. & 33,80 & 34,30 & 6,60 & 10,50 & 62,20 & 63,10 & 63,10 & 66,50 \\
\hline 15. & 25,70 & 24,90 & 7,10 & 7,20 & 52,80 & 53,10 & 68,70 & 68,60 \\
\hline 16. & 30,70 & 29,30 & 6,50 & 6,50 & 62,50 & 63,20 & 66,30 & 70,70 \\
\hline 17. & 28,70 & 30,30 & 6,20 & 8,80 & 57,50 & 59,80 & 66,50 & 67,50 \\
\hline 18. & 27,60 & 27,80 & 6,30 & 6,60 & 58,00 & 58,70 & 68,30 & 69,60 \\
\hline 19. & 38,50 & 38,00 & 7,70 & 10,20 & 58,00 & 64,00 & 59,40 & 66,80 \\
\hline 20. & 38,40 & 39,10 & 14,00 & 14,30 & 58,30 & 61,60 & 62,20 & 64,40 \\
\hline 21. & 35,50 & 35,20 & 12,30 & 12,40 & 58,40 & 59,20 & 64,60 & 64,90 \\
\hline 22. & 31,00 & 30,90 & 7,70 & 7,20 & 59,60 & 58,70 & 66,00 & 66,80 \\
\hline 23. & 32,30 & 32,40 & 9,80 & 8,20 & 60,00 & 63,30 & 63,70 & 67,20 \\
\hline 24. & 30,70 & 31,30 & 6,20 & 7,30 & 58,30 & 62,70 & 62,70 & 65,80 \\
\hline 25. & 32,20 & 30,90 & 7,20 & 8,80 & 54,70 & 53,80 & 61,00 & 62,00 \\
\hline 26. & 33,40 & 30,30 & 10,10 & 8,60 & 56,70 & 60,80 & 62,30 & 68,00 \\
\hline 27. & 31,30 & 29,80 & 4,70 & 5,50 & 64,60 & 66,20 & 67,80 & 75,00 \\
\hline 28. & 33,90 & 31,80 & 6,60 & 6,00 & 53,80 & 55,80 & 56,00 & 60,20 \\
\hline 29. & 29,90 & 30,10 & 3,30 & 4,70 & 59,10 & 60,10 & 67,10 & 68,80 \\
\hline 30. & 32,60 & 32,00 & 7,60 & 7,20 & 58,80 & 61,70 & 65,10 & 66,70 \\
\hline
\end{tabular}


Apêndice 8

GRUPO 1- Valores do componente dentoalveolar superior

\begin{tabular}{|c|c|c|c|c|c|c|c|c|}
\hline \multirow[t]{2}{*}{$\mathrm{N}$} & \multicolumn{2}{|c|}{ 1. NA (graus) } & \multicolumn{2}{|c|}{ 1-NA (mm) } & \multicolumn{2}{|c|}{$\underline{6}-\mathrm{PP}(\mathrm{mm})$} & \multicolumn{2}{|c|}{$\underline{6}-\mathrm{FHp}(\mathrm{mm})$} \\
\hline & Inicial & Final & Inicial & Final & Inicial & Final & Inicial & Final \\
\hline 1. & 41,00 & 36,20 & 6,00 & 7,40 & 16,00 & 16,70 & 40,20 & 37,90 \\
\hline 2. & 32,60 & 34,30 & 5,30 & 7,00 & 20,90 & 21,70 & 32,90 & 35,20 \\
\hline 3. & 26,40 & 32,00 & 5,60 & 6,50 & 20,20 & 22,00 & 31,10 & 33,60 \\
\hline 4. & 16,30 & 21,20 & 3,70 & 4,60 & 17,40 & 19,80 & 39,70 & 41,90 \\
\hline 5. & 10,20 & 11,00 & 1,90 & 2,00 & 16,30 & 17,20 & 28,00 & 30,00 \\
\hline 6. & 18,30 & 24,30 & 2,90 & 4,20 & 17,60 & 18,20 & 32,00 & 29,60 \\
\hline 7. & 29,70 & 31,90 & 6,30 & 5,60 & 18,50 & 19,00 & 36,40 & 35,90 \\
\hline 8. & 22,50 & 27,00 & 4,20 & 5,30 & 16,50 & 19,00 & 32,10 & 34,70 \\
\hline 9. & 11,30 & 11,00 & 2,20 & 2,50 & 17,60 & 17,60 & 37,30 & 38,10 \\
\hline 10. & 28,00 & 30,00 & 5,40 & 6,40 & 18,00 & 19,80 & 35,80 & 34,80 \\
\hline 11. & 19,90 & 24,10 & 2,60 & 4,50 & 20,30 & 21,00 & 35,70 & 37,00 \\
\hline 12. & 22,00 & 20,30 & 3,80 & 3,70 & 21,30 & 20,80 & 33,30 & 33,70 \\
\hline 13. & 26,80 & 22,90 & 5,30 & 3,30 & 17,70 & 19,50 & 33,70 & 35,40 \\
\hline 14. & 23,90 & 21,30 & 5,20 & 4,50 & 19,50 & 20,80 & 28,40 & 28,80 \\
\hline 15. & 34,60 & 36,30 & 7,20 & 8,40 & 17,80 & 17,20 & 36,70 & 42,10 \\
\hline 16. & 22,60 & 27,00 & 5,70 & 7,90 & 21,10 & 23,00 & 36,50 & 38,20 \\
\hline 17. & 31,70 & 22,80 & 6,10 & 4,60 & 16,40 & 17,20 & 28,50 & 23,10 \\
\hline 18. & 17,80 & 19,60 & 4,90 & 4,40 & 17,70 & 19,20 & 37,90 & 39,10 \\
\hline 19. & 22,10 & 26,70 & 4,50 & 6,80 & 18,40 & 21,10 & 29,10 & 32,70 \\
\hline 20. & 30,80 & 28,20 & 5,40 & 5,80 & 15,60 & 20,90 & 23,60 & 23,60 \\
\hline 21. & 27,90 & 25,30 & 5,60 & 4,70 & 18,30 & 18,50 & 28,40 & 28,60 \\
\hline 22. & 27,10 & 25,90 & 6,30 & 6,30 & 19,30 & 19,20 & 32,00 & 32,60 \\
\hline 23. & 23,40 & 19,30 & 3,10 & 3,90 & 17,80 & 18,60 & 33,60 & 33,80 \\
\hline 24. & 25,90 & 29,50 & 4,40 & 3,60 & 17,80 & 18,80 & 32,50 & 33,30 \\
\hline 25. & 33,00 & 37,40 & 3,50 & 6,60 & 16,50 & 17,20 & 34,20 & 34,30 \\
\hline 26. & 23,20 & 25,50 & 3,80 & 4,60 & 18,80 & 19,40 & 31,70 & 32,40 \\
\hline 27. & 30,60 & 25,70 & 7,30 & 5,40 & 22,30 & 23,70 & 33,50 & 33,00 \\
\hline 28. & 17,40 & 17,90 & 3,60 & 4,10 & 16,70 & 18,10 & 26,70 & 28,90 \\
\hline 29. & 24,70 & 29,30 & 5,20 & 6,10 & 17,20 & 18,80 & 31,60 & 33,20 \\
\hline 30. & 25,10 & 23,40 & 4,80 & 5,60 & 18,50 & 19,70 & 32,70 & 37,90 \\
\hline
\end{tabular}


Apêndice 9

GRUPO 1 - Valores do componente dentoalveolar inferior

\begin{tabular}{|c|c|c|c|c|c|c|c|c|c|c|}
\hline \multirow[t]{2}{*}{$\mathrm{N}$} & \multicolumn{2}{|c|}{ IMPA (graus) } & \multicolumn{2}{|c|}{ 1.NB (graus) } & \multicolumn{2}{|c|}{$\overline{1}-\mathrm{NB}(\mathrm{mm})$} & \multicolumn{2}{|c|}{$\overline{6}$-GoMe $(\mathrm{mm})$} & \multicolumn{2}{|c|}{$\overline{6}-\mathrm{FHP}(\mathrm{mm})$} \\
\hline & icial & Final & Inicial & Final & Inicial & Final & Inicial & Final & Inicial & Fin \\
\hline 1. & \begin{tabular}{|l|}
96,80 \\
\end{tabular} & 94,20 & 26,80 & 26,20 & 4,20 & 4,00 & 24,40 & 24,60 & 38,60 & 36,30 \\
\hline 2. & \begin{tabular}{|l|}
88,80 \\
\end{tabular} & 86,00 & 24,80 & 21,40 & 6,10 & 6,10 & 27,40 & 27,50 & 35,20 & 35,30 \\
\hline 3. & 84,40 & 85,40 & 19,30 & 20,30 & 4,00 & 4,50 & 26,00 & 27,30 & 32,10 & 60 \\
\hline 4. & 106,10 & 102,60 & 35,90 & 29,70 & 5,30 & 5,50 & 29,80 & 30,50 & 40,00 & 41,40 \\
\hline 5. & 3,70 & 94,50 & 24,60 & 25,20 & 3,50 & 3,30 & 26,30 & 27,20 & 28,30 & 30,90 \\
\hline 6. & \begin{tabular}{|l|}
95,70 \\
\end{tabular} & 98,30 & 25,80 & 28,20 & 5,70 & 4,30 & 24,80 & 24,70 & 29,40 & 80 \\
\hline 7. & 100,70 & 103,30 & 27,60 & 28,70 & 4,10 & 3,80 & 23,40 & 24,10 & 36,60 & 36,50 \\
\hline 8. & \begin{tabular}{|l|}
96,00 \\
\end{tabular} & 93,60 & 29,50 & 24,30 & 5,00 & 4,20 & 24,90 & 26,50 & 33,30 & 3 \\
\hline 9. & 00 & 92,30 & 21,30 & 19,70 & 3,30 & 4,20 & 26,10 & 27,70 & 34,80 & \\
\hline 10. & 96,00 & 94,00 & 23,20 & 22,30 & 3,20 & 4,10 & 23,00 & 23,20 & 33,00 & 33,30 \\
\hline 11. & & & & & & & & & & \\
\hline 12. & \begin{tabular}{|l|}
81,80 \\
\end{tabular} & 83,40 & 15,20 & 18,60 & 3,80 & 3,10 & 26,70 & 26,40 & 34,40 & 34,90 \\
\hline 13. & \begin{tabular}{|l|}
96,10 \\
\end{tabular} & 98,00 & 27,00 & 30,10 & 6,00 & 7,10 & 27,00 & 27,10 & 34,10 & 36,40 \\
\hline 14. & \begin{tabular}{|l|}
94,20 \\
\end{tabular} & 96,40 & 24,30 & 24,50 & 4,40 & 5,30 & 27,20 & 29,60 & 26,90 & 90 \\
\hline 15. & \begin{tabular}{|l|}
95,20 \\
\end{tabular} & \begin{tabular}{|l|}
94,20 \\
\end{tabular} & 25,10 & 23,60 & 3,30 & 3,30 & 24,90 & 27,10 & 36,30 & 40,20 \\
\hline 16. & & 10 & 32,20 & & & 0 & & & 37,50 & \\
\hline 17. & 87,80 & 98,50 & 7,60 & 19,20 & 1,30 & 4,00 & 26,40 & 26,70 & 27,30 & 22,50 \\
\hline 18. & \begin{tabular}{|l|}
104,60 \\
\end{tabular} & 105,60 & 33,00 & 34,60 & 5,90 & 4,90 & 27,20 & 25,90 & 38,40 & 39,80 \\
\hline 19. & \begin{tabular}{|l|}
85,70 \\
\end{tabular} & 84,80 & 22,10 & 17,70 & 3,90 & 5,10 & 24,60 & 28,80 & 32,60 & 33,80 \\
\hline 20. & & 97,80 & 24,50 & 27,40 & 5,00 & 4,70 & 26,90 & 25,60 & 23,80 & 24,90 \\
\hline 21. & & 96,50 & 25,50 & 27 & 5,10 & 5,60 & 27,20 & & 29,90 & \\
\hline 22. & \begin{tabular}{|l|}
94,80 \\
\end{tabular} & 94,00 & 23,80 & 22,20 & 2,30 & 2,50 & 26,40 & 25,80 & 33,60 & 33,20 \\
\hline 23. & \begin{tabular}{|l|}
96,00 \\
\end{tabular} & 95,00 & 28,60 & 27,20 & 4,30 & 5,70 & 27,50 & 28,80 & 34,90 & 35,20 \\
\hline 24. & \begin{tabular}{|l|}
105,90 \\
\end{tabular} & 106,10 & 30,80 & 31,70 & 6,40 & 6,40 & 27,30 & 28,60 & 31,10 & 33,80 \\
\hline 25. & 93,00 & 92,20 & 22,00 & 20,30 & 3,40 & 4,00 & 24,10 & 24,30 & 34,20 & 35,20 \\
\hline 26. & \begin{tabular}{|l|}
96,50 \\
\end{tabular} & 96,30 & 27,80 & 24,20 & 3,90 & 3,70 & 25,60 & 28,70 & 33,30 & 34,40 \\
\hline 27. & \begin{tabular}{|l|}
88,00 \\
\end{tabular} & 93,10 & 16,70 & 22,00 & 3,90 & 4,40 & 26,20 & 27,30 & 31,70 & 33,20 \\
\hline 28. & \begin{tabular}{|l|}
98,20 \\
\end{tabular} & 103,60 & 27,20 & 32,80 & 3,70 & 3,60 & 21,80 & 23,50 & 24,50 & 27,80 \\
\hline 29. & 88,60 & \begin{tabular}{|l|}
90,20 \\
\end{tabular} & 17,80 & 19,10 & 3,60 & 4,10 & 25,60 & 26,60 & 31,80 & 35,40 \\
\hline 30. & 94,80 & 99,80 & 24,70 & 21,30 & 4,60 & 4,70 & 26,30 & 26,80 & 32,70 & 34,50 \\
\hline
\end{tabular}




\section{Apêndice 10}

GRUPO 1- Valores do perfil tegumentar

\begin{tabular}{|c|c|c|c|c|c|c|}
\hline \multirow[t]{2}{*}{$N$} & \multicolumn{2}{|c|}{ ANL (graus) } & \multicolumn{2}{|c|}{ Ls-Pog'Sn (mm) } & \multicolumn{2}{|c|}{ Li-Pog'Sn (mm) } \\
\hline & Inicial & Final & Inicial & Final & Inicial & Fina \\
\hline 1. & 105,50 & 105,80 & 6,10 & 5,70 & 3,30 & 1,80 \\
\hline 2. & 103,60 & 103,50 & 3,80 & 3,80 & 3,20 & 2,00 \\
\hline 3. & 118,80 & 117,90 & 2,70 & 3,30 & 3,40 & 3,80 \\
\hline 4. & 114,20 & 113,60 & 4,50 & 5,50 & 3,50 & 4,60 \\
\hline 5. & 119,50 & 115,80 & 4,20 & 3,30 & 2,90 & 2,80 \\
\hline 6. & 119,10 & 118,10 & 3,50 & 2,90 & 2,50 & 4,80 \\
\hline 7. & 110,20 & 117,40 & 3,10 & 2,30 & 0,60 & 0,20 \\
\hline 8. & 119,90 & 119,70 & 3,50 & 3,10 & 1,80 & 2,70 \\
\hline 9. & 128,20 & 129,30 & 1,50 & 1,70 & 2,10 & 2,60 \\
\hline 10. & 113,50 & 111,60 & 5,70 & 6,00 & 3,60 & 4,20 \\
\hline 11. & 125,60 & 114,20 & 4,10 & 6,10 & 4,50 & 6,90 \\
\hline 12. & 120,50 & 104,50 & 4,30 & 5,10 & 0,70 & 3,70 \\
\hline 13. & 113,60 & 124,50 & 6,60 & 4,50 & 4,10 & 2,60 \\
\hline 14. & 131,60 & 133,20 & 3,00 & 3,10 & 3,10 & 4,60 \\
\hline 15. & 112,30 & 111,80 & 5,00 & 5,50 & 5,40 & 5,00 \\
\hline 16. & 104,60 & 104,10 & 6,40 & 6,30 & 3,70 & 3,40 \\
\hline 17. & 121,10 & 133,30 & 4,50 & 2,20 & $-7,50$ & $-2,50$ \\
\hline 18. & 125,60 & 128,30 & 3,10 & 3,10 & 1,50 & 2,40 \\
\hline 19. & 124,00 & 128,10 & 1,20 & 2,10 & 2,30 & 1,70 \\
\hline 20. & 105,80 & 106,40 & 3,60 & 4,50 & 0,80 & 1,20 \\
\hline 21. & 132,90 & 116,30 & 1,70 & 3,00 & 1,40 & 0,60 \\
\hline 22. & 123,40 & 112,00 & 2,50 & 3,10 & 2,90 & 1,40 \\
\hline 23. & 111,40 & 114,10 & 7,80 & 6,70 & 4,90 & 5,00 \\
\hline 24. & 123,00 & 134,90 & 5,10 & 3,30 & 5,50 & 2,40 \\
\hline 25. & 122,60 & 125,90 & 2,20 & 3,10 & $-0,10$ & 0,90 \\
\hline 26. & 113,70 & 130,90 & 3,30 & 2,60 & 2,60 & 3,20 \\
\hline 27. & 134,80 & 131,90 & 0,90 & 2,20 & $-0,70$ & 1,20 \\
\hline 28. & 124,00 & 118,00 & 1,90 & 2,00 & 0,20 & 0,40 \\
\hline 29. & 110,10 & 102,00 & 3,00 & 3,80 & 3,40 & 3,30 \\
\hline 30. & 106,30 & 118,20 & 3,50 & 3,80 & 2,30 & 2,60 \\
\hline
\end{tabular}


Apêndice 11

GRUPO 2- Valores do componente maxilar

\begin{tabular}{c|c|c|c|c|c|c}
\hline \multirow{2}{*}{$\mathrm{N}$} & \multicolumn{2}{|c|}{ SNA (graus) } & \multicolumn{2}{c|}{ Co-A (mm) } & \multicolumn{2}{c}{ Nperp-A (mm) } \\
\hline & Inicial & Final & Inicial & Final & Inicial & Final \\
\hline 1. & 79,30 & 76,90 & 78,40 & 79,20 & $-3,00$ & $-5,20$ \\
\hline 2. & 85,40 & 83,60 & 75,50 & 78,80 & 1,80 & 0,50 \\
\hline 3. & 80,00 & 79,50 & 79,20 & 78,00 & $-2,60$ & $-2,90$ \\
\hline 4. & 82,50 & 80,20 & 77,40 & 81,40 & $-0,40$ & $-2,50$ \\
\hline 5. & 71,00 & 71,00 & 74,60 & 75,10 & $-10,60$ & $-11,10$ \\
\hline 6. & 81,60 & 78,20 & 79,10 & 79,00 & $-1,20$ & $-4,20$ \\
\hline 7. & 82,10 & 79,50 & 78,20 & 82,60 & $-0,70$ & $-3,30$ \\
\hline 8. & 76,00 & 76,20 & 78,00 & 80,40 & $-6,40$ & $-6,40$ \\
\hline 9. & 81,40 & 79,70 & 75,20 & 77,40 & $-1,40$ & $-3,10$ \\
\hline 10. & 85,30 & 83,10 & 81,60 & 89,20 & 2,00 & 0,10 \\
\hline 11. & 80,30 & 77,10 & 75,40 & 75,80 & $-2,30$ & $-5,30$ \\
\hline 12. & 78,00 & 77,30 & 77,90 & 81,90 & $-4,30$ & $-5,30$ \\
\hline 13. & 80,10 & 78,40 & 82,70 & 85,80 & $-3,00$ & $-4,90$ \\
\hline 14. & 82,20 & 82,50 & 82,30 & 82,40 & $-0,70$ & $-0,40$ \\
\hline 15. & 82,20 & 81,00 & 78,40 & 82,40 & $-0,70$ & $-1,90$ \\
\hline 16. & 79,20 & 78,50 & 75,70 & 78,00 & $-3,40$ & $-4,10$ \\
\hline 17. & 84,10 & 83,50 & 85,00 & 83,70 & 0,90 & 0,40 \\
\hline 18. & 86,90 & 83,70 & 76,20 & 81,00 & 3,10 & 0,60 \\
\hline 19. & 84,30 & 83,30 & 81,30 & 82,70 & 1,10 & 0,30 \\
\hline 20. & 76,10 & 74,80 & 78,60 & 79,10 & $-6,10$ & $-7,40$ \\
\hline 21. & 80,00 & 78,20 & 80,50 & 82,50 & $-2,80$ & $-4,80$ \\
\hline 22. & 79,30 & 78,50 & 77,60 & 79,60 & $-3,20$ & $-3,90$ \\
\hline 23. & 84,90 & 82,60 & 75,70 & 77,70 & 1,60 & $-0,30$ \\
\hline 24. & 86,60 & 83,70 & 79,30 & 79,10 & 3,00 & 0,60 \\
\hline 25. & 84,00 & 83,30 & 85,50 & 84,80 & 0,90 & 0,30 \\
\hline 26. & 84,30 & 83,60 & 80,70 & 82,00 & 1,20 & 0,50 \\
\hline 27. & 82,10 & 79,60 & 81,40 & 82,70 & $-0,80$ & $-3,20$ \\
\hline 28. & 83,50 & 83,20 & 74,20 & 73,90 & 0,40 & 0,20 \\
\hline 29. & 81,60 & 79,90 & 82,20 & 84,70 & $-1,20$ & $-2,80$ \\
\hline 30. & 76,90 & 76,10 & 77,10 & 75,70 & $-5,40$ & $-6,10$ \\
\hline & & & & & & \\
\hline
\end{tabular}




\section{Apêndice 12}

GRUPO 2- Valores do componente mandibular

\begin{tabular}{|c|c|c|c|c|c|c|c|c|}
\hline \multirow[t]{2}{*}{$N$} & \multicolumn{2}{|c|}{ SNB (graus) } & \multicolumn{2}{|c|}{ Nperp-P (mm) } & \multicolumn{2}{|c|}{ GO-GN (mm) } & \multicolumn{2}{|c|}{ CO-GN (mm) } \\
\hline & Inicial & Final & Inicial & Final & Inicial & Final & inicial & Final \\
\hline 1. & 71,10 & 71,90 & $-17,70$ & $-17,90$ & 60,30 & 65,60 & 92,60 & 97,70 \\
\hline 2. & 79,10 & 79,40 & $-3,90$ & $-4,80$ & 64,50 & 68,40 & 92,30 & 100,30 \\
\hline 3. & 74,50 & 74,40 & $-9,30$ & $-10,10$ & 68,00 & 68,40 & 100,10 & 100,80 \\
\hline 4. & 75,90 & 77,80 & $-6,20$ & $-2,90$ & 68,10 & 72,00 & 96,90 & 106,60 \\
\hline 5. & 67,20 & 67,30 & $-23,80$ & $-24,90$ & 59,00 & 61,90 & 94,80 & 98,30 \\
\hline 6. & 71,40 & 71,70 & $-16,60$ & $-16,70$ & 62,30 & 65,80 & 92,50 & 96,00 \\
\hline 7. & 71,60 & 72,80 & $-17,80$ & $-17,20$ & 58,80 & 66,70 & 92,20 & 105,80 \\
\hline 8. & 72,00 & 73,20 & $-17,70$ & $-15,80$ & 64,20 & 67,00 & 95,80 & 99,20 \\
\hline 9. & 75,60 & 74,90 & $-10,80$ & $-11,70$ & 64,10 & 67,10 & 98,80 & 102,30 \\
\hline 10. & 79,00 & 80,80 & $-3,40$ & $-0,20$ & 67,20 & 74,60 & 101,00 & 114,40 \\
\hline 11. & 73,00 & 72,80 & $-14,10$ & $-15,40$ & 62,30 & 63,90 & 93,20 & 98,10 \\
\hline 12. & 73,90 & 73,60 & $-15,80$ & $-16,60$ & 61,20 & 67,10 & 96,50 & 104,20 \\
\hline 13. & 72,80 & 71,60 & $-19,30$ & $-21,20$ & 67,40 & 67,10 & 103,90 & 108,40 \\
\hline 14. & 77,00 & 76,90 & $-8,10$ & $-7,80$ & 66,10 & 68,30 & 98,90 & 99,70 \\
\hline 15. & 78,00 & 79,20 & $-7,60$ & $-5,60$ & 67,00 & 74,70 & 100,50 & 111,60 \\
\hline 16. & 74,50 & 75,40 & $-13,40$ & $-11,70$ & 63,10 & 66,90 & 94,50 & 101,50 \\
\hline 17. & 79,50 & 81,00 & $-2,50$ & $-1,50$ & 68,50 & 68,80 & 100,70 & 101,70 \\
\hline 18. & 79,60 & 79,50 & $-4,20$ & $-4,20$ & 62,30 & 65,80 & 92,70 & 101,10 \\
\hline 19. & 75,60 & 77,90 & $-10,10$ & $-8,50$ & 67,10 & 67,90 & 97,10 & 102,90 \\
\hline 20. & 71,90 & 72,20 & $-17,70$ & $-16,70$ & 62,70 & 62,80 & 97,40 & 98,30 \\
\hline 21. & 75,70 & 76,40 & $-10,70$ & $-10,00$ & 66,40 & 70,80 & 103,50 & 110,50 \\
\hline 22. & 74,70 & 76,00 & $-12,50$ & $-10,50$ & 65,20 & 70,10 & 93,10 & 98,60 \\
\hline 23. & 79,90 & 82,40 & $-4,40$ & 0,80 & 61,20 & 71,40 & 94,90 & 106,20 \\
\hline 24. & 79,90 & 78,50 & $-1,00$ & $-3,90$ & 63,20 & 65,40 & 95,50 & 96,60 \\
\hline 25. & 78,20 & 78,40 & $-7,00$ & $-6,40$ & 69,00 & 70,40 & 104,50 & 106,40 \\
\hline 26. & 76,20 & 75,80 & $-12,00$ & $-12,90$ & 64,80 & 69,50 & 97,60 & 100,80 \\
\hline 27. & 75,60 & 74,90 & $-11,10$ & $-11,80$ & 65,70 & 69,40 & 97,90 & 105,10 \\
\hline 28. & 78,40 & 78,50 & $-5,60$ & $-5,30$ & 63,30 & 62,90 & 93,80 & 94,40 \\
\hline 29. & 73,40 & 72,40 & $-14,60$ & $-16,40$ & 67,60 & 68,30 & 98,60 & 101,90 \\
\hline 30. & 70,50 & 71,90 & $-18,00$ & $-15,90$ & 64,10 & 66,30 & 97,00 & 98,10 \\
\hline
\end{tabular}




\section{Apêndice 13}

\section{GRUPO 2- Valores da relação sagital maxilomandibular}

\begin{tabular}{|c|c|c|c|c|}
\hline \multirow[t]{2}{*}{$\mathrm{N}$} & \multicolumn{2}{|c|}{ ANB (graus) } & \multicolumn{2}{|c|}{ NAP (graus) } \\
\hline & Inicial & Final & Inicial & final \\
\hline 1. & 8,30 & 5,00 & 15,00 & 9,30 \\
\hline 2. & 6,30 & 4,30 & 9,70 & 7,00 \\
\hline 3. & 5,40 & 5,10 & 5,50 & 4,90 \\
\hline 4. & 6,60 & 2,40 & 7,80 & $-2,20$ \\
\hline 5. & 3,80 & 3,70 & 4,70 & 4,60 \\
\hline 6. & 10,20 & 6,50 & 18,50 & 11,10 \\
\hline 7. & 10,50 & 6,70 & 20,70 & 11,90 \\
\hline 8. & 4,00 & 2,90 & 7,70 & 5,20 \\
\hline 9. & 5,80 & 4,80 & 9,50 & 6,60 \\
\hline 10. & 6,30 & 2,30 & 9,70 & 0,50 \\
\hline 11. & 7,30 & 4,30 & 12,30 & 5,90 \\
\hline 12. & 4,20 & 3,60 & 8,60 & 6,80 \\
\hline 13. & 7,30 & 6,80 & 15,60 & 13,50 \\
\hline 14. & 5,10 & 5,60 & 9,80 & 9,20 \\
\hline 15. & 4,20 & 1,80 & 7,30 & 2,10 \\
\hline 16. & 4,70 & 3,10 & 10,00 & 4,70 \\
\hline 17. & 4,60 & 2,50 & 6,20 & 3,10 \\
\hline 18. & 7,30 & 4,20 & 13,70 & 6,90 \\
\hline 19. & 8,70 & 5,40 & 16,70 & 11,60 \\
\hline 20. & 4,20 & 2,60 & 7,40 & 3,70 \\
\hline 21. & 4,30 & 1,80 & 7,20 & 0,90 \\
\hline 22. & 4,60 & 2,60 & 9,90 & 4,80 \\
\hline 23. & 5,00 & 0,20 & 9,60 & $-1,60$ \\
\hline 24. & 6,70 & 5,20 & 9,50 & 7,00 \\
\hline 25. & 5,80 & 4,90 & 11,30 & 8,30 \\
\hline 26. & 8,10 & 7,70 & 17,20 & 15,30 \\
\hline 27. & 6,50 & 4,70 & 12,30 & 6,80 \\
\hline 28. & 5,10 & 4,70 & 8,30 & 7,20 \\
\hline 29. & 8,20 & 7,50 & 14,80 & 13,40 \\
\hline 30. & 6,40 & 4,20 & 8,80 & 4,30 \\
\hline
\end{tabular}




\section{Apêndice 14}

\section{GRUPO 2- Valores da relação vertical}

\begin{tabular}{|c|c|c|c|c|c|c|c|c|}
\hline \multirow[t]{2}{*}{$\mathrm{N}$} & \multicolumn{2}{|c|}{ SN.GoGn (graus) } & \multicolumn{2}{|c|}{ SN.PP (graus) } & \multicolumn{2}{|c|}{$\operatorname{AFAl}(\mathrm{mm})$} & \multicolumn{2}{|c|}{ S-GO (mm) } \\
\hline & Inicial & Final & Inicial & Final & Inicial & Final & Inicial & Final \\
\hline 1. & 39,80 & 41,30 & 5,70 & 7,40 & 59,70 & 61,70 & 54,50 & 55,50 \\
\hline 2. & 28,70 & 31,00 & 3,60 & 5,00 & 56,10 & 60,40 & 61,20 & 63,00 \\
\hline 3. & 30,60 & 32,00 & 5,20 & 6,90 & 59,00 & 60,70 & 64,20 & 64,90 \\
\hline 4. & 32,10 & 29,60 & 11,50 & 9,50 & 54,50 & 56,00 & 59,80 & 64,70 \\
\hline 5. & 42,50 & 42,50 & 11,30 & 12,40 & 55,80 & 57,40 & 54,90 & 57,30 \\
\hline 6. & 34,40 & 34,10 & 8,50 & 9,30 & 57,10 & 57,10 & 58,90 & 60,80 \\
\hline 7. & 41,10 & 40,80 & 9,20 & 13,00 & 61,40 & 65,50 & 55,60 & 64,00 \\
\hline 8. & 41,80 & 38,80 & 8,40 & 10,00 & 59,20 & 59,40 & 55,90 & 59,20 \\
\hline 9. & 38,50 & 38,50 & 8,80 & 8,60 & 60,70 & 64,30 & 60,70 & 66,80 \\
\hline 10. & 26,20 & 21,80 & 6,30 & 6,70 & 57,90 & 61,60 & 67,70 & 78,40 \\
\hline 11. & 36,70 & 37,60 & 10,70 & 11,50 & 58,00 & 61,10 & 58,60 & 63,60 \\
\hline 12. & 36,80 & 38,20 & 2,40 & 5,70 & 62,90 & 66,30 & 63,00 & 65,70 \\
\hline 13. & 42,60 & 44,00 & 12,80 & 14,80 & 67,90 & 68,10 & 66,30 & 67,50 \\
\hline 14. & 30,40 & 31,40 & 11,10 & 10,50 & 55,60 & 60,50 & 64,60 & 67,20 \\
\hline 15. & 38,30 & 37,70 & 7,30 & 5,30 & 64,10 & 70,70 & 61,50 & 68,40 \\
\hline 16. & 35,40 & 34,70 & 9,30 & 8,70 & 57,30 & 57,20 & 60,50 & 63,40 \\
\hline 17. & 25,70 & 23,50 & 5,00 & 6,20 & 51,70 & 51,80 & 62,40 & 66,10 \\
\hline 18. & 30,90 & 29,10 & 5,30 & 4,70 & 55,70 & 58,30 & 60,70 & 67,60 \\
\hline 19. & 33,50 & 32,50 & 8,40 & 9,10 & 56,00 & 57,80 & 57,30 & 63,10 \\
\hline 20. & 36,00 & 35,20 & 4,40 & 7,80 & 63,20 & 61,70 & 63,00 & 64,00 \\
\hline 21. & 35,50 & 36,50 & 11,50 & 11,50 & 60,60 & 66,10 & 66,10 & 71,60 \\
\hline 22. & 30,00 & 28,90 & 11,50 & 12,10 & 54,10 & 56,60 & 61,50 & 64,00 \\
\hline 23. & 32,00 & 30,60 & 3,10 & 3,30 & 58,60 & 64,10 & 64,20 & 71,10 \\
\hline 24. & 26,10 & 29,10 & 6,40 & 8,50 & 50,90 & 53,60 & 62,90 & 62,20 \\
\hline 25. & 31,60 & 31,00 & 3,00 & 2,60 & 59,80 & 61,70 & 63,20 & 66,40 \\
\hline 26. & 35,10 & 35,80 & 8,00 & 8,50 & 63,30 & 66,30 & 64,80 & 67,40 \\
\hline 27. & 33,40 & 35,00 & 7,90 & 11,20 & 58,60 & 63,40 & 62,30 & 67,00 \\
\hline 28. & 30,60 & 30,90 & 5,10 & 5,30 & 58,50 & 60,10 & 60,50 & 62,10 \\
\hline 29. & 36,70 & 35,50 & 7,10 & 8,10 & 61,40 & 61,20 & 58,60 & 61,10 \\
\hline 30. & 41,30 & 41,10 & 9,80 & 11,20 & 63,60 & 64,00 & 59,20 & 60,40 \\
\hline
\end{tabular}




\section{Apêndice 15}

\section{GRUPO 2- Valores do componente dentoalveolar superior}

\begin{tabular}{|c|c|c|c|c|c|c|c|c|}
\hline \multirow[t]{2}{*}{$\mathrm{N}$} & \multicolumn{2}{|c|}{ 1.NA (graus) } & \multicolumn{2}{|c|}{$1-\mathrm{NA}(\mathrm{mm})$} & \multicolumn{2}{|c|}{$\underline{6}-\mathrm{PP}(\mathrm{mm})$} & \multicolumn{2}{|c|}{$\underline{6}-\mathrm{FHp}(\mathrm{mm})$} \\
\hline & Inicial & Final & Inicial & Final & Inicial & Final & Inicial & Final \\
\hline 1. & 26,40 & 15,90 & 4,30 & 3,70 & 17,60 & 16,60 & 31,00 & 30,00 \\
\hline 2. & 25,50 & 17,50 & 4,60 & 2,90 & 18,10 & 18,70 & 33,90 & 33,00 \\
\hline 3. & 34,00 & 12,20 & 8,20 & 3,10 & 17,90 & 15,90 & 30,50 & 26,60 \\
\hline 4. & 33,60 & 22,90 & 5,20 & 3,60 & 19,80 & 18,80 & 29,20 & 28,50 \\
\hline 5. & 25,20 & 12,70 & 5,60 & 2,60 & 17,50 & 16,20 & 25,70 & 20,00 \\
\hline 6. & 30,90 & 25,90 & 5,80 & 2,20 & 18,60 & 16,70 & 32,60 & 25,30 \\
\hline 7. & 28,50 & 32,50 & 4,50 & 7,90 & 17,70 & 22,10 & 29,70 & 34,60 \\
\hline 8. & 31,70 & 27,60 & 6,50 & 5,60 & 17,40 & 20,40 & 32,90 & 35,70 \\
\hline 9. & 13,90 & 7,30 & 3,10 & 1,80 & 17,00 & 19,70 & 31,60 & 31,40 \\
\hline 10. & 33,30 & 20,40 & 5,00 & 3,90 & 19,80 & 21,40 & 33,70 & 36,70 \\
\hline 11. & 27,40 & 16,60 & 6,40 & 4,80 & 19,90 & 21,70 & 26,60 & 24,90 \\
\hline 12. & 27,10 & 20,90 & 6,80 & 4,70 & 17,40 & 19,60 & 31,70 & 30,80 \\
\hline 13. & 23,20 & 14,90 & 5,40 & 2,40 & 21,20 & 21,40 & 30,80 & 29,20 \\
\hline 14. & 33,10 & 11,30 & 5,90 & 1,20 & 17,40 & 18,50 & 32,00 & 31,30 \\
\hline 15. & 31,80 & 31,10 & 5,90 & 8,10 & 19,20 & 22,20 & 35,90 & 40,60 \\
\hline 16. & 28,80 & 10,10 & 5,90 & 2,20 & 16,50 & 16,20 & 30,50 & 27,60 \\
\hline 17. & 34,20 & 26,30 & 5,90 & 4,20 & 16,70 & 16,60 & 39,00 & 37,20 \\
\hline 18. & 20,90 & 17,70 & 3,80 & 4,50 & 16,80 & 17,30 & 34,60 & 36,00 \\
\hline 19. & 27,40 & 15,40 & 4,60 & 1,20 & 16,70 & 16,70 & 33,30 & 29,60 \\
\hline 20. & 29,90 & 24,40 & 5,40 & 6,40 & 20,30 & 20,60 & 27,50 & 26,50 \\
\hline 21. & 32,50 & 27,20 & 6,70 & 5,80 & 19,50 & 20,70 & 30,50 & 26,90 \\
\hline 22. & 21,30 & 20,30 & 5,30 & 4,50 & 16,90 & 19,70 & 27,70 & 27,60 \\
\hline 23. & 34,60 & 32,70 & 6,20 & 8,90 & 16,10 & 20,70 & 34,30 & 38,10 \\
\hline 24. & 22,20 & 9,10 & 3,80 & 0,10 & 16,90 & 16,80 & 31,90 & 28,20 \\
\hline 25. & 26,20 & 9,40 & 6,40 & 2,80 & 17,80 & 15,70 & 35,80 & 33,10 \\
\hline 26. & 23,60 & 13,40 & 4,70 & 2,10 & 19,70 & 20,00 & 32,00 & 30,10 \\
\hline 27. & 24,70 & 13,50 & 5,70 & 3,40 & 18,10 & 20,00 & 32,80 & 28,60 \\
\hline 28. & 32,30 & 19,80 & 8,30 & 4,70 & 20,90 & 19,80 & 35,70 & 32,70 \\
\hline 29. & 21,60 & 10,80 & 5,20 & 1,90 & 19,30 & 18,40 & 36,80 & 34,20 \\
\hline 30. & 31,00 & 19,10 & 6,00 & 2,70 & 19,50 & 19,80 & 31,60 & 28,70 \\
\hline
\end{tabular}




\section{Apêndice 16}

GRUPO 2- Valores do componente dentoalveolar inferior

\begin{tabular}{|c|c|c|c|c|c|c|c|c|c|c|}
\hline \multirow[t]{2}{*}{$\mathrm{N}$} & \multicolumn{2}{|c|}{ IMPA (graus) } & \multicolumn{2}{|c|}{ 1.NB (graus) } & \multicolumn{2}{|c|}{$\overline{1}-\mathrm{NB}(\mathrm{mm})$} & \multicolumn{2}{|c|}{$\overline{6}$-GoMe $(\mathrm{mm})$} & \multicolumn{2}{|c|}{$\overline{6}-\mathrm{FHp}(\mathrm{mm})$} \\
\hline & Inicial & Final & Inicial & Final & nicial & Final & Inicial & Final & Inicial & Final \\
\hline 1. & 96,80 & 94,60 & 30,20 & 30,00 & 5,50 & 6,00 & 23,00 & 25,80 & 28,90 & 33,30 \\
\hline 2. & 94,30 & 89,30 & 24,40 & 22,60 & 5,20 & 4,40 & 24,80 & 26,70 & 32,00 & 34,80 \\
\hline 3. & 94,90 & 90,70 & 22,20 & 19,40 & 3,90 & 3,70 & 24,30 & 26,90 & 29,10 & 32,10 \\
\hline 4. & 89,20 & 90,70 & 20,00 & 20,80 & 2,80 & 3,10 & 22,90 & 00 & 28,40 & 31,80 \\
\hline 5. & 93,80 & 91,80 & 25,70 & 23,40 & 3,40 & 4,00 & 21,60 & 23,00 & 26,40 & 27,50 \\
\hline 6. & 98,10 & 100,80 & 25,90 & 28,50 & 5,50 & 5,30 & 24,10 & 26,40 & 30,20 & 30,60 \\
\hline 7. & 96,50 & 99,40 & 32,20 & 35,50 & 7,30 & 7,40 & 26,00 & 28,80 & 29,40 & 34,90 \\
\hline 8. & 89,30 & 88,30 & 25,50 & 23,20 & 5,00 & 4,40 & 25,80 & 90 & 32,60 & 36,10 \\
\hline 9. & 85 & 79,30 & 22,30 & 15,10 & 3,60 & 3,70 & 26,70 & & 31,70 & \\
\hline 10. & 96,00 & 94,60 & 24,50 & 20,90 & 2,60 & 2,40 & 24,80 & & 32,50 & 38,70 \\
\hline 11. & 102,20 & & 34,50 & & & & & & & \\
\hline 12. & 91 & 87,90 & 24,50 & 22,10 & 4,80 & 4,10 & 26,90 & 70 & 31,80 & 33,30 \\
\hline 13. & 94,40 & 86,50 & 31,90 & 24,40 & 8,50 & 7,40 & 29,90 & 30,60 & 30,90 & 32,60 \\
\hline 14. & 106,30 & 94,30 & 36,40 & 25,20 & 6,40 & 4,30 & 27,80 & & 34,70 & 37,30 \\
\hline 15. & 92,50 & 91,40 & 32,10 & 31,30 & 5,60 & 7,60 & 27,60 & & 37,80 & 44,00 \\
\hline 16. & & & & & & 3,20 & & & 31,40 & \\
\hline 17. & 97,50 & 103,00 & 25,50 & 30,20 & 4,10 & 4,10 & 23,50 & & 39,30 & 40,00 \\
\hline 18. & 102,10 & 99,10 & 35,10 & 29,80 & 5,00 & 4,50 & 24,10 & & 35,80 & 39,80 \\
\hline 19. & 99,80 & 90,40 & 32,00 & 23,20 & 4,60 & 3,10 & 24,80 & 27,30 & 32,50 & 36,50 \\
\hline 20. & 92,50 & 93,30 & 22,90 & 23,00 & 4,40 & 4,80 & 25,00 & & 26,90 & 27,90 \\
\hline 21. & & & 31,20 & 25,50 & 5,30 & & 27,50 & & 31,60 & 32,60 \\
\hline 22. & 101,50 & 96,60 & 28,90 & 25,00 & 5,10 & 3,50 & 26,30 & 27,00 & 28,30 & 30,20 \\
\hline 23. & 89,80 & 91,80 & 24,60 & 28,20 & 3,90 & 5,20 & 24,30 & & 33,10 & 42,60 \\
\hline 24. & & 85,40 & 12,80 & 15,60 & 0,80 & 1,60 & 21,40 & & 31,00 & 30,60 \\
\hline 25. & 92,10 & 89,70 & 24,60 & 21,50 & 5,00 & 4,60 & 25,40 & 27,30 & 36,50 & 37,80 \\
\hline 26. & 99,30 & 97,80 & 32,70 & 31,30 & 8,40 & 7,80 & 28,10 & 30,20 & 33,00 & 35,40 \\
\hline 27. & 94,90 & 92,10 & 26,10 & 24,90 & 5,50 & 5,30 & 27,20 & 30,80 & 32,80 & 34,20 \\
\hline 28. & 94,20 & 96,80 & 25,50 & 28,40 & 4,70 & 5,90 & 23,50 & 25,70 & 34,20 & 35,90 \\
\hline 29. & 94,10 & 95,80 & 26,20 & 25,70 & 5,90 & 5,00 & 26,60 & 28,10 & 36,00 & 36,80 \\
\hline 30. & 90,50 & 86,10 & 24,70 & 21,40 & 4,00 & 2,60 & 25,60 & 26,40 & 28,70 & 31,80 \\
\hline
\end{tabular}




\section{Apêndice 17}

GRUPO 2- Valores do perfil tegumentar

\begin{tabular}{|c|c|c|c|c|c|c|}
\hline \multirow[t]{2}{*}{$\mathrm{N}$} & \multicolumn{2}{|c|}{ ANL (graus) } & \multicolumn{2}{|c|}{ Ls-Pog'Sn (mm) } & \multicolumn{2}{|c|}{ Li-Pog'Sn (mm) } \\
\hline & Inicial & Final & Inicial & Final & Inicial & Fina \\
\hline 1. & 103,70 & 119,40 & 7,10 & 4,90 & 3,90 & 3,60 \\
\hline 2. & 109,10 & 102,10 & 5,30 & 5,90 & 3,90 & 4,40 \\
\hline 3. & 113,60 & 123,20 & 2,60 & $-0,10$ & 0,20 & $-1,20$ \\
\hline 4. & 108,40 & 115,90 & 4,80 & 1,60 & 0,10 & 0,30 \\
\hline 5. & 139,90 & 128,10 & 2,10 & 0,10 & 1,50 & 0,30 \\
\hline 6. & 116,10 & 117,30 & 6,20 & 3,30 & 4,20 & 1,60 \\
\hline 7. & 105,90 & 93,40 & 5,30 & 6,80 & 3,50 & 3,40 \\
\hline 8. & 113,10 & 109,10 & 5,00 & 4,20 & 4,10 & 3,80 \\
\hline 9. & 104,80 & 115,20 & 4,40 & 2,90 & 2,50 & 1,60 \\
\hline 10. & 95,80 & 98,80 & 6,80 & 5,20 & $-0,60$ & 0,30 \\
\hline 11. & 90,70 & 92,80 & 7,60 & 6,20 & 3,90 & 3,10 \\
\hline 12. & 119,60 & 124,50 & 4,90 & 3,00 & 5,30 & 3,40 \\
\hline 13. & 106,40 & 104,80 & 7,50 & 7,80 & 5,40 & 5,00 \\
\hline 14. & 92,20 & 103,90 & 6,00 & 4,10 & 4,50 & 2,10 \\
\hline 15. & 98,80 & 98,20 & 8,20 & 7,70 & 6,10 & 5,60 \\
\hline 16. & 118,00 & 113,90 & 4,10 & 3,10 & 3,10 & 0,40 \\
\hline 17. & 115,30 & 121,20 & 4,90 & 3,30 & 1,10 & 1,70 \\
\hline 18. & 112,50 & 117,70 & 5,10 & 3,20 & 5,80 & 3,20 \\
\hline 19. & 135,00 & 124,00 & 3,30 & 2,50 & $-1,70$ & $-0,60$ \\
\hline 20. & 113,90 & 121,30 & 3,20 & 1,40 & 2,60 & 2,00 \\
\hline 21. & 109,80 & 112,50 & 4,50 & 3,00 & 4,20 & 1,80 \\
\hline 22. & 84,40 & 80,80 & 6,90 & 6,00 & 4,90 & 3,80 \\
\hline 23. & 99,00 & 94,30 & 6,70 & 4,90 & 4,60 & 4,40 \\
\hline 24. & 123,60 & 126,10 & 3,90 & 2,70 & 1,00 & $-1,00$ \\
\hline 25. & 111,30 & 118,70 & 6,70 & 4,20 & 4,30 & 2,70 \\
\hline 26. & 102,70 & 100,00 & 7,10 & 6,90 & 8,60 & 9,30 \\
\hline 27. & 130,50 & 130,00 & 4,20 & 1,00 & 3,20 & 2,50 \\
\hline 28. & 111,60 & 135,20 & 5,70 & 1,00 & 4,00 & 1,80 \\
\hline 29. & 110,30 & 109,80 & 6,30 & 5,70 & 5,50 & 6,20 \\
\hline 30. & 109,90 & 110,20 & 5,10 & 4,00 & 3,20 & $-0,40$ \\
\hline
\end{tabular}


Apêndice 18

GRUPO 3- Valores do componente maxilar

\begin{tabular}{|c|c|c|c|c|c|c|}
\hline \multirow[t]{2}{*}{$\mathrm{N}$} & \multicolumn{2}{|c|}{ SNA (graus) } & \multicolumn{2}{|c|}{ Co-A (mm) } & \multicolumn{2}{|c|}{ Nperp-A (mm) } \\
\hline & Inicial & Final & Inicial & Final & Inicial & Final \\
\hline 1. & 79,50 & 80,50 & 73,50 & 74,40 & $-2,90$ & $-2,10$ \\
\hline 2. & 76,50 & 77,30 & 80,80 & 83,00 & $-5,90$ & $-5,30$ \\
\hline 3. & 77,00 & 77,00 & 80,10 & 83,70 & $-5,20$ & $-5,60$ \\
\hline 4. & 85,40 & 83,20 & 83,80 & 84,50 & 2,10 & 0,20 \\
\hline 5. & 79,10 & 79,50 & 80,60 & 82,20 & $-3,40$ & $-3,10$ \\
\hline 6. & 82,40 & 82,10 & 84,60 & 86,70 & $-0,60$ & $-0,90$ \\
\hline 7. & 80,80 & 83,00 & 88,70 & 92,00 & $-2,20$ & 0,00 \\
\hline 8. & 84,40 & 82,30 & 86,00 & 84,90 & 1,20 & $-0,60$ \\
\hline 9. & 76,80 & 76,20 & 83,60 & 84,40 & $-6,10$ & $-7,00$ \\
\hline 10. & 87,10 & 86,80 & 88,60 & 88,00 & 3,80 & 3,70 \\
\hline 11. & 84,60 & 84,00 & 86,40 & 86,90 & 1,50 & 1,00 \\
\hline 12. & 82,10 & 82,10 & 78,60 & 76,90 & $-0,80$ & $-0,80$ \\
\hline 13. & 82,90 & 83,70 & 83,70 & 84,20 & $-0,10$ & 0,70 \\
\hline 14. & 80,00 & 78,80 & 80,70 & 81,70 & $-2,60$ & $-3,80$ \\
\hline 15. & 76,20 & 75,60 & 80,10 & 80,30 & $-6,40$ & $-7,20$ \\
\hline 16. & 89,70 & 87,90 & 92,50 & 98,10 & 6,40 & 5,30 \\
\hline 17. & 80,10 & 77,50 & 80,10 & 84,20 & $-2,90$ & $-6,00$ \\
\hline 18. & 79,80 & 80,00 & 78,30 & 83,80 & $-2,60$ & $-2,50$ \\
\hline 19. & 82,10 & 82,80 & 84,40 & 85,40 & $-0,80$ & $-0,20$ \\
\hline 20. & 87,40 & 86,20 & 82,90 & 84,90 & 3,70 & 2,90 \\
\hline 21. & 79,00 & 78,20 & 80,00 & 79,10 & $-3,60$ & $-4,50$ \\
\hline 22. & 77,60 & 77,40 & 80,00 & 78,70 & $-5,10$ & $-5,40$ \\
\hline 23. & 82,40 & 82,50 & 81,40 & 79,90 & $-0,50$ & $-0,50$ \\
\hline 24. & 75,40 & 74,80 & 80,90 & 79,20 & $-7,10$ & $-8,00$ \\
\hline 25. & 83,10 & 82,20 & 76,80 & 75,90 & 0,10 & $-0,70$ \\
\hline 26. & 81,20 & 80,90 & 82,10 & 82,90 & $-1,60$ & $-1,80$ \\
\hline 27. & 84,40 & 84,10 & 76,50 & 77,60 & 1,20 & 1,00 \\
\hline 28. & 79,60 & 80,70 & 84,20 & 84,40 & $-3,40$ & $-2,30$ \\
\hline 29. & 83,50 & 83,40 & 83,80 & 83,30 & 0,40 & 0,30 \\
\hline 30. & 83,50 & 82,70 & 84,90 & 81,70 & 0,50 & $-0,30$ \\
\hline
\end{tabular}




\section{Apêndice 19}

GRUPO 3- Valores do componente mandibular

\begin{tabular}{|c|c|c|c|c|c|c|c|c|}
\hline \multirow[t]{2}{*}{$\mathrm{N}$} & \multicolumn{2}{|c|}{ SNB (graus) } & \multicolumn{2}{|c|}{ Nperp-P (mm) } & \multicolumn{2}{|c|}{ GO-GN (mm) } & \multicolumn{2}{|c|}{ CO-GN (mm) } \\
\hline & Inicial & Final & Inicial & Final & Inicial & Final & Inicial & Final \\
\hline 1. & 73,10 & 75,60 & $-14,80$ & $-12,20$ & 61,00 & 63,50 & 93,70 & 97,90 \\
\hline 2. & 71,50 & 73,40 & $-19,10$ & $-17,20$ & 58,70 & 63,70 & 94,80 & 103,90 \\
\hline 3. & 72,30 & 73,60 & $-15,00$ & $-13,10$ & 64,00 & 67,20 & 95,60 & 102,40 \\
\hline 4. & 80,80 & 80,80 & 0,10 & 0,00 & 71,70 & 72,50 & 103,50 & 105,80 \\
\hline 5. & 77,30 & 76,30 & $-7,40$ & $-9,70$ & 64,90 & 66,80 & 97,50 & 98,10 \\
\hline 6. & 75,60 & 75,30 & $-13,10$ & $-14,20$ & 69,90 & 69,80 & 102,20 & 105,30 \\
\hline 7. & 74,90 & 77,50 & $-12,90$ & $-8,60$ & 75,40 & 79,80 & 109,40 & 116,40 \\
\hline 8. & 77,90 & 80,00 & $-3,70$ & $-2,70$ & 70,10 & 75,00 & 101,30 & 108,20 \\
\hline 9. & 72,50 & 71,20 & $-18,30$ & $-21,60$ & 64,00 & 65,70 & 104,00 & 102,80 \\
\hline 10. & 83,30 & 84,80 & 2,80 & 5,70 & 81,50 & 80,70 & 112,00 & 115,70 \\
\hline 11. & 76,00 & 78,40 & $-11,60$ & $-8,90$ & 70,10 & 71,60 & 106,90 & 110,30 \\
\hline 12. & 74,20 & 77,50 & $-15,50$ & $-9,50$ & 64,90 & 67,80 & 100,00 & 102,40 \\
\hline 13. & 74,80 & 76,80 & $-14,30$ & $-11,50$ & 60,60 & 63,30 & 98,10 & 100,90 \\
\hline 14. & 75,10 & 76,30 & $-10,60$ & $-9,90$ & 67,30 & 71,50 & 96,80 & 104,20 \\
\hline 15. & 72,20 & 72,80 & $-15,30$ & $-15,40$ & 62,50 & 64,10 & 97,40 & 100,10 \\
\hline 16. & 82,00 & 82,40 & 1,20 & 1,40 & 76,10 & 81,50 & 109,60 & 119,50 \\
\hline 17. & 71,20 & 69,20 & $-19,20$ & $-25,10$ & 65,80 & 68,50 & 98,90 & 105,90 \\
\hline 18. & 74,30 & 74,90 & $-12,10$ & $-11,80$ & 61,80 & 64,60 & 94,60 & 101,00 \\
\hline 19. & 77,00 & 79,30 & $-7,50$ & $-4,50$ & 69,00 & 70,40 & 102,00 & 107,30 \\
\hline 20. & 78,60 & 80,60 & $-6,90$ & $-4,20$ & 63,30 & 67,40 & 93,00 & 100,10 \\
\hline 21. & 75,60 & 76,20 & $-9,60$ & $-9,10$ & 65,00 & 69,10 & 97,20 & 100,40 \\
\hline 22. & 70,60 & 73,30 & $-22,20$ & $-19,50$ & 58,80 & 62,40 & 96,10 & 100,00 \\
\hline 23. & 76,60 & 79,10 & $-9,00$ & $-5,70$ & 68,80 & 69,80 & 102,60 & 107,80 \\
\hline 24. & 71,20 & 71,70 & $-18,00$ & $-19,70$ & 64,50 & 68,10 & 102,80 & 106,50 \\
\hline 25. & 77,70 & 79,20 & $-5,70$ & $-4,00$ & 65,80 & 65,50 & 99,50 & 102,20 \\
\hline 26. & 72,90 & 75,00 & $-17,90$ & $-13,60$ & 64,30 & 66,70 & 98,60 & 100,80 \\
\hline 27. & 76,60 & 78,60 & $-7,70$ & $-4,70$ & 60,30 & 62,20 & 96,00 & 99,50 \\
\hline 28. & 74,10 & 74,80 & $-11,20$ & $-10,80$ & 68,90 & 66,00 & 102,50 & 103,10 \\
\hline 29. & 77,70 & 77,90 & $-7,10$ & $-7,10$ & 65,10 & 65,80 & 100,90 & 101,80 \\
\hline 30. & 76,90 & 78,90 & $-9,90$ & $-7,40$ & 67,10 & 70,00 & 101,90 & 103,50 \\
\hline
\end{tabular}




\section{Apêndice 20}

GRUPO 3- Valores da relação sagital maxilomandibular

\begin{tabular}{|c|c|c|c|c|}
\hline \multirow[t]{2}{*}{$N$} & \multicolumn{2}{|c|}{ ANB (graus) } & \multicolumn{2}{|c|}{ NAP (graus) } \\
\hline & Inicial & Final & Inicial & final \\
\hline 1. & 6,40 & 4,90 & 10,70 & 9,00 \\
\hline 2. & 5,00 & 3,90 & 11,30 & 8,70 \\
\hline 3. & 4,70 & 3,40 & 7,60 & 3,90 \\
\hline 4. & 4,70 & 2,40 & 5,20 & 0,50 \\
\hline 5. & 1,80 & 3,20 & 1,80 & 5,20 \\
\hline 6. & 6,70 & 6,90 & 15,00 & 15,10 \\
\hline 7. & 5,90 & 5,50 & 9,40 & 8,80 \\
\hline 8. & 6,40 & 2,30 & 7,90 & 1,70 \\
\hline 9. & 4,30 & 5,00 & 7,70 & 9,20 \\
\hline 10. & 3,80 & 2,00 & 5,30 & 1,40 \\
\hline 11. & 8,50 & 5,60 & 16,60 & 12,20 \\
\hline 12. & 7,90 & 4,60 & 15,80 & 8,70 \\
\hline 13. & 8,10 & 6,90 & 18,90 & 17,10 \\
\hline 14. & 4,90 & 2,50 & 8,40 & 3,50 \\
\hline 15. & 3,90 & 2,80 & 5,50 & 3,30 \\
\hline 16. & 7,70 & 5,60 & 13,50 & 9,80 \\
\hline 17. & 8,90 & 8,30 & 15,90 & 14,40 \\
\hline 18. & 5,60 & 5,10 & 9,00 & 8,30 \\
\hline 19. & 5,10 & 3,40 & 8,00 & 5,10 \\
\hline 20. & 8,80 & 5,60 & 20,10 & 13,30 \\
\hline 21. & 3,40 & 2,00 & 5,40 & 1,90 \\
\hline 22. & 7,00 & 4,20 & 15,70 & 10,30 \\
\hline 23. & 5,90 & 3,40 & 10,00 & 5,50 \\
\hline 24. & 4,10 & 3,10 & 5,30 & 4,20 \\
\hline 25. & 5,40 & 3,00 & 7,10 & 2,90 \\
\hline 26. & 8,30 & 6,00 & 16,20 & 11,60 \\
\hline 27. & 7,80 & 5,50 & 12,30 & 7,90 \\
\hline 28. & 5,40 & 5,90 & 7,20 & 8,30 \\
\hline 29. & 5,80 & 5,50 & 10,40 & 9,70 \\
\hline 30. & 6,60 & 3,80 & 13,00 & 7,80 \\
\hline
\end{tabular}




\section{Apêndice 21}

\section{GRUPO 3- Valores da relação vertical}

\begin{tabular}{|c|c|c|c|c|c|c|c|c|}
\hline \multirow[t]{2}{*}{$N$} & \multicolumn{2}{|c|}{ SN.GoGn (graus) } & \multicolumn{2}{|c|}{ SN.PP (graus) } & \multicolumn{2}{|c|}{$\operatorname{AFAl}(\mathrm{mm})$} & \multicolumn{2}{|c|}{ S-GO (mm) } \\
\hline & Inicial & Final & Inicial & Final & Inicial & Final & Inicial & Final \\
\hline 1. & 38,60 & 38,90 & 5,80 & 4,40 & 63,20 & 66,20 & 59,40 & 63,30 \\
\hline 2. & 37,40 & 36,90 & 11,00 & 11,10 & 57,90 & 63,30 & 61,40 & 67,00 \\
\hline 3. & 32,40 & 31,40 & 8,80 & 10,80 & 60,20 & 61,00 & 62,40 & 66,30 \\
\hline 4. & 24,80 & 24,90 & 6,00 & 6,80 & 54,70 & 55,90 & 65,80 & 69,00 \\
\hline 5. & 24,60 & 25,90 & 5,80 & 5,10 & 55,30 & 56,40 & 68,90 & 69,00 \\
\hline 6. & 36,90 & 37,00 & 10,30 & 9,20 & 63,10 & 65,80 & 65,50 & 69,20 \\
\hline 7. & 33,90 & 32,60 & 6,80 & 6,70 & 65,10 & 70,40 & 70,70 & 77,30 \\
\hline 8. & 25,80 & 29,30 & 2,10 & 6,90 & 58,80 & 64,20 & 66,00 & 70,40 \\
\hline 9. & 35,60 & 37,60 & 8,00 & 8,40 & 65,70 & 68,50 & 71,70 & 72,20 \\
\hline 10. & 24,00 & 21,90 & 6,50 & 8,00 & 58,40 & 57,50 & 72,80 & 79,20 \\
\hline 11. & 38,00 & 36,30 & 10,70 & 11,60 & 64,70 & 63,90 & 64,20 & 69,10 \\
\hline 12. & 42,10 & 39,20 & 10,60 & 9,50 & 66,60 & 66,70 & 63,10 & 69,20 \\
\hline 13. & 37,70 & 36,10 & 9,60 & 9,80 & 62,40 & 62,50 & 60,80 & 63,90 \\
\hline 14. & 30,00 & 32,60 & 6,60 & 6,50 & 52,60 & 58,70 & 60,90 & 64,60 \\
\hline 15. & 30,30 & 33,40 & 9,20 & 10,50 & 58,10 & 61,50 & 67,10 & 68,60 \\
\hline 16. & 19,60 & 21,10 & 5,10 & 5,50 & 57,80 & 64,10 & 77,80 & 84,70 \\
\hline 17. & 38,70 & 42,60 & 11,40 & 12,80 & 65,60 & 70,70 & 66,60 & 70,30 \\
\hline 18. & 38,00 & 38,40 & 5,90 & 4,80 & 61,30 & 63,80 & 58,30 & 58,80 \\
\hline 19. & 28,20 & 27,60 & 3,00 & 5,40 & 56,50 & 58,40 & 66,30 & 70,10 \\
\hline 20. & 29,20 & 28,50 & 9,40 & 9,60 & 52,20 & 55,10 & 60,20 & 66,40 \\
\hline 21. & 30,30 & 30,30 & 11,70 & 12,00 & 48,40 & 51,70 & 59,50 & 61,70 \\
\hline 22. & 44,50 & 44,10 & 9,90 & 12,00 & 65,60 & 65,30 & 61,30 & 65,30 \\
\hline 23. & 34,10 & 34,40 & 7,40 & 6,50 & 59,80 & 65,10 & 62,00 & 67,90 \\
\hline 24. & 37,50 & 40,50 & 8,90 & 8,70 & 64,00 & 69,70 & 64,90 & 67,10 \\
\hline 25. & 30,30 & 30,20 & 0,90 & 0,70 & 62,50 & 65,80 & 68,70 & 72,90 \\
\hline 26. & 38,30 & 35,30 & 5,40 & 7,20 & 63,30 & 60,40 & 61,40 & 64,00 \\
\hline 27. & 37,40 & 35,60 & 4,50 & 4,60 & 58,80 & 59,40 & 63,30 & 66,10 \\
\hline 28. & 33,80 & 34,20 & 12,10 & 10,90 & 57,90 & 58,80 & 65,60 & 66,50 \\
\hline 29. & 30,30 & 30,30 & 6,90 & 7,80 & 54,80 & 57,80 & 61,70 & 66,30 \\
\hline 30. & 35,20 & 37,00 & 8,00 & 7,80 & 61,10 & 65,50 & 63,70 & 66,60 \\
\hline
\end{tabular}




\section{Apêndice 22}

GRUPO 3- Valores do componente dentoalveolar superior

\begin{tabular}{|c|c|c|c|c|c|c|c|c|}
\hline \multirow[t]{2}{*}{$N$} & \multicolumn{2}{|c|}{ 1.NA (graus) } & \multicolumn{2}{|c|}{ 1-NA $(\mathrm{mm})$} & \multicolumn{2}{|c|}{$\underline{6}-\mathrm{PP}(\mathrm{mm})$} & \multicolumn{2}{|c|}{$\underline{6}-\mathrm{FHp}(\mathrm{mm})$} \\
\hline & Inicial & Final & Inicial & Final & Inicial & Final & Inicial & Final \\
\hline 1. & 19,70 & 12,70 & 4,40 & 3,00 & 17,90 & 18,20 & 28,00 & 29,50 \\
\hline 2. & 24,10 & 20,20 & 6,00 & 5,20 & 17,60 & 19,20 & 33,70 & 31,00 \\
\hline 3. & 25,80 & 23,10 & 5,40 & 5,20 & 19,10 & 21,50 & 28,20 & 29,70 \\
\hline 4. & 27,80 & 26,90 & 3,80 & 4,50 & 18,50 & 19,40 & 37,40 & 36,60 \\
\hline 5. & 28,10 & 31,50 & 6,30 & 5,70 & 17,90 & 17,00 & 36,70 & 35,60 \\
\hline 6. & 11,90 & 7,40 & 1,20 & 1,20 & 19,60 & 20,20 & 33,30 & 33,40 \\
\hline 7. & 31,30 & 15,80 & 8,50 & 4,30 & 21,80 & 24,10 & 35,40 & 38,60 \\
\hline 8. & 27,60 & 24,30 & 4,00 & 5,70 & 18,00 & 21,30 & 34,80 & 33,50 \\
\hline 9. & 35,80 & 21,20 & 6,10 & 4,80 & 21,10 & 20,40 & 31,70 & 31,50 \\
\hline 10. & 24,20 & 21,60 & 8,50 & 8,80 & 22,00 & 21,50 & 44,90 & 44,20 \\
\hline 11. & 21,50 & 23,20 & 4,30 & 5,50 & 20,60 & 22,60 & 31,20 & 33,00 \\
\hline 12. & 28,40 & 27,30 & 6,60 & 6,30 & 22,30 & 22,80 & 35,90 & 37,20 \\
\hline 13. & 25,80 & 22,70 & 6,20 & 4,90 & 20,30 & 20,10 & 31,60 & 32,30 \\
\hline 14. & 42,20 & 37,40 & 9,70 & 10,30 & 18,00 & 19,50 & 33,40 & 36,80 \\
\hline 15. & 26,10 & 31,10 & 6,00 & 5,20 & 19,50 & 18,90 & 31,00 & 31,30 \\
\hline 16. & 15,50 & 15,20 & 2,20 & 1,80 & 21,50 & 25,80 & 44,60 & 46,40 \\
\hline 17. & 23,10 & 12,10 & 5,10 & 3,00 & 21,40 & 22,70 & 34,40 & 30,30 \\
\hline 18. & 29,40 & 24,70 & 5,50 & 3,90 & 16,70 & 17,20 & 28,50 & 29,40 \\
\hline 19. & 30,30 & 22,70 & 7,50 & 5,80 & 17,10 & 19,00 & 36,00 & 36,40 \\
\hline 20. & 11,50 & 16,70 & 1,20 & 3,10 & 17,20 & 18,60 & 37,50 & 37,80 \\
\hline 21. & 34,20 & 24,50 & 6,10 & 5,20 & 15,00 & 16,50 & 31,10 & 31,90 \\
\hline 22. & 32,90 & 24,40 & 7,70 & 6,00 & 18,80 & 19,00 & 29,10 & 29,60 \\
\hline 23. & 25,70 & 23,10 & 5,90 & 5,80 & 20,40 & 23,00 & 34,00 & 34,90 \\
\hline 24. & 29,20 & 19,50 & 7,50 & 4,70 & 22,50 & 22,50 & 30,50 & 27,40 \\
\hline 25. & 23,50 & 24,00 & 3,80 & 4,70 & 20,20 & 21,00 & 33,30 & 34,20 \\
\hline 26. & 28,60 & 24,10 & 6,80 & 6,30 & 17,20 & 16,50 & 33,40 & 32,80 \\
\hline 27. & 27,00 & 17,70 & 5,10 & 3,60 & 17,10 & 16,40 & 36,20 & 36,10 \\
\hline 28. & 23,20 & 13,90 & 3,90 & 1,90 & 19,20 & 18,90 & 34,70 & 33,20 \\
\hline 29. & 18,00 & 17,60 & 4,20 & 3,60 & 17,20 & 17,20 & 36,80 & 35,90 \\
\hline 30. & 34,40 & 25,80 & 6,90 & 5,60 & 20,10 & 21,30 & 34,70 & 34,60 \\
\hline
\end{tabular}




\section{Apêndice 23}

GRUPO 3- Valores do componente dentoalveolar inferior

\begin{tabular}{|c|c|c|c|c|c|c|c|c|c|c|}
\hline \multirow[t]{2}{*}{$\mathrm{N}$} & \multicolumn{2}{|c|}{ IMPA (graus) } & \multicolumn{2}{|c|}{ 1.NB (graus) } & \multicolumn{2}{|c|}{$\overline{1}-\mathrm{NB}(\mathrm{mm})$} & \multicolumn{2}{|c|}{$\overline{6}$-GoMe $(\mathrm{mm})$} & \multicolumn{2}{|c|}{$\overline{6}-\mathrm{FHp}(\mathrm{mm})$} \\
\hline & Inicial & Final & Inicial & Final & Inicial & Final & Inicial & Final & Inicial & Final \\
\hline 1. & 89,20 & 92,80 & 23,90 & 30,20 & 5,00 & 5,80 & 27,20 & 28,60 & 28,10 & 31,60 \\
\hline 2. & 97,90 & 105,50 & 28,80 & 38,00 & 5,00 & 7,20 & 26,50 & 29,00 & 34,00 & 33,10 \\
\hline 3. & 100,60 & 101,20 & 28,40 & 29,60 & 3,60 & 3,60 & 26,20 & 10 & 25,90 & 28,50 \\
\hline 4. & 96,50 & 100,50 & 24,60 & 28,50 & 4,20 & 4,40 & 24,90 & 70 & 37,80 & 39,00 \\
\hline 5. & 106,60 & 114,20 & 30,90 & 38,40 & 5,10 & 6,50 & 27,30 & 28,30 & 39,10 & 40,50 \\
\hline 6. & 92,40 & 92,40 & 27,60 & 27,40 & 5,80 & 5,80 & 28,00 & & 34,40 & 80 \\
\hline 7. & 93,20 & 94,80 & 23,70 & 26,90 & 5,70 & 6,00 & 27,90 & 31,00 & 35,80 & 42,10 \\
\hline 8. & 91 & 99,70 & 17,60 & 30,80 & 2,40 & 5,80 & 26,40 & & 33,70 & 35 \\
\hline 9. & 94 & 99,40 & 25,60 & 30,70 & 6,40 & 6,90 & 30,20 & & & \\
\hline 10. & 98,60 & 101,00 & 28,20 & 29,70 & 6,20 & 6,40 & 26,50 & & 44,90 & 48,10 \\
\hline 11. & & 100,70 & 38,90 & & & & & & & \\
\hline 12. & 98,40 & 94,70 & 37,20 & 33,60 & 8,70 & 9,40 & 27,40 & & 35,10 & 41,50 \\
\hline 13. & 95,80 & 102,30 & 32,40 & 38,80 & 8,60 & 9,10 & 25,70 & & 31,80 & 37,50 \\
\hline 14. & 0 & 100,00 & 23,60 & 30,30 & 3,30 & 4,90 & 21,60 & & 34,30 & 39,10 \\
\hline 15. & 100,30 & 104,70 & 26,80 & 34,80 & 4,70 & 7,20 & 26,60 & & 29,20 & 31,80 \\
\hline 16. & & & & & & & & & & \\
\hline 17. & 102,90 & 102,80 & 34,50 & 36,40 & 8,90 & 9,80 & 29,20 & & 31,30 & 32,90 \\
\hline 18. & 90,80 & 91,40 & 25,60 & 27,20 & 5,10 & 5,40 & 26,00 & & 29,70 & 32,00 \\
\hline 19. & 93,90 & \begin{tabular}{|l|}
97,80 \\
\end{tabular} & 20,70 & 26,60 & 3,90 & 4,60 & 25,50 & 25,90 & 37,00 & 38,30 \\
\hline 20. & 102,80 & 102,50 & 33,00 & 33,80 & 5,50 & 5,90 & 24,20 & & 36,30 & 40,60 \\
\hline 21. & & 95,20 & 19,40 & 24,70 & 2,40 & 3,30 & 22,70 & & & 32,10 \\
\hline 22. & 86,50 & 85,80 & 25,00 & 25,80 & 5,30 & 7,10 & 27,40 & 29,40 & 27,80 & 31,30 \\
\hline 23. & 87,60 & 91,50 & 20,00 & 26,90 & 4,80 & 6,30 & 25,20 & & 33,70 & 39,10 \\
\hline 24. & 81,40 & 87,60 & 12,40 & 21,80 & 3,60 & 6,80 & 25,70 & & 29,50 & 32,00 \\
\hline 25. & 100,00 & 96,60 & 29,90 & 28,50 & 5,50 & 6,10 & 25,30 & 27,80 & 33,70 & 39,90 \\
\hline 26. & 94,40 & 104,40 & 27,20 & 36,50 & 6,10 & 9,00 & 27,50 & 26,80 & 33,70 & 37,50 \\
\hline 27. & 81,20 & 91,90 & 16,70 & 28,10 & 3,30 & 6,00 & 24,60 & 26,50 & 35,50 & 41,30 \\
\hline 28. & 91,60 & 96,00 & 22,20 & 27,90 & 3,30 & 4,20 & 25,60 & 25,90 & 34,00 & 34,60 \\
\hline 29. & 96,30 & 100,20 & 25,90 & 30,40 & 4,40 & 6,40 & 25,30 & 27,90 & 36,60 & 39,70 \\
\hline 30. & 94,10 & 93,10 & 28,10 & 31,10 & 4,80 & 7,20 & 25,40 & 25,40 & 34,10 & 40,60 \\
\hline
\end{tabular}




\section{Apêndice 24}

GRUPO 3- Valores do perfil tegumentar

\begin{tabular}{|c|c|c|c|c|c|c|}
\hline \multirow[t]{2}{*}{$N$} & \multicolumn{2}{|c|}{ ANL (graus) } & \multicolumn{2}{|c|}{ Ls-Pog'Sn (mm) } & \multicolumn{2}{|c|}{ Li-Pog'Sn (mm) } \\
\hline & Inicial & Final & Inicial & Final & Inicial & Final \\
\hline 1. & 108,50 & 109,30 & 7,20 & 6,50 & 5,40 & 6,70 \\
\hline 2. & 122,10 & 120,30 & 5,50 & 4,80 & 7,10 & 6,00 \\
\hline 3. & 113,70 & 112,10 & 5,20 & 4,10 & 3,70 & 1,70 \\
\hline 4. & 132,60 & 122,50 & 0,60 & 1,40 & $-0,40$ & 1,00 \\
\hline 5. & 116,70 & 108,50 & 4,00 & 4,40 & 4,40 & 5,00 \\
\hline 6. & 118,40 & 120,00 & 5,20 & 5,20 & 3,00 & 2,70 \\
\hline 7. & 84,00 & 107,40 & 7,40 & 4,70 & 2,90 & 3,10 \\
\hline 8. & 114,50 & 118,60 & 5,30 & 5,00 & 3,90 & 6,30 \\
\hline 9. & 117,50 & 116,30 & 4,70 & 5,00 & 2,70 & 2,50 \\
\hline 10. & 98,90 & 97,90 & 6,90 & 5,60 & 4,90 & 3,40 \\
\hline 11. & 103,90 & 120,10 & 7,90 & 5,60 & 8,70 & 7,20 \\
\hline 12. & 99,70 & 99,90 & 7,80 & 5,90 & 5,90 & 6,00 \\
\hline 13. & 113,50 & 108,80 & 8,70 & 8,40 & 8,10 & 9,20 \\
\hline 14. & 113,70 & 112,60 & 6,20 & 5,30 & 3,20 & 4,10 \\
\hline 15. & 110,40 & 96,20 & 5,00 & 6,10 & 4,10 & 4,70 \\
\hline 16. & 115,70 & 108,10 & 4,30 & 5,10 & 2,80 & 2,60 \\
\hline 17. & 116,50 & 119,70 & 5,50 & 5,50 & 4,80 & 5,20 \\
\hline 18. & 119,00 & 122,50 & 3,80 & 3,60 & 4,40 & 4,50 \\
\hline 19. & 113,40 & 114,70 & 4,60 & 3,20 & 3,90 & 3,30 \\
\hline 20. & 115,70 & 108,00 & 4,30 & 3,30 & 4,30 & 3,40 \\
\hline 21. & 131,00 & 112,90 & 2,60 & 3,30 & 0,50 & 2,40 \\
\hline 22. & 100,70 & 103,90 & 7,60 & 5,90 & 8,00 & 8,40 \\
\hline 23. & 105,80 & 106,60 & 5,70 & 3,80 & 3,40 & 3,40 \\
\hline 24. & 117,10 & 122,70 & 2,80 & 1,20 & 0,80 & 3,80 \\
\hline 25. & 114,50 & 113,40 & 3,20 & 2,80 & 2,00 & 3,80 \\
\hline 26. & 111,30 & 102,60 & 7,80 & 7,90 & 8,10 & 9,10 \\
\hline 27. & 118,20 & 120,90 & 4,20 & 2,70 & 0,80 & 3,60 \\
\hline 28. & 102,90 & 108,70 & 3,90 & 2,50 & $-1,10$ & $-0,30$ \\
\hline 29. & 102,40 & 102,80 & 5,50 & 5,80 & 3,10 & 3,50 \\
\hline 30. & 111,90 & 120,00 & 6,00 & 4,00 & 5,60 & 4,00 \\
\hline
\end{tabular}




\section{Apêndice 25}

ERRO DO MÉTODO CEFALOMÉTRICO - Valores do componente maxilar

\begin{tabular}{|c|c|c|c|c|c|c|c|c|}
\hline \multirow[t]{2}{*}{$N$} & \multicolumn{2}{|c|}{ SNA (graus) } & \multicolumn{2}{|c|}{ Co-A (mm) } & \multicolumn{2}{|c|}{ Co-ENA(mm) } & \multicolumn{2}{|c|}{ Nperp-A $(\mathrm{mm})$} \\
\hline & $\begin{array}{c}1^{\mathrm{a}} \\
\text { medição }\end{array}$ & $\begin{array}{c}2^{\mathrm{a}} \\
\text { medição }\end{array}$ & $\begin{array}{c}1^{\mathrm{a}} \\
\text { medição }\end{array}$ & $\begin{array}{c}2^{\mathrm{a}} \\
\text { medição }\end{array}$ & $\begin{array}{c}1^{\mathrm{a}} \\
\text { medição }\end{array}$ & $\begin{array}{c}2^{\mathrm{a}} \\
\text { medição }\end{array}$ & $\begin{array}{c}1^{\mathrm{a}} \\
\text { medição }\end{array}$ & $\begin{array}{c}2^{\mathrm{a}} \\
\text { medição }\end{array}$ \\
\hline 1. & 80,00 & 81,10 & 79,20 & 78,60 & 83,40 & 82,30 & $-2,60$ & $-1,60$ \\
\hline 2. & 82,50 & 83,20 & 77,40 & 77,00 & 78,10 & 78,80 & $-0,40$ & 0,20 \\
\hline 3. & 76,00 & 76,10 & 78,00 & 79,30 & 77,60 & 78,30 & $-6,40$ & $-6,40$ \\
\hline 4. & 80,10 & 78,60 & 82,70 & 82,80 & 81,90 & 82,40 & $-3,00$ & $-4,60$ \\
\hline 5. & 82,20 & 81,60 & 82,30 & 82,20 & 82,00 & 82,20 & $-0,70$ & $-1,20$ \\
\hline 6. & 80,50 & 81,00 & 84,00 & 82,40 & 85,00 & 85,90 & $-1,90$ & $-2,40$ \\
\hline 7. & 84,10 & 83,20 & 85,00 & 84,90 & 86,10 & 86,30 & 0,90 & 0,20 \\
\hline 8. & 83,00 & 82,60 & 79,10 & 77,70 & 80,90 & 82,40 & $-0,30$ & 0,00 \\
\hline 9. & 84,00 & 84,10 & 85,50 & 85,70 & 85,90 & 85,80 & 0,90 & 1,00 \\
\hline 10. & 80,70 & 80,50 & 74,30 & 74,40 & 76,40 & 76,00 & $-2,10$ & $-1,90$ \\
\hline 11. & 77,00 & 77,00 & 83,90 & 83,70 & 85,30 & 85,20 & $-5,60$ & $-5,60$ \\
\hline 12. & 83,80 & 83,20 & 84,60 & 84,50 & 86,90 & 86,60 & 0,20 & 0,70 \\
\hline 13. & 87,50 & 86,80 & 88,00 & 88,00 & 88,60 & 88,40 & 3,70 & 4,20 \\
\hline 14. & 89,70 & 90,10 & 92,50 & 92,70 & 95,00 & 94,90 & 6,40 & 6,70 \\
\hline 15. & 82,10 & 82,00 & 84,40 & 84,50 & 86,70 & 86,60 & $-0,80$ & $-0,90$ \\
\hline 16. & 82,10 & 82,20 & 75,90 & 75,90 & 79,30 & 78,30 & $-0,70$ & $-0,80$ \\
\hline 17. & 81,20 & 81,10 & 82,10 & 82,40 & 83,10 & 82,70 & $-1,60$ & $-1,70$ \\
\hline 18. & 79,60 & 79,80 & 84,20 & 84,10 & 86,00 & 86,20 & $-3,40$ & $-3,10$ \\
\hline 19. & 83,50 & 83,70 & 84,90 & 84,90 & 88,50 & 88,30 & 0,50 & 0,70 \\
\hline 20. & 76,80 & 76,20 & 80,40 & 80,40 & 80,80 & 81,30 & $-6,40$ & $-5,80$ \\
\hline
\end{tabular}




\section{Apêndice 26}

\section{ERRO DO MÉTODO CEFALOMÉTRICO - Valores do componente mandibular}

\begin{tabular}{c|c|c|c|c|c|c|c|c}
\hline \multirow{2}{*}{$N$} & \multicolumn{2}{|c|}{ SNB (graus) } & \multicolumn{2}{c|}{ Nperp-P $(\mathrm{mm})$} & \multicolumn{2}{c|}{ GO-GN $(\mathrm{mm})$} & \multicolumn{2}{c}{ CO-GN (mm) } \\
\hline & $\begin{array}{c}1^{\mathrm{a}} \\
\text { medição }\end{array}$ & $\begin{array}{c}2^{\mathrm{a}} \\
\text { medição }\end{array}$ & $\begin{array}{c}1^{\mathrm{a}} \\
\text { medição }\end{array}$ & $\begin{array}{c}2^{\mathrm{a}} \\
\text { medição }\end{array}$ & $\begin{array}{c}1^{\mathrm{a}} \\
\text { medição }\end{array}$ & $\begin{array}{c}2^{\mathrm{a}} \\
\text { medição }\end{array}$ & $\begin{array}{c}1^{\mathrm{a}} \\
\text { medição }\end{array}$ & $2^{\mathrm{a}}$ \\
medição \\
\hline 1. & 74,50 & 75,30 & $-9,30$ & $-8,50$ & 68,00 & 68,20 & 100,10 & 99,20 \\
\hline 2. & 75,90 & 76,70 & $-6,20$ & $-5,60$ & 68,10 & 68,50 & 96,90 & 96,70 \\
\hline 3. & 72,00 & 72,30 & $-17,70$ & $-19,20$ & 64,20 & 65,10 & 95,80 & 98,40 \\
\hline 4. & 72,80 & 71,70 & $-37,00$ & $-21,40$ & 67,40 & 66,20 & 103,90 & 103,80 \\
\hline 5. & 77,00 & 77,50 & $-8,10$ & $-7,00$ & 66,10 & 66,70 & 98,90 & 99,20 \\
\hline 6. & 79,20 & 78,20 & $-5,60$ & $-6,40$ & 74,70 & 74,10 & 111,60 & 111,80 \\
\hline 7. & 79,50 & 79,20 & $-2,50$ & $-3,20$ & 68,50 & 68,30 & 100,70 & 100,90 \\
\hline 8. & 82,40 & 82,40 & 0,80 & 1,00 & 71,40 & 71,20 & 106,20 & 106,80 \\
\hline 9. & 78,20 & 78,30 & $-7,00$ & $-7,00$ & 69,00 & 69,10 & 104,50 & 104,60 \\
\hline 10. & 75,60 & 75,60 & $-12,20$ & $-12,00$ & 63,50 & 63,60 & 97,90 & 98,10 \\
\hline 11. & 73,60 & 73,40 & $-13,10$ & $-13,40$ & 67,20 & 67,10 & 102,40 & 102,40 \\
\hline 12. & 80,80 & 80,90 & 0,00 & 0,20 & 72,50 & 72,80 & 105,80 & 106,10 \\
\hline 13. & 84,80 & 85,10 & 5,70 & 6,20 & 80,70 & 80,90 & 115,70 & 115,60 \\
\hline 14. & 82,00 & 82,00 & 1,20 & 1,30 & 76,10 & 75,80 & 109,60 & 109,80 \\
\hline 15. & 77,00 & 76,50 & $-7,50$ & $-8,10$ & 69,00 & 68,90 & 102,00 & 101,90 \\
\hline 16. & 79,20 & 79,10 & $-4,00$ & $-4,40$ & 65,50 & 65,80 & 102,20 & 102,50 \\
\hline 17. & 72,90 & 72,90 & $-17,90$ & $-18,20$ & 64,30 & 64,30 & 98,60 & 98,70 \\
\hline 18. & 74,10 & 74,30 & $-11,20$ & $-11,30$ & 68,90 & 68,70 & 102,50 & 102,50 \\
\hline 19. & 76,90 & 76,80 & $-9,90$ & $-10,00$ & 67,10 & 67,20 & 101,90 & 101,80 \\
\hline 20. & 73,20 & 73,70 & $-15,80$ & $-14,70$ & 67,00 & 68,20 & 99,20 & 100,40 \\
\hline
\end{tabular}




\section{Apêndice 27}

ERRO DO MÉTODO CEFALOMÉTRICO - Valores da relação sagital maxilomandibular

\begin{tabular}{c|c|c|c|c}
\hline \multirow{2}{*}{$N$} & \multicolumn{2}{|c|}{ ANB (graus) } & \multicolumn{2}{c}{ NAP (graus) } \\
\hline & $1^{\mathrm{a}}$ medição & $2^{\mathrm{a}}$ medição & $1^{\mathrm{a}}$ medição & $2^{\mathrm{a}}$ medição \\
\hline 1. & 5,40 & 5,80 & 5,50 & 6,80 \\
\hline 2. & 6,60 & 6,50 & 7,80 & 8,40 \\
\hline 3. & 4,00 & 3,80 & 7,70 & 7,80 \\
\hline 4. & 7,30 & 6,90 & 15,60 & 14,20 \\
\hline 5. & 5,10 & 4,10 & 9,80 & 6,90 \\
\hline 6. & 1,80 & 2,20 & 2,10 & 1,90 \\
\hline 7. & 4,60 & 4,00 & 6,20 & 5,40 \\
\hline 8. & 0,20 & 0,60 & $-1,60$ & $-1,20$ \\
\hline 9. & 5,80 & 5,80 & 11,30 & 11,50 \\
\hline 10. & 4,90 & 5,20 & 9,00 & 9,20 \\
\hline 11. & 3,40 & 3,60 & 3,90 & 4,20 \\
\hline 12. & 2,40 & 2,90 & 0,50 & 1,40 \\
\hline 13. & 2,00 & 2,30 & 1,40 & 2,00 \\
\hline 14. & 7,70 & 8,10 & 13,50 & 14,20 \\
\hline 15. & 5,10 & 5,50 & 8,00 & 8,40 \\
\hline 16. & 3,00 & 2,90 & 2,90 & 3,10 \\
\hline 17. & 8,30 & 8,20 & 16,20 & 16,40 \\
\hline 18. & 5,40 & 5,60 & 7,20 & 8,00 \\
\hline 19. & 6,60 & 6,90 & 13,00 & 13,40 \\
\hline 20. & 2,90 & 3,00 & 5,20 & 5,10 \\
\hline & & & & \\
\hline
\end{tabular}




\section{Apêndice 28}

Erro do método- Valores da relação vertical

\begin{tabular}{c|c|c|c|c|c|c|c|c}
\hline$N$ & \multicolumn{2}{|c|}{ SN.GoGn (graus) } & \multicolumn{2}{|c|}{ SN.PP (graus) } & \multicolumn{2}{c|}{ AFAI (mm) } & \multicolumn{2}{c}{ S-GO $(\mathrm{mm})$} \\
\hline & $\begin{array}{c}1^{\text {a }} \\
\text { medição }\end{array}$ & $\begin{array}{c}2^{\text {a }} \\
\text { medição }\end{array}$ & $\begin{array}{c}1^{\text {a }} \\
\text { medição }\end{array}$ & $\begin{array}{c}2^{\text {a }} \\
\text { medição }\end{array}$ & $\begin{array}{c}1^{\text {a }} \\
\text { medição }\end{array}$ & $\begin{array}{c}2^{\text {a }} \\
\text { medição }\end{array}$ & $\begin{array}{c}1^{\text {a }} \\
\text { medição }\end{array}$ & $\begin{array}{r}2^{\text {a }} \\
\text { medição }\end{array}$ \\
\hline 1. & 30,60 & 28,90 & 5,20 & 3,90 & 59,00 & 58,70 & 64,20 & 64,50 \\
\hline 2. & 32,10 & 31,20 & 11,50 & 10,80 & 54,50 & 54,60 & 59,80 & 60,40 \\
\hline 3. & 41,80 & 43,50 & 8,40 & 6,20 & 59,20 & 62,00 & 55,90 & 56,20 \\
\hline 4. & 42,60 & 43,70 & 12,80 & 13,70 & 67,90 & 67,00 & 66,30 & 66,20 \\
\hline 5. & 30,40 & 28,30 & 11,10 & 7,60 & 55,60 & 55,50 & 64,60 & 65,00 \\
\hline 6. & 37,70 & 37,00 & 5,30 & 6,30 & 70,70 & 69,50 & 68,40 & 69,20 \\
\hline 7. & 25,70 & 25,90 & 5,00 & 5,30 & 51,70 & 51,60 & 62,40 & 62,60 \\
\hline 8. & 30,60 & 29,60 & 3,30 & 1,80 & 64,10 & 64,50 & 71,10 & 71,40 \\
\hline 9. & 31,60 & 31,50 & 3,00 & 3,00 & 59,80 & 59,80 & 63,20 & 63,30 \\
\hline 10. & 38,90 & 39,40 & 4,40 & 4,70 & 66,20 & 66,40 & 63,30 & 63,60 \\
\hline 11. & 31,40 & 31,50 & 10,80 & 11,30 & 61,00 & 60,80 & 66,30 & 66,40 \\
\hline 12. & 24,90 & 24,50 & 6,80 & 6,90 & 55,90 & 56,30 & 69,00 & 69,70 \\
\hline 13. & 21,90 & 21,20 & 8,00 & 7,60 & 57,50 & 57,60 & 79,20 & 79,60 \\
\hline 14. & 19,60 & 19,60 & 5,10 & 5,30 & 57,80 & 57,50 & 77,80 & 77,70 \\
\hline 15. & 28,20 & 28,70 & 3,00 & 3,50 & 56,50 & 57,10 & 66,30 & 66,10 \\
\hline 16. & 30,20 & 30,30 & 0,70 & 1,30 & 65,80 & 65,40 & 72,90 & 73,10 \\
\hline 17. & 38,30 & 38,00 & 5,40 & 5,30 & 63,30 & 63,10 & 61,40 & 61,50 \\
\hline 18. & 33,80 & 33,90 & 12,10 & 12,10 & 57,90 & 58,20 & 65,60 & 65,70 \\
\hline 19. & 35,20 & 35,80 & 8,00 & 8,10 & 61,10 & 61,60 & 63,70 & 63,30 \\
\hline 20. & 38,80 & 39,40 & 10,00 & 8,30 & 59,40 & 61,00 & 59,20 & 58,80 \\
\hline
\end{tabular}




\section{Apêndice 29}

\section{Erro do método- Valores do componente dentoalveolar superior}

\begin{tabular}{|c|c|c|c|c|c|c|c|c|}
\hline \multirow[t]{2}{*}{$N$} & \multicolumn{2}{|c|}{ 1.NA (graus) } & \multicolumn{2}{|c|}{ 1-NA $(\mathrm{mm})$} & \multicolumn{2}{|c|}{$\underline{6}-\mathrm{PP}(\mathrm{mm})$} & \multicolumn{2}{|c|}{$\underline{6}-\mathrm{FHp}(\mathrm{mm})$} \\
\hline & $\begin{array}{c}1^{\mathrm{a}} \\
\text { medição }\end{array}$ & $\begin{array}{c}2^{\mathrm{a}} \\
\text { medição }\end{array}$ & $\begin{array}{c}1^{\mathrm{a}} \\
\text { medição }\end{array}$ & $\begin{array}{c}2^{\mathrm{a}} \\
\text { medição }\end{array}$ & $\begin{array}{c}1^{\mathrm{a}} \\
\text { medição }\end{array}$ & $\begin{array}{c}2^{\mathrm{a}} \\
\text { medição }\end{array}$ & $\begin{array}{c}1^{\mathrm{a}} \\
\text { medição }\end{array}$ & $\begin{array}{c}2^{\mathrm{a}} \\
\text { medição }\end{array}$ \\
\hline 1. & 34,00 & 33,70 & 8,20 & 8,20 & 17,90 & 17,80 & 30,50 & 31,6 \\
\hline 2. & 33,60 & 32,40 & 5,20 & 5,70 & 19,80 & 19,20 & 29,20 & 29,3 \\
\hline 3. & 31,70 & 29,20 & 6,50 & 6,00 & 17,40 & 18,10 & 32,90 & 32,6 \\
\hline 4. & 23,20 & 26,30 & 5,40 & 6,40 & 21,20 & 20,80 & 30,80 & 32,7 \\
\hline 5. & 33,10 & 34,20 & 5,90 & 6,70 & 17,40 & 15,70 & 32,00 & 33,8 \\
\hline 6. & 31,10 & 31,10 & 8,10 & 7,90 & 22,20 & 22,20 & 35,90 & 33,5 \\
\hline 7. & 34,20 & 35,40 & 5,90 & 5,90 & 16,70 & 16,50 & 39,00 & 40,2 \\
\hline 8. & 32,70 & 32,70 & 8,90 & 8,10 & 20,70 & 20,80 & 34,30 & 37 \\
\hline 9. & 26,20 & 26,30 & 6,40 & 6,50 & 17,80 & 17,70 & 35,80 & 33,6 \\
\hline 10. & 12,70 & 12,80 & 3,00 & 3,00 & 18,20 & 17,90 & 29,50 & 29,8 \\
\hline 11. & 23,10 & 23,50 & 5,20 & 5,30 & 21,50 & 21,50 & 29,70 & 29,8 \\
\hline 12. & 26,90 & 27,70 & 4,50 & 4,00 & 19,40 & 19,40 & 36,60 & 36,7 \\
\hline 13. & 21,60 & 20,80 & 8,80 & 8,40 & 21,50 & 21,60 & 44,20 & 44,3 \\
\hline 14. & 15,50 & 14,80 & 2,20 & 1,90 & 21,50 & 21,40 & 44,60 & 45,7 \\
\hline 15. & 30,30 & 29,60 & 7,50 & 7,30 & 17,10 & 16,90 & 36,00 & 38 \\
\hline 16. & 24,00 & 24,30 & 4,70 & 4,80 & 21,00 & 21,10 & 34,20 & 36 \\
\hline 17. & 28,60 & 29,20 & 6,80 & 6,80 & 17,20 & 17,40 & 33,40 & 34,1 \\
\hline 18. & 23,20 & 23,40 & 3,90 & 3,80 & 19,20 & 18,90 & 35,90 & 34,3 \\
\hline 19. & 34,40 & 34,60 & 6,90 & 7,00 & 20,10 & 20,00 & 34,70 & 36 \\
\hline 20. & 27,60 & 28,60 & 5,60 & 5,70 & 20,40 & 19,90 & 37,30 & 38,20 \\
\hline
\end{tabular}




\section{Apêndice 30}

\section{Erro do método- Valores do componente dentoalveolar inferior}

\begin{tabular}{|c|c|c|c|c|c|c|c|c|c|c|}
\hline \multirow[t]{2}{*}{$\mathrm{N}$} & \multicolumn{2}{|c|}{ IMPA (graus) } & \multicolumn{2}{|c|}{ 1.NB (graus) } & \multicolumn{2}{|c|}{$\overline{1}-\mathrm{NB}(\mathrm{mm})$} & \multicolumn{2}{|c|}{$\overline{6}$-GoMe (mm) } & \multicolumn{2}{|c|}{$\overline{6}-\mathrm{FHp}(\mathrm{mm})$} \\
\hline & $\begin{array}{c}1^{\mathrm{a}} \\
\text { medição }\end{array}$ & $\begin{array}{c}2^{\mathrm{a}} \\
\text { medição }\end{array}$ & $\begin{array}{c}1^{\mathrm{a}} \\
\text { medição }\end{array}$ & $\begin{array}{c}2^{\mathrm{a}} \\
\text { medição }\end{array}$ & \begin{tabular}{|c|}
$1^{\mathrm{a}}$ \\
medição
\end{tabular} & $\begin{array}{c}2^{\mathrm{a}} \\
\text { medição }\end{array}$ & $\begin{array}{c}1^{\mathrm{a}} \\
\text { medição }\end{array}$ & $\begin{array}{c}2^{\mathrm{a}} \\
\text { medição }\end{array}$ & $\begin{array}{c}1^{\mathrm{a}} \\
\text { medição }\end{array}$ & $\begin{array}{c}2^{\mathrm{a}} \\
\text { medição }\end{array}$ \\
\hline 1. & 94,90 & 95,30 & 22,20 & 21,90 & 3,90 & 3,90 & 24,30 & 24,80 & 29,10 & 30,4 \\
\hline 2. & 89,20 & 91,20 & 20,00 & 21,50 & 2,80 & 3,00 & 22,90 & 23,50 & 28,40 & 28,5 \\
\hline 3. & 89,30 & 86,40 & 25,50 & 24,40 & 5,00 & 4,70 & 25,80 & 26,00 & 32,60 & 33,8 \\
\hline 4. & 94,40 & 94,70 & 31,90 & 31,80 & 8,50 & 9,00 & 29,90 & 29,40 & 30,90 & 32,7 \\
\hline 5. & 106,30 & 109,50 & 36,40 & 38,20 & 6,40 & 6,10 & 27,80 & 28,50 & 34,70 & 35,3 \\
\hline 6. & 91,40 & 92,20 & 31,30 & 30,30 & 7,60 & 7,80 & 30,70 & 30,90 & 37,80 & 36,3 \\
\hline 7. & 97,50 & 97,70 & 25,50 & 25,40 & 4,10 & 4,00 & 23,50 & 23,10 & 39,30 & 40,8 \\
\hline 8. & 91,80 & 91,50 & 28,20 & 26,80 & 5,20 & 4,80 & 28,20 & 28,10 & 33,10 & 34,8 \\
\hline 9. & 92,10 & 91,80 & 24,60 & 24,20 & 5,00 & 5,00 & 25,40 & 25,80 & 36,50 & 36,7 \\
\hline 10. & 92,80 & 91,90 & 30,20 & 29,50 & 5,80 & 6,00 & 28,60 & 28,70 & 31,60 & 31,5 \\
\hline 11. & 101,20 & 101,20 & 29,60 & 29,40 & 3,60 & 3,80 & 26,10 & 26,50 & 28,50 & 28,5 \\
\hline 12. & 100,50 & 101,30 & 28,50 & 29,20 & 4,40 & 4,00 & 25,70 & 26,60 & 39,00 & 38,9 \\
\hline 13. & 101,00 & 100,70 & 29,70 & 29,00 & 6,40 & 6,30 & 28,20 & 28,10 & 48,10 & 48,5 \\
\hline 14. & 110,50 & 110,90 & 33,90 & 34,10 & 5,10 & 5,20 & 27,00 & 26,60 & 45,10 & 43,8 \\
\hline 15. & 93,90 & 93,90 & 20,70 & \begin{tabular}{|l|}
20,90 \\
\end{tabular} & 3,90 & 4,30 & 25,50 & 25,70 & 37,00 & 34,8 \\
\hline 16. & 96,60 & 95,50 & 28,50 & 27,30 & 6,10 & 6,50 & 27,80 & 28,10 & 39,90 & 41,6 \\
\hline 17. & 94,40 & 95,00 & 27,20 & 27,80 & 6,10 & 6,20 & 27,50 & 27,50 & 33,70 & 35,9 \\
\hline 18. & 91,60 & 90,90 & 22,20 & 21,90 & 3,30 & 3,30 & 25,60 & 25,70 & 33,80 & 34,3 \\
\hline 19. & 94,10 & 93,70 & 28,10 & 28,40 & 4,80 & 4,90 & 25,40 & 26,20 & 34,10 & 34,5 \\
\hline 20. & 88,30 & 87,20 & 23,20 & 23,60 & 4,40 & 4,40 & 25,90 & 26,10 & 32,50 & 33,80 \\
\hline
\end{tabular}




\section{Apêndice 31}

\section{Erro do método- Valores do perfil tegumentar}

\begin{tabular}{c|c|c|c|c|c|c}
\hline \multirow{2}{*}{$N$} & \multicolumn{2}{|c|}{ ANL (graus) } & \multicolumn{2}{c|}{ Ls-Pog'Sn (mm) } & \multicolumn{2}{c}{ Li-Pog'Sn (mm) } \\
\hline & $1^{\mathrm{a}}$ medição & $2^{\mathrm{a}}$ medição & $1^{\mathrm{a}}$ medição & $2^{\mathrm{a}}$ medição & $1^{\text {a }}$ medição & $2^{\mathrm{a}}$ medição \\
\hline 1. & 113,60 & 104,90 & 2,60 & 3,30 & 0,20 & 0,20 \\
\hline 2. & 108,40 & 104,20 & 4,80 & 5,20 & 0,10 & 0,30 \\
\hline 3. & 113,10 & 113,80 & 5,00 & 5,10 & 4,10 & 4,50 \\
\hline 4. & 106,40 & 102,70 & 7,50 & 7,50 & 5,40 & 5,80 \\
\hline 5. & 92,20 & 97,50 & 6,00 & 5,40 & 4,50 & 5,20 \\
\hline 6. & 98,20 & 117,30 & 7,70 & 5,90 & 5,60 & 4,30 \\
\hline 7. & 115,30 & 106,20 & 4,90 & 5,40 & 1,10 & 1,40 \\
\hline 8. & 94,30 & 94,40 & 4,90 & 5,60 & 4,40 & 5,10 \\
\hline 9. & 111,30 & 112,90 & 6,70 & 6,50 & 4,30 & 4,30 \\
\hline 10. & 109,30 & 110,60 & 6,50 & 6,30 & 6,70 & 6,80 \\
\hline 11. & 112,10 & 111,00 & 4,10 & 4,00 & 1,70 & 2,00 \\
\hline 12. & 122,50 & 120,70 & 1,40 & 1,60 & 1,00 & 1,30 \\
\hline 13. & 97,90 & 99,20 & 5,60 & 5,30 & 3,40 & 3,30 \\
\hline 14. & 115,70 & 115,70 & 4,30 & 4,40 & 2,80 & 2,60 \\
\hline 15. & 113,40 & 111,50 & 4,60 & 4,80 & 3,90 & 3,90 \\
\hline 16. & 113,40 & 114,00 & 2,80 & 3,00 & 3,80 & 3,90 \\
\hline 17. & 111,30 & 115,20 & 7,80 & 7,60 & 8,10 & 8,20 \\
\hline 18. & 102,90 & 101,80 & 3,90 & 3,90 & $-1,10$ & $-1,00$ \\
\hline 19. & 111,90 & 112,20 & 6,00 & 6,00 & 5,60 & 5,50 \\
\hline 20. & 109,10 & 106,70 & 4,20 & 4,70 & 3,80 & 3,70 \\
\hline
\end{tabular}




\section{Apêndice 32}

\section{Média das medidas finais dos 3 grupos}

\begin{tabular}{|c|c|c|c|}
\hline \multirow{2}{*}{$\begin{array}{l}\text { GRANDEZAS } \\
\text { CEFALOMÉTRICAS }\end{array}$} & \multicolumn{3}{|c|}{ MÉDIAS DAS MEDIDAS FINAIS } \\
\hline & GRUPO 1 & GRUPO 2 & GRUPO 3 \\
\hline \multicolumn{4}{|l|}{ Maxilares } \\
\hline SNA & 79,95 & 79,89 & 81,11 \\
\hline Nperp-A & $-2,98$ & $-2,85$ & $-1,78$ \\
\hline Co-A & 83,35 & 80,55 & 83,09 \\
\hline \multicolumn{4}{|l|}{ Mandibulares } \\
\hline SNB & 75,18 & 75,65 & 76,71 \\
\hline Nperp-P & $-11,51$ & $-10,79$ & $-9,82$ \\
\hline Go-Gn & 68,13 & 67,84 & 68,70 \\
\hline Co-Gn & 102,48 & 102,25 & 104,46 \\
\hline \multicolumn{4}{|l|}{ Maxilomandibular } \\
\hline ANB & 4,62 & 4,23 & 4,41 \\
\hline NAP & 7,77 & 6,42 & 7,64 \\
\hline \multicolumn{4}{|l|}{ Verticais } \\
\hline SN.GoGn & 32,00 & 34,29 & 33,47 \\
\hline SN.PP & 8,44 & 8,51 & 8,05 \\
\hline AFAl & 60,21 & 61,15 & 62,47 \\
\hline S-Go & 66,95 & 64,81 & 68,43 \\
\hline \multicolumn{4}{|l|}{ Dentárias superiores } \\
\hline 1.NA & 25,57 & 18,63 & 21,74 \\
\hline 1-NA & 5,21 & 3,80 & 4,85 \\
\hline$\underline{6}-\mathrm{FHp}$ & 33,78 & 30,79 & 34,17 \\
\hline$\underline{6}-\mathrm{PP}$ & 19,45 & 18,96 & 20,07 \\
\hline \multicolumn{4}{|l|}{ Dentárias inferiores } \\
\hline$\overline{1 . N B}$ & 25,15 & 24,87 & 30,67 \\
\hline$\overline{1-N B}$ & 4,66 & 4,66 & 6,32 \\
\hline$\overline{6}-\mathrm{FHp}$ & 33,95 & 34,45 & 37,18 \\
\hline$\overline{6-G o M e}$ & 26,84 & 27,11 & 27,79 \\
\hline IMPA & 95,72 & 92,36 & 98,17 \\
\hline \multicolumn{4}{|l|}{ Tegumentares } \\
\hline ANL & 118,18 & 112,08 & 111,93 \\
\hline Ls-Pog'Sn & 3,79 & 3,88 & 4,62 \\
\hline Li-Pog'Sn & 2,65 & 2,50 & 4,34 \\
\hline
\end{tabular}




\section{Universidade de São Paulo Faculdade de Odontologia de Bauru}

Al. Dr, Octávio Pinheiro Brisolla, 9-75 - Bauru-SP - CEP 17012-901 - C.P. 73 PABX (0XX14)235-8000 - FAX (0XX14)223-4679

Comilê de Éfica em Pesquisa

\section{Processo $n^{\circ} 108 / 2002$}

Bauru, 26 de setembro de 2002

Senhor Professor,

O projeto de pesquisa encaminhado a este Comitê de Ética em Pesquisa em Seres Humanos, denominado "Avaliação cefalométrica comparativa entre o aparelho extrabucal conjugado e o bionator de Balters, no tratamento da má oclusão de classe $\|$, $1^{2}$ divisăo" de autoria de Renata Rodrigues de Almeida Pedrin, sob a sua orientação foi enviado ao relator para avaliação.

Na reunião de 25 de setembro, o parecer do Relator aprovando o projeto, foi aceito pelo Comitê, considerando que nāo existem infraçōes éticas pendentes.

Informamos que após o envio do trabalho concluido, este Comitè enviará o parecer final, que será utilizado para publicaçảo do trabalho.

Atenciosamente,

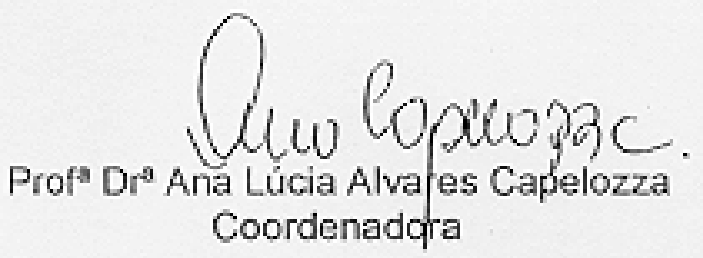

$11 \mathrm{~m}^{\circ} \mathrm{Sr}$, Prof, Dr, Arnaldo Pinzan

DD. Docente do Departamento de Odontopediatria, Ortodontia e Saúde Coletiva 